\title{
Annual Report to Congress on Federal Government Energy Management and Conservation Programs Fiscal Year 1998
}

\section{March 20, 2000}

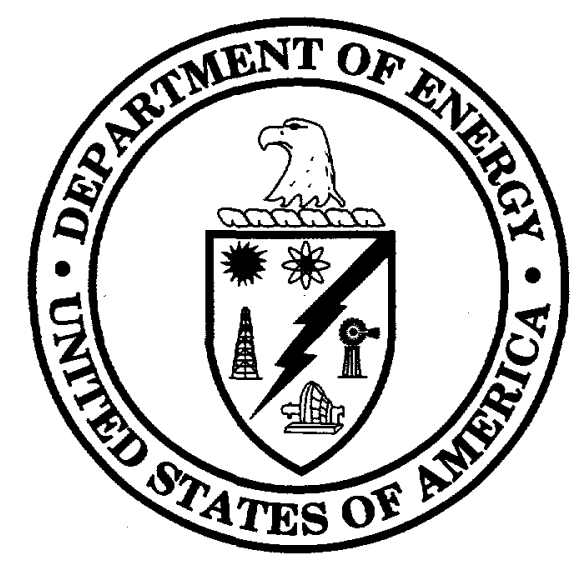

\section{U.S. Department of Energy}

Assistant Secretary, Energy Efficiency and Renewable Energy Federal Energy Management Program Washington, DC 20585 


\section{DISCLAIMER}

This report was prepared as an account of work sponsored by an agency of the United States Government. Neither the United States Government nor any agency thereof, nor any of their employees, make any warranty, express or implied, or assumes any legal liability or responsibility for the accuracy, completeness, or usefulness of any information, apparatus, product, or process disclosed, or represents that its use would not infringe privately owned rights. Reference herein to any specific commercial product, process, or service by trade name, trademark, manufacturer, or otherwise does not necessarily constitute or imply its endorsement, recommendation, or favoring by the United States Government or any agency thereof. The views and opinions of authors expressed herein do not necessarily state or reflect those of the United States Government or any agency thereof. 


\section{DISCLAIMER}

Portions of this document may be illegible in electronic image products. Images are produced from the best available original document. 


\section{TABLE OF CONTENTS}

EXECUTIVE SUMMARY $\ldots \ldots \ldots \ldots \ldots \ldots \ldots \ldots \ldots \ldots \ldots \ldots \ldots \ldots \ldots$

I. OVERVIEW OF FEDERAL ENERGY MANAGEMENT ACTIVITIES . .7

A. Overview of Federal Energy Management Policy and

Legislative Mandates .......................... 7

B. Overall Federal Energy Consumption, Costs, and Carbon Emissions . . . 10

C. Federal Coordination ......................... 17

D. Personnel and Energy Awareness Activities ............... 20

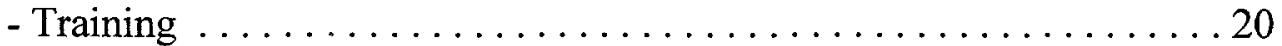

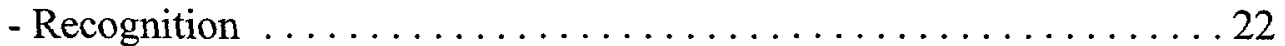

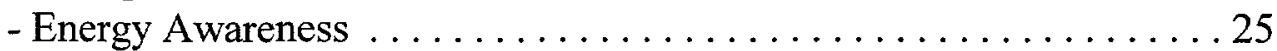

- Federal Energy Saver Showcase Facilities $\ldots \ldots \ldots \ldots \ldots \ldots . . .26$

E. Funding for Energy Efficiency in Buildings and Facilities .........27

- Direct Appropriations ............................27

- Federal Energy Efficiency Fund $\ldots \ldots \ldots \ldots \ldots \ldots \ldots \ldots \ldots \ldots$

- Energy Savings Performance Contracting ................... 33

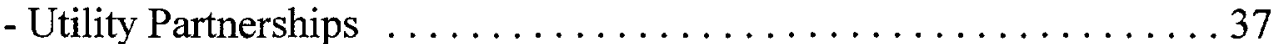

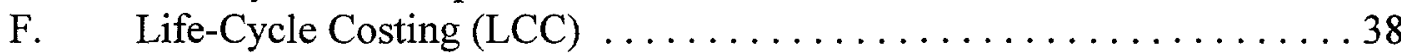

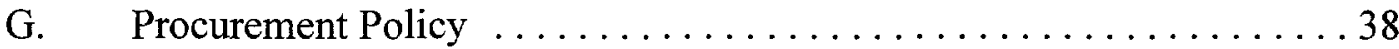

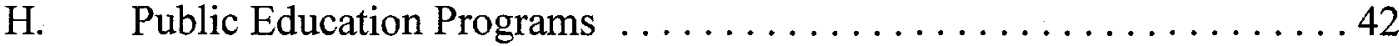

II. ENERGY MANAGEMENT IN BUILDINGS AND FACILITIES . . . . . 46

A. Energy Consumption and Costs for Buildings and Facilities .......46

B. Progress Toward the Mandated Goals for Buildings and Facilities . . . . 54

C. ENERgY STAR ${ }^{\circledR}$ Program Participation ..................... 59

D. Federal Building Energy Performance Standards $\ldots \ldots \ldots \ldots \ldots 61$

III. ENERGY INTENSIVE OPERATIONS IN FEDERAL FACILITIES $\ldots .63$

A. Energy Consumption and Costs for Energy Intensive Operations . . . . 63

B. Statutory Background and Progress Toward Goals

for Industrial Facilities . . . . . . . . . . . . . . . . . . . 65

IV. ENERGY MANAGEMENT IN VEHICLES AND EQUIPMENT . . . . . 69

A. Energy Consumption and Costs for Vehicles and Equipment .......69 69

B. Alternative Fuel Vehicles ......................... 74

V. FEDERAL AGENCY ENERGY MANAGEMENT ACTIVITIES $\ldots \ldots 77$

1. Department of Agriculture . . . . . . . . . . . . . . . . . 77

2. Department of Commerce ........................... 79

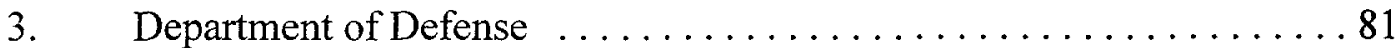

4. Department of Energy ............................ 87

5. Department of Health and Human Services ................ 94

6. Department of Housing and Urban Development ............ 97

7. Department of the Interior ......................... 99 


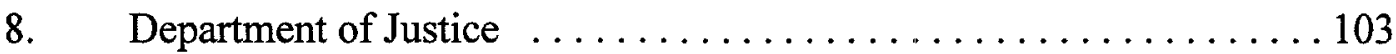

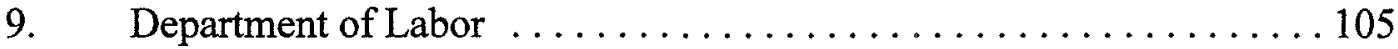

10. Department of State ................................. 107

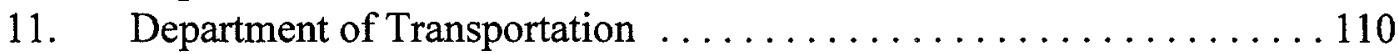

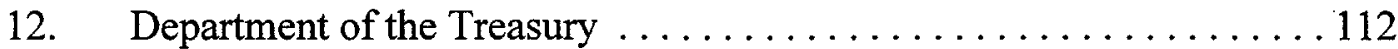

13. Department of Veterans Affairs ........................ 114

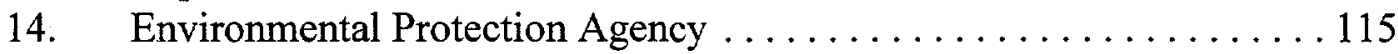

15. General Services Administration ...................... 118

16. National Aeronautics and Space Administration ............. 121

17. National Archives and Records Administration ............. 126

18. Nuclear Regulatory Commission . . . . . . . . . . . . . . 127

19. Railroad Retirement Board ........................ 128

20. Social Security Administration . . . . . . . . . . . . . . . . . . 129

21. Tennessee Valley Authority . . . . . . . . . . . . . . . 131

22. United States Postal Service $\ldots \ldots \ldots \ldots \ldots \ldots \ldots \ldots \ldots \ldots \ldots \ldots \ldots$

TABLES

Table 1-A

Table 1-B

Table 2

Table 3-A

Table 3-B

Table 4-A

Table 4-B

Table 5

Table 6-A

Table 6-B

Table 7-A

Table 7-B

Table 8

Table 9

Table 10

Table 11-A

Total Primary Energy Consumption By Federal Agencies $\ldots \ldots \ldots \ldots 11$

Total Net Energy Consumption By Federal Agencies ............. 12

Federal Petroleum Usage in FY 1998 . . . . . . . . . . . . . . . 15

Agency Expenditures for Energy Conservation Retrofits and Capital

Equipment, FY 1985 through FY 1998

(Thousands of Nominal Dollars) . .................... 28

Agency Expenditures for Energy Conservation Retrofits and Capital

Equipment, FY 1985 through FY 1998

(Thousands of Constant 1998 Dollars) ..................29

Federal Primary Energy Consumption in Buildings and Facilities . . . . 47

Federal Net Energy Consumption in Buildings and Facilities ....... 48

Petroleum-Based Fuel Consumption in Buildings and Facilities ..... 51

Defense and Civilian Federal Costs for Buildings Energy in FY 1998 . . 52

Consumption and Costs of Federal Buildings Energy

by Fuel Type in FY 1998, FY 1997, and FY $1985 \ldots \ldots \ldots \ldots . \ldots 53$

Federal Buildings and Facilities Net Energy Use

Per Gross Square Foot, FY 1985 and FY 1998 .............. 56

Federal Buildings and Facilities Primary Energy Use

Per Gross Square Foot, FY 1985 and FY 1998 ............. 57

Federal Net Energy Consumption in Excluded Buildings/

Process Operations . . . . . . . . . . . . . . . . . . . . . . . . . . 64

Defense and Civilian Federal Costs for Excluded Buildings/

Process Energy in FY 1998 . . . . . . . . . . . . . . . . . . . 66

Federal Energy Consumption in Vehicle and Equipment Operations . . 70

Defense and Civilian Federal Costs for Vehicle and Equipment

Energy in FY 1998 . . . . . . . . . . . . . . . . . . . . . . 72 
Table 11-B Consumption and Costs of Vehicle and Equipment Energy

by Fuel Type in FY 1998, FY 1997, and FY 1985 ........... 73

Table 12 Federal Agency Consumption of Alternative Fuels in

Non-Tactical Vehicles, FY 1998 . . . . . . . . . . . . . . . . . . . . . 75

Table C Federal Energy Expenditures, FY 1985 through FY 1998 . . . . . . . . C-2

\section{FIGURES}

Figure ES-1 Decrease in Btu per Gross Square Foot in Federal

Buildings and Facilities from FY $1985 \ldots \ldots \ldots \ldots \ldots \ldots . \ldots$

Figure ES-2 Federal Consumption of Petroleum-Based Fuels

FY 1985 through FY $1998 \ldots \ldots \ldots \ldots \ldots \ldots \ldots \ldots \ldots \ldots$

Figure $1 \quad$ Federal Energy Consumption, FY $1998 \ldots \ldots \ldots \ldots \ldots \ldots \ldots \ldots$

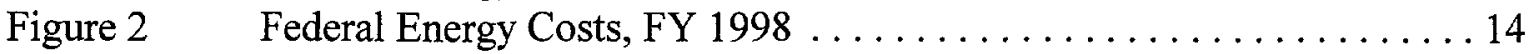

Figure 3 Carbon Emissions from Federal Energy Consumption,

FY 1990 to FY 1998 . . . . . . . . . . . . . . . . . . . . . . . . . 16

Figure 4 Energy Conservation Retrofit Expenditures $\ldots \ldots \ldots \ldots \ldots \ldots \ldots$

Figure 5 Defense and Civilian Energy Consumption

in Buildings and Facilities by Fuel Type, FY 1998 . .......... 46

Figure 6 Consumption of Electricity and Other Fuels

in Buildings and Facilities, FY 1985 through FY 1998 . . . . . . . . . 49

Figure 7 Energy Costs (Constant 1998 Dollars) in Buildings

and Facilities, FY 1985 through FY $1998 \ldots \ldots \ldots \ldots \ldots \ldots . \ldots 50$

Figure 8 Progress Toward the Energy Reduction Goals for Federal

Buildings and Facilities, FY 1985 through FY 1998 ........... 54

Figure 9 Range of Energy Intensity (Btu/GSF) in Buildings and Facilities

by Agency in FY 1998 . . . . . . . . . . . . . . . . . . . . . . 59

Figure 10 Defense and Civilian Federal Energy Consumption

in Vehicles and Equipment by Fuel Type, FY 1998 ............ 71

\section{APPENDICES}

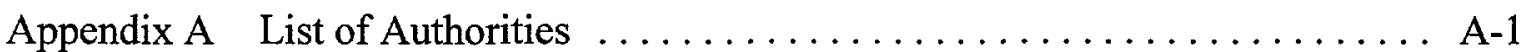

Appendix B Data Collection . ............................ B-1

Appendix C Federal Energy Expenditures FY 1985 through FY 1998 . . . . . . . C-1

Appendix D Buildings Exempted From NECPA's Performance Goal in FY 1998 . D-1

Appendix E Department of Energy: Education, Extension, and

Information Services ......................... E-1

Appendix F Federal Interagency Energy Policy Committee .............. F-1

Appendix G Personnel of the Department of Energy's Federal

Energy Management Program $\ldots \ldots \ldots \ldots \ldots \ldots \ldots$ G-1 


\section{AGENCY ACRONYMS}

Commodity Futures Trading Commission

Central Intelligence Agency

CFTC

Department of Agriculture

CIA

Department of Commerce

USDA

Department of Defense

DOC

Department of Energy

DOD

Department of Health and Human Services

DOE

HHS

Department of Housing and Urban Development

Department of the Interior

HUD

Department of Justice

DOI

Department of Labor

DOJ

Department of State

DOL

ST

Department of Transportation

DOT

Department of the Treasury

TRSY

Department of Veterans Affairs VA

Environmental Protection Agency EPA

Equal Employment Opportunity Commission EEOC

Federal Communications Commission $\quad$ FCC

Federal Emergency Management Agency FEMA

Federal Energy Regulatory Commission FERC

Federal Trade Commission $\quad$ FTC

General Services Administration GSA

National Aeronautics and Space Administration NASA

National Archives and Records Administration NARA

National Science Foundation NSF

Nuclear Regulatory Commission NRC

Office of Personnel Management OPM

Panama Canal Commission PCC

Railroad Retirement Board RRB

Social Security Administration SSA

Tennessee Valley Authority TVA

United States Information Agency USIA

United States Postal Service USPS

\section{INTERNET WEB SITES CITED IN THIS REPORT}

Federal Energy Management Program

Energy Efficiency and Renewable

Energy Clearinghouse

National Energy Information Center

Alternative Fuels Data Center

Clean Cities Program www.eren.doe.gov/femp

www.eren.doe.gov

www.eia.doe.gov

www.afdc.nrel.gov

www.ccities.doe.gov 


\section{EXECUTIVE SUMMARY}

This report on Federal Energy Management for Fiscal Year (FY) 1998 provides information on energy consumption in Federal buildings, operations, and vehicles and equipment, and documents activities conducted by Federal agencies to meet the statutory requirements of Title V, Part 3, of the National Energy Conservation Policy Act (NECPA), as amended, 42 U.S.C. $\S \S$ 8251-8259, 8262, 8262b-k, and Title VIII of NECPA, 42 U.S.C. $\$ 8287-8287$ c. Implementation activities undertaken during FY 1998 by the Federal agencies under the Energy Policy Act of 1992 (EPACT) and Executive Order 12902, Energy Efficiency and Water Conservation at Federal Facilities, are also discussed in this report.

Based on reports submitted to the Department of Energy (DOE) by 29 Federal agencies, the total primary energy consumption of the Government of the United States, including energy consumed to produce, process, and transport energy, was 1.49 quadrillion British Thermal Units (quads) during FY 1998. ${ }^{1}$ These 1.49 quads consumed by the Government in buildings and operations to provide essential services to its citizens, including the defense of the Nation, represent approximately 1.6 percent of the total 94.23 quads $^{2}$ used in the United States. In total, the Federal Government is the single largest energy consumer in the Nation, although its pattern of consumption is widely dispersed.

The Government consumed 1.04 quads during FY 1998 when measured in terms of energy actually delivered to the point of use (net energy consumption). Unless otherwise noted, this report uses the site-measured conversion factors to convert common units for electricity and steam to British Thermal Units (Btu). The total net energy consumption in FY 1998 decreased 27.8 percent from the FY 1985 base year. This reduction of 401.8 trillion Btu could satisfy the energy needs of the State of Idaho for more than one year. ${ }^{3}$

The total cost of the 1.04 quads was almost $\$ 8.5$ billion in FY $1998 .^{4}$ This is $\$ 2.0$ billion less than the $\$ 10.5$ billion reported in FY 1985 , an 18.8 percent $^{5}$ decrease in nominal costs. In

\footnotetext{
${ }^{1}$ Primary energy consumption considers all energy resources used to generate and transport electricity and steam. Tables 1-A, 4-A, and 7-B show primary energy consumption for comparison with net consumption, Tables 1-B, 4-B, and 7-A respectively. Conversion factors of 11,600 Btu per kilowatt hour for electricity and 1,390 Btu per pound of steam are used to calculate gross energy consumption.

${ }^{2}$ DOE/EIA-0384(98), Annual Energy Review 1998, July 1999.

${ }^{3}$ Based on net energy consumption estimates for 1994 in the residential, commercial, industrial, and transportation sectors (362.4 trillion Btu). Source: DOE/EIA-0214(96), State Energy Data Report, 1996, Tables 1 and 8; February 1999.

${ }^{4}$ Unless otherwise noted, all costs cited in this report are in constant 1998 dollars, calculated using Gross Domestic Product implicit price deflators. See DOE/EIA-0384(98), Annual Energy Review 1998, Table E1; July 1999. Costs noted as nominal dollars reflect the price paid at the time of the transaction and have not been adjusted to remove the effect of changes in the spending power of the dollar.

${ }^{5}$ Calculation of percent changes in this report do not account for rounding of numbers in text.
} 
constant 1998 dollars, this equates to a decrease of 43.4 percent from $\$ 15.0$ billion in FY 1985 to $\$ 8.5$ billion in FY 1998, which reflects the reduced energy use and a 21.6 percent reduction in the inflation-adjusted cost of energy per quad. The Federal energy bill for FY 1998 increased 1.9 percent from the previous year.

Federal agencies report energy consumption under three categories: buildings and facilities, energy intensive operations, and vehicles and equipment.

\section{Buildings and Facilities}

In FY 1998, the Federal Government used 349.4 trillion British Thermal Units (Btu) to provide energy to approximately 500,000 buildings and facilities. This consumption represents a 25.8 percent decrease compared to FY 1985 and a 0.1 percent decrease relative to FY 1997. The cost of energy for buildings and facilities in FY 1998 was $\$ 3.5$ billion, a decrease of approximately $\$ 61.8$ million from FY 1997 expenditures, and a decrease of 38.4 percent from the FY 1985 expenditure of $\$ 5.7$ billion. ${ }^{6}$

During FY 1998, Federal agencies had three primary options for financing energy efficiency, water conservation, and renewable energy projects in buildings and facilities: direct appropriated funding, energy savings performance contracts (ESPCs), and utility-sponsored demand side management (DSM) incentives. Known funding from the three sources totaled approximately $\$ 377.2$ million in FY 1998. Direct appropriations accounted for approximately \$261.3 million. ESPC contracts awarded in FY 1998 resulted in \$114.4 million in estimated contractor investment, and agencies reported more than $\$ 1.5$ million in utility incentives received.

In FY 1998, direct appropriated funding identified by agencies for energy conservation retrofits and capital equipment increased 29.6 percent to $\$ 261.3$ million from $\$ 202.5$ million dollars in FY 1997. However, this is still 13.6 percent less than the FY 1995 appropriations.

\section{Energy Intensive Operations}

The energy intensive operations category covers energy used in buildings excluded from the 10 and 20 percent reduction goals for buildings and facilities under section 543 of NECPA, 42 U.S.C. $\$ \S 8253(\mathrm{a})(2)$ and 8253 (c). This category includes the energy consumed in industrial operations, certain research and development activities, and electronics-intensive facilities.

In FY 1998, the Federal Government used 65.9 trillion Btu of energy in energy intensive operations, approximately 6.3 percent of the total 1.04 quads consumed. Total energy consumption in this category increased 66.6 percent relative to FY 1985 and increased 0.7 percent relative to FY 1997. These increases are the result of changes in reporting procedures by individual agencies as well as changes in agency missions.

\footnotetext{
${ }^{6}$ Cost and consumption figures for FY 1985 may be different from those published in last year's Annual Report since Federal agencies update their files and provide revisions to their data.
} 
The Federal Government spent $\$ 621.3$ million on energy intensive operations energy in FY 1998, $\$ 52.9$ million less than the FY 1997 expenditure of $\$ 674.3$ million constant dollars.

\section{Vehicles and Equipment}

The vehicles and equipment category includes aircraft and naval fuels, automotive gasoline, diesel fuel consumed by Federally-owned and leased vehicles and privately-owned vehicles used for official business, and the energy used in Federal construction.

In FY 1998, the Federal Government used approximately 627.7 trillion Btu of energy in vehicles and equipment, nearly 60.2 percent of the total 1.04 quads consumed. Total energy consumption in vehicles and equipment decreased 32.8 percent relative to FY 1985 and was 5.7 percent less than the FY 1997 consumption of 665.4 trillion Btu. The Department of Defense consumed 580.0 trillion Btu or 92.4 percent of all vehicles and equipment energy used by the Federal Government.

The Federal Government spent $\$ 4.3$ billion on vehicles and equipment energy in FY 1998, \$273.1 million more than the FY 1997 expenditure.

\section{Agency Progress in Meeting Energy Reduction Goals}

NECPA, as amended by EPACT, requires agencies to take the steps necessary to reduce energy consumption in Federal buildings by 10 percent by 1995 compared to 1985 consumption levels, based on Btu per gross square foot, and requires a 20 percent reduction by 2000 compared to 1985 consumption levels. The 10 percent goal was met by the Government in FY 1995 with a 13.7 percent reduction from FY 1985. Executive Order 12902 added an additional goal of reducing energy consumption by 30 percent by the year 2005 relative to 1985 consumption levels. During FY 1998 agencies provided data to DOE that indicated a decrease in energy consumption per gross square foot by 18.7 percent relative to FY 1985. The Government's performance for each year since FY 1985 is illustrated in Figure ES-1. This reduction was the result of significant decreases in the consumption of fuel oil, natural gas, and coal. The use of non-electric fuels in Federal buildings has declined approximately 39.0 percent since 1985, while the consumption of electricity has increased by only 4.0 percent. The installation and increased use of electricity-driven electronic equipment contributed to increases in electricity, which peaked in FY 1990 at 11.7 percent above FY 1985. Since FY 1990, electricity consumption has declined 6.9 percent. Electricity now represents about 72.6 percent of the total energy costs of Federal buildings and accounts for 42.9 percent of total net energy consumption in buildings. This is compared to 30.6 percent of the total net energy consumption in buildings in FY 1985. Agency efforts undertaken in FY 1998 to increase energy efficiency in buildings included:

- improvement of operations and maintenance procedures;

- implementation of no-cost, low-cost efficiency measures;

- energy-efficient building retrofits and capital improvements;

- energy awareness activities and employee training programs; and

- procurement of energy-efficient goods and products. 
FIGURE ES-1

Decrease in Btu per Gross Square Foot

in Federal Buildings and Facilities from FY 1985

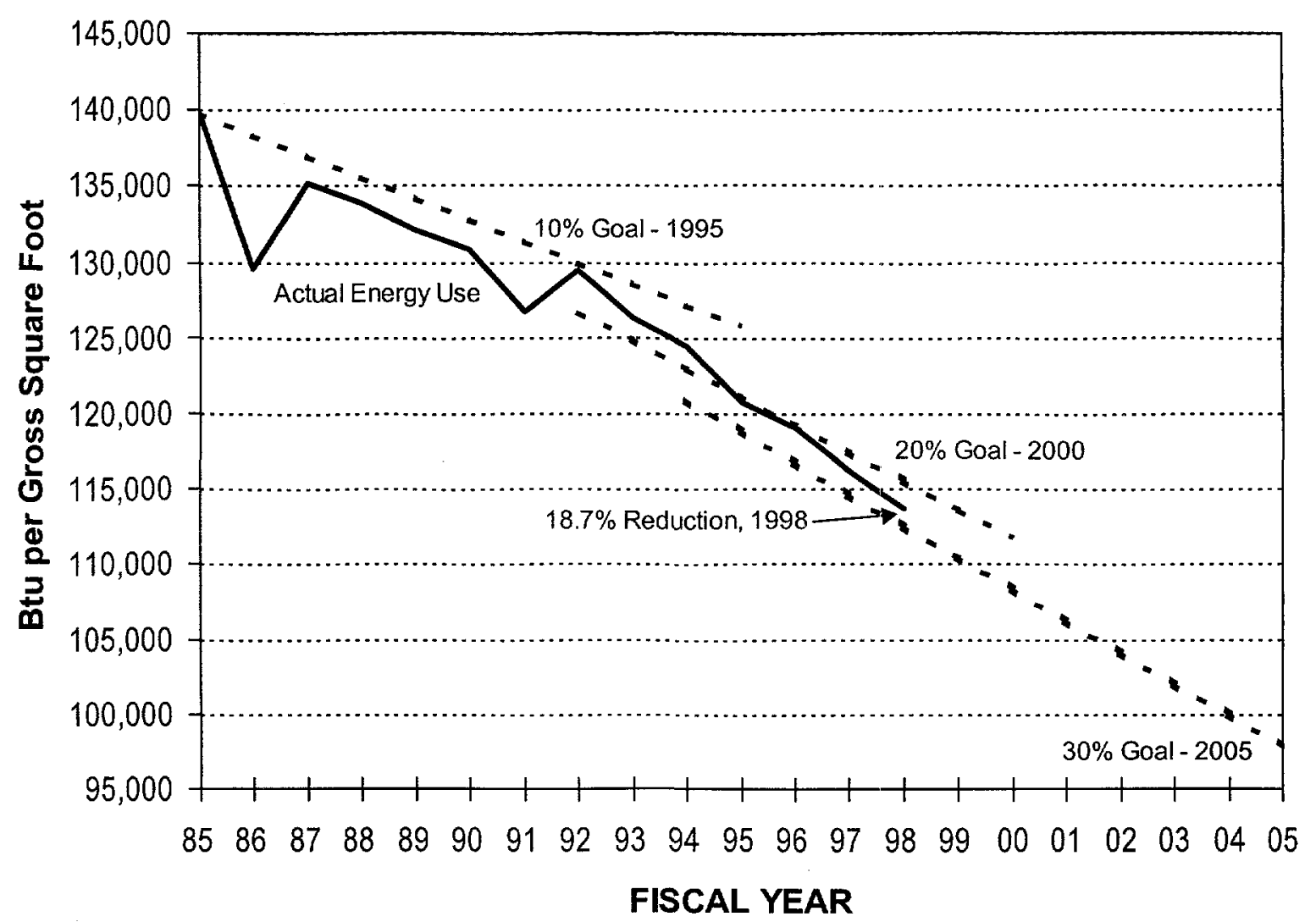

Executive Order 12902 expands the scope of Federal energy management activities beyond the NECPA mandates by establishing goals for industrial facilities. Section 301(b) of Executive Order 12902 requires agencies to implement programs in industrial facilities to increase energy efficiency by at least 20 percent in FY 2005 in comparison to FY 1990 consumption levels to the extent that measures undertaken to achieve the goal are cost-effective.

\section{Procurement of Energy-Efficient Products}

Section 507 of Executive Order 12902 requires all Federal agencies to buy "best practice" products when practicable, when they meet the agency's specific performance requirements, and are cost-effective. Best practice products are those which are in the upper 25 percent of energy efficiency for all similar products, or products that are at least 10 percent more efficient than the minimum level that meets Federal standards. During FY 1998, DOE continued its program to assist agencies in implementing the EPACT and Executive Order requirements for energy efficient procurement. In 1998, DOE's Federal Energy Management Program (FEMP) produced and distributed seven additional product energy efficiency recommendations to be added to the one-stop shopping guide, Buying Energy Efficient Products, to help Federal purchasers identify 
products which meet the energy efficiency requirements of Executive Order 12902. The guide now includes 29 product energy efficiency recommendations.

\section{Reducing Petroleum-Based Fuel Consumption}

Effective management of energy resources is of strategic importance to the Federal Government as well as the Nation. In FY 1998, petroleum-based fuels accounted for 0.67 quads of the total 1.04 quads consumed by the Federal Government, with 0.62 quads used by the Department of Defense, primarily for jet fuel and distillate/diesel for vehicles and equipment. The Federal Government consumed 35.9 percent less petroleum-based fuel in FY 1998 than in FY 1985. Figure ES-2 illustrates the trend in the Federal Government's use of petroleum fuels.

Due to the strategic nature of petroleum-based fuels, section 305 of Executive Order 12902 directs agencies to minimize the use of petroleum-based fuels in buildings and facilities. Federal agencies have made significant progress in reducing their dependence on petroleum-based fuels in their buildings and facilities. For example, Federal agencies report that in FY 1998, 40.3 trillion Btu of petroleum-based fuels were used for buildings and facilities energy, a 63.7 percent decrease from FY 1985 and a 4.0 percent decrease from FY 1997. This represents 11.5 percent of total buildings and facilities energy consumption.

FIGURE ES-2

\section{Federal Consumption of Petroleum-Based Fuels \\ FY 1985 through FY 1998}

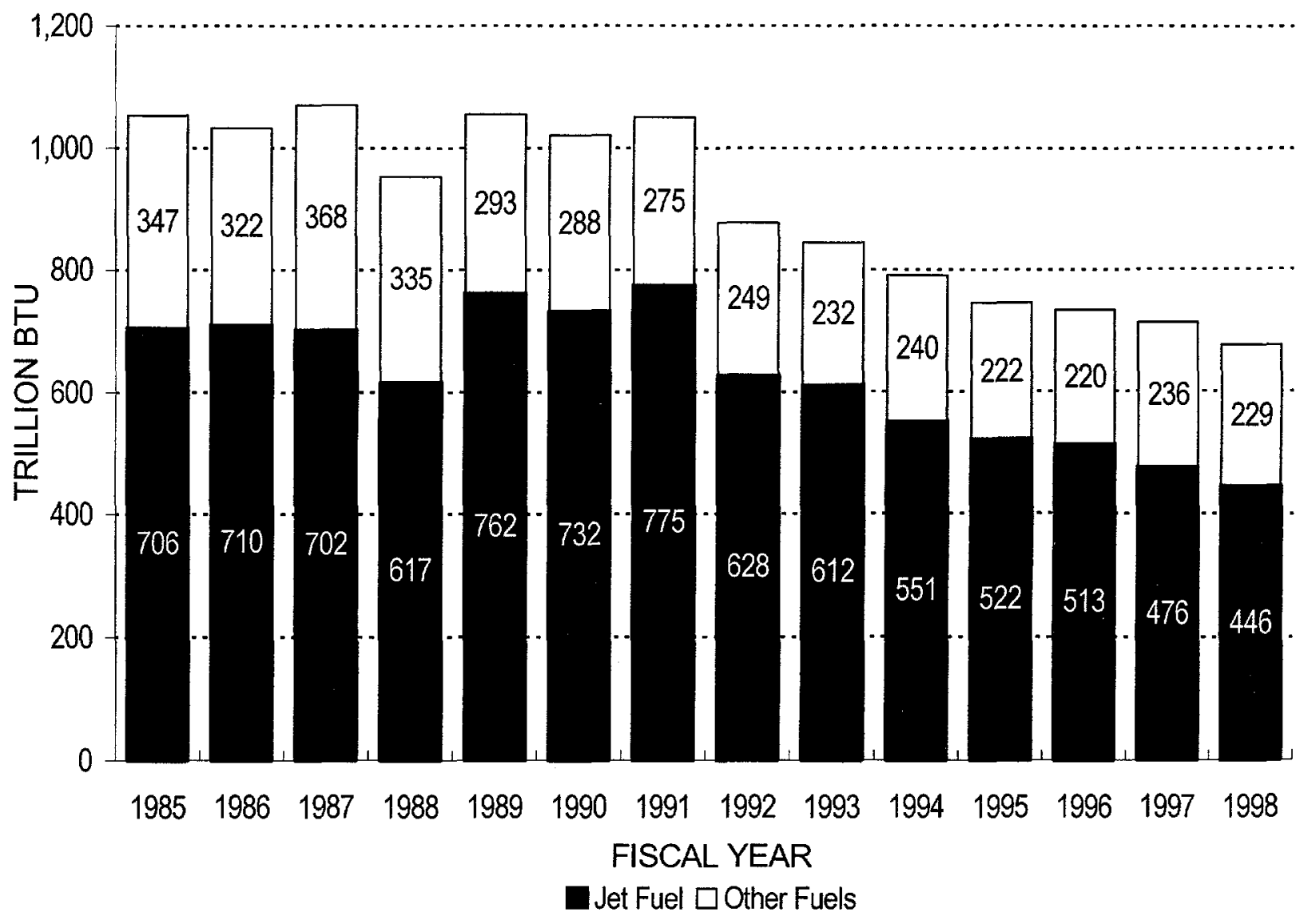




\section{Federal Energy Management Highlights}

Progress is being made in increasing Federal energy efficiency, although there remain opportunities for greater efficiency and cost reduction. Several of the most important findings of this report are listed below:

- The overall real cost of energy consumption in the Federal Government has fallen from $\$ 15.0$ billion in FY 1985 to $\$ 8.5$ billion in FY 1998.

- Total net energy consumption in FY 1998 decreased 27.8 percent from FY 1985.

- Energy consumption in buildings in FY 1998 decreased 25.8 percent from FY 1985.

- On a Btu-per-gross-square-foot basis, the 18.7 percent reduction in buildings energy puts the Federal Government well on track to meet the 20 percent reduction goal for 2000 .

- Five agencies, the Departments of Commerce, Energy, Justice, Transportation, and the National Aeronautics and Space Administration have surpassed a 20 percent reduction in buildings energy use per gross square foot from 1985 .

- Energy consumption in FY 1998 was used for the following purposes:

\section{End Use}

Buildings \& Facilities

Energy Intensive Operations

Vehicles \& Equipment
Percentage

33.5 percent

6.3 percent

60.2 percent

\section{Cost}

$\$ 3.5$ billion

$\$ 0.6$ billion

$\$ 4.4$ billion 


\section{OVERVIEW OF FEDERAL ENERGY MANAGEMENT ACTIVITIES}

\section{A. Overview of Federal Energy Management Policy and Legislative Mandates}

This report on Federal Energy Management for Fiscal Year (FY) 1998 provides information on energy consumption in Federal buildings and operations and documents activities conducted by Federal agencies to meet the statutory requirements of Title V, Part 3, of the National Energy Conservation Policy Act (NECPA), as amended, 42 U.S.C. $\S \S 8251-8259,8262,8262 \mathrm{~b}-\mathrm{k}$ and Title VIII of NECPA, 42 U.S.C. $\S 8287-8287$ c. Implementation activities undertaken during FY 1998 by the Federal agencies under the Energy Policy Act of 1992 (EPACT), Executive Order 12759 on Federal Energy Management, and Executive Order 12902, Energy Efficiency and Water Conservation at Federal Facilities, are also described in this report. In compliance with section 381(c) of the Energy Policy and Conservation Act (EPCA), as amended, 42 U.S.C. $\S$ $6361 \mathrm{c}$, this report also describes the energy conservation and management activities of the Federal Government under the authorization of section 381 of EPCA, 42 U.S.C. $\S 6361$.

\section{Requirements of National Energy Conservation Policy Act (NECPA) and Energy Policy Act of 1992 (EPACT)}

NECPA provides major policy guidance to Federal agencies to improve energy management in their facilities and operations. Amendments to NECPA made by the Federal Energy Management Improvement Act of 1988, 42 U.S.C. $\$ 8253$ (a)(1), required each agency to achieve a 10 percent reduction in energy consumption in its Federal buildings by FY 1995, when measured against a FY 1985 baseline on a Btu-per-gross-square-foot basis. It also directed DOE to establish life-cycle costing methods and coordinate Federal conservation activities through the Interagency Energy Management Task Force. Section 152 of Subtitle F of EPACT, Federal Agency Energy Management, further amends NECPA and contains provisions regarding energy management requirements, life-cycle cost methods and procedures, budget treatment for energy conservation measures, incentives for Federal facility energy managers, reporting requirements, new technology demonstrations, and agency surveys of energy-saving potential.

\section{Requirements of Executive Orders 12759 and 12902}

During FY 1998, two Executive Orders pertaining to energy management were in effect for Federal agencies. Executive Order 12759 on Federal Energy Management, signed by President Bush in April 1991, expanded the scope of Federal energy management activities beyond the NECPA requirements to include industrial facilities and Federal vehicles. Executive Order 12902, Energy Efficiency and Water Conservation at Federal Facilities, signed by President Clinton on March 8, 1994, supersedes Executive Order 12759 but leaves in effect sections 3, 9, and 10 of that Order.

The key requirements of the legislation and Executive Order authorities are outlined in the exhibit below along with current findings. 


\section{KEY REQUIREMENTS OF LEGISLATIVE AND EXECUTIVE ORDER AUTHORITIES}

\begin{tabular}{|c|c|c|c|}
\hline Statute/Directive & Requirement & FY 1998 Findings & $\begin{array}{l}\text { Annual Report } \\
\text { Discussion }\end{array}$ \\
\hline $\begin{array}{l}\text { Section 543, NECPA, } \\
42 \text { U.S.C., } \$ 8253(\mathrm{a})(1) \\
\text { Executive Order } 12902\end{array}$ & $\begin{array}{l}20 \text { percent reduction (Btu/GSF) } \\
\text { by } 2000 \text { from } 1985 \text {. } \\
30 \text { percent reduction (Btu/GSF) } \\
\text { in Federal buildings by } 2005 \\
\text { from } 1985 \text {. }\end{array}$ & $\begin{array}{l}\text { Federal agencies reported a } \\
18.7 \text { percent decrease in } \\
\text { energy consumption in } \\
\text { buildings in FY } 1998 \text {, } \\
\text { compared to FY } 1985 .\end{array}$ & $\begin{array}{l}\text { Section II }(B) \text {, } \\
\text { page } 54\end{array}$ \\
\hline $\begin{array}{l}\text { Section } 545 \text {, NECPA, } \\
42 \text { U.S.C., } \$ 8254\end{array}$ & $\begin{array}{l}\text { DOE to establish life-cycle cost } \\
\text { methods to determine cost- } \\
\text { effectiveness of proposed energy } \\
\text { efficiency projects. }\end{array}$ & $\begin{array}{l}\text { The } 1998 \text { edition of the } \\
\text { energy price indices and } \\
\text { discount factors for life- } \\
\text { cycle cost analysis was } \\
\text { published and distributed to } \\
\text { Federal energy managers. }\end{array}$ & $\begin{array}{l}\text { Section I }(F), \\
\text { page } 38\end{array}$ \\
\hline $\begin{array}{l}\text { Section } 545, \text { NECPA, } \\
42 \text { U.S.C., } § 8255\end{array}$ & $\begin{array}{l}\text { Transmit to Congress the amount } \\
\text { of appropriations requested in } \\
\text { each agency budget for electric } \\
\text { and energy costs incurred in } \\
\text { operating and maintaining } \\
\text { facilities and for compliance with } \\
\text { applicable statutes and directives. }\end{array}$ & $\begin{array}{l}\text { Approximately } \$ 261.3 \\
\text { million was appropriated } \\
\text { and spent on energy } \\
\text { efficiency projects in } \\
\text { Federal facilities. }\end{array}$ & $\begin{array}{l}\text { Section I }(E), \\
\text { page } 27\end{array}$ \\
\hline $\begin{array}{l}\text { Section 546, NECPA, } \\
42 \text { U.S.C., § 8256(a) }\end{array}$ & $\begin{array}{l}\text { Establishment of a program of } \\
\text { incentives within Federal } \\
\text { agencies to expedite Energy } \\
\text { Savings Performance Contracts. }\end{array}$ & $\begin{array}{l}\text { In FY } 1998,35 \text { convention- } \\
\text { al ESPC contracts were } \\
\text { awarded by agencies and } 9 \\
\text { delivery orders were issued } \\
\text { under DOE and DOD Super } \\
\text { ESPCs. }\end{array}$ & $\begin{array}{l}\text { Section } I(E) \text {, } \\
\text { page } 33\end{array}$ \\
\hline $\begin{array}{l}\text { Section 546, NECPA, } \\
42 \text { U.S.C., } \S 8256(\text { b) }\end{array}$ & $\begin{array}{l}\text { DOE to establish a Federal } \\
\text { Energy Efficiency Fund to } \\
\text { provide grants to agencies. }\end{array}$ & $\begin{array}{l}\text { There were no appropri- } \\
\text { ations for the Fund in FY } \\
1998 ; \text { FY } 1995 \text { funds were } \\
\text { allocated and progress of } \\
\text { the few remaining projects } \\
\text { is being monitored. }\end{array}$ & $\begin{array}{l}\text { Section } I(E), \\
\text { page } 31\end{array}$ \\
\hline $\begin{array}{l}\text { Section 157, EPACT, } \\
42 \text { U.S.C., } \S 8262 \text { (c) }\end{array}$ & $\begin{array}{l}\text { Federal agencies to establish and } \\
\text { maintain programs to train energy } \\
\text { managers and to increase the } \\
\text { number of trained energy } \\
\text { managers within each agency. }\end{array}$ & $\begin{array}{l}\text { DOE's FEMP conducted } 49 \\
\text { training workshops and } \\
\text { symposia for more than } \\
5,100 \text { attendees in the } \\
\text { efficient use and } \\
\text { conservation of energy, } \\
\text { water, and renewable } \\
\text { energy in Federal facilities. }\end{array}$ & $\begin{array}{l}\text { Section I }(D), \\
\text { page } 20 ; \\
\text { Section V, Agency } \\
\text { Reports, page } 77\end{array}$ \\
\hline Executive Order 12902 & $\begin{array}{l}20 \text { percent reduction (Btu/GSF) } \\
\text { for Federal industrial facilities by } \\
2005 \text { from } 1990 \text {. }\end{array}$ & $\begin{array}{l}\text { Findings are specific to } \\
\text { individual agencies. }\end{array}$ & $\begin{array}{l}\text { Section III (A), } \\
\text { page } 63\end{array}$ \\
\hline
\end{tabular}




\begin{tabular}{|c|c|c|c|}
\hline Statute/Directive & Requirement & FY 1998 Findings & $\begin{array}{l}\text { Annual Report } \\
\text { Discussion }\end{array}$ \\
\hline Executive Order 12902 & $\begin{array}{l}\text { Conduct prioritization surveys to } \\
\text { establish facility audit priorities. } \\
\text { Implement } 10 \text {-year plan to } \\
\text { conduct comprehensive audits. }\end{array}$ & $\begin{array}{l}\text { Findings are specific to } \\
\text { individual agencies. }\end{array}$ & $\begin{array}{l}\text { Section V, Agency } \\
\text { Reports, page } 77\end{array}$ \\
\hline $\begin{array}{l}\text { Executive Order } 12759 \\
\text { Executive Order } 12902\end{array}$ & $\begin{array}{l}\text { Minimize the use of petroleum } \\
\text { products for facilities operations } \\
\text { or building purposes through } \\
\text { switching to an alternative energy } \\
\text { source if it is estimated to } \\
\text { minimize life-cycle costs; } \\
\text { improve the efficiency with } \\
\text { which petroleum is used in } \\
\text { facilities where alternative fuels } \\
\text { are not practical or cost-effective. }\end{array}$ & $\begin{array}{l}\text { The consumption of } \\
\text { petroleum-based fuels in } \\
\text { buildings during FY } 1998 \\
\text { decreased } 63.7 \text { percent } \\
\text { compared to FY } 1985 \text { and } \\
4.0 \text { percent from FY } 1997 .\end{array}$ & $\begin{array}{l}\text { Section II (A), } \\
\text { page } 46\end{array}$ \\
\hline Executive Order 12902 & $\begin{array}{l}\text { Agencies should strive to } \\
\text { purchase products in the top } 25 \\
\text { percent of their class for energy } \\
\text { efficiency. }\end{array}$ & $\begin{array}{l}\text { Seven new product energy } \\
\text { efficiency recommendations } \\
\text { were issued by DOE, } \\
\text { bringing the total to } 29 \text {. }\end{array}$ & $\begin{array}{l}\text { Section } I(G), \\
\text { page } 38\end{array}$ \\
\hline Executive Order 12902 & $\begin{array}{l}\text { Agencies to ensure design and } \\
\text { construction of new buildings } \\
\text { meet or exceed whichever energy } \\
\text { performance standards will result } \\
\text { in a lower life-cycle cost over the } \\
\text { life of the building. Also } \\
\text { contains provisions for agencies } \\
\text { to showcase their best efficiency } \\
\text { and renewable energy projects. }\end{array}$ & $\begin{array}{l}\text { The proposed rule, Energy } \\
\text { Code for New Federal } \\
\text { Commercial and Multi- } \\
\text { Family High Rise } \\
\text { Residential Buildings } \\
\text { revises the interim Federal } \\
\text { standards to conform } \\
\text { generally with the codified } \\
\text { version of ASHRAE } \\
\text { Standard 90.1-1989. }\end{array}$ & $\begin{array}{l}\text { Section II (D), } \\
\text { page } 61 ; \\
\text { Section I (D), } \\
\text { page } 26\end{array}$ \\
\hline
\end{tabular}




\section{B. Overall Federal Energy Consumption, Costs, and Carbon Emissions}

As shown in Table 1-A, the total primary energy consumption of the Government of the United States, including energy consumed to produce, process, and transport energy, was 1.49 quadrillion British Thermal Units (quads) or 1,493,699.4 billion Btu during FY 1998. Primary energy consumption considers all resources used to generate and transport electricity and steam. (The source conversion factors of 11,600 Btu per kilowatt hour for electricity and 1,390 Btu per pound of steam are used to calculate primary energy consumption. See Appendix B for conversion factors used to calculate net energy consumption.) These 1.49 quads represent approximately 1.6 percent of the total 94.23 quads $^{7}$ used in the United States, and reflect Government energy consumption in buildings and operations to provide essential services to its citizens, including the defense of the Nation. In total, the Federal Government is the single largest energy consumer in the Nation, although its pattern of consumption is widely dispersed.

Based on reports submitted to DOE by 29 Federal agencies, the Government consumed 1.04 quads during FY 1998 when measured in terms of energy actually delivered to the point of use (net consumption). As shown in Table 1-B, Federal agencies reported a 27.8 percent decrease in total net energy consumption compared to FY 1985, and a 3.5 percent decrease from FY 1997. The cost of this energy was $\$ 8.5$ billion and represented approximately 0.5 percent of the total Federal expenditures of $\$ 1.652$ trillion $^{8}$ for all purposes in FY 1998. The Federal energy bill for FY 1998 rose 1.9 percent from the previous year, increasing $\$ 158.3$ million in constant dollars compared to FY 1997.9

In FY 1998, the Department of Defense spent $\$ 6.3$ billion for energy of the total Federal energy expenditure of $\$ 8.5$ billion. Overall, the Department of Defense used 33.1 percent less net energy in FY 1998 than in FY 1985.

Figures 1 and 2 depict the percentage of total energy used by the Federal Government in FY 1998 and its cost. As illustrated, jet fuel and electricity account for approximately 60.4 percent of the total energy consumption represented in Figure 1 and approximately 72.8 percent of the total energy costs in Figure 2.

Petroleum-based fuels used by the Federal Government are shown in Table 2. In FY 1998, petroleum-based fuels accounted for 0.67 quads $(674,413.7$ billion Btu) of the total 1.04 quads consumed by the Federal Government. Of that, approximately 0.62 quads $(616,900.2$ billion Btu) were used by the Department of Defense primarily for jet fuel and distillate/diesel for vehicles and equipment energy. Only 0.04 quads (40,335.3 billion Btu) of petroleum-based fuels were used for Federal buildings and facilities energy.

\footnotetext{
${ }^{7}$ DOE/EIA-0384(98), Annual Energy Review 1998, July 1999.

${ }^{8}$ Analytical Perspectives, Budget of the United States Government, Fiscal Year 1998.

${ }^{9}$ Appendix $\mathrm{C}$ indicates the annual cost of energy used in Federal buildings and facilities, vehicles and equipment, and energy intensive operations for FY 1985 through FY 1998. The combined cost per Btu for energy in each fiscal year is also shown in the table.
} 
TABLE 1-A

TOTAL PRIMARY ENERGY CONSUMPTION BY FEDERAL AGENCIES

(In Billions of Btu, with Conversions to Millions of Barrels of Oil Equivalent [MBOE], and Petajoules [Joule x $10^{15}$ )

\begin{tabular}{|c|c|c|c|c|c|c|c|c|c|c|c|c|}
\hline $\begin{array}{l}\text { CIVILIAN } \\
\text { AGENCY }\end{array}$ & $\begin{array}{c}F Y \\
1985\end{array}$ & $\begin{array}{l}\text { FY } \\
1990\end{array}$ & $\begin{array}{l}\text { FY } \\
1991\end{array}$ & $\begin{array}{c}\text { FY } \\
1992\end{array}$ & $\begin{array}{c}F Y \\
1993\end{array}$ & $\begin{array}{c}F Y \\
1994\end{array}$ & $\begin{array}{c}\text { FY } \\
1995\end{array}$ & $\begin{array}{c}F Y \\
1996\end{array}$ & $\begin{array}{c}\text { FY } \\
1997\end{array}$ & $\begin{array}{c}F Y \\
1998\end{array}$ & $\begin{array}{c}\% \text { CHANGE } \\
85-98\end{array}$ & $\begin{array}{c}\% \text { CHANGE } \\
97-98\end{array}$ \\
\hline USPS & $50,965.1$ & $59,097.8$ & $60,543.2$ & $62,372.2$ & $66,638.9$ & $68,794.2$ & $71,122.5$ & $72,974.3$ & $77,219.9$ & $78,105.4$ & 53.3 & 1.1 \\
\hline DOE & $97,530.8$ & $89,471.1$ & $86,100.8$ & $89,434.3$ & $86,005.9$ & $85,216.0$ & $87,272.7$ & $87,241.0$ & $76,266.5$ & $69,891.0$ & -28.3 & -8.4 \\
\hline VA & $42,926.5$ & $44,337.2$ & $45,271.6$ & $45,394.6$ & $46,284.4$ & $46,639.8$ & $47,176.6$ & $48,722.9$ & $49,618.4$ & $50,279.6$ & 17.1 & 1.3 \\
\hline GSA & $42,963.0$ & $36,590,2$ & $36,880.8$ & $36,282.5$ & $37,008,9$ & $36,468.2$ & $35,962,8$ & $36,827.8$ & $37,006.6$ & $36,763.3$ & -14.4 & -0.7 \\
\hline$S T^{1}$ & 704.0 & 852.2 & 845.4 & 829.4 & $1,177.8$ & $1,263.2$ & $1,316.1$ & $1,867.7$ & $2,021.4$ & $19,882.4$ & $2,724.2$ & 883.6 \\
\hline DOJ & $11,026.6$ & $11,474,0$ & $14,162.8$ & $12,961,0$ & $14,835.4$ & $16,632.6$ & $16,988.4$ & $20,590.3$ & $20,066.7$ & $24,693.2$ & 123.9 & 23.1 \\
\hline HHS & $10,831.3$ & $16,191.3$ & $14,353.7$ & $15,857,0$ & $16,264.1$ & $16,497.0$ & $12,010.3$ & $12,642.0$ & $14,755.3$ & $14,414.6$ & 33.1 & -2.3 \\
\hline NASA & $23,365.1$ & $28,192.7$ & $29,141.7$ & $29,443.6$ & $29,269.1$ & $29,875.9$ & $28,939.4$ & $26,787.6$ & $28,311.7$ & $27,454.2$ & 17.5 & -3.0 \\
\hline DOT & $28,447.5$ & $28,379.3$ & $29,029.7$ & $30,713.0$ & $33,831.2$ & $29,865,5$ & $28,329.5$ & $31,426.4$ & $30,542.2$ & $31,950.0$ & 12.3 & 4.6 \\
\hline DOI & $11,486.5$ & $10,864.3$ & $10,955.6$ & $10,643.5$ & $11,828.6$ & $12,156.2$ & $10,428.9$ & $7,525.1$ & $10,147.6$ & $10,102.0$ & -12.1 & -0.4 \\
\hline USDA & $12,152.0$ & $14,397.6$ & $14,590.7$ & $14,039.6$ & $14,426.5$ & $14,494,1$ & $14,851.9$ & $14,099.9$ & $12,272.1$ & $12,972.8$ & 6.8 & 5.7 \\
\hline TRSY & $3,606.0$ & $6,477,3$ & $7,960.4$ & $8,699.7$ & $8,561.0$ & $8,419.7$ & $7,677.7$ & $7,139.0$ & $9,033.4$ & $8,831.4$ & 144.9 & -2.2 \\
\hline $\mathrm{DOL}$ & $3,920.0$ & $4,103.2$ & $4,186.7$ & $4,209.9$ & $4,324.2$ & $4,403.2$ & $4,279.0$ & $4,381.1$ & $4,415.2$ & $4,459.7$ & 13.8 & 1.0 \\
\hline$T_{V A}{ }^{2}$ & $1,899.5$ & $1,887.1$ & $1,958.1$ & $1,830.8$ & $1,917.5$ & $7,436.2$ & $7,484.9$ & $7,172.5$ & $6,985.7$ & $6,757.7$ & 255.8 & -3.3 \\
\hline EPA & $1,750.5$ & $1,616.4$ & $1,782.6$ & $1,811.6$ & $1,998.8$ & $2,082.1$ & $2,231.2$ & $2,172.7$ & $2,211.8$ & $2,181.1$ & 24.6 & -1.4 \\
\hline DOC & $4,038.8$ & $6,327.7$ & $4,536.0$ & $4,372.8$ & $4,636.9$ & $5,392.2$ & $5,585.1$ & $5,297.0$ & $5,251.9$ & $4,933.8$ & 22.2 & -6.1 \\
\hline HUD & 349.3 & 426.5 & 449.7 & 417.7 & 380.2 & 354.4 & 341.5 & 358.4 & 348.8 & 333.8 & -4.5 & -4.3 \\
\hline FCC & 42.0 & 50.1 & 50.9 & 41.3 & 42.3 & 46.0 & 46.0 & 36.4 & 38.8 & 38.3 & -8.8 & -1.3 \\
\hline PCC & $1,189,4$ & $1,399.5$ & $1,358.9$ & $1,461.0$ & $1,467.0$ & $1,479.4$ & $1,687.2$ & $1,683.2$ & $1,634.2$ & 0.0 & -100.0 & -100.0 \\
\hline OTHER* & 986.7 & $4,068.2$ & $3,079,3$ & $3,136,0$ & $3,489.2$ & $4,418.4$ & $6,782.8$ & $9,345.5$ & $10,165.5$ & $9,703.9$ & 883.4 & -4.5 \\
\hline \multicolumn{13}{|c|}{ CIVILIAN AGENCIES } \\
\hline TOTAL & $350,180.6$ & $366,203.6$ & $367,238.4$ & $373,951.5$ & $384,387.9$ & $391,934.3$ & $390,514,8$ & $398,290.8$ & $398,313.8$ & $413,748.0$ & 18.2 & 3.9 \\
\hline DOD & $1,494,704.2$ & $1,536,176.1$ & $1,554,075.0$ & $1,388,726.4$ & $1,330,916.1$ & $1,253,516.9$ & $1,189,980.4$ & $1,158,615.9$ & $1,127,262.1$ & $1,079,951.4$ & -27.7 & -4.2 \\
\hline \multicolumn{13}{|c|}{ ALLAGENCIES } \\
\hline TOTAL & $1,844,884.8$ & $1,902,379.7$ & $1,921,313.4$ & $1,762,677.8$ & $1,715,304.1$ & $1,645,451.2$ & $1,580,495.1$ & $1,556,906.7$ & $1,525,575.9$ & $1,493,699.4$ & -19.0 & -2.1 \\
\hline MBOE & 316.7 & 326,6 & 329.8 & 302.6 & 294.5 & 282.5 & 271.3 & 267.3 & 261.9 & 256.4 & & \\
\hline Petajoules & $1,946.3$ & $2,006,9$ & $2,026.9$ & $1,859.6$ & $1,809.6$ & $1,735.9$ & $1,667.4$ & $1,642.5$ & $1,609.4$ & $1,575.8$ & & \\
\hline
\end{tabular}

*Other includes, for certain years, CFTC, CIA, EEOC, FEMA, FTC, NARA, NSF, NRC, OPM, RRB, SSA, USIA, and FERC.

DATA AS OF 01/10/00

' In 1998, the State Department developed a statistical method for estimating the energy consumption of its foreign buildings worldwide and included the estimate in their 1998 data. Foreign building consumption has not been reported in full in previous years.

${ }^{2}$ TVA's increase in energy consumption beginning in FY 1994 is the result of first-time reporting of energy consumed at generation sites.

Note: This table uses a conversion factor for electricity of 11,600 Btu per kilowatt hour and 1,390 Btu per pound of steam. Agencies are listed in descending order of consumption for the current year. Sum of components may not equal total due to independent rounding.

Source: Federal Agency Annual Energy Management Data Reports 
TABLE 1-B

TOTAL NET ENERGY CONSUMPTION BY FEDERAL AGENCIES

(In Billions of Btu, with Conversions to Millions of Barrels of Oil Equivalent [MBOE], and Petajoules [Joule x 10 ${ }^{15}$ )

\begin{tabular}{|c|c|c|c|c|c|c|c|c|c|c|c|c|}
\hline $\begin{array}{l}\text { CIVILIAN } \\
\text { AGENCY }\end{array}$ & $\begin{array}{c}\text { FY } \\
1985\end{array}$ & $\begin{array}{l}F Y \\
1990\end{array}$ & $\begin{array}{c}F Y \\
1991\end{array}$ & $\begin{array}{l}\text { FY } \\
1992\end{array}$ & $\begin{array}{c}\text { FY } \\
1993\end{array}$ & $\begin{array}{c}F Y \\
1994\end{array}$ & $\begin{array}{c}\text { FY } \\
1995\end{array}$ & $\begin{array}{c}\text { FY } \\
1996\end{array}$ & $\begin{array}{c}\text { FY } \\
1997\end{array}$ & $\begin{array}{c}\text { FY } \\
1998\end{array}$ & $\begin{array}{c}\% \text { CHANGE } \\
85-98\end{array}$ & $\begin{array}{c}\% \text { CHANGE } \\
97-98\end{array}$ \\
\hline USPS & $27,762.5$ & $30,616.2$ & $30,817.0$ & $31,674.2$ & $33,725.1$ & $34,950.8$ & $36,220.9$ & $36,427,1$ & $40,760.0$ & $39,876.9$ & 43.6 & -2.2 \\
\hline DOE & $52,271.5$ & $43,467.5$ & $42,178.6$ & $44,300.2$ & $43,688.5$ & $42,279.2$ & $47,089.7$ & $44,424.9$ & $33,926.3$ & $31,450.1$ & -39.8 & -7.3 \\
\hline VA & $25,144.7$ & $24,898,4$ & $25,050.4$ & $25,254.9$ & $25,741.2$ & $25,587.8$ & $25,428.9$ & $26,832.9$ & $27,261.1$ & $27,597.2$ & 9.8 & 1.2 \\
\hline DOT & $19,342.4$ & $18,965.2$ & $18,971.4$ & $17,027.3$ & $19,360.1$ & $19,772.6$ & $18,400.0$ & $19,353.2$ & $19,172.6$ & $18,612.2$ & -3.8 & -2.9 \\
\hline DOJ & $8,176.0$ & $6,961.6$ & $8,018.3$ & $7,544.3$ & $9,081.7$ & $10,263.6$ & $10,193.3$ & $12,127.7$ & $11,999.9$ & $15,805.1$ & 93.3 & 31.7 \\
\hline GSA & $17,330.7$ & $14,226.0$ & $13,985.0$ & $13,842.0$ & $14,149.4$ & $13,963.0$ & $13,671.8$ & $14,499.2$ & $14,364.3$ & $14,096.2$ & -18.7 & -1.9 \\
\hline NASA & $10,827.9$ & $12,321.8$ & $12,455.4$ & $12,538.8$ & $12,358.7$ & $12,588.3$ & $12,395.3$ & $11,480.6$ & $11,980.3$ & $11,717.1$ & 8.2 & -2.2 \\
\hline USDA & $8,358.7$ & $9,519.6$ & $9,599.6$ & $9,100.6$ & $9,332.9$ & $9,412.9$ & $9,728.8$ & $9,056.9$ & $7,370.7$ & $7,917.0$ & -5.3 & 7.4 \\
\hline$S T^{1}$ & 246.9 & 302.6 & 274.2 & 273.8 & 390.2 & 422.3 & 437.3 & 653.3 & 721.4 & $7,787.9$ & $3,054.3$ & 979.6 \\
\hline HHS & $6,210.5$ & $7,957.0$ & $7,107.1$ & $7,954.7$ & $8,146.3$ & $8,408.3$ & $6,129.7$ & $6,628.9$ & $7,852.8$ & $7,400.8$ & 19.2 & -5.8 \\
\hline DOI & $7,816.3$ & $7,391.9$ & $7,094.8$ & $6,992.4$ & $7,482.1$ & $7,892.2$ & $6,378.4$ & $4,326.6$ & $6,612.2$ & $6,427.3$ & -17.8 & -2.8 \\
\hline TRSY & $2,770.0$ & $3,391.6$ & $4,177.1$ & $4,628.4$ & $4,912.7$ & $4,558.2$ & $4,132.6$ & $3,764.1$ & $4,597.6$ & $4,816.3$ & 73.9 & 4.8 \\
\hline $\mathrm{DOL}$ & $2,385.2$ & $2,376.0$ & $2,446.0$ & $2,452.4$ & $2,514.9$ & $2,527.9$ & $2,385.7$ & $2,491.5$ & $2,490.2$ & $2,540.4$ & 6.5 & 2.0 \\
\hline $\mathrm{DOC}$ & $2,489.1$ & $4,476.3$ & $2,722.2$ & $2,460.1$ & $2,338.4$ & $2,858.3$ & $2,882.8$ & $2,883.1$ & $2,721.4$ & $2,470.3$ & -0.8 & -9.2 \\
\hline$T^{T} A^{2}$ & 980.9 & 904.5 & 961.3 & 834.4 & 892.1 & $2,534.9$ & $2,607.3$ & $2,547.8$ & $2,396.9$ & $2,295.9$ & 134.1 & -4.2 \\
\hline EPA & 904.5 & 747.0 & 822.4 & 839.7 & 994.8 & $1,041.2$ & $1,120.6$ & $1,099.7$ & $1,148.3$ & $1,120.6$ & 23.9 & -2.4 \\
\hline HUD & 116.9 & 140.3 & 164.9 & 156.7 & 147.8 & 144.2 & 131.3 & 140.8 & 137.6 & 126.4 & 8.1 & -8.1 \\
\hline FCC & 23.6 & 23.9 & 22.1 & 19.9 & 20.2 & 20.7 & 20.7 & 17.5 & 19.9 & 19.4 & -17.9 & -2.5 \\
\hline PCC & 724.2 & 873.1 & 808.1 & 923.5 & 914.9 & 921.0 & $1,108.0$ & $1,080.8$ & $1,021.9$ & 0.0 & -100.0 & -100.0 \\
\hline OTHER* & 408.2 & $2,175.0$ & $1,382.0$ & $1,460.4$ & $1,604.1$ & $1,981.0$ & $2,979.7$ & $3,716.2$ & $3,998.7$ & $3,870.0$ & 848.0 & -3.2 \\
\hline \multicolumn{13}{|c|}{ CIVILIAN AGENCIES } \\
\hline TOTAL & $194,290.9$ & $191,735.5$ & $189,057.7$ & $190,278.6$ & $197,796.1$ & $202,128.4$ & $203,442.9$ & $203,552.9$ & $200,554.0$ & $205,947.0$ & 6.0 & 2.7 \\
\hline DOD & $1,250,613.8$ & $1,241,655.8$ & $1,269,291.5$ & $1,103,990.1$ & $1,048,772.9$ & $977,040.4$ & $926,022.9$ & $904,150.2$ & $880,007.7$ & $837,115.8$ & -33.1 & -4.9 \\
\hline \multicolumn{13}{|c|}{ ALL AGENCIES } \\
\hline TOTAL & $1,444,904.7$ & $1,433,391.3$ & $1,458,349.2$ & $1,294,268.7$ & $1,246,569.0$ & $1,179,168.8$ & $1,129,465.7$ & $1,107,703.1$ & $1,080,561.7$ & $1,043,062.8$ & -27.8 & -3.5 \\
\hline MBOE & 248.1 & 246.1 & 250.4 & 222.2 & 214.0 & 202.4 & 193.9 & 190.2 & 185.5 & 179.1 & & \\
\hline Petajoules & $1,524.3$ & $1,512.2$ & $1,538.5$ & $1,365.4$ & $1,315.1$ & $1,244.0$ & $1,191.5$ & $1,168.6$ & $1,140.0$ & $1,100.4$ & & \\
\hline
\end{tabular}

*Other includes, for certain years, CFTC, CIA, EEOC, FEMA, FTC, NARA, NSF, NRC, OPM, RRB, SSA, USIA, and FERC.

1 'In 1998, the State Department developed a statistical method for estimating the energy consumption of its foreign buildings worldwide and included the estimate in their 1998 data. Foreign building consumption has not been reported in full in previous years.

'TVA's increase in energy consumption beginning in FY 1994 is the result of first-time reporting of energy consumed at generation sites.

Note: This table uses a conversion factor for electricity of 3,412 Btu per kilowatt hour and 1,000 Btu per pound of steam. Agencies are listed in descending order of consumption for the current year. Sum of components may not equal total due to independent rounding.

Source: Federal Agency Annual Energy Management Data Reports 


\section{Federal Energy Consumption, FY 1998}

Total by Energy Type: 1.04 quads

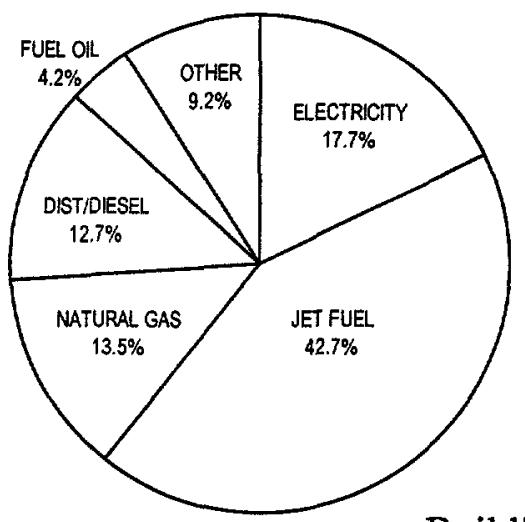

Total by Sector: 1.04 quads

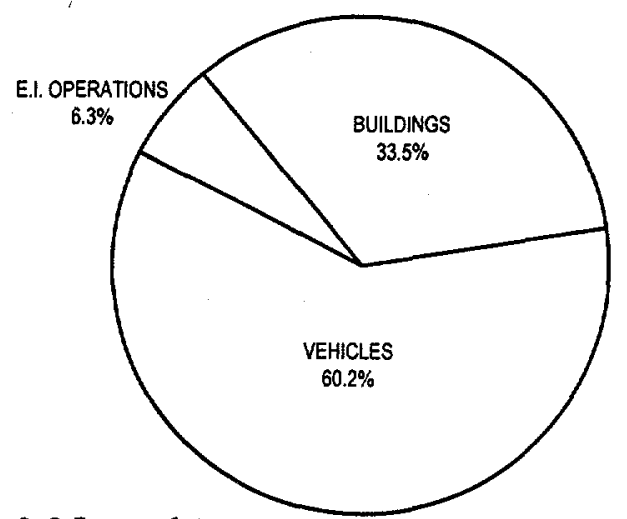

Buildings \& Facilities: 0.35 quads

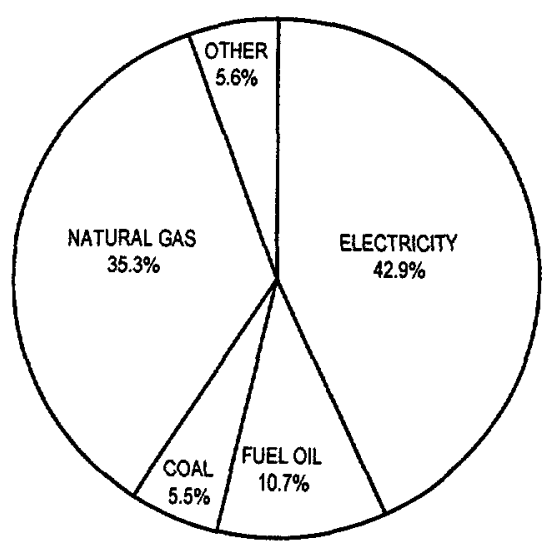

Energy Intensive Operations: 0.07 quads

Vehicles \& Equipment: 0.63 quads
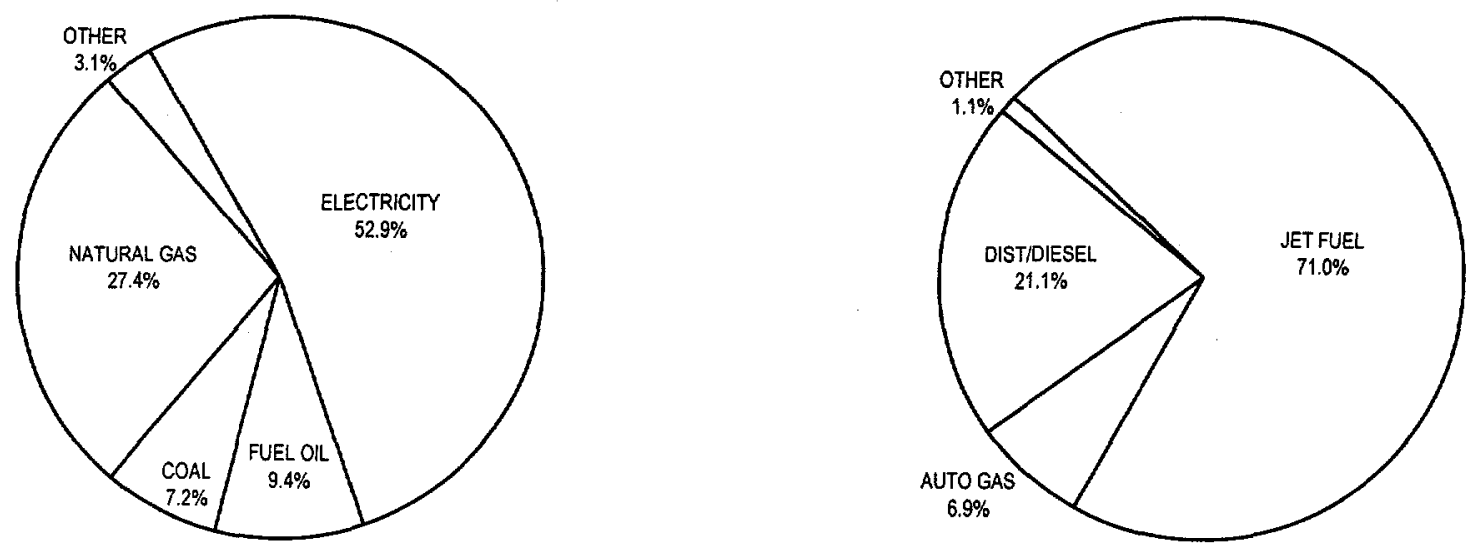

Data as of $01 / 10 / 00$

Source: Federal Agency Annual Energy Management Data Reports

Note: Sum of components may not equal 100-percent due to independent rounding. 
FIGURE 2

Federal Energy Costs, FY 1998

Total by Energy Type: $\$ 8.50$ Billion

Total by Sector: $\$ 8.50$ Billion
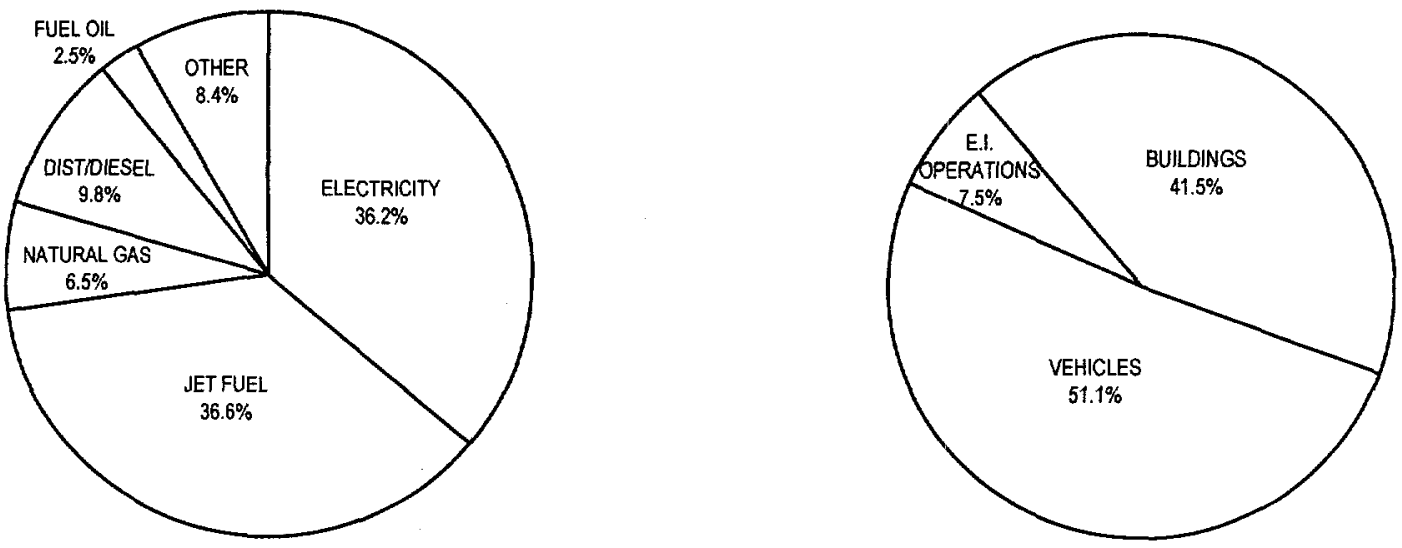

Buildings \& Facilities: $\$ 3.53$ Billion

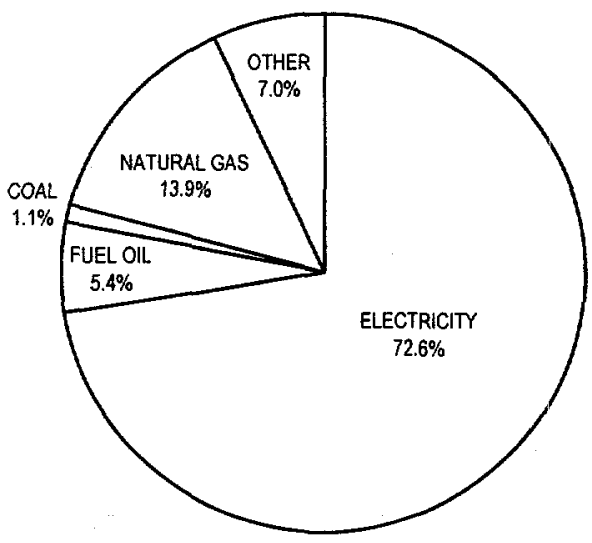

Energy Intensive Operations: $\$ 0.62$ Billion

Vehicles \& Equipment: $\$ 4.35$ Billion
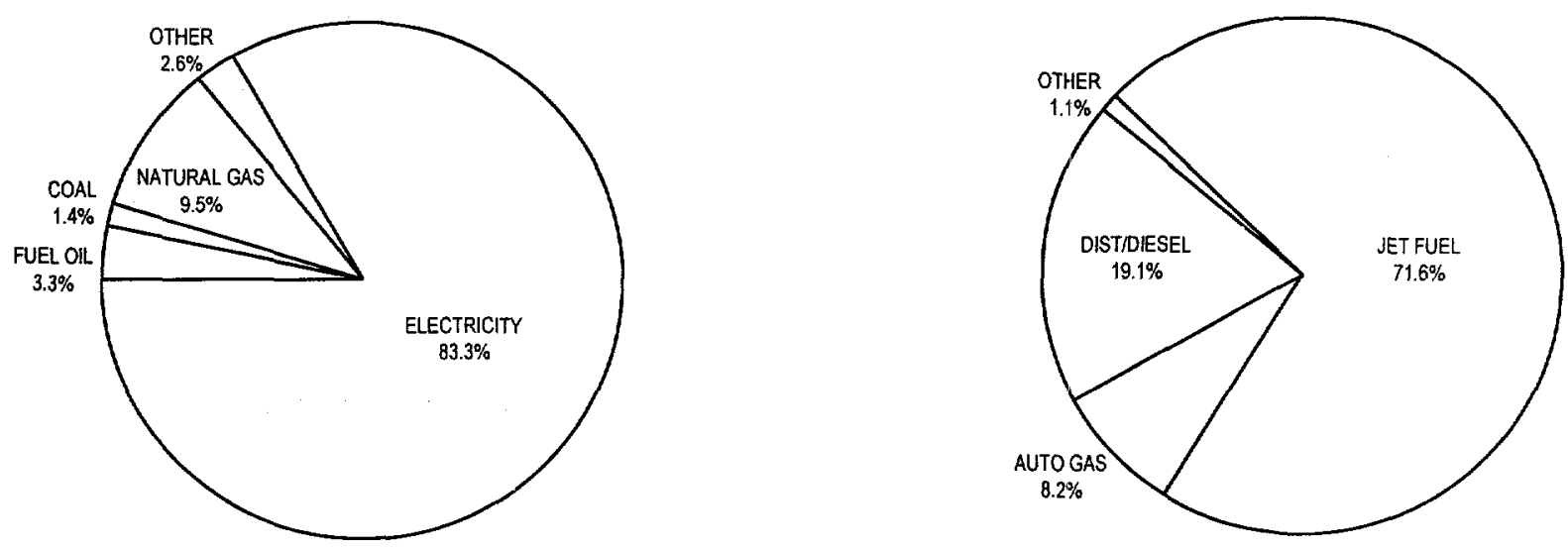

Data as of $01 / 10 / 00$

Source: Federal Agency Annual Energy Management Data Reports

Note: Sum of components may not equal 100 percent due to independent rounding. 
TABLE 2

FEDERAL PETROLEUM USAGE IN FY 1998

(in Thousands of Gallons, Billions of Btu, and Petajoules [Joule x $10^{15}$ ])

\section{Unit Total}

(KGal)

Buildings \& Facilities

$\vec{v}$

\section{Fuel Oil}

LPG/Propane

\section{Energy Intensive Operations}

Fuel Oil

LPG/Propane

\section{Vehicles \& Equipment}

\section{Motor Gas}

$269,175.7$

$31,419.9$

$44,758.0$

$1,472.4$

$344,403.8$
$953,952.9$
$1,679.5$
$3,427,079.5$
0.0
$4,115.3$
$6,242.9$

Total

BBTU* $^{*}$
DOD

$30,769.4$

$1,585.1$

$4,510.5$

75.5

$15,326.1$

$126,593.8$

0.4

$437,760.4$

0.0

74.0

205.1

$616,900.2$

\section{BBTU* \\ Civilian}

$6,565.2$

$1,415.5$

$1,697.5$

65.1

$27,724.3$

$5,719.5$

209.6

$7,760.0$

0.0

319.0

$6,037.8$

$57,513.5$

*Uses a conversion factor of:

95,500 Btu/gallon for LPG/propane

$138,700 \mathrm{Btu} / \mathrm{gallon}$ for fuel oil, distillate-diesel \& petroleum, and navy special

$125,000 \mathrm{Btu} / \mathrm{gallon}$ for motor gasoline and aviation gasoline

$130,000 \mathrm{Btu} /$ gallon for jet fuel

947.9 Billion Btu/Petajoule

Note: FY 1998 contains estimated data for the following agencies: FEMA, FTC, and OPM. Sum of components may not equal total due to independent rounding.

Source: Federal Agency Annual Energy Management Data Reports 
Carbon emissions from Federal Government energy consumption have decreased significantly since FY 1990, the base year for the Kyoto Protocol to the United Nations Framework on Climate Change. As shown in Figure 3, the Federal Government has reduced carbon emissions across the three end-use sectors by 23.7 percent from 33.2 million metric tons in FY 1990 to 25.3 million metric tons in FY $1998 .{ }^{10}$ The largest contribution to this reduction is from the vehicles and equipment sector, which has seen a decrease in carbon emissions of 32.2 percent. This is a result of a reduction of almost 5.5 million metric tons of carbon emissions from jet fuel, as well as smaller reductions from diesel, aviation gasoline, navy special, and LPG/propane.

Carbon emissions have decreased by 16.2 percent in the buildings and facilities sector since 1990. Contributing to this reduction was a 10.9 percent reduction in gross square footage since FY 1990 and a 5.8 percent decrease in primary energy intensity $(246,974$ Btu/GSF in FY 1990, 232,752 Btu/GSF in FY 1998). Carbon emissions from energy intensive activities in excluded buildings increased 1.8 percent $(47,344.4$ metric tons) since FY 1990.

FIGURE 3

\section{Carbon Emissions from Federal Energy Consumption, FY 1990 to FY 1998}

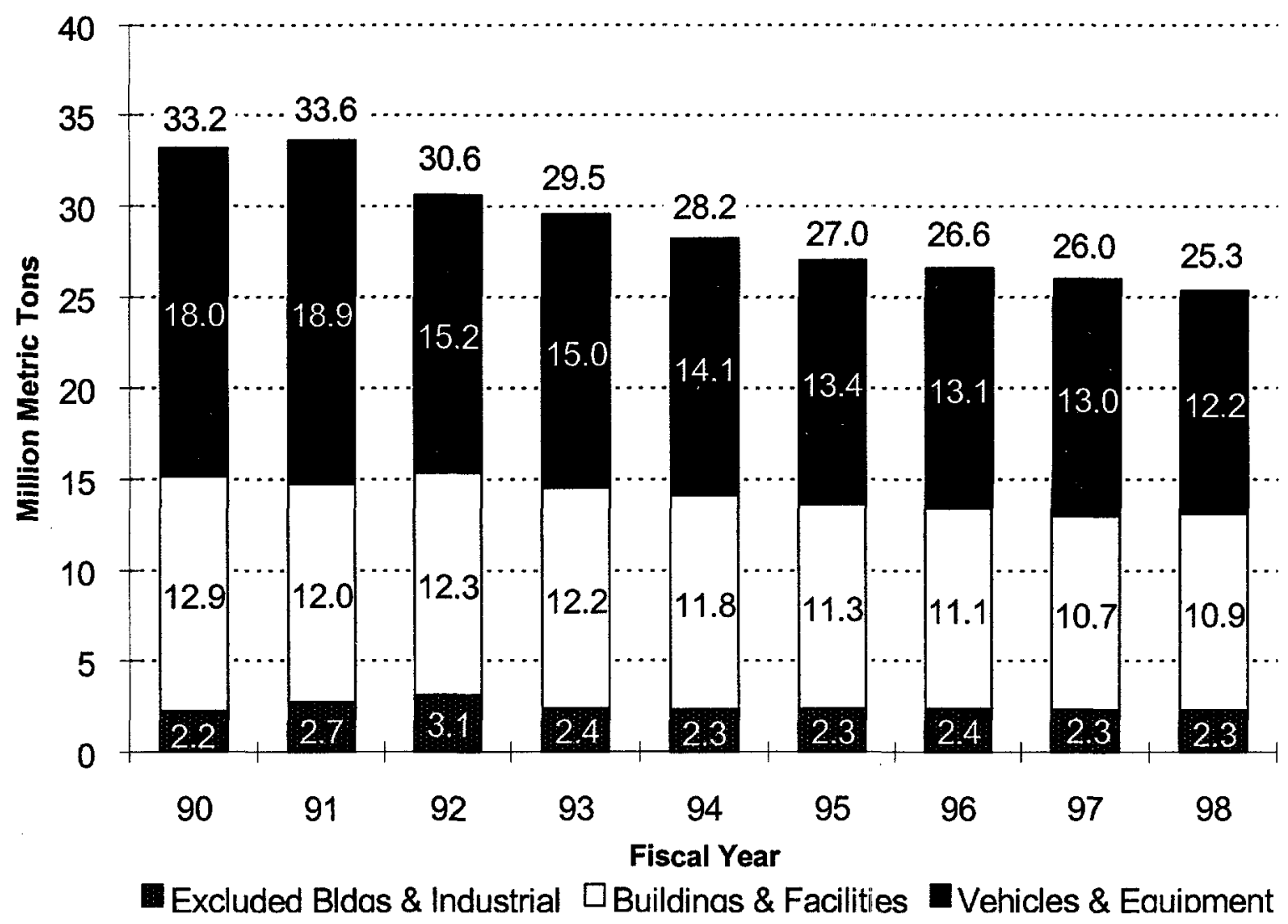

\footnotetext{
${ }^{10}$ Carbon emissions were calculated by multiplying energy consumption for each fuel type by an associated carbon coefficient shown in Appendix B. These coefficients are derived from DOE/EIA-0573(98), Emissions of Greenhouse Gases in the United States, 1998, October 1999; Tables 11 and B1.
} 


\section{Federal Coordination}

\section{Federal Interagency Energy Policy Committee ("656" Committee)}

The Federal Interagency Energy Policy Committee ("656" Committee) was established in accordance with Section 656 of the Department of Energy Organization Act (P.L. 95-91) to strengthen Government programs that emphasize productivity through the efficient use of energy, and concurrently, to encourage interagency cooperation in energy conservation. In mid FY 1997, the resignation of Christine Ervin, Assistant Secretary for Energy Efficiency and Renewable Energy and Chair for the " 656 " Committee, in combination with a number of other vacancies in "656" Committee members, led to the postponement of the meeting scheduled for May 14, 1997. The " 656 " Committee resumed its regular schedule in FY 1998 and convened a meeting on July 28,1998 . The following subjects were discussed:

- President Clinton's radio address in July 1998, which addressed the role of the Federal Government in tackling climate change. The announcement contained four initiatives related to Federal energy efficiency.

- The OMB memorandum which encourages the retention of savings from energy efficiency projects was discussed.

- The White House Climate Change Task Force, being used to implement energy policy, was described.

- A new, draft Charter was reviewed for the Federal Interagency Energy Policy Committee, which would include a detailed description of the Committee's role and responsibilities.

- A discussion was held about producing a guidance document regarding alternative financing. The guidance would answer common questions and help facility managers.

- Issues regarding renewable power purchasing were discussed, including White House guidance, GSA and Defense Logistics Agency procurement systems, and the renewable energy market.

- Federal Energy Saver Showcase plaques were presented to 27 Federal facilities.

\section{Federal Interagency Energy Management Task Force}

The Interagency Energy Management Task Force was established by section 547 of NECPA, as amended, 42 U.S.C. $\S 8257$. During the four meetings of the Task Force during FY 1998, the following subjects were examined and discussed:

December 16, 1997

- The results of hearings and budget actions were reported. 
- An announcement was made about the newly awarded Southeast Super Energy Savings Performance Contract.

- The Climate Change Initiative was discussed at length, emphasizing its importance to FEMP and the necessity for Federal agencies to report their contributions to reduction of carbon emissions using the energy consumption data already being reported by agencies.

- A report was given on the status of the Million Solar Roofs initiative.

- An announcement was made about the amendment of the Federal Acquisition Regulations, to include policy for agencies to implement cost-effective contracting preference programs favoring the acquisition of environmentally preferable and energyefficient products and services.

- The final versions of two alternative financing guidance memoranda approved by the Alternative Financing Guidance Committee were distributed. The memoranda cover Authority to Sole Source Utility Service Contracts, and Congressional Notification for Utility Projects.

- A presentation was given on the Washington State University Energy Program's Total Efficiency Network, which provides information, training, and support to public and private facilities to help them save money and resources through efficient resource management.

February 4, 1998

- A update was given on the status of the Super Energy Savings Performance Contract, including the announcement about the upcoming awards for the Super ESPC for the Central and Midwest regions.

- A report was given on the Task Force's Utility Restructuring Subcommittee's first meeting. The Subcommittee was formed to address the impact of restructuring of the electric utility industry on the Federal customer. The Task Force unanimously agreed on the Subcommittee continuing its direction.

- A description was given of the proposed language changes to the National Energy Conservation Policy Act to eliminate the FY 2000 sunset provision of the ESPC authority and address other contracting barriers.

- It was reported that an integrated renewable energy strategy is being developed to demonstrate Federal leadership in using cost-effective renewable energy technologies and provide strategic linkages among several programs, including renewable, alternative financing, Million Solar Roofs, FEMP deployment, and global climate change. 
- A draft report entitled "Issues Involved in Instituting Life Cycle Assessment for Federal Energy and Product Purchases" was distributed. The study concerns the inventory analysis component of LCA-the quantitative assessment of all the energy, materials, resources, and releases associated with the life-cycle of a product or processes, identified at each stage of the life-cycle.

- A presentation was given, entitled "Federal Energy Management in Buildings: Past and Future Carbon Trends."

April 14, 1998

- An update was given on the activities of the Barriers Subcommittee of the Renewable Energy Working Group.

- A brief overview was given on the "You Have the Power" energy awareness campaign.

A discussion was held regarding the Federal purchase of green power. It was decided that the Deregulation Subcommittee should investigate and make recommendations for a meeting on this issue in Bellevue, Washington as part of the Energy '98 trade show, and begin drafting a green power policy statement for 656 Committee approval.

- Draft guidance on choosing alternatives for acquiring private sector energy services was distributed. The guidance was drafted in response to a request from Congress resulting from the testimony of Secretary of Energy Peña on sole-source utility contracting. The Task Force was asked to comment on the guidance and provide their input.

- It was announced that FEMP is looking for sites in the Federal sector that would be good candidates for combined heat and power projects. Sites with the potential for cogeneration and district heating and cooling could receive technical assistance from FEMP in identifying projects.

- An overview of DOE's Office of Industrial Technologies' Inventions and Innovations Program was given. This program can provide a list of energy-saving technologies that have been tested by FEMP and are available for sale and/or test sites.

July 15,1998

- It was reported that the White House Climate Change Task Force has organized several working groups related to energy and requested additional volunteers for the working groups. The topics include: ESPCs; Energy-Efficient Procurement; Lights; Windows; Buildings for the $21^{\text {st }}$ Century; Transportation; and Executive Orders.

- An explanation of the goals of each working group was given, and it was noted that each working group had been charged with producing a summary of Federal Government efforts within their own area. 
- Reporting guidance for the FY 1998 Annual Report to Congress was distributed and discussed.

The complete minutes of these meetings are available from the DOE Federal Energy Management Program office.

\section{Personnel and Energy Awareness Activities}

\section{Training}

During FY 1998, DOE's Federal Energy Management Program (FEMP) conducted 49 training workshops and symposia for more than 5,100 attendees in the efficient use and conservation of energy, water, and renewable energy in Federal facilities.

FEMP supplemented its classroom workshops with "distance learning" training, via satellite. The Energy Management Teleworkshop, a 10-module survey of FEMP courses, attracted 2,400 viewers; the Utility Financing and the Utility Deregulation Impacts teleworkshops attracted 350 students each.

Eight workshops on energy savings performance contracting (ESPC) were conducted in FY 1998 for 241 participants. In each workshop, facility managers, contract specialists, and building engineers were instructed on the statutory provisions for this innovative contracting/financial method, and how to identify suitable projects. ESPC allows energy-efficient improvements to be installed by private contractors with no up-front capital costs.

The Designing Low Energy Buildings course was presented twice for 34 participants. The twoday course included analyses and case studies of building design using passive solar heating, natural ventilation and cooling, and day lighting, as well as glazing and overhangs.

The new FEMP Lights course was conducted twice for a total of 46 participants. The objective was to provide guidance on energy-efficient lighting consistent with other facility lighting considerations, quality and cost, and whole building analysis. Topics included: basic lighting concepts; a comprehensive process for Federal relighting project development and implementation; and the use of professional lighting design services.

Two Facility Energy Decision Screening (FEDS) workshops were held during FY 1998 for 30 attendees. This is a training course for Federal facility managers on whole-site analysis of energy conservation, technical, and financial opportunities utilizing the FEDS-Level 1 project screening software and the FEDS-Level 2 project implementation software.

The new FEMP Motor Training course, based on "Motor Master" software for buildings, was presented twice for 20 students.

Operations and Maintenance Management was presented once for 17 students. 
FEMP, in conjunction with the National Institute of Standards and Technology, conducted two workshops on life-cycle costing and building retrofit simulation for 73 students. The new Buying Energy-Efficient Products course was presented once for eight students.

The Implementing Renewable Energy Projects course was presented twice for 60 students.

FEMP continued to offer its Water Resource Management course with one workshop for eight attendees in FY 1998. The course is designed to assist Federal site managers and agencies in meeting the water conservation requirements of Energy Policy Act of 1992 (EPACT) and Executive Order 12902.

During FY 1998, FEMP participated in the organization and presentation of 20 panel discussions on Federal energy efficiency, water conservation, and renewable energy topics at national energy management conferences around the country, attracting 1,485 attendees.

The Federal Energy Management Program continued to offer its Training Course Locator System to assist Federal agencies in training energy managers and in meeting the requirements of the EPACT. The Jocator System connects those seeking particular training courses with the sponsoring organization for those courses by responding to numerous requests from Federal energy managers, utility managers, engineers, building operators, and facility personnel. 


\section{Recognition}

Outstanding accomplishments in energy efficiency and water conservation in the Federal sector were recognized with the presentation of the 1998 Federal Energy and Water Management Awards on October 28, 1998, at the National Press Club in Washington, D.C. The Awards Program is sponsored by the " 656 " Committee and the Department of Energy. Awards were selected from outstanding Federal energy managers and contributors who:

- Implemented proven energy efficiency, energy and water conservation techniques;

- Developed and implemented energy-related training programs and employee energy awareness programs;

- Succeeded in receiving utility incentives, or awarding ESPC and other Federal-approved performance-based energy and water contracts;

- Made successful efforts to fulfill compliance with energy and water reduction mandates; - Improved energy efficiency or reduction in energy costs for Federal mobile equipment including aircrafts, ships, and vehicles;

- Improved tracking of energy consumption, costs and energy efficient investments;

- Provided leadership in purchasing or supplying energy-efficient, renewable energy or water-conserving products to one or more Federal agencies; and

- Demonstrated cost-beneficial landscape practices which utilize techniques that seek to minimize the adverse effects of landscaping.

Recipients of the 1998 awards were selected from 188 nominees submitted by 17 Federal agencies. Award recipients totaled 49, representing 16 different Federal agencies. Distribution of awards among the Federal agencies for accomplishments in FY 1997 is indicated below. Awards were presented to agencies in the categories shown in the exhibit below:

\begin{tabular}{|c|c|c|c|c|c|c|c|c|c|c|}
\hline Agency & Individual & $\begin{array}{l}\text { Small } \\
\text { Group }\end{array}$ & Organization & Total & $\begin{array}{l}\text { Energy } \\
\text { Efficiency }\end{array}$ & $\begin{array}{l}\text { Alternative } \\
\text { Financing }\end{array}$ & $\begin{array}{c}\text { Renewable } \\
\text { Energy }\end{array}$ & Mobility & $\begin{array}{l}\text { Water } \\
\text { Mgmt. }\end{array}$ & $\begin{array}{l}\text { Exceptional } \\
\text { Service }\end{array}$ \\
\hline DOD & 1 & & & 1 & & & & & & 1 \\
\hline Army & 3 & & 1 & 4 & 2 & & 1 & & & 1 \\
\hline Navy & & & 9 & 9 & 5 & 1 & 3 & & & \\
\hline USAF & 1 & & 7 & 8 & 4 & 2 & & 1 & & 1 \\
\hline USMC & & & 1 & 1 & 1 & & & & & \\
\hline DOE & 2 & 3 & 2 & 7 & 4 & & 1 & & & 2 \\
\hline DOI & 2 & 1 & & 3 & & & 1 & 1 & 1 & \\
\hline DOJ & 1 & & & 1 & & & & & & 1 \\
\hline DOT & 1 & & & 1 & & & & & & 1 \\
\hline GSA & & 3 & 1 & 4 & 2 & 2 & & & & \\
\hline HHS & 1 & & & 1 & & & & & & 1 \\
\hline NASA & 1 & & & 1 & & & & & & 1 \\
\hline USDA & 1 & 1 & 1 & 3 & 2 & & & & & 1 \\
\hline USPS & 2 & 1 & & 3 & 2 & & & & & 1 \\
\hline DOC & & 1 & & 1 & & 1 & & & & \\
\hline State & & 1 & & 1 & 1 & & & & & \\
\hline TOTAL & 15 & 11 & 32 & 10 & ? & 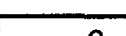 & 0 & 0 & 4 & 11 \\
\hline $101 \mathrm{AL}$ & 15 & 11 & 23 & 49 & 23 & 6 & 6 & 2 & 1 & 11 \\
\hline
\end{tabular}

Each category contained a wide variety of projects. Examples from each award category follow. 


\section{Energy Efficiency Award to Organization:}

Pacific Rim Region 9 Property Management Division, General Services Administration,San Francisco, California. The efforts at the Prince Jonah Kuhio Kalanianaole Federal Building and Courthouse in Hawaii utilized cutting edge technologies and high efficiency and productivity practices in upgrading the central cooling plant at this facility. The project required the replacement of two R-12, 1,000-ton centrifugal chillers and two R-11, 60-ton reciprocal chillers along with the associated pumps, motors, cooling towers, and controls. Initial project funds were cut by 50 percent due to pay for security upgrades in the wake of the Oklahoma City bombing, but an alliance with Hawaiian Electric Company enabled the project to go forward. The new plant consists of two 950-ton R-123 centrifugal chillers, one 200-ton centrifugal chiller, and a 60ton reciprocal R-22 chiller for emergency use. For the 10 month period starting June 1997 through March 1998, GSA saved 1.6 billion kilowatt hours or 5.6 billion Btu, a cost savings of $\$ 177,628$. After deducting the finance repayment costs, there was a net savings of $\$ 67,598$.

\section{Energy Efficiency Award to Small Group:}

William G. Jackson, Leslie Fish, Donald E. Garvin, William E. Watkins, Portland District, United States Postal Service, Portland, Oregon. The Portland District Energy Team has a remarkable track record, completing 167 energy saving projects from FY 1992 through FY 1997. Fifty-one of these projects were completed in FY 1997, saving 2.9 million kilowatt hours. The annual energy cost savings for the 51 projects completed during FY 1997 is almost $\$ 138,000$. The total first year energy cost savings for all 167 projects is $\$ 734,966$. The Energy Team has completed energy conservation projects on approximately 88 percent of their facility inventory.

\section{Energy Efficiency Award to Individual:}

Morgan Benson, $26^{\text {th }}$ Area Support Group, Department of the Army, Heidelberg, Germany. The $26^{\text {th }}$ Area Support Group (ASG) manages the $293^{\text {rd }}, 411^{\text {th }}$, and $415^{\text {th }}$ Base Support Battalions (BSBs) facilities in the U.S. Army Europe. While working in support of these facilities, Mr. Benson instituted a strong energy conservation program where none had previously existed. In FY 1996, two of the three Energy Conservation Investment Program (ECIP) projects submitted by Mr. Benson became the first-ever ECIP projects funded in Europe. In FY 1997 alone, the $26^{\text {th }}$ ASG reduced its energy consumption by 11 percent. Today, one ECIP project is complete, three are under construction, two are under design, and several are planned. As a direct result of Mr. Benson's efforts, the $26^{\text {th }}$ ASG has achieved annual savings of more than 48.7 billion Btu and avoided costs of $\$ 634,800$. The success of the 26 th ASG program has been achieved despite considerable mission-related activities.

\section{Energy Savings Performance Contracting Award:}

United States Air Force, Little Rock Air Force Base, Arkansas. Little Rock Air Force Base partnered with its providing utility, Energy Arkansas Inc., to design and install 1,535 geothermal ground source heat pumps in military family housing. The $\$ 10$ million project is the single largest demand side management effort ever undertaken in the Department of Defense. The process reduced the procurement cycle time and allowed Little Rock Air Force Base to execute needed infrastructure repair with no up-front capital investment. The project will result in an annual energy and maintenance savings in FY 1997 of more than \$1 million and a nearly 16 percent reduction in the Base's annual electricity usage. The ground source heat pump units were equipped with a de-superheater and attached to the hot water heaters. The de-superheater 
will supplement the heated water in the hot water heater while the new heat pump is running, thereby utilizing waste heat.

\section{Renewable Energy Award:}

Ivan D. Miller, Daniel W. Kreiber, David N. Ha, Paul J. LaValley, Frank Smith, Department of the Interior, National Park Service, Omaha, Nebraska. The team effort of the Sleeping Bear Dunes National Lakeshore and the National Park Service Midwest Support Office resulted implementing a sustainable power system that provides solar energy to North Manitou Island in Lake Michigan. This photovoltaic hybrid system replaced inefficient diesel generators and propane tanks. This new solar-powered system, complete with a battery bank for energy storage and backup diesel generators, has realized significant energy and environmental benefits including eliminating potential fuel spills, controlling air pollution emissions, and decreasing dependency on fossil fuels required to support the basic needs on the island. Solar power now supplies nearly all the electrical energy necessary for the island village from May through Labor Day, and approximately 90 percent of the energy for the entire year. The equipment investment for the North Manitou Island system was approximately $\$ 190,000$. The present value, on a 20year life-cycle cost for the hybrid system, is approximately $\$ 296,000$.

\section{Mobility Energy Management Award:}

USS MOBILE BAY (CG-53), Department of the Navy. USS Mobile Bay continued strict adherence to their Energy Conservation Program during FY 1997. This program, the crew's high level of energy awareness, and good engineering practices have all enabled Mobile Bay to achieve fuel savings of $\$ 2.7$ million over a three year period, with $\$ 1.4$ million in fuel cost savings in FY 1997. One of the activities responsible to this achievement is compliance with the trail shaft program while operating below $18 \mathrm{knots}$. This practice has cut fuel consumption between 30 and 45 percent. This translates to a fuel reduction of more than 325 gallons per hour, and more than 7,800 gallons per day. For FY 1997, 30,000 fewer barrels of fuel were consumed.

\section{Water Management Award:}

Central Federal Lands Highway Division and Coronado National Forest, Department of Transportation, Lakewood, Colorado, and U.S. Department of Agriculture, Tucson, Arizona. The Central Federal Lands Highway Division in cooperation with the Coronado National Forest has completed the fifth phase of reconstruction of the Hitchcock Highway, which runs 25 miles from Tucson, Arizona, to the top of the Santa Catalina Mountains. The intent of the project's landscaping practices was to integrate visual goals with safety and maintenance goals, and to ensure cost effectiveness of mitigation measures. Specialized blasting, staggered ridges and slopes; a four-prong revegetation approach using native plants; and a gravity-operated, drip irrigation system were all utilized. Cost benefits will result from reduced maintenance due to the use of natural rock fractures in blasting; using native plants with a high rate of survival; and the use of the low flow drip emitters, which provide a deep soak with a minimal water requirement.

\section{Exceptional Service Award:}

Phyllis E. Johnson, Agricultural Research Service, Department of Agriculture, Beltsville, Maryland. As Beltsville Area Director, Dr. Johnson provided support to the Beltsville Agricultural Research Center (BARC) in its energy awareness and conservation programs. Dr. Johnson was instrumental in the signing of an energy savings agreement with Washington Gas 
and Light Company, resulting in the installation of natural gas lines to the entire facility, eliminating the use of heating oil. Washington Gas and Light will pay the initial $\$ 700,000$ project cost. She also helped develop a state-of-the-art compost facility, eliminating the inflow of nitrogen and phosphorous to the Chesapeake Bay, resulting in a cost savings in excess of $\$ 70,000$ annually. The building consolidation program has resulted in savings of approximately $\$ 200,000$ per year in maintenance and utility costs. The Agricultural Research Center applied for Potomac Electric Power Company energy conservation rebates and recovered significant amounts on equipment, saving approximately $\$ 70,000$. The newly-constructed west side recycled water tank system will store effluent from the waste water treatment facility. The water will then be used for steam production, saving $\$ 40,000$ each year.

\section{Energy Awareness}

The Federal Government, as the largest single employer in the United States, has the responsibility to set an example for the nation by conducting energy awareness programs. Most agencies have ridesharing, carpooling, and/or public transportation programs in effect. Many agencies also participate in recycling programs. The following exhibit shows the employee awareness activities at the various Federal agencies.

\begin{tabular}{|c|c|c|c|c|c|}
\hline Agency & $\begin{array}{c}\text { Award } \\
\text { Programs }\end{array}$ & Recycling & Ridesharing & $\begin{array}{c}\text { Transit } \\
\text { Subsidies }\end{array}$ & $\begin{array}{c}\text { Information } \\
\text { Dissemination }\end{array}$ \\
\hline USDA & $\checkmark$ & $\checkmark$ & $\checkmark$ & & $\checkmark$ \\
\hline DOC & $\checkmark$ & $\checkmark$ & $\checkmark$ & & \\
\hline DOD & $\checkmark$ & $\checkmark$ & $\checkmark$ & $\checkmark$ & $\checkmark$ \\
\hline DOE & $\checkmark$ & $\checkmark$ & $\checkmark$ & $\checkmark$ & \\
\hline HHS & $\checkmark$ & $\checkmark$ & & & \\
\hline HUD & $\checkmark$ & $\checkmark$ & $\checkmark$ & $\checkmark$ & \\
\hline DOI & $\checkmark$ & $\checkmark$ & $\checkmark$ & $\checkmark$ & $\checkmark$ \\
\hline DOJ & $\checkmark$ & $\checkmark$ & $\checkmark$ & & $\checkmark$ \\
\hline DOL & $\checkmark$ & $\checkmark$ & $\checkmark$ & $\checkmark$ & \\
\hline ST & & $\checkmark$ & $\checkmark$ & & \\
\hline DOT & $\checkmark$ & $\checkmark$ & $\checkmark$ & $\checkmark$ & $\checkmark$ \\
\hline TRSY & & $\checkmark$ & $\checkmark$ & $\checkmark$ & $\checkmark$ \\
\hline VA & & $\checkmark$ & & & \\
\hline EPA & $\checkmark$ & $\checkmark$ & $\checkmark$ & $\checkmark$ & $\checkmark$ \\
\hline GSA & $\checkmark$ & $\checkmark$ & $\checkmark$ & & \\
\hline NASA & $\checkmark$ & $\checkmark$ & $\checkmark$ & $\checkmark$ & $\checkmark$ \\
\hline NARA & $\checkmark$ & & & & \\
\hline NRC & & $\checkmark$ & $\checkmark$ & $\checkmark$ & $\checkmark$ \\
\hline PCC & & & & & \\
\hline RRB & & $\checkmark$ & & $\checkmark$ & \\
\hline SSA & $\checkmark$ & $\checkmark$ & & & \\
\hline TVA & & $\checkmark$ & $\checkmark$ & & $\checkmark$ \\
\hline USPS & $\checkmark$ & $\checkmark$ & $\checkmark$ & $\checkmark$ & \\
\hline
\end{tabular}




\section{Federal Energy Saver Showcase Facilities}

Section 307 of Executive Order 12902 requires that each agency which constructs at least five buildings in a year shall designate at least one building, at the earliest stage of development, to be a showcase highlighting advanced technologies and practices for energy efficiency, water conservation, or use of solar and other renewable energy. Furthermore, it requires that the agencies attempt to incorporate cogeneration, solar and other renewable energy technologies, and indoor air quality improvements. Selection of such buildings is based on considerations such as the level of non-Federal visitors, historical significance, and the likelihood that visitors will learn from the demonstration and initiate similar projects. The Order charges each agency to develop and implement plans in cooperation with DOE and, where appropriate, in consultation with the General Services Administration, the Environmental Protection Agency, and other appropriate agencies to determine strategies to implement these demonstrations.

There were no showcase facilities designated in FY 1998. The showcase facilities designated in FY 1997 featured a wide variety of approaches and technologies at widely disparate Federal sites. Although many showcase projects carry out conventional energy saving measures, some also feature cutting-edge technologies. For example, GSA is partnering with their servicing utility and DOE to illuminate the exterior of the Alexander Hamilton Customs House with a sulfur lamp. The Department of Defense has designated three phosphoric fuel cell power plants as showcases. To date, these projects have saved the DOD nearly $\$ 250,000$, and have proven that fuel cells are a highly efficient, environmentally clean, and cost effective method of electricity generation. By installing this technology, DOD has taken the lead in increasing fuel cell use across the United States.

Twenty percent of the showcases have chosen geothermal technology to heat and cool their buildings. This technology is becoming more popular within the Federal sector, and is providing significantly lower utility bills to the energy managers at the Department of the Interior and the Department of Energy. No pollutants are added to the environment by these systems, and during their 20-year equipment life, geothermal heat pump systems save energy, dollars, and reduce emissions at a rate significantly lower than comparable heating and cooling systems.

Renewable energy technologies are also prominent. The Environmental Protection Agency's Ada and Narragansett Laboratories are integrating solar water heating technology. The passive solar design used in the Department of the Interior's Prairie Learning Center will save the Fish and Wildlife Service facility more than 400,000 kilowatt hours and \$17,000 in annual energy consumption. 


\section{E. Funding for Energy Efficiency in Buildings and Facilities}

During FY 1998, Federal agencies had three primary options for financing energy efficiency, water conservation, and renewable energy projects in buildings and facilities: direct appropriated funding, energy savings performance (ESP) contracts, and utility-sponsored demand side management (DSM) incentives. The latter two options utilize non-Government sources of funding and can be used to supplement Government funding. Each of these three sources can be combined with another. Formerly, the DOE's Federal Energy Efficiency Fund grant program was a fourth option available to agencies for funding projects; however, there were no appropriations for the Fund in FY 1998.

To the extent that agencies have been able to provide complete reporting, funding from the three sources totaled approximately $\$ 377$ million in FY 1998.

\section{Direct Appropriations}

The National Energy Conservation Policy Act requires each agency, in support of the President's annual budget request to Congress, to specifically set forth and identify funds requested for energy conservation measures. Table 3-A presents agency funding (in nominal dollars) reported from FY 1985 through FY 1998 for energy conservation retrofits and capital equipment. Table 3-B presents the same information in constant 1998 dollars. In constant dollars, funding for energy conservation declined from $\$ 371.0$ million in FY 1985 to a low of $\$ 65.6$ million in FY 1989. Reports from Federal agencies indicated that $\$ 261.3$ million was spent on retrofit expenditures in FY 1998, compared with $\$ 202.5$ million in FY 1997. In some cases, the data provided by the agencies include funding from operation and maintenance accounts that was specifically identified as contributing to energy efficiency. Figure 4 illustrates agency spending trends for the five largest energy-consuming agencies and the remaining group of Federal agencies.

The Defense Department funded $\$ 191.4$ million in expenditures for energy efficiency projects in FY 1998, \$71.3 million more than the previous year.

No direct funding was appropriated for the Department of Energy in FY 1998 for retrofit projects in buildings and metered process facilities. The General Services Administration also received no appropriations for energy efficiency projects in FY 1998. 
Table 3-A

Agency Expenditures for Energy Conservation Retrofits and Capital Equipment, FY 1985 through FY 1998 (Thousands of Nominal Dollars)

\begin{tabular}{|c|c|c|c|c|c|c|c|c|c|c|c|c|c|c|c|}
\hline & 1985 & 1986 & 1987 & 1988 & 1989 & 1990 & 1991 & 1992 & 1993 & 1994 & 1995 & 1996 & 1997 & 1998 & $\begin{array}{r}\text { Projected } \\
1999\end{array}$ \\
\hline DOC & 0 & 0 & 0 & 0 & 0 & 0 & 0 & 872 & 0 & 51 & 0 & 0 & NA & 330 & 1,015 \\
\hline DOD & 136,100 & 120,000 & 5,550 & 5,280 & 1,500 & 1,020 & 10,000 & 49,669 & 14,444 & 109,000 & 189,600 & 112,487 & 118,970 & 191,446 & 203,806 \\
\hline DOE & 14,800 & 14,500 & 16,500 & 18,900 & 19,400 & 19,500 & 20,400 & 20,650 & 20,950 & 24,850 & 30,200 & 0 & 0 & 0 & 0 \\
\hline DOI & 3,198 & 5,535 & 0 & 0 & 4,338 & 0 & 1,272 & 9,800 & 4,859 & 1,662 & 779 & 891 & 0 & 160 & 176 \\
\hline DOJ & 0 & 0 & 0 & 195 & 484 & 6,100 & 26,400 & 0 & $N / A$ & 1,284 & 994 & 1,559 & 2,091 & 1,500 & 1,700 \\
\hline DOL & 238 & 31 & 106 & 142 & 584 & 17 & 35 & 16 & 0 & 0 & N/A & 366 & 0 & 0 & 0 \\
\hline DOT & 13,650 & 15,000 & 12,104 & 12,700 & 2,908 & 0 & 460 & 143 & 593 & 5,970 & 3,793 & 2,585 & 3,176 & 3,000 & 3,000 \\
\hline EPA & 0 & 0 & 0 & 0 & 0 & 0 & 0 & 0 & 500 & 0 & 1,720 & 1,600 & 1,600 & 0 & 0 \\
\hline GSA & 6,700 & 6,100 & 2,900 & 9,400 & 4,868 & 11,125 & 30,123 & 37,000 & 30,000 & 37,000 & 7,242 & 7,400 & 20,000 & 0 & 1,860 \\
\hline HHS & 0 & 0 & 0 & 427 & 427 & 427 & 427 & 0 & 1,813 & 1,915 & 1,271 & 2,676 & 2,879 & 2,200 & 3,295 \\
\hline HUD & 0 & 0 & 0 & 0 & 0 & 0 & 0 & 0 & 43 & 30 & 43 & 0 & 2,418 & 0 & 0 \\
\hline NASA & 11,800 & 12,100 & 1,700 & 1,400 & 4,499 & 2,943 & 7,556 & 7,086 & 25,072 & 24,658 & 20,666 & 30,266 & 15,919 & 13,813 & 13,695 \\
\hline PCC & 1,274 & 73 & 1,174 & 600 & 378 & 361 & 807 & 249 & 500 & 608 & 14 & 23 & 3 & 104 & 0 \\
\hline RRB & 0 & 0 & 0 & 0 & 0 & 0 & 0 & 0 & 16 & 13 & 33 & 0 & 38 & 23 & 0 \\
\hline STATE & 0 & 0 & 0 & 0 & 0 & 0 & 0 & 0 & 0 & 67 & 0 & 0 & 1,902 & 51 & 0 \\
\hline TRSY & 0 & 0 & 2,977 & 2,393 & 2,823 & 1,134 & 836 & 0 & 1,344 & 4,826 & 2,810 & 170 & 2,990 & 1,400 & 300 \\
\hline TVA & 0 & 0 & 0 & 0 & 0 & 0 & 0 & 0 & 475 & 844 & 4,277 & 522 & 1,158 & 1,466 & 700 \\
\hline USDA & 2,500 & 0 & 0 & 500 & 500 & 1,547 & 1,752 & 7,300 & 7,045 & 7,277 & 2,894 & 5,983 & 3,891 & 1,765 & 0 \\
\hline USPS & 55,300 & 9,300 & 5,100 & 3,800 & 4,000 & 4,000 & 4,000 & 2,293 & 1,116 & 1,123 & 10,050 & 9,000 & 16,000 & 31,000 & 30,000 \\
\hline VA & 13,000 & 11,500 & 9,500 & 9,860 & 5,500 & 11,200 & 9,970 & 10,000 & 12,100 & 9,050 & 11,960 & 3,700 & 7,400 & 13,000 & 15,000 \\
\hline Total & 258,560 & 194,139 & 57,611 & 65,597 & 52,209 & 59,374 & 114,038 & 145,078 & 120,870 & 230,228 & 288,346 & 179,228 & 200,435 & 261,258 & 274,547 \\
\hline
\end{tabular}

Source: Federal Agency Annual Energy Management Data Reports 
Table 3-B

Agency Expenditures for Energy Conservation Retrofits and Capital Equipment, FY 1985 through FY 1998 (Thousands of Constant 1998 Dollars)

\begin{tabular}{|c|c|c|c|c|c|c|c|c|c|c|c|c|c|c|c|}
\hline & 1985 & 1986 & 1987 & 1988 & 1989 & 1990 & 1991 & 1992 & 1993 & 1994 & 1995 & 1996 & 1997 & 1998 & $\begin{array}{r}\text { Projected } \\
1999\end{array}$ \\
\hline DC & 0 & $\begin{array}{r}0 \\
72929\end{array}$ & $\begin{array}{r}0 \\
7524\end{array}$ & 0 & 0 & 0 & $\begin{array}{r}0 \\
0\end{array}$ & 983 & $\begin{array}{r}0 \\
0707\end{array}$ & 55 & 0 & 0 & 0 & 330 & $\begin{array}{r}1,005 \\
\end{array}$ \\
\hline OD & 5,265 & 7,832 & 7,531 & 6,911 & 1,884 & 1,227 & 11,587 & 55,997 & 15,873 & 116,827 & 198,742 & 115,727 & 120,172 & 191,446 & 201,788 \\
\hline $\mathrm{OE}$ & 1,234 & 20,280 & 2,388 & 24,738 & 24,372 & 23,466 & 23,638 & 3,281 & 23,022 & 26,635 & 31,656 & 0 & 0 & 0 & 0 \\
\hline 이 & 4,588 & 741 & 0 & 0 & 5,450 & 0 & 1,474 & 11,048 & 5,340 & 1,781 & 817 & 917 & 0 & 160 & 174 \\
\hline ) & 0 & 0 & 0 & 255 & 608 & 7,341 & 30,591 & & 0 & 1,376 & 1,042 & 1,604 & 2,112 & 1,500 & 1,683 \\
\hline $\mathrm{Jt}$ & 341 & 43 & 144 & 186 & 734 & 20 & 41 & 18 & 0 & & 0 & 7 & & 0 & 0 \\
\hline 1 & 19,584 & 20,979 & 16,423 & 16,623 & 3,653 & 0 & 533 & 161 & 651 & 6,399 & 3,976 & 2,65 & 3,208 & 3,000 & 2,970 \\
\hline$r$ & 0 & 0 & 0 & 0 & 0 & 0 & 0 & 0 & 549 & 0 & 1,803 & 1,646 & 1,616 & 0 & 0 \\
\hline 9 & 9,613 & 8,531 & 3,935 & 12,304 & 6,116 & 13,387 & 34,905 & 41,714 & 32,967 & 39,657 & 7,591 & 7,613 & 20,202 & 0 & 1,842 \\
\hline$A S$ & 0 & 0 & 0 & 559 & 536 & 514 & 495 & 0 & 1,992 & 2,053 & 1,332 & 2,753 & 2,908 & 2,200 & 3,262 \\
\hline & 0 & 0 & 0 & 0 & 0 & 0 & 0 & 0 & 47 & 32 & 45 & 0 & 2,442 & 0 & 0 \\
\hline AS & 16,930 & 16,923 & 2,307 & 1,832 & 5,652 & 3,542 & 8,756 & 7,989 & 27,552 & 26,429 & 21,662 & 31,138 & 16,080 & 13,813 & 13,559 \\
\hline 1 & 1,828 & 102 & 1,593 & 785 & 475 & 434 & 935 & 281 & 549 & 652 & 15 & 24 & 3 & 104 & 0 \\
\hline$P P_{2}$ & 0 & 0 & 0 & 0 & 0 & 0 & 0 & 0 & 18 & 14 & 35 & 0 & 38 & 23 & 0 \\
\hline$A$ & 0 & 0 & 0 & 0 & 0 & 0 & 0 & 0 & 0 & 72 & 0 & 0 & 1,921 & 51 & 0 \\
\hline 25 & 0 & 0 & 4,039 & 3,132 & 3,546 & 1,365 & 969 & 0 & 1,477 & 5,173 & 2,945 & 175 & 3,020 & 1,400 & 297 \\
\hline & 0 & 0 & 0 & 0 & 0 & 0 & 0 & 0 & 522 & 905 & 4,483 & 5 & 1,170 & & 693 \\
\hline USD & 3,587 & 0 & 0 & 654 & 628 & 1,862 & 2,030 & 8,230 & 7,742 & 7,800 & 3,034 & 6,15 & 3,930 & 1,765 & 0 \\
\hline USPS & 79,340 & 13,007 & 6,920 & 4,974 & 5,025 & 4,813 & 4,635 & 2,585 & 1,227 & 1,204 & 10,535 & 9,259 & 16,162 & 31,000 & 29,703 \\
\hline $\mathbf{A}$ & 18,651 & 16,084 & 12,890 & 12,906 & 6,910 & 13,478 & 11,553 & 11,274 & 13,297 & 9,700 & 12,537 & 3,807 & 7,475 & 13,000 & 14,851 \\
\hline otal & 370,961 & 271,523 & 78,170 & 85,860 & 5,589 & 71,449 & 132,141 & 163,560 & 132,825 & 246,761 & 302,249 & 184,391 & 202,459 & 261,258 & 271,829 \\
\hline
\end{tabular}

Notes: Bold indicates top five energy users in buildings and facilities (DOD, DOE, VA, USPS, GSA). In past years, DOE also included funds for energy surveys. Does not include energy savings performance contracts and utility demand side management incentives.

Source: Federal Agency Annual Energy Management Data Reports 
FIGURE 4

Energy Conservation Retrofit Expenditures

(In Constant 1998 Dollars)

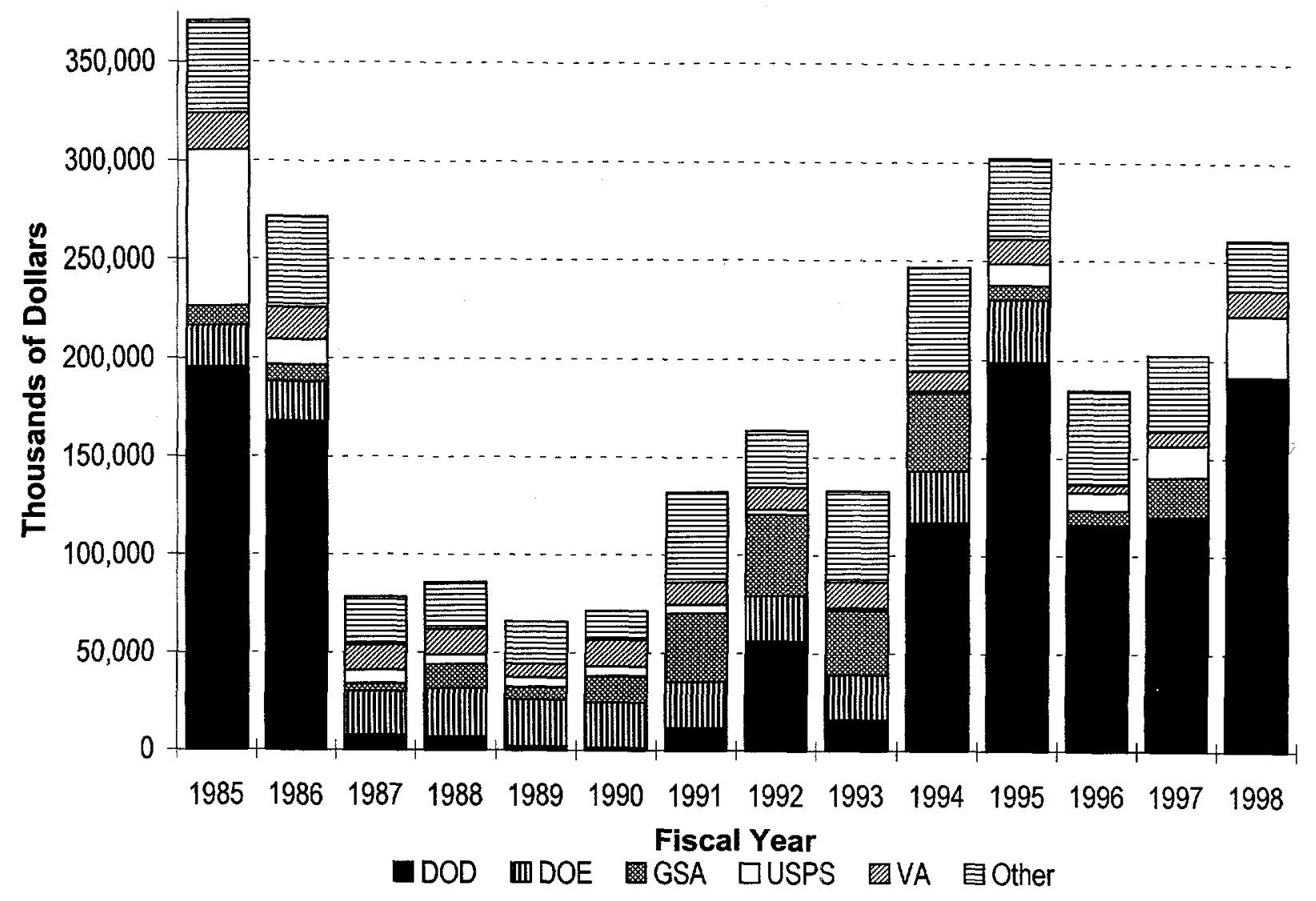

Source: Federal Agency Annual Energy Management Data Reports 


\section{Federal Energy Efficiency Fund}

The Federal Energy Efficiency Fund (Fund) was established by section 152 of EPACT, which amended section 546 of NECPA, to provide grants to agencies to assist them in meeting the mandated energy efficiency and water conservation requirements. The limited spending authority available in FY 1994 and FY 1995 was applied to those proposals which were most competitive, considering the five following factors:

1. The cost-effectiveness of the project (saving-to-investment ratio).

2. The net dollar cost savings to the Federal Government.

3. The amount of energy savings to the Federal Government.

4. The amount of funding committed by the agency requesting financial assistance.

5. The amount of funding leveraged from non-Federal sources.

No spending authority has been provided beyond FY 1995. A total of 114 proposals were received during FY 1994 and FY 1995 and Fund grants were provided for 37 projects. Of these, 35 projects provide energy savings of 5.8 trillion Btu and two projects result in water conservation in the amount of 738 million cubic feet, with an estimated energy and water cost savings of $\$ 54$ million (before payback of the initial investment) over the useful lives of the projects. The total Fund investment to realize these savings was $\$ 7.9$ million, which leveraged $\$ 3.6$ million in Federal-agency funding and \$0.9 million in non-Federal funding. The projects encompass 14 states and the District of Columbia, with one project located in the Caribbean. A summary of the funded projects is shown on the next page.

EPACT, 42 U.S.C. $\S 8258$, requires energy and cost savings to be reported annually after completion of construction, for each project funded under the Federal Energy Efficiency Fund. Of the 37 funded projects, 25 are complete and operational, realizing annual energy and cost savings which equal or exceed the values projected in the original proposals for Fund grants. Six energy efficient lighting projects, two water projects, and one each HVAC, chiller, and natural gas conversion projects remain under construction for completion by the end of FY 1998. These projects have been integrated into other non-Fund building upgrades funded by the respective agencies, resulting in longer time periods required for completion. In some cases, mission requirements have also limited building access.

Three Federal Energy Efficiency Fund projects will each put in place one base-wide energy savings performance contract (ESPC) for the U.S. Coast Guard in Honolulu, HI, and the National Park Service for the Presidio of San Francisco, CA, and two ESPCs will be put in place for the U.S. Army at Fort Huachuca, AZ. One of the Fort Huachuca projects and the U.S. Coast Guard project will install renewable energy solar hot water systems. 


\section{Federal Energy Efficiency Fund Projects - FY 1998 Status}

\begin{tabular}{|c|c|c|c|c|}
\hline (8) & State & 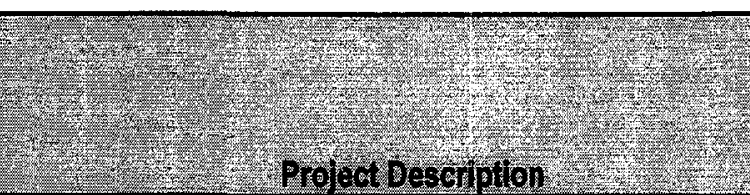 & 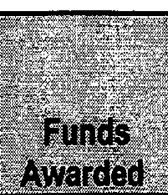 & 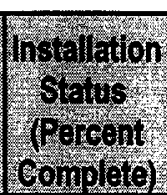 \\
\hline DOC - NOAA & WA & NW Fish Science Center - Fish Culture System & $\$ 471,399$ & $98 \%$ \\
\hline DOD - US Army & $A Z$ & Solar and Base-wide Upgrades & $\$ 310,000$ & $15 \%$ \\
\hline DOI - National Park Service & UT & Dangling Rope Marina - PV System & $\$ 350,000$ & $100 \%$ \\
\hline DOI - National Park Service & $\overline{D C}$ & White House - Transformer \& NPS Detailee & $\$ 74,000$ & $100 \%$ \\
\hline DOI - National Park Service & WY & Yellowstone NP - Lighting, Heat, \& Insulation & $\$ 455,665$ & $100 \%$ \\
\hline DOl - National Park Service & $W Y$ & Yellowstone NP - Phase 2 Lighting, Heat, \& Insulation & $\$ 174,500$ & $95 \%$ \\
\hline DOI - National Park Service & $\mathrm{CA}$ & Channel Island Santa Rosa Island - Wind \& PV System & $\$ 272,394$ & $95 \%$ \\
\hline DOI - National Park Service & $\mathrm{CA}$ & Yosemite National Park - Lighting Retrofit & $\$ 73,621$ & $80 \%$ \\
\hline DOI - National Park Service & $\mathrm{CA}$ & Golden Gate NRA, Presidio - Lighting Retrofit & $\$ 175,000$ & $50 \%$ \\
\hline DOL - Job Corps Center & MT & Electric to Natural Gas Conversion & $\$ 225,000$ & $100 \%$ \\
\hline DOT - FAA & $\mathrm{OH}$ & Lighting Retrofit & $\$ 103,706$ & $100 \%$ \\
\hline DOT - Coast Guard & AK & Used Oil Processing Facility & $\$ 530,000$ & $100 \%$ \\
\hline DOT - Coast Guard & $M D$ & USCG Yard, Lighting Retrofit & $\$ 80,671$ & $100 \%$ \\
\hline DOT - Coast Guard & $\mathrm{HI}$ & Housing Area - Solar Water Heating & $\$ 100,000$ & $22 \%$ \\
\hline Treasury - US Mint & PA & Lighting Retrofit & $\$ 103,180$ & $100 \%$ \\
\hline Exec. Residence Agency & $\mathrm{DC}$ & White House - Lighting Retrofit \& Refrigerator & $\$ 50,477$ & $100 \%$ \\
\hline HHS - NIH/National Cancer Inst. & $M D$ & Chiller Installation & $\$ 283,463$ & $56 \%$ \\
\hline HHS - NIH/National Cancer Inst. & MD & Occupancy Sensor Installation & $\$ 129,090$ & $7 \%$ \\
\hline NASA - Dryden & $\mathrm{CA}$ & Edwards AFB Bldg \#4800 Lighting Retrofit & $\$ 265,414$ & $100 \%$ \\
\hline NASA - Goddard & MD & Bldg's \#17, 21, 22, \& 23 Lighting Retrofit & $\$ 286,715$ & $100 \%$ \\
\hline NASA - Goddard & $M D$ & E-Building Complex Lighting Retrofit & $\$ 94,812$ & $100 \%$ \\
\hline NASA - Kennedy & $\mathrm{FL}$ & Bldg M7-505 Lighting Retrofit & $\$ 144,500$ & $100 \%$ \\
\hline NASA - Kennedy & $F L$ & Bldg M6-336 Lighting \& HVAC Retrofits & $\$ 41,800$ & $100 \%$ \\
\hline NASA - Kennedy & $\mathrm{FL}$ & Bldgs M6-339 \& M7-581 Lighting Retrofit & $\$ 36,942$ & $100 \%$ \\
\hline NASA - Kennedy & $\mathrm{FL}$ & Hanger L, Bldg 1732 Lighting \& HVAC Mods & $\$ 88,900$ & $100 \%$ \\
\hline NASA - Kennedy & $\mathrm{FL}$ & Launch Complex 39 Lighting Retrofit & $\$ 106,050$ & $100 \%$ \\
\hline NASA - Marshall & $\mathrm{AL}$ & Bldg. 4610 Lighting Modifications & $\$ 120,000$ & $91 \%$ \\
\hline NASA - Marshall & $\mathrm{AL}$ & Building 4250 Water Conservation & $\$ 116,500$ & $91 \%$ \\
\hline National Gallery of Art & $D C$ & HVAC Automation System & $\$ 2,000,000$ & $95 \%$ \\
\hline Smithsonian Institution & $\mathrm{MD}$ & Support Center - Phases 3, 4, \& 5 Lighting & $\$ 100,000$ & $100 \%$ \\
\hline Agency for Int'I Development & Jamaica & Executive Office Bldg - Lighting \& Windows & $\$ 69,798$ & $100 \%$ \\
\hline USDA - Agric. Research Service & MD & Bldg 011A - Fluorescent Lamp Retrofit & $\$ 3,640$ & $100 \%$ \\
\hline USDA - Agric. Research Service & $\mathrm{MD}$ & Bldg 011A - Lighting Occupancy Sensors & $\$ 33,326$ & $100 \%$ \\
\hline USDA - Forest Service & $A Z$ & Apache-Sitgreaves NF Lighting Retrofit & $\$ 35,000$ & $100 \%$ \\
\hline USDA - Forest Service & $A Z$ & Kaibab NF - Replace Telephone Switch & $\$ 66,500$ & $100 \%$ \\
\hline USDA - Forest Service & $\mathrm{CA}$ & Shasta-Trinity NF - NCSC Lighting Retrofit & $\$ 28,500$ & $100 \%$ \\
\hline US Soldiers \& Airmen's Home & $\mathrm{DC}$ & Lighting Retrofit & $\$ 274,677$ & $100 \%$ \\
\hline
\end{tabular}




\section{Energy Savings Performance Contracting}

Section 155 of EPACT amended Title VIII of NECPA, sections 801 and 804, relating to energy savings contracts. Section 801 , as amended, gives agencies the authority to enter into energy savings performance contracts (ESPCs) and describes the methodology of contract implementation. The ESPC program was created to provide agencies with a quick and costeffective way to increase the energy efficiency of Federal buildings. Under an ESPC, a private sector energy service company (ESCO) will assume the capital costs of installing energy and water conservation equipment and renewable energy systems. The ESCO guarantees the agency a fixed amount of energy cost savings throughout the life of the contract and is paid directly from those cost savings. Agencies retain the remainder of the energy cost savings.

On April 10, 1995, DOE published in the Federal Register (10 CFR Part 436) a final rule that sets forth the regulations for energy savings performance contracting and achieved the directive to substitute regulations for certain provisions in the FAR. On April 18, 1995, DOE published a correction that changed the effective date of the final rule from May 10 to April 10, 1995.

An application process for a Qualified List of ESCOs was also released with the ESPC regulations. Only firms on the Qualified List may receive an ESPC award. Firms that wish to be on the Qualified List must submit an application to DOE and possess the required experience and expertise. The List is continually updated.

On November 2, 1998, the Energy Conservation Reauthorization Act was signed by the President to become Public Law 105-388. The law makes several significant changes to EPACT and NECPA. Section 4 of Public Law 105-388 amends NECPA section 801 to extend the authority of Federal agencies to enter into ESPCs through September 30, 2003. Without this amendment, the authority would have expired on April 10,2000. Section 4 also amends the definition of "Federal agency" in NECPA Section 804 to include each authority of the U.S. Government, whether or not it is within or subject to review by another agency. During the reauthorization process, the House Committee on Commerce reported that ESPCs have "tremendous potential to produce significant energy savings at Federal facilities," utilizing the resources and capital of private industry.

Inherent to implementation of the ESPC regulation is the necessity for action by senior agency officials, agency priority on employing ESPCs, development and maintenance of trained and dedicated procurement personnel, and accountability for results.

During FY 1998, 35 conventional ESPCs were awarded that, in total, are worth at least $\$ 79$ million, providing the Government with an opportunity to save millions of dollars in energy costs during the life of the contracts. These ESPCs include eight by the U.S. Postal Service, two each by the Department of the Treasury, the Department of Transportation, and the National Aeronautic and Space Administration, and one each by the Department of Energy, Department of State, and the Environmental Protection Agency. 


\section{Conventional Energy Savings Performance Contracts Awarded by Civilian Agencies in FY 1998}

\begin{tabular}{|c|c|c|c|}
\hline Project Name/Location & Project Description & $\begin{array}{l}\text { Contractor Investment } \\
\text { or Contract Value }\end{array}$ & Savings \\
\hline $\begin{array}{l}\text { Dept. of Energy, Savannah } \\
\text { River Operations Office, } \\
\text { Aiken, South Carolina }\end{array}$ & $\begin{array}{l}\text { Lighting retrofits, HVAC, } \\
\text { variable frequency drives, } \\
\text { energy-efficient motors, and } \\
\text { energy management and } \\
\text { control system }\end{array}$ & $\begin{array}{l}\text { Contractor investment } \\
\text { for 1st task order is } \\
\text { estimated at } \$ 1.8 \mathrm{M}\end{array}$ & $\begin{array}{l}\text { 1st year savings } \\
\text { estimated at } \$ 291,648\end{array}$ \\
\hline $\begin{array}{l}\text { Dept. of State, Office of } \\
\text { Foreign Buildings } \\
\text { Operations, Mexico City, } \\
\text { Mexico }\end{array}$ & Lighting and $\mathrm{HVAC}$ retrofits & $\begin{array}{l}\text { Contract value is } \\
\$ 593,557\end{array}$ & $\begin{array}{l}\text { Expected annual savings } \\
\text { are } \$ 67,000\end{array}$ \\
\hline $\begin{array}{l}\text { Dept. of Transportation, } \\
\text { Research and Special } \\
\text { Programs Administration, } \\
\text { Cambridge, Massachusetts }\end{array}$ & $\begin{array}{l}\text { Lighting retrofit and energy } \\
\text { management system }\end{array}$ & $\mathrm{TBD}$ & TBD \\
\hline $\begin{array}{l}\text { Dept. of Transportation, } \\
\text { U.S. Coast Guard, USCG } \\
\text { Academy, New London, } \\
\text { Connecticut }\end{array}$ & $\begin{array}{l}\text { Comprehensive energy } \\
\text { improvements }\end{array}$ & TBD & TBD \\
\hline $\begin{array}{l}\text { Dept. of the Treasury, U.S. } \\
\text { Mint, Denver, Colorado and } \\
\text { San Francisco, California }\end{array}$ & $\begin{array}{l}\text { Lighting retrofits, chiller } \\
\text { replacements, HVAC } \\
\text { upgrades, and compressed } \\
\text { air system upgrades }\end{array}$ & $\begin{array}{l}\text { Total contract value of } \\
\text { the two ESPCs is } \\
\$ 1.688 \mathrm{M}\end{array}$ & $\begin{array}{l}\text { Anticipated annual } \\
\text { savings of } \$ 192,300 \text { and } \\
1,474 \text { megawatt-hours }\end{array}$ \\
\hline $\begin{array}{l}\text { EPA, National Vehicle and } \\
\text { Fuel Emissions Laboratory, } \\
\text { Ann Arbor, Michigan }\end{array}$ & $\begin{array}{l}\text { HVAC retrofit, heating and } \\
\text { cooling plant upgrade, } \\
\text { energy management and } \\
\text { control system, efficient } \\
\text { motors, } 200 \mathrm{~kW} \text { fuel cell }\end{array}$ & $\begin{array}{l}\text { Contract value is more } \\
\text { than } \$ 21 \mathrm{M}\end{array}$ & $\begin{array}{l}\text { Energy consumption will } \\
\text { be reduced by } 66 \% \text {, } \\
\text { energy costs by } 74 \% \text {, } \\
\text { water consumption by } \\
15 \%\end{array}$ \\
\hline $\begin{array}{l}\text { NASA, Goddard Space } \\
\text { Flight Center, Greenbelt, } \\
\text { Maryland; and Wallops } \\
\text { Flight Facility, Wallops } \\
\text { Island, Virginia }\end{array}$ & $\begin{array}{l}\text { Lighting retrofits, LED exit } \\
\text { signs, and other technologies }\end{array}$ & $\begin{array}{l}\text { Two IDIQ contracts } \\
\text { with a maximum value } \\
\text { of } \$ 5 \mathrm{M} \text { each }\end{array}$ & TBD \\
\hline USSPS, Louisville, Kentucky & $\begin{array}{l}\text { Comprehensive energy } \\
\text { improvements }\end{array}$ & $\begin{array}{l}\$ 750,000 \text { investment in } \\
5 \text { facilities }\end{array}$ & $\begin{array}{l}\text { Annual savings of } \\
\$ 100,000\end{array}$ \\
\hline $\begin{array}{l}\text { USPS, Eastern Shore, } \\
\text { Maryland }\end{array}$ & $\begin{array}{l}\text { Comprehensive energy } \\
\text { improvements }\end{array}$ & $\begin{array}{l}\$ 10.8 \mathrm{M} \text { investment in } \\
111 \text { facilities }\end{array}$ & TBD \\
\hline USPS, Baltimore, Maryland & $\begin{array}{l}\text { Comprehensive energy } \\
\text { improvements }\end{array}$ & $\begin{array}{l}\$ 21.27 \mathrm{M} \text { investment in } \\
41 \text { facilities }\end{array}$ & TBD \\
\hline USPS, Dallas, Texas & $\begin{array}{l}\text { Comprehensive energy } \\
\text { improvements }\end{array}$ & $\begin{array}{l}\$ 1.824 \mathrm{M} \text { investment in } \\
8 \text { facilities }\end{array}$ & $\begin{array}{l}\text { Annual savings of } \\
\$ 316,000\end{array}$ \\
\hline
\end{tabular}




\begin{tabular}{|l|l|l|l|}
\hline \multicolumn{1}{|c|}{ Project Name/Location } & \multicolumn{1}{|c|}{ Project Description } & $\begin{array}{l}\text { Contractor Investment } \\
\text { or Contract Value }\end{array}$ & \multicolumn{1}{|c|}{ Savings } \\
\hline $\begin{array}{l}\text { USPS, Oklahoma City, } \\
\text { Oklahoma }\end{array}$ & $\begin{array}{l}\text { Comprehensive energy } \\
\text { improvements }\end{array}$ & $\begin{array}{l}\$ 4.7 \mathrm{M} \text { investment in one } \\
\text { facility }\end{array}$ & $\begin{array}{l}\text { Annual savings of } \\
\$ 247,000\end{array}$ \\
\hline USPS, Tampa, Florida & $\begin{array}{l}\text { Comprehensive energy } \\
\text { improvements }\end{array}$ & $\begin{array}{l}\$ 2.2 \mathrm{M} \text { investment in } \\
260 \text { facilities }\end{array}$ & $\begin{array}{l}\text { Annual savings of } \\
\$ 940,000\end{array}$ \\
\hline USPS, Atlanta, Georgia & $\begin{array}{l}\text { Comprehensive energy } \\
\text { improvements }\end{array}$ & $\begin{array}{l}\$ 400,000 \text { investment in } \\
\text { two facilities }\end{array}$ & $\begin{array}{l}\text { Annual savings of } \\
\$ 80,000\end{array}$ \\
\hline $\begin{array}{l}\text { USPS, Birmingham, } \\
\text { Alabama }\end{array}$ & $\begin{array}{l}\text { Comprehensive energy } \\
\text { improvements }\end{array}$ & $\begin{array}{l}\$ 1.5 \mathrm{M} \text { investment in } 27 \\
\text { facilities }\end{array}$ & $\begin{array}{l}\text { Annual savings of } \\
\$ 294,000\end{array}$ \\
\hline
\end{tabular}

Also during FY 1998, the Department of Defense awarded six regional ESPCs, including coverage of the Caribbean and Guam. DOD also awarded 18 separate ESPCs and issued four delivery orders. Anticipated annual savings from the awarded contracts and delivery orders is $\$ 8$ million and 295 trillion Btu.

In July 1998, President Clinton directed Federal agencies to work more closely with private contractors to retrofit Federal buildings with the best energy-saving technologies at no cost to the taxpayer. Awarding ESPCs on a one-by-one basis has often proven to be complex and time consuming. To make it easier to use ESPCs, DOE's Federal Energy Management Program (FEMP) has developed Regional and Technology-Specific Super ESPCs. Both Regional and Technology-Specific Super ESPCs share the same general contract terminology and provisions with conventional ESPCs and they present several significant advantages to Federal agencies.

Super ESPCs are unlike conventional ESPCs in two fundamental ways. First, a Super ESPC blankets a large geographic territory; a conventional ESPC is used for a specific site. The second, and real benefit to agencies, is that Super ESPCs substantially reduce the lead time to contract with an energy savings company (ESCO) for energy services. Super ESPCs are broad area indefinite delivery, indefinite quantity (IDIQ) contracts that allow agencies to negotiate sitespecific delivery orders with an ESCO without having to start the contracting process from scratch. Demand on agency resources to develop and award contracts, as well as lead times, will be greatly reduced, and energy savings will be realized more quickly.

The first Regional Super ESPC covers the Western Region and was awarded to five ESCOs in May 1997. During FY 1998, three more Regional awards were made. On January 12, 1998, the Southeast Regional Super ESPC, covering Alabama, Arkansas, Florida, Georgia, Kentucky, Mississippi, North Carolina, South Carolina, Tennessee, Puerto Rico, and the U.S. Virgin Islands, was awarded to six ESCOs (CES/Way International, DukeSolutions, Energy Masters Corporation, ERI Services, Johnson Controls, and Honeywell). On July 25, 1998, the Midwest Regional Super ESPC, covering Illinois, Indiana, Iowa, Michigan, Minnesota, Missouri, Ohio, and Wisconsin was awarded to six ESCOs (DukeSolutions, Energy Pacific, ERI Services, Johnson Controls, NORESCO, and EUA Cogenex). Also on July 25, 1998, the Central Regional Super ESPC, covering Colorado, Kansas, Louisiana, Montana, Nebraska, New Mexico, North Dakota, Oklahoma, South Dakota, Texas, and Wyoming was awarded to six ESCOs (DukeSolutions, Energy Pacific, ERI Services, Johnson Controls, NORESCO, and Honeywell). 
Each Regional Super ESPC has a contract ceiling of $\$ 750$ million. The remaining two Regional Super ESPCs (Mid-Atlantic and Northeast) will be awarded during FY 1999.

During FY 1998, five Regional Super ESPC delivery orders were awarded. Total project investment is more than $\$ 7$ million, providing significant energy and cost savings to the Government. These delivery orders include two by the Department of Transportation, and one each by the U.S. Department of Agriculture, the Department of Veteran's Affairs, and the General Services Administration. Many more delivery orders are expected to be awarded during FY 1999.

\section{DOE Regional Super ESPC Delivery Orders}

\begin{tabular}{|l|l|l|l|}
\hline \multicolumn{1}{|c|}{ Project Name/Location } & \multicolumn{1}{|c|}{ Project Description } & Project Investment & \multicolumn{1}{c|}{ Savings } \\
\hline $\begin{array}{l}\text { Dept. of Agriculture, U.S. } \\
\text { Forest Service, Forestry } \\
\text { Sciences Laboratory, } \\
\text { Corvallis, Oregon }\end{array}$ & $\begin{array}{l}\text { Lighting retrofit, energy } \\
\text { management and control system, } \\
\text { steam system upgrades, efficient } \\
\text { motors, and fume hood controls }\end{array}$ & $\$ 426,000$ & $\begin{array}{l}\text { Annual savings of } \\
\$ 84,512\end{array}$ \\
\hline $\begin{array}{l}\text { Dept. of Transportation, } \\
\text { Federal Aviation } \\
\text { Administration, Auburn, } \\
\text { Washington }\end{array}$ & $\begin{array}{l}\text { Lighting upgrades and pumping } \\
\text { modifications }\end{array}$ & $\$ 348,682$ & $\begin{array}{l}\text { Annual savings of } \\
\$ 50,271\end{array}$ \\
\hline $\begin{array}{l}\text { Dept. of Transportation, U.S. } \\
\text { Coast Guard, Integrated } \\
\text { Support Command, Kodiak } \\
\text { Island, Alaska }\end{array}$ & $\begin{array}{l}\text { Lighting retrofit, lighting } \\
\text { controls, boiler controls, and } \\
\text { energy management system }\end{array}$ & $\$ 954,353$ & $\begin{array}{l}\text { Annual savings of } \\
\$ 228,824\end{array}$ \\
\hline $\begin{array}{l}\text { Dept. of Veteran's Affairs, } \\
\text { San Francisco Medical } \\
\text { Center, California }\end{array}$ & $\begin{array}{l}\text { Boiler system replacement, } \\
\text { energy management and control } \\
\text { system, medical air compressor } \\
\text { replacement, efficient motors, } \\
\text { and lighting retrofit }\end{array}$ & $\$ 4,763,386$ & $\begin{array}{l}\text { Annual savings of } \\
\$ 528,724\end{array}$ \\
\hline $\begin{array}{l}\text { General Services } \\
\text { Administration, Food and } \\
\text { Drug Administration } \\
\text { Building, Bothell, } \\
\text { Washington }\end{array}$ & $\begin{array}{l}\text { Energy management and control } \\
\text { system, boiler pump upgrades, } \\
\text { variable frequency drives, and } \\
\text { new air compressors and air } \\
\text { dryers }\end{array}$ & $\$ 527,573$ & $\begin{array}{l}\text { Annual savings of } \\
\$ 102,263\end{array}$ \\
\hline
\end{tabular}

Technology-Specific Super ESPCs emphasize a particular advanced energy-efficiency or renewable energy technology to advance these proven yet still emerging technologies in the Federal marketplace. They blanket the entire nation and carry the same agency resource and time saving benefits as Regional Super ESPCs. ESCOs chosen for these awards have unique capabilities and experience in providing energy savings through installation of the technology, thereby greatly reducing the risks of misapplying emerging technologies. Technology-Specific Super ESPCs can also be comprehensive projects employing multiple energy conservation measures, as long as the named technology is the focus of the project.

The first Technology-Specific Super ESPC was awarded to Industrial Solar Technology Corporation in September 1996 to provide solar hot water heating with parabolic troughs. 
Contract value is $\$ 30$ million. During FY 1998, the photovoltaics Technology-Specific Super ESPC was awarded to two ESCOs (CES/Way International and HEC, Inc.). This contract is worth $\$ 50$ million. Over the next several years more Technology-Specific Super ESPCs will be awarded covering a wide range of energy and cost saving technologies. These will include geothermal heat pumps, biomass electric generating systems, and energy-efficient chillers.

A major development for FY 1999 will ease agency access to alternative financing vehicles, including Regional and Technology-Specific Super ESPCs. DOE is establishing a coordinated network of partners under one roof called the FEMP Service Network (FSN). The FSN partnership will include DOE's Office of Energy Efficiency and Renewable Energy, DOE's Golden Field Office, the DOE Regional Offices, National Laboratories, and private sector contractors. The FSN will become a one-stop shop for all the technical and procurement expertise and services agency personnel need to implement successful energy and cost saving projects.

\section{Utility Partnerships}

Although the availability of utility-sponsored demand side management programs is waning, Federal agency reports identified the receipt of at least $\$ 1.5$ million in incentive rebates in FY 1998. Utility incentive activities reported by the agencies occurred at installations widely distributed across the country. This decentralization of utility incentive participation makes it difficult for agencies to track all utility incentive activities undertaken by all respective subagencies, bureaus, and field offices. Total utility incentive benefits received by the Federal Government as a whole for FY 1998 are therefore assumed to be greater than reported.

Under incentive programs, utilities offer rebates to the customer which partially fund and help to promote the installation of new, more efficient equipment such as lighting systems, insulation, cooling equipment, and high efficiency motors. The customer, in this case the Federal Government, is then required to finance the remainder of the equipment cost. Utility incentive programs provide leverage for the user's investment dollars and at the same time help the utility to avoid the cost of building new power plants. EPACT and the Executive Order 12902 place heavy emphasis on utility incentive as a means for Federal agencies to achieve energy conservation.

The following agencies reported participation in demand side management programs in FY 1998:

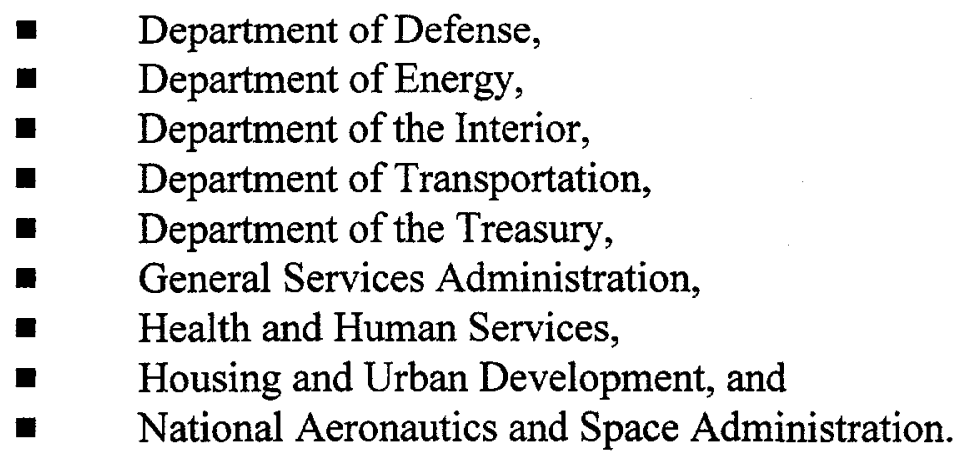




\section{F. Life-Cycle Costing (LCC)}

Section 544 of NECPA, as amended in 1988, requires DOE to establish practical and effective methods for estimating and comparing the life-cycle costs for Federal buildings using the sum of all capital and operating costs for energy systems of new buildings involved over the expected life of such systems or during a period of 25 years, whichever is shorter, and using average fuel costs and a discount rate determined by the Secretary of Energy. In addition, section 544 requires that procedures be developed in applying and implementing the methods that are established. EPACT further amends NECPA to require, after January 1, 1994, agencies which lease buildings to fully consider the efficiency of all potential building space at the time of renewing or entering into a new lease.

On November 20, 1990, DOE issued a Notice of Final Rulemaking to amend Title 10 of the Code of Federal Regulations, Part 436, which sets forth guidelines applicable to Federal agency inhouse energy management programs. The principal regulatory changes involved amending the life-cycle cost methodology and procedures to provide for an annually determined, market-based discount rate and for a more effective system to revise annually the energy cost escalation rates that Federal agencies are required to assume. In developing the final amendments, the Department of Energy actively consulted with the Office of Management and Budget, the Department of Defense, and the General Services Administration.

In the past, DOE's Federal Energy Management Program has published updated fuel price projections for life-cycle cost analyses on October 1 of each year to coincide with the beginning of the fiscal year. The FY 1998 update of the Energy Price Indices and Discount Factors for LifeCycle Cost Analysis, Annual Supplement to Handbook 135 was published and distributed to Federal energy managers in April 1997.

\section{G. Procurement Policy}

The Federal Government is the single largest purchaser of energy-related products and the largest user of energy in the U.S. Each year, the Federal Government purchases an estimated $\$ 10$ to $\$ 20$ billion in energy-related products. There is enormous potential for energy and dollar savings through procurement policies emphasizing energy efficiency. Such policies will not only reduce emission of greenhouse gases, but will expand the market for energy efficient products, create a strong "market pull" for new technologies, and set a clear example for state and local governments and private industry.

Executive Order 12902, "Energy Efficiency and Water Conservation at Federal Facilities," in conjunction with EPACT, established a clear mandate for agencies to use life-cycle cost analysis in their purchasing of energy-consuming equipment and to purchase "best practice" products whenever practicable and whenever they meet the agency's specific performance requirements and are cost-effective. Best practice products are those which are in the upper 25 percent of energy efficiency for all similar products, or products that are at least 10 percent more efficient than the minimum level that meets Federal standards. 
Real or perceived barriers to energy-efficient purchasing also arise at the policy level. To ameliorate this situation, a Federal Acquisition Circular (FAC) - the medium for Federal Acquisition Regulation (FAR) amendments-was issued on August 22, 1997. The new regulation includes language on the acquisition of environmentally preferable and energy-efficient products and services, defining "energy-efficient" in accordance with Executive Order 12902. The relevant section from 48 CFR, Part 23.704 states:

(a) Agencies shall implement cost-effective contracting preference programs favoring the acquisition of environmentally preferable and energy-efficient products and services.

(b) The following environmental objectives shall be addressed through the acquisition process:

(1) Obtaining products and services considered to be environmentally preferable (based on EPA-issued guidance).

(2) Obtaining products considered to be energy-efficient; i.e., products that are in the upper 25 percent of energy-efficiency for all similar products or products that are at least 10 percent more efficient than the minimum level that meets Federal standards (see E.O. 12902, Section 507).

DOE has also developed policy guidance for its own purchasing officers and program staff, including a section on energy-efficient purchasing in the DOE Acquisition Guide.

In FY 1998, DOE published a feasibility study that was produced in response to Section 152 of EPACT directing the Secretary of Energy to conduct a study to evaluate the potential use of the purchasing power of the Government to promote the development and commercialization of energy-efficient products. The study has two major parts: the first covers the process used in buying new products, the models in use, and how to do a new technology procurement, while the second part covers product selection, including a discussion of product characteristics with merit.

To assist Federal agencies in meeting the requirements of EPACT and E.O. 12902, the DOE Office of Federal Energy Management Program (FEMP), in cooperation with the Council on Environmental Quality and OMB's Office of Federal Procurement Policy, sponsored the Federal Procurement Challenge in September 1995. The heads of 22 Government agencies, representing almost 95 percent of the total Federal buying power, signed the Procurement Challenge committing themselves to purchasing energy- and water-saving products that will reduce their operating costs.

DOE FEMP provides Procurement Challenge participants with decision tools and technical support to help them achieve the Challenge goals. In 1998, FEMP produced and distributed seven additional product energy efficiency recommendations to be added to the one-stop shopping guide, Buying Energy Efficient Products, to help Federal purchasers identify products which meet the energy efficiency requirements of E.O. 12902.

The guide, which is also available on FEMP's Internet Web site at www.eren.doe.gov/femp/procurement, now includes 29 product energy efficiency 
recommendations. The guide also covers streamlined procurement, including a discussion of the Basic Ordering Agreement for CFC-free chillers and will ultimately contain recommendations for 60 products. Categories covered range from fluorescent lighting to office equipment to commercial chillers. These recommendations will help agencies meet the goals of the Procurement Challenge by clearly defining the top 25 percent of efficiency for each product category, as well as illustrating the dollar savings that purchasers will realize from choosing products that meet the recommended levels instead of less efficient models. In addition, these recommendations are given in conjunction with EPA's ENERGY STAR $®$ Program, which labels those products that meet or exceed the energy efficiency criteria for government purchasing.

To be most effective, the product efficiency recommendations must reach Federal buyers in a form they can use and be closely linked with other purchasing guidance, such as technical specifications and agency-specific policies and practices. Pursuant to this concern, FEMP has made considerable progress in partnership with the two major Government supply agencies, the General Services Administration and the Defense Logistics Agency. FEMP is working with GSA's Tools and Appliance Center in Fort Worth and with the Defense Logistics Agency (DLA) to identify energy efficient appliances in their supply system and code them with the energy efficient symbol ${ }_{\mathrm{E}}^{\mathrm{E}}$. Four appliances have been labeled so far. Cooperative efforts with GSA and DLA will extend use of the ${ }_{E}{ }_{E}$ symbol to other products in the Federal supply system, including on-line databases for electronic commerce. As a result of FEMP's coding efforts, customers shopping on-line can query for performance information.

Both DOD and GSA use the Federal Logistics Information System (FLIS) to procure products and equipment. FLIS catalogs millions of items by National Stock Numbers which can be accessed by vendor name or code. Currently the FAR requires only information on price, performance, and delivery schedule. DLA is trying to establish environmental segments and attributes within FLIS. DOD's Joint Logistics Commanders (JLC) support this initiative and have established the JLC Environmental Steering Committee. The Steering Committee will spearhead the development of an acquisition process to collect and rank information on environmental preferences, including energy efficiency, hazardous or toxic materials in the item or packaging, percent of recycled content, and biodegradability.

FEMP is working to expand the line of products available through Single Order Purchasing. The biggest success has been the chiller Basic Ordering Agreement (BOA). This innovative initiative was developed by the DOE Office of Defense Programs, FEMP, and the General Services Administration to streamline the procurement of large, energy-efficient, CFC-free replacement chillers. Effective on November 15, 1996, the BOA allows Federal agencies to purchase chillers through the GSA Schedule by adopting a series of general specifications while permitting other important features to be individually specified. Five manufacturers have met the DOE general specifications and any chiller bought under this agreement complies with Executive Order 12902. The DOE Rocky Flats facility was the first site to use the BOA. The streamlined procurement takes 45 to 60 days, allowing customers to avoid the cumbersome bidding process previously required for chiller purchases. Cumulative energy cost savings are estimated at $\$ 1.4$ billion over the 20-year life of replacement chillers to be installed in Federal facilities. Agencies will also realize an estimated $\$ 600$ million in administrative cost savings and associated operation/ 
maintenance services. This BOA will help "pull" the entire chiller market toward greater efficiency.

Coordination efforts with other buyer groups, utilities, and "market-pull" programs give FEMP's Procurement Challenge even greater leverage in meeting its energy saving, cost saving, and pollution prevention objectives. To help educate and inform government buyers at the State, local, and Federal levels on energy-efficient purchasing practices, DOE and EPA began the Energy Efficient Procurement Collaborative and the ENERGY STAR $®$ Procurement Challenge. Its mission is to help educate and inform government buyers at the State, local, and Federal levels on energy-efficient purchasing practices, including on-line access to databases on efficient products and coordination of efficiency criteria and model specifications among public agencies. An important part of the strategy is to gain support at the top from such groups as the National Governors' Association and National Association of Counties.

Other FEMP outreach activities include the "You Have the Power" campaign to increase awareness of energy efficient procurement among Federal personnel. The Alliance to Save Energy, a non-profit, bipartisan group promoting energy efficiency currently chaired by Senator Jeff Bingaman, is developing a program with industry to promote the use of the energy efficient symbol, E E.

The Energy Efficiency Procurement Working Group convened three interagency roundtable discussions on November 4, 5, and 6, 1997, to obtain feedback on Federal procurement issues. The roundtables were intended to improve the Working Group's and FEMP's understanding of the Federal procurement process, to obtain feedback on existing program activities and information, to conduct market research to obtain a better perspective on the procurement process, and to solicit ideas on how to increase the program's effectiveness. The Working Group reached several conclusions from the roundtable discussions, including that agency personnel need to be trained and educated about mandates and Executive Orders with an emphasis on "how to", there needs to be an emphasis on educating the general public on energy efficiency, and that linking water use to energy savings would be effective in reducing energy use.

In addition, the Energy Efficient Procurement Working Group held subsequent meetings in December of 1997 and 1998 to discuss the conclusions reached by the roundtables and to obtain feedback on program activities. 


\section{H. Public Education Programs}

NECPA, 42 U.S.C. $\S 8258$ (b), requires the Secretary of Energy to include in this and subsequent annual reports information on public education programs carried out by Federal agencies and previously reported under the authority of section 381 of the Energy Policy and Conservation Act (EPCA), 42 U.S.C. $\S 6361(b)$.

EPCA requires the Secretary of Energy to establish and carry out public education programs to encourage energy conservation and energy efficiency and to promote vanpooling and carpooling arrangements. The Department of Transportation (DOT) has promoted ride sharing activities, while DOE has been responsible for other energy conservation education programs.

Through its Federal Highway Administration, DOT obligates Federal aid funds to assist State and local agencies in implementing programs designed to encourage the use of car pools, van pools, and buses by commuters. DOT efforts have included van pool acquisition programs, fringe and corridor parking facilities, ride-matching projects, preferential treatments for high occupancy vehicles, and transit service improvement. Since 1974, more than $\$ 875$ million in Federal aid highway funds have been spent on such projects in an effort to establish self-sufficient programs across the Nation.

The Department of Transportation's Technology Sharing Program (TSP) makes high quality reports in a user-friendly format available to the non-scientist or technical person to understand and act on transportation problems of state and local governments. This low-cost program disseminates technical reports on a variety of topics to this user community, thus saving them the time and cost of researching the information on an individual basis, or not having the information at all. The TSP products consist of reports, manuals, and summary documents which can be ordered at the following Internet site: http://www.tsp.dot.gov/cgi-bin/borwsere.pl

Recent emphasis areas have included commuter issues and travel demand, traffic congestion, land-use development, and risk assessment. In addition, a variety of products of the National Science and Technology Council's Subcommittee on Transportation R\&D are also available through the site.

The Department of Energy's public education programs encompass a wide variety of services, objectives, and audiences, covering all major areas of conservation and renewable energy. DOE has organized its technology transfer programs to meet the specific information requirements of various audiences.

Three services are managed through subcontracts at the National Renewable Energy Laboratory (NREL): DOE's Energy Efficiency and Renewable Energy Clearinghouse (EREC), DOE's Energy Efficiency and Renewable Energy Network (EREN), and the FEMP Help Desk.

EREC provides basic, technical, and financial information on various energy efficiency/renewable energy technologies and programs. The audience served by EREC includes the general public, business and industry, educational community, media, utility companies, and state and local governments. Information is provided in the form of fact sheets, DOE and National Laboratory 
books and brochures, bibliographies, and on-line computer-generated technology synopses. Some requests are handled completely over the phone and the caller receives no publications. EREC's telephone number is 800-DOE-EREC and its Web site is at www.eren.doe.gov/consumerinfo. In FY 1998, EREC staff responded to 83,915 inquiries and disseminated 295,317 publications.

EREN is the official Web site of the U.S. Department of Energy's Office of Energy Efficiency and Renewable Energy (EERE). The audience served by EREN includes business and industry, the general public, the educational community, the media, and state and local governments. EREN's Web address is www.eren.doe.gov. In 1998, EREN averaged 70,000 unique users per month, and 2.8 million hits per month. The site is a comprehensive resource for energy information, providing links to more than 600 energy-related Web sites, allowing keyword searches, and offering a full range of information on topics such as building energy efficiency, wind power, and alternative fuels. In addition, EERE provides its organizational chart, major initiatives, and budget. The site also features current press releases, consumer information, and lists of discussion groups on various energy-related topics. There are even forms to submit energy-related questions and to subscribe to the EREN Network News e-mail newsletter.

The Office of Federal Energy Management Programs (FEMP) Help Desk provides Federal energy managers with specialized information on effective energy management practices, technical assistance on implementing Federal sector energy projects, financing information, energy modeling software, publications, and energy management training programs. The primary goal of this service is to assist Federal agencies in meeting various legislative requirements. The Help Desk responds to requests for information via a toll-free telephone service, electronic mail, and through the Internet. The Help Desk was merged into EREC in FY 1997. The telephone number is 800-DOE-3732. The Web site is www.eren.doe.gov/femp.

The National Energy Information Center (NEIC) responds to public and private sector questions on energy production, consumption, prices, resource availability, and projections of supply and demand. It also makes available the publications produced by the DOE Energy Information Administration. NEIC provides information to Federal employees and the public at www.eia.doe.gov. Electronic inquiries may be sent to infoctr@eia.doe.gov. In 1998, NEIC staff responded to 23,272 inquiries and distributed approximately 36,756 publications.

The Office of Scientific and Technical Information (OSTI), as part of the Office of Science, provides coordination and direction for the management of scientific and technical information resulting from the DOE's multi-billion dollar research and development activities. As a crosscutting Headquarters office, OSTI accomplishes its mission through the Scientific and Technical Information Program (STIP). STIP operates in partnership with program offices, operations offices, and contractors to develop and implement information management "best business practices" to ensure that DOE maximizes the return on its $\$ 6$ billion annual R\&D investment.

In support of national competitiveness, OSTI collects, processes, and disseminates DOEoriginated research information and selected worldwide research literature on subjects of interest to domestic communities. OSTI also provides scientific and technical information services to, or on behalf of, DOE elements in support of Departmental mandates, missions, and objectives. OSTI serves the public directly or indirectly through agreements with the National Technical 
Information Service, Government Printing Office, depository libraries, and commercial vendors. In 1998 OSTI unveiled EnergyFiles, a publicly available, web-based gateway to a wide array of energy-related information. Included among the EnergyFiles family is the DOE Information Bridge, an electronic full-text collection of 26,000 documents available to the DOE research community. DOE Information Bridge was made publicly available during 1998.

OSTI manages a comprehensive collection of approximately one million scientific and technical information documents, representing 50 years of energy-related activities. The organization also maintains the Energy Science and Technology Database (EDB), which has more than 3.5 million summaries of DOE and worldwide information. EDB is made available to the public on-line and on CD-ROM through commercial vendors. The majority of its users are industry, Federal and State officials, contractors, libraries, research institutions, and the public. In FY 1998, OSTI added more than 200,000 research summaries to the database and provided 22,000 full-text documents for public availability to the National Technical Information Service and the Government Printing Office Depository Library Program.

FY 1998 initiatives included a strategic effort to process and disseminate information in an increasingly decentralized environment. As a continuing step towards a "National Library of Energy Science and Technology," the effort will significantly improve DOE and public access to bibliographic and full-text information without major additional investment. In addition to the core program activities, OSTI's other services include developing Internet-based applications for DOE offices, providing information management advice and consultation to the Departmental community, managing and disseminating DOE and Nuclear Regulatory Commission scientific and technical software, and representing the United States in multilateral and bilateral international information exchange agreements.

The DOE public information mechanisms include several direct service programs designed to provide technical assistance to specific target groups. Some of these include:

- The State Energy Program, a formula grant program, which provides a flexible, supportive framework to enable the States to address their own energy priorities, as well as focus on national initiatives and strengthens their capabilities to deliver energy services. This customerdriven program seeks to increase the extent to which Federal, State, and local governments work with other public and private sector entities to achieve widespread adoption of available energy efficiency and renewable energy technologies, and to demonstrate the use of emerging technologies which benefit the entire economy. This also includes working with the building industry and consumers for improvements in residential energy efficiency.

- The Special Projects component of the State Energy Program offers States the opportunity to apply for competitively selected grants covering a wide range of activities that may expand upon a State's formula grant activities or offer an opportunity to take new initiatives. These projects are designed to utilize the State's unique and effective skills in forming and sustaining partnerships with local governments, industry, utilities, and private organizations to remove barriers and implement programs using DOE's Office of Energy Efficiency and Renewable Energy's targeted technologies, thereby providing DOE a direct way to accomplish the Department's technology deployment goals. Many of these projects involve the 
dissemination of information about, and/or the demonstration or the viability of a variety of energy efficiency and renewable energy applications.

- The Industrial Assessment Center Program (IAC) provides no-charge energy, waste, and productivity assessments to help small and mid-sized manufacturers identify measures to maximize energy-efficiency, reduce waste, and improve productivity. The analyses are performed by local teams of engineering faculty and students from 30 participating universities across the country.

A full list of DOE's energy education, extension, and information services is provided in Appendix E to this report. 


\section{ENERGY MANAGEMENT IN BULLDINGS AND FACILITIES}

\section{A. Energy Consumption and Costs for Buildings and Facilities}

The Federal Government provides energy to approximately 500,000 buildings and facilities comprising approximately 3.1 billion square feet of floor area. This energy is used to provide lighting, heating, ventilation, air conditioning, and other standard building services, as well as a significant amount of process operations that are not reported separately. ${ }^{11}$ Federal buildings include both Federally-owned and leased buildings. However, in many instances the lessor pays the energy bill, and consumption and cost data may not be available to the Government.

Accordingly, Federal agencies report data for leased space to the maximum extent practicable. ${ }^{12}$

Table 4-A shows the total primary energy consumed in Federal buildings and facilities, including energy resources used to generate, process, and transport electricity and steam. ${ }^{13}$ Primary energy consumed in buildings and facilities in FY 1998 decreased 12.8 percent from FY 1985 and increased 1.5 percent from FY 1997.

Table 4-B shows that agencies have decreased net energy consumption in buildings by 25.8 percent, from 471.0 trillion Btu in FY 1985 to 349.4 trillion Btu in FY 1998. A comparison to FY 1997 shows a decrease of 0.1 percent in total buildings energy consumption.

FIGURE 5

Defense and Civilian Energy Consumption in

Of the 28 agencies represented on the Buildings and Facilities by Fuel Type, FY 1998 tables for FY 1998, 11, including DOD, consume more than 98 percent of the reported buildings energy use. Energy used in buildings accounts for approximately 33.5 percent of the total 1.04 quads used by the Federal Government. The mix of Federal buildings energy use for Defense and civilian agencies is depicted in Figure 5. Electricity constitutes 42.9 percent (150.0 trillion Btu) of Federal buildings energy use; 35.3 percent is accounted for by natural gas

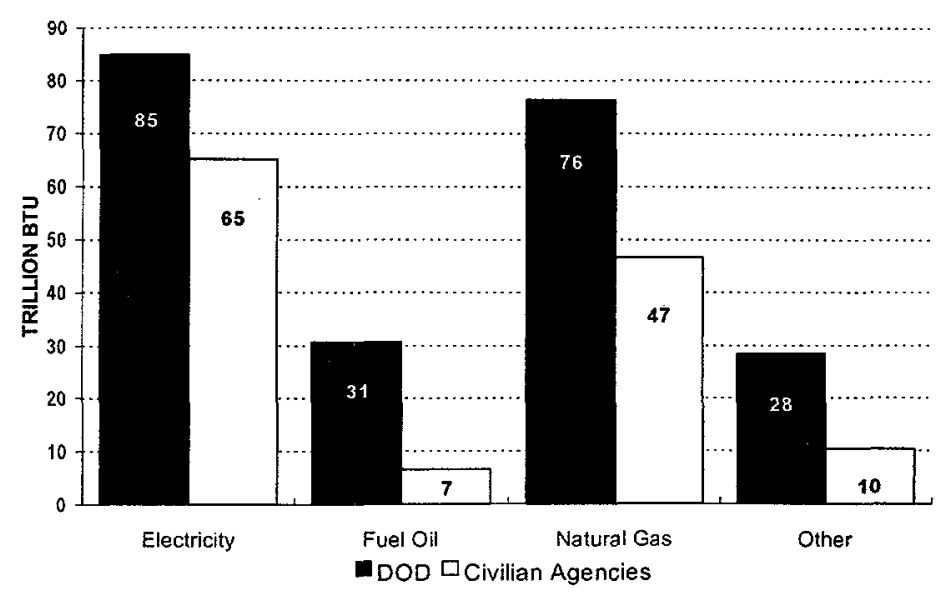

\footnotetext{
${ }^{11}$ Process energy is that energy used in buildings for operations other than standard building services. In cases where separate reporting was not possible, due to the lack of meters or estimation techniques, process energy was reported as though it was part of the energy used for standard building services.

${ }^{12}$ The General Services Administration (GSA) is the primary leasing agent for the Federal Government, although most of the other agencies do have some leasing authority. In some cases, GSA will delegate operations and maintenance responsibility to individual agencies for leased space, requiring the agency to be responsible for paying the utility bills and reporting energy consumption.
}

${ }^{13}$ Source conversion factors of 11,600 Btu per kilowatt hour for electricity and 1,390 Btu per pound of steam are used to calculate primary energy consumption. See Appendix B for conversion factors for net energy consumption. 
TABLE 4-A

FEDERAL PRIMARY ENERGY CONSUMPTION IN BUILDINGS AND FACILITIES

(In Billions of Btu, with Conversions to Millions of Barrels of Oil Equivalent [MBOE], and Petajoules [Joule x 10 ${ }^{15}$ ])

\begin{tabular}{|c|c|c|c|c|c|c|c|c|c|c|c|c|}
\hline $\begin{array}{l}\text { CIVILIAN } \\
\text { AGENCY }\end{array}$ & $\begin{array}{l}\text { FY } \\
1985\end{array}$ & $\begin{array}{l}\text { FY } \\
1990\end{array}$ & $\begin{array}{l}\text { FY } \\
1991\end{array}$ & $\begin{array}{l}\text { FY } \\
1992\end{array}$ & $\begin{array}{c}\text { FY } \\
1993\end{array}$ & $\begin{array}{c}\text { FY } \\
1994\end{array}$ & $\begin{array}{c}F Y \\
1995\end{array}$ & $\begin{array}{c}F Y \\
1996\end{array}$ & $\begin{array}{c}\text { FY } \\
1997\end{array}$ & $\begin{array}{c}\text { FY } \\
1998\end{array}$ & $\begin{array}{c}\text { \%CHANGE } \\
85-98\end{array}$ & $\begin{array}{c}\% \text { CHANGE } \\
97-98\end{array}$ \\
\hline USPS & $39,441.0$ & $46,961.6$ & $48,347.0$ & $50,147.1$ & $54,073.7$ & $55,445.6$ & $56,551.3$ & $58,757,3$ & $53,728.0$ & $56,049.9$ & 42.1 & 4.3 \\
\hline DOE & $57,430.1$ & $54,839.0$ & $52,941.5$ & $56,282.4$ & $57,050.7$ & $55,100.0$ & $53,654,4$ & $53,930.0$ & $50,225.1$ & $48,980.3$ & -14.7 & -2.5 \\
\hline VA & $42,333.7$ & $43,818.9$ & $44,954.2$ & $44,759.7$ & $45,620,4$ & $46,265.4$ & $46,823.0$ & $48,062.3$ & $48,419.3$ & $48,899.3$ & 15.5 & 1.0 \\
\hline GSA & $41,207.0$ & $35,985.0$ & $34,685.4$ & $34,300.3$ & $34,198.2$ & $33,661.4$ & $32,912.4$ & $34,286.0$ & $34,492.7$ & $34,469.9$ & -16.3 & -0.1 \\
\hline$S T^{1}$ & 689.2 & 817.3 & 845.4 & 829.4 & 133.4 & 235.6 & 255.3 & 780.5 & 968.1 & $18,863.1$ & $2,637.0$ & $1,848.5$ \\
\hline DOJ & $8,962.7$ & $9,376.1$ & $12,038.8$ & $9,285.9$ & $11,999.4$ & $11,390.0$ & $11,836.6$ & $14,391.8$ & $14,681.7$ & $15,263.0$ & 70.3 & 4.0 \\
\hline HHS & $10,458.1$ & $16,191.3$ & $14,353.7$ & $15,857.0$ & $16,086.8$ & $16,320.7$ & $11,904.8$ & $12,623.5$ & $14,320.3$ & $13,966.9$ & 33.6 & -2.5 \\
\hline NASA & $6,810.9$ & $8,021.3$ & $8,206.4$ & $7,946.3$ & $8,007.7$ & $8,115.1$ & $8,670.7$ & $9,491.2$ & $9,990.5$ & $10,066.4$ & 47.8 & 0.8 \\
\hline DOT & $8,298.7$ & $7,114.8$ & $6,609.9$ & $8,355.1$ & $8,687.6$ & $8,427.4$ & $9,020.4$ & $9,097.4$ & $9,378.3$ & $8,547.1$ & 3.0 & -8.9 \\
\hline DOI & $8,432.5$ & $7,511.8$ & $7,746.9$ & $6,824.4$ & $8,320.8$ & $8,186.2$ & $7,646.7$ & $6,177.5$ & $7,203.8$ & $7,422.2$ & -12.0 & 3.0 \\
\hline USDA & $4,347.2$ & $5,397.9$ & $5,604.9$ & $5,339.6$ & $5,477.6$ & $5,253.7$ & $5,118.6$ & $5,280.2$ & $4,701.3$ & $4,969.0$ & 14.3 & 5.7 \\
\hline TRSY & $1,451.0$ & $5,004.1$ & $4,372.2$ & $4,805.4$ & $4,250.4$ & $4,351.0$ & $3,752.5$ & $3,607.0$ & $4,802.7$ & $4,553.5$ & 213.8 & -5.2 \\
\hline DOL & $3,687.8$ & $3,864.3$ & $3,784.8$ & $3,821.2$ & $3,955.1$ & $4,033.6$ & $3,922.1$ & $4,043.4$ & $4,079.0$ & $4,109.4$ & 11.4 & 0.7 \\
\hline TVA & $1,321.0$ & $1,410.5$ & $1,423.4$ & $1,422.0$ & $1,465.1$ & $2,228.3$ & $2,465.3$ & $2,387.9$ & $2,250.3$ & $2,220.2$ & 68.1 & -1.3 \\
\hline EPA & $1,618.3$ & $1,616.4$ & $1,782.6$ & $1,811.6$ & $1,898.2$ & $1,984.3$ & $2,131.8$ & $2,096.3$ & $2,075.0$ & $2,083.4$ & 28.7 & 0.4 \\
\hline DOC & $1,189.1$ & $3,227.4$ & $3,220.7$ & $1,483.1$ & $1,664.7$ & $2,047.3$ & $1,361.7$ & $1,313.7$ & $1,303.3$ & $1,207.8$ & 1.6 & -7.3 \\
\hline HUD & 349.3 & 426.5 & 417.0 & 384.1 & 348.6 & 323.7 & 316.1 & 332.9 & 320.6 & 310.4 & -11.1 & -3.2 \\
\hline FCC & 29.5 & 41.0 & 43.7 & 33.9 & 35.1 & 39.4 & 39.4 & 31.7 & 31.7 & 31.7 & 7.2 & 0.0 \\
\hline PCC & 90.5 & 97.2 & 110.2 & 102.3 & 110.5 & 106.8 & 108.6 & 110.3 & 115.3 & 0.0 & -100.0 & -100.0 \\
\hline OTHER* & 947.5 & $1,747.8$ & $1,281.1$ & $1,273.7$ & $1,035.2$ & $1,023.3$ & $3,054.3$ & $5,026.6$ & $5,292.9$ & $5,045.0$ & 432.5 & -4.7 \\
\hline \multicolumn{13}{|c|}{ CIVILIAN AGENCIES } \\
\hline TOTAL & $239,095.2$ & $253,470.1$ & $252,769.9$ & $255,064.4$ & $264,419.4$ & $264,538.7$ & $261,546.1$ & $271,827.5$ & $268,380.0$ & $287,058.3$ & 20.1 & 7.0 \\
\hline DOD & $581,170.2$ & $580,184.6$ & $523,370.8$ & $524,164.8$ & $523,295.3$ & $502,215.0$ & $476,188.2$ & $452,388.4$ & $436,940.7$ & $428,492.1$ & -26.3 & -1.9 \\
\hline \multicolumn{13}{|c|}{ ALL AGENCIES } \\
\hline TOTAL & $820,265.5$ & $833,654.7$ & $776,140.7$ & $779,229.2$ & $787,714.6$ & $766,753.7$ & $737,734.3$ & $724,216.0$ & $705,320.7$ & $715,550.4$ & -12.8 & 1.5 \\
\hline MBOE & 140.8 & 143.1 & 133.2 & 133.8 & 135.2 & 131.6 & 126.6 & 124.3 & 121.1 & 122.8 & & \\
\hline Petajoules & 865.4 & 879.5 & 818.8 & 822.1 & 831.0 & 808.9 & 778.3 & 764.0 & 744.1 & 754.9 & & \\
\hline
\end{tabular}

DATA AS OF $01 / 10 / 00$

*Other includes for certain years the CFTC, CIA, EEOC, FEMA, FTC, NARA, NSF, NRC, OPM, RRB, SSA, USIA, and FERC.

Note: This table uses a conversion factor for electricity of 11,600 Btu per kilowatt hour and 1,390 Btu per pound of steam. Agencies are listed in descending order of consumption for the current year. Sum of components may not equal total due to independent rounding.

${ }^{1}$ In 1998, the State Department developed a statistical method for estimating the energy consumption of its foreign buildings worldwide and included the estimate in their 1998 data. Foreign building consumption has not been reported in full in previous years.

Source: Federal Agency Annual Energy Management Data Reports 
TABLE 4-B

FEDERAL NET ENERGY CONSUMPTION IN BUILDINGS AND FACILITIES

(In Billions of Btu, with Conversions to Millions of Barrels of Oil Equivalent [MBOE], and Petajoules [Joule $\mathrm{x} 10^{15}$ ])

\begin{tabular}{|c|c|c|c|c|c|c|c|c|c|c|c|c|}
\hline $\begin{array}{l}\text { CIVILIAN } \\
\text { AGENCY }\end{array}$ & $\begin{array}{c}\text { FY } \\
1985\end{array}$ & $\begin{array}{c}F Y \\
1990\end{array}$ & $\begin{array}{c}F Y \\
1991\end{array}$ & $\begin{array}{l}\text { FY } \\
1992\end{array}$ & $\begin{array}{c}\text { FY } \\
1993\end{array}$ & $\begin{array}{c}\text { FY } \\
1994\end{array}$ & $\begin{array}{c}\text { FY } \\
1995\end{array}$ & $\begin{array}{c}F Y \\
1996\end{array}$ & $\begin{array}{c}\text { FY } \\
1997\end{array}$ & $\begin{array}{c}\text { FY } \\
1998\end{array}$ & $\begin{array}{c}\text { \%CHANGE } \\
85-98\end{array}$ & $\begin{array}{c}\% \text { CHANGE } \\
97-98\end{array}$ \\
\hline VA & $24,552.0$ & $24,380.1$ & $24,733.0$ & $24,620.0$ & $25,077.2$ & $25,213.4$ & $25,075.4$ & $26,172.3$ & $26,062.0$ & $26,216.9$ & 6.8 & 0.6 \\
\hline DOE & $32,923.2$ & $29,297.3$ & $28,077.6$ & $29,564.3$ & $30,546.8$ & $29,193.0$ & $28,011.6$ & $25,987.3$ & $23,746.2$ & $23,126.7$ & -29.8 & -2.6 \\
\hline USPS & $16,238.3$ & $18,480.0$ & $18,620.8$ & $19,449.2$ & $21,159.8$ & $21,602.2$ & $21,649.7$ & $22,210.0$ & $22,006.4$ & $22,683.9$ & 39.7 & 3.1 \\
\hline GSA & $16,563.0$ & $13,937.3$ & $13,116.3$ & $13,061.4$ & $13,075.2$ & $12,832.9$ & $12,366.7$ & $13,439.4$ & $13,353.7$ & $13,123.7$ & -20.8 & -1.7 \\
\hline DOJ & $6,112.0$ & $4,863.8$ & $5,894.3$ & $3,869.2$ & $6,245.8$ & $6,143.9$ & $6,303.9$ & $7,490.6$ & $8,003.7$ & $7,783.0$ & 27.3 & -2.8 \\
\hline$S T^{1}$ & 232.1 & $\begin{array}{r}4,000.0 \\
267.7\end{array}$ & $\begin{array}{r}274.2 \\
274.2\end{array}$ & $\begin{array}{r}r, 000.2 \\
273.8\end{array}$ & $\begin{array}{r}0,24.0 \\
45.3\end{array}$ & $\begin{array}{r}0.9 \\
82.9\end{array}$ & $\begin{array}{r}0,900 \\
92.9\end{array}$ & 289.2 & $\begin{array}{r}0,000.1 \\
337.5\end{array}$ & $7,422.7$ & $3,098.1$ & $2,099.3$ \\
\hline HHS & $5,837.3$ & $7,957.0$ & $7,107.1$ & $7,954.7$ & $7,969.1$ & $8,231.9$ & $6,024.2$ & $6,610.3$ & $7,417.8$ & $6,953.1$ & 19.1 & -6.3 \\
\hline NASA & $3,095.7$ & $3,450.1$ & $3,375.6$ & $3,335.8$ & $3,250.4$ & $3,262.6$ & $3,466.3$ & $3,730.4$ & $3,875.4$ & $3,941.4$ & 27.3 & 1.7 \\
\hline DOI & $4,762.4$ & $4,039.4$ & $3,886.2$ & $3,173.4$ & $3,974.3$ & $3,922.1$ & $3,596.3$ & $2,979.1$ & $3,668.5$ & $3,747.4$ & -21.3 & 2.2 \\
\hline DOT & $4,500.3$ & $3,750.4$ & $3,297,6$ & $3,918.0$ & $3,886.6$ & $3,903.0$ & $3,856.9$ & $3,952.2$ & $3,800.1$ & $3,667.9$ & -18.5 & -3.5 \\
\hline $\mathrm{DOL}$ & $2,153.0$ & $2,137.1$ & $2,044.1$ & $2,063.7$ & $2,145.8$ & $2,158.3$ & $2,028.8$ & $2,153.9$ & $2,153.9$ & $2,190.2$ & 1.7 & 1.7 \\
\hline USDA & $2,096.3$ & $2,363.0$ & $2,342.4$ & $2,151.6$ & $2,234.8$ & $2,164.5$ & $2,083.1$ & $2,261.3$ & $1,996.0$ & $2,111.1$ & 0.7 & 5.8 \\
\hline TRSY & 615.0 & $1,918.4$ & $1,494.7$ & $1,749.1$ & $1,568.0$ & $1,624.7$ & $1,418.3$ & $1,484.9$ & $1,904.4$ & $1,741.2$ & 183.1 & -8.6 \\
\hline EPA & 772.3 & 747.0 & 822.4 & 839.7 & 894.1 & 943.4 & $1,021.1$ & $1,023.3$ & $1,011.5$ & $1,022.9$ & 32.4 & 1.1 \\
\hline TVA & 402.4 & 427.8 & 426.6 & 425.6 & 439.8 & 664.0 & 748.5 & 728.4 & 665.6 & 658.4 & 63.6 & -1.1 \\
\hline DOC & 540.3 & $1,376.0$ & $1,406.9$ & 531.0 & 571.9 & 752.9 & 494.9 & 490.1 & 457.2 & 429.9 & -20.4 & -6.0 \\
\hline HUD & 116.9 & 140.3 & 132.2 & 123.1 & 116.2 & $\uparrow 13.5$ & 105.9 & 115.4 & 109.3 & 103.1 & -11.8 & -5.7 \\
\hline FCC & 11.2 & 14.8 & 14.9 & 12.4 & 12.9 & 14.1 & 14.1 & 12.8 & 12.8 & 12.8 & 14.4 & 0.0 \\
\hline PCC & 26.6 & 28.6 & 32.4 & 30.1 & 32.5 & 31.4 & 31.9 & 32.4 & 33.9 & 0.0 & -100.0 & -100.0 \\
\hline OTHER* & 369.0 & 698.5 & 503.8 & 518.3 & 426.0 & 403.9 & $1,189.7$ & $1,884.6$ & 1,989.1 & $1,898.7$ & 414.5 & -4.5 \\
\hline \multicolumn{13}{|c|}{ CIVILIAN AGENCIES } \\
\hline TOTAL & $121,919.5$ & $120,274.5$ & $117,603.1$ & $117,664.1$ & $123,672.5$ & $123,258.6$ & $119,580.1$ & $123,047.9$ & $122,605.0$ & $128,834.8$ & 5.7 & 5.1 \\
\hline DOD & $349,076.7$ & $321,101.6$ & $286,885.7$ & $295,719.8$ & $279,726.5$ & $262,661.5$ & $247,166.9$ & $235,688.1$ & $227,070.0$ & $220,567.6$ & -36.8 & -2.9 \\
\hline \multicolumn{13}{|c|}{ ALL AGENCIES } \\
\hline TOTAL & $470,996.2$ & $441,376.1$ & $404,488.9$ & $413,383.9$ & $403,399.0$ & $385,920.2$ & $366,747.0$ & $358,736.0$ & $349,675.0$ & $349,402.4$ & -25.8 & -0.1 \\
\hline MBOE & 80.9 & 75.8 & 69.4 & 71.0 & 69.3 & $\quad 66.3$ & 63.0 & 61.6 & 60.0 & $\begin{array}{r}07+90.4 \\
60.0\end{array}$ & & \\
\hline Petajoules & 496.9 & 465.6 & 426.7 & 436.1 & 425.6 & 407.1 & 386.9 & 378.5 & 368.9 & 368.6 & & \\
\hline
\end{tabular}

*Other includes for certain years the CFTC, CIA, EEOC, FEMA, FTC, NARA, NSF, NRC, OPM, RRB, SSA, USIA, and FERC.

Note: This table uses a conversion factor for electricity of 3,412 Btu per kilowatt hour. Agencies are listed in descending order of consumption for the current year.

Sum of components may not equal total due to independent rounding.

In 1998, the State Department developed a statistical method for estimating the energy consumption of its foreign buildings worldwide and included the estimate in their 1998 data. Foreign building consumption has not been reported in full in previous years.

Source: Federal Agency Annual Energy Management Data Reports 
(123.2 trillion Btu), and 10.7 percent by fuel oil (37.3 trillion Btu). Coal, purchased steam, liquefied petroleum gas (LPG)/propane, and energy reported as "other" (comprised mainly of chilled water and renewable energy), account for the remaining 11.1 percent.

Figure 6 illustrates the proportion of energy consumption in buildings and facilities that is attributable to electricity for FY 1985 through FY 1998. The figure also breaks out the amount of Btu lost through the generation and transmission processes and amount of Btu delivered to the site. In FY 1998, electricity consumption, including energy used at the source of generation, accounted for approximately 71.3 percent $(510,063.4$ billion Btu) of the total primary Btu consumed in buildings and facilities (715,550.4 billion Btu; see Table 4-A). Of this amount, approximately 29.4 percent or 150.0 trillion Btu reached the site of use. The remaining 70.6 percent, 360.0 trillion Btu, was lost during the generation and transmission processes.

\section{FIGURE 6}

\section{Consumption of Electricity and Other Fuels in Buildings/Facilities,} FY 1985 through FY 1998

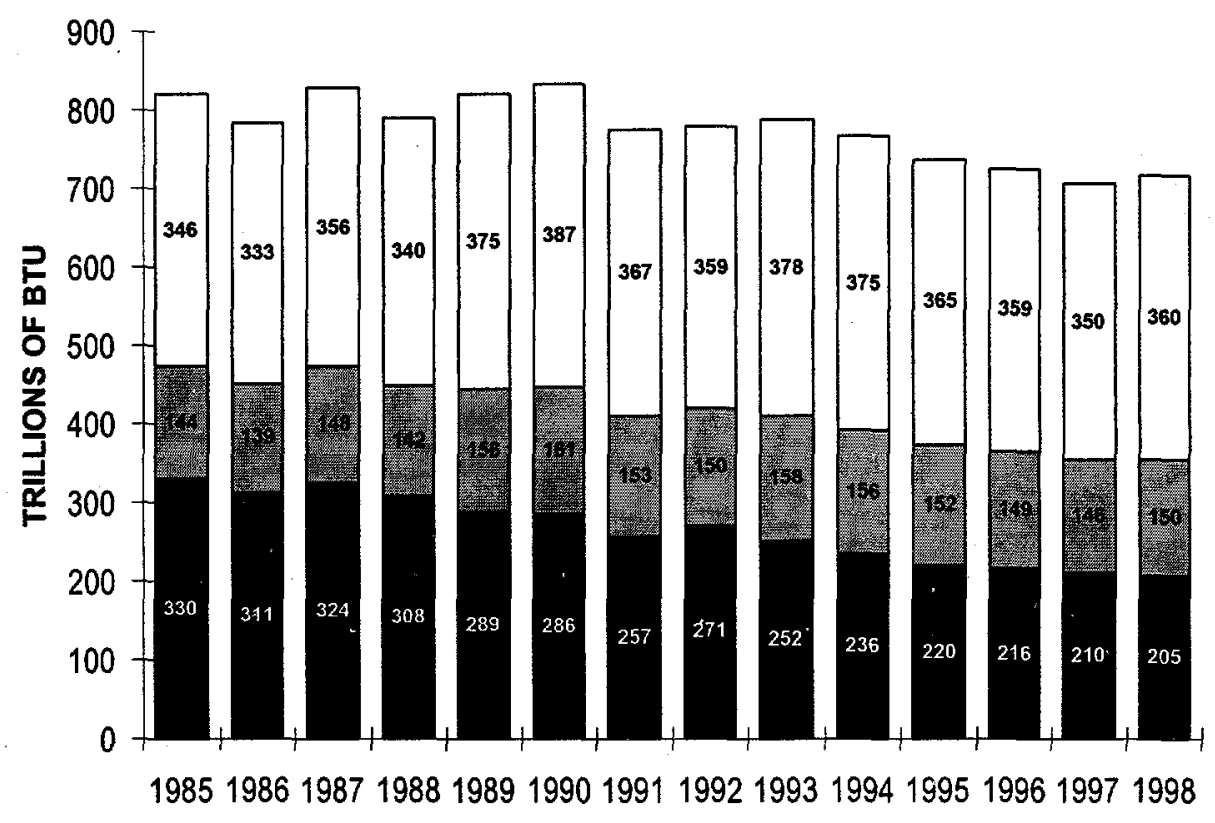

FISCAL YEAR

- Non-Electric Fuels1 1 Site Electricity2 $\square$ Conversion Losses3

'Includes Fuel Oil, Natural Gas, LPG/Propane, Coal, Purchased Steam, and Other. Uses a conversion factor for steam of 1,390 Btu per pound (source conversion).

${ }^{2}$ Uses a conversion factor of 3,412 Btu per kilowatt hour. Amount of energy which reaches the site of use when generation and transmission losses are subtracted.

${ }^{3}$ Amount of energy lost through generation and transmission processes. When added to amount of energy reaching the point of use, the total equals amount of Btu consumed at the source. The source conversion factor is 11,600 Btu per kilowatt hour.

Source: Federal Agency Annual Energy Management Data Reports 
Decreases in consumption relative to FY 1997 were seen in fuel oil (5.7 percent), purchased steam ( 0.1 percent), natural gas ( 2.2 percent), and fuels reported under the category of "other" ( 34.0 percent). Increases from the previous year were seen in electricity ( 3.0 percent), LPG/propane ( 24.4 percent), and coal (2.0 percent).

The mix of fuels consumed by Government buildings has changed notably from FY 1985 through FY 1998. The actual consumption of electricity has remained fairly steady since FY 1985, with an increase of 4.0 percent in FY 1998 while square footage has declined 8.8 percent. However, the proportion of energy consumed in Federal buildings and facilities that is electricity has increased from 30.6 percent in FY 1985 to 42.9 percent in FY 1998. Over the same period, fuel oil use decreased from 22.9 percent of the total in FY 1985 to only 10.7 percent in FY 1998. The portion of the Federal buildings fuel mix comprised by natural gas has increased from 30.7 percent in FY 1985 to 35.3 percent in FY 1998. The use of coal as a fuel source, which accounted for 12.3 percent of the total energy consumed in FY 1985, has declined to 5.5 percent of the total in FY 1998. Contributing to this has been the practice of agencies, such as DOE, to purchase steam rather than generating their own in coal-fired plants.

As shown in Table 5, the consumption of petroleum-based fuels in buildings during FY 1998 decreased 63.7 percent compared to FY 1985 and 4.0 percent from FY 1997. Efforts by agencies to utilize natural gas as a cost-effective substitute for petroleurn-based fuels in buildings, as well as conservation of fuel oil and LPG/propane in buildings contributed to these reductions.

Petroleum fuel consumption in buildings during FY 1998 represented only 11.5 percent of all energy consumed in Federal buildings. Of this amount, 92.6 percent is attributed to fuel oil and the remaining 7.4 percent to $\mathrm{LPG} /$ propane.

The energy used in buildings in FY 1998 accounted for approximately 41.5 percent of the total Federal energy bill. Tables 6-A and 6-B show that the Federal Government spent approximately $\$ 3,530.3$ million for buildings energy during the fiscal year, a decrease in constant dollars of approximately $\$ 61.8$ million from FY 1997 expenditures. The combined cost of buildings energy in FY 1998 was $\$ 10.10$ per million Btu, down 1.6 percent from the combined cost of $\$ 10.27$ reported in FY 1997.

Figure 7 illustrates energy expenditures for buildings and facilities from FY 1985 through FY 1998. In constant 1998 dollars, Federal energy costs for buildings and facilities decreased 38.4 percent from $\$ 5,732.0$ million in FY 1985 to $\$ 3,530.3$ million in FY 1998 . The combined cost for buildings energy in constant dollars in FY 1998 was $\$ 10.10$ per million Btu, down 17.0 percent from \$12.17 per million Btu in FY 1985.

FIGURE 7

Energy Costs (Constant 1998 Dollars) in Buildings and Facilities, FY 1985 through FY 1998

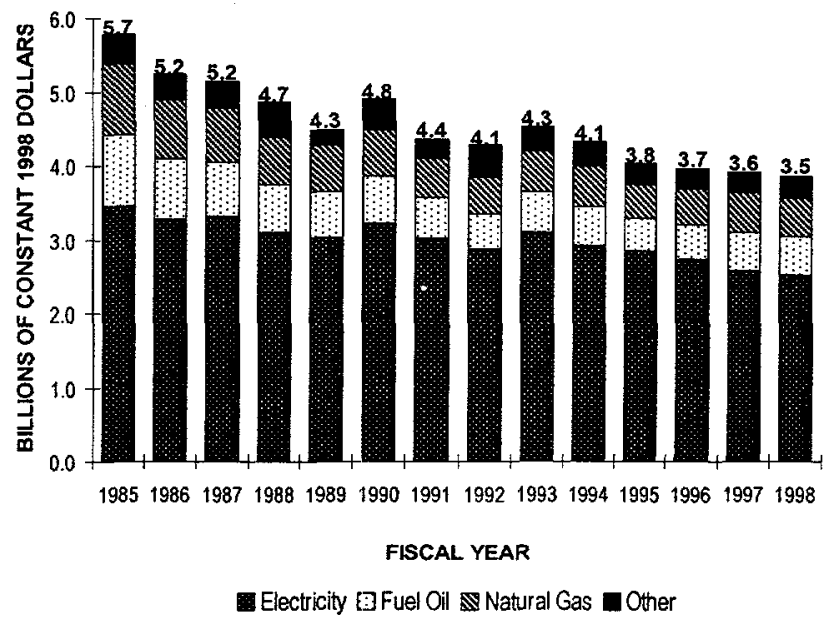


TABLE 5

PETROLEUM-BASED FUEL* CONSUMPTION IN BUILDINGS AND FACILITIES

(In Billions of Btu)

\begin{tabular}{|c|c|c|c|c|c|c|c|c|c|c|c|c|}
\hline $\begin{array}{l}\text { CIVILIAN } \\
\text { AGENCY }\end{array}$ & $\begin{array}{c}F Y \\
1985\end{array}$ & $\begin{array}{c}\text { FY } \\
1990\end{array}$ & $\begin{array}{c}F Y \\
1991\end{array}$ & $\begin{array}{c}F Y \\
1992\end{array}$ & $\begin{array}{c}\text { FY } \\
1993\end{array}$ & $\begin{array}{c}F Y \\
1994\end{array}$ & $\begin{array}{c}F Y \\
1995\end{array}$ & $\begin{array}{c}F Y \\
1996\end{array}$ & $\begin{array}{c}\text { FY } \\
1997\end{array}$ & $\begin{array}{c}\text { FY } \\
1998\end{array}$ & $\begin{array}{c}\% \text { CHANGE } \\
85-98\end{array}$ & $\begin{array}{c}\% \text { CHANGE } \\
97-98\end{array}$ \\
\hline DOD & $96,817.3$ & $69,030.1$ & $59,451.5$ & $65,654.1$ & $55,585.9$ & $50,285.7$ & $42,939.0$ & $42,861.7$ & $35,214.4$ & $32,354.5$ & -66.6 & -8.1 \\
\hline $\mathrm{ST}^{1}$ & 0.0 & 0.0 & 0.0 & 0.0 & 0.0 & 0.0 & 0.0 & 21.8 & 21.2 & $1,498.0$ & 0.0 & $6,958.9$ \\
\hline DOE & $1,650.8$ & $1,900.5$ & $2,063.7$ & $2,042.7$ & $1,943.5$ & $1,924.4$ & $1,973.5$ & $1,554.1$ & $1,394.0$ & $1,174.5$ & -28.8 & -15.7 \\
\hline VA & $2,176.7$ & $2,219.3$ & $1,404.9$ & $1,506.0$ & $1,533.9$ & $1,827.4$ & $1,292.9$ & $2,098.2$ & $1,186.3$ & 954.6 & -56.1 & -19.5 \\
\hline DOT & $2,376.9$ & $1,524.1$ & $1,308.4$ & $1,426.0$ & 854.0 & $1,001.6$ & 911.7 & 709.2 & 670.5 & 816.8 & -65.6 & 21.8 \\
\hline USPS & $1,673.2$ & $1,502,2$ & $\begin{array}{l}1,219.4 \\
1,219.4\end{array}$ & $\begin{array}{l}1,420.0 \\
1,195.8\end{array}$ & 988.8 & 983.7 & 813.9 & 595.2 & 819.0 & $1,139.4$ & -31.9 & 39.1 \\
\hline DOI & $1,591.6$ & $1,273.9$ & $1,141,1$ & 919.1 & $1,181.9$ & $1,560.6$ & $1,574.3$ & $1,177.7$ & 799.6 & 964.7 & -39.4 & 20.6 \\
\hline HHS & 2.246 .4 & 2.138 .7 & $1,545.9$ & $2,144.2$ & 1765.2 & $1,525.7$ & $1,152.5$ & 1718.8 & 760.7 & 498.6 & -77.8 & -34.5 \\
\hline DOL & 437.8 & 331.2 & 258.3 & 263.6 & 276.1 & 277.5 & 210.8 & 220.6 & 254.2 & 226.1 & -48.4 & -11.1 \\
\hline DOJ & 381.7 & 371.6 & 503.7 & 383.8 & 250.8 & 234.8 & 182.8 & 234.3 & 134.9 & 103.1 & -73.0 & -23.6 \\
\hline NASA & 230.2 & 277.8 & 161.6 & 217.6 & 129.0 & 139.6 & 88.6 & 110.9 & 88.3 & 93.5 & -59.4 & 5.8 \\
\hline USDA & 414.2 & 260.0 & 291.3 & 242.9 & 255.6 & 236.3 & 244.1 & 242.5 & 272.2 & 270.6 & -34.7 & -0.6 \\
\hline $\mathrm{ClA}$ & 0.0 & 0.0 & 0.0 & 0.0 & 0.0 & 0.0 & 49.6 & 87.9 & 84.6 & 60.2 & $N / A$ & -28.8 \\
\hline GSA & 991.3 & 668.1 & 443.1 & 418.2 & 359.4 & 379.8 & 199.0 & 242.3 & 143.0 & 54.8 & -94.5 & -61.7 \\
\hline TRSY & 22.5 & 281.3 & 127.7 & 84.2 & 190.5 & 160.8 & 116.6 & 116.2 & 57.0 & 44.8 & 99.4 & -21.5 \\
\hline EPA & 16.8 & 5.9 & 6.4 & 17.6 & 13.9 & 26.8 & 43.4 & 51.8 & 26.1 & 9.6 & -42.6 & -63.1 \\
\hline $\mathrm{DOC}$ & 130.3 & 77.6 & 13.1 & 9.8 & 23.8 & 52.4 & 10.8 & 33.4 & $\begin{array}{r}20.1 \\
9.3\end{array}$ & 8.7 & -93.3 & $\begin{array}{r}-0.1 \\
-7.1\end{array}$ \\
\hline TVA & 4.2 & 3.2 & 0.1 & 1.3 & 2.7 & 3.5 & 3.9 & 4.1 & 0.0 & 3.0 & -29.8 & $\mathrm{~N} / \mathrm{A}$ \\
\hline FCC & 1.7 & 1.9 & 1.0 & 1.3 & 1.3 & 1.3 & 1.3 & 1.7 & 1.7 & 1.7 & 0.8 & 0.0 \\
\hline OTHER ${ }^{\star *}$ & 76.1 & 83.7 & 59.1 & 67.2 & 67.6 & 49.1 & 49.1 & 57.3 & 60.9 & 58.0 & -23.8 & -4.8 \\
\hline TOTAL & $111,239.8$ & $81,951.0$ & $70,000.2$ & $76,595.5$ & $65,423.9$ & $60,671.0$ & $51,857.6$ & $52,139.7$ & $41,998.1$ & $40,335.3$ & -63.7 & -4.0 \\
\hline
\end{tabular}

*Petroleum-based fuels include fuel oil and LPG/propane.

**Other includes for certain years EEOC, FEMA, NSF, SSA, and USIA.

Note: FY 1997 and FY 1998 contains estimated data for the following agencies: FEMA, FTC, and OPM.

Sum of components may not equal total due to independent rounding.

${ }^{1}$ In 1998, the State Department developed a statistical method for estimating the energy consumption of its foreign buildings worldwide and included the estimate in their 1998 data.

Foreign building consumption has not been reported in full in previous years.

Source: Federal Agency Annual Energy Management Data Reports 
TABLE 6-A

DEFENSE AND CIVILIAN FEDERAL COSTS FOR BUILDINGS ENERGY IN FY 1998 (In Millions of Dollars)

$\begin{array}{lcccccccc} & \text { ELECTRICITY } & \text { FUEL OIL } & \begin{array}{c}\text { NATURAL } \\ \text { GAS }\end{array} & \begin{array}{c}\text { LPG/ } \\ \text { PROPANE }\end{array} & \text { COAL } & \begin{array}{c}\text { PURCHASED } \\ \text { STEAM }\end{array} & \text { OTHER } & \text { TOTAL } \\ \text { DEFENSE } & 1,416.214 & 160.999 & 296.726 & 14.569 & 32.943 & 163.328 & 0.732 & 2,085.510 \\ \text { CIVILIAN } & 1,146.103 & 29.605 & 193.516 & 11.453 & 5.558 & 55.199 & 3.363 & 1,444.797 \\ \text { TOTAL } & 2,562.317 & 190.604 & 490.242 & 26.022 & 38.501 & 218.527 & 4.095 & 3,530.307\end{array}$

AVERAGE COST PER UNIT, BASED ON REPORTS FROM AGENCIES

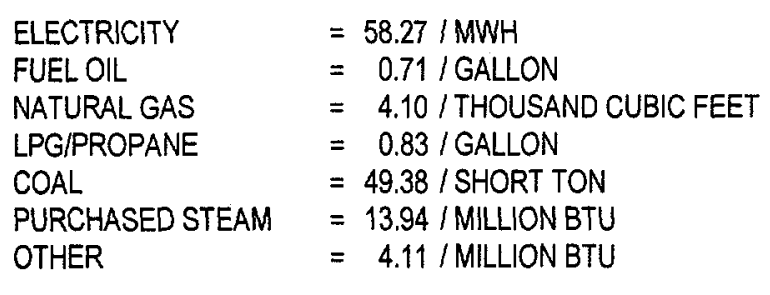

DATA AS OF 01/10/00

Note: Contains estimated data for the following agencies: FEMA, FCC, FTC, and OPM.

Sum of components may not equal total due to independent rounding.

Source: Federal Agency Annual Energy Management Data Reports. 


\section{TABLE 6-B}

CONSUMPTION AND COSTS OF FEDERAL BUILDINGS ENERGY

BY FUEL TYPE IN FY 1998, FY 1997, AND FY 1985

(Constant 1998 Dollars)

\begin{tabular}{|c|c|c|c|}
\hline ENERGY TYPE & $\begin{array}{c}\text { BILLIONS OF } \\
\text { BTU }\end{array}$ & $\begin{array}{l}\text { COST PER } \\
\text { MMBTU }\end{array}$ & $\begin{array}{c}\text { COST (IN MLLLIONS } \\
\text { OF DOLLARS) }\end{array}$ \\
\hline \multicolumn{4}{|l|}{ FY 1998} \\
\hline ELECTRICITY & $150,029.0$ & 17.0788 & $2,562.317$ \\
\hline FUEL OIL & $37,334.7$ & 5.1053 & 190.604 \\
\hline NATURAL GAS & $\{23,203.7$ & 3.9791 & 490.242 \\
\hline LPG/PROPANE & $3,000.6$ & 8.6724 & 26.022 \\
\hline COAL & $19 ; 162.8$ & 2.0092 & 38.501 \\
\hline PURCHASED STEAM & $15,676.0$ & 13.9402 & 218.527 \\
\hline OTHER & 995.7 & 4.1126 & 4.095 \\
\hline TOTAL & $349,402.4$ & & $3,530.307$ \\
\hline \multicolumn{4}{|c|}{ AVERAGE COST PER MMBTU $=\$ 10.104$} \\
\hline \multicolumn{4}{|l|}{ FY 1997} \\
\hline ELECTRICITY & $145,649.3$ & 17.7247 & $2,581.602$ \\
\hline FUEL OIL & $39,586.6$ & 5.0358 & 199.351 \\
\hline NATURAL GAS & $126,032.2$ & 4.1567 & 523.879 \\
\hline LPG/PROPANE & $2,411.5$ & 9.2790 & 22.377 \\
\hline COAL & $18,790.9$ & 2.1725 & 40.823 \\
\hline PURCHASED STEAM & $15,696,0$ & 13.6868 & 214.827 \\
\hline OTHER & $1,508.5$ & 6.1513 & 9.279 \\
\hline TOTAL & $349,675.1$ & & $3,592,137$ \\
\hline \multicolumn{4}{|c|}{ AVERAGE COST PER MMBTU $=\$ 10.273$} \\
\hline \multicolumn{4}{|l|}{ FY 1985} \\
\hline ELECTRICITY & $144,247.9$ & 23.9996 & $3,461.894$ \\
\hline FUEL OIL & $107,628.1$ & 8.5428 & 919.446 \\
\hline NATURAL GAS & $144,759.3$ & 6.6172 & 957.905 \\
\hline LPG/PROPANE & $3,611.7$ & 9.9095 & 35.791 \\
\hline COAL & $58,069.5$ & 3.3674 & 195.547 \\
\hline PURCHASED STEAM & $7,969.8$ & 16.1687 & 128.861 \\
\hline OTHER & $4,709.9$ & 6.9132 & 32.564 \\
\hline TOTAL & $470,996.2$ & & $5,732.004$ \\
\hline
\end{tabular}

AVERAGE COST PER MMBTU $=\$ 12.169$

DATA AS OF 01/10/00

Note: $\quad$ FY 1997 contains estimated data for the following agencies: FEMA, FTC, and OPM; FY 1998 contains estimated data for: FEMA, FCC, FTC, and QPM.

This table uses a conversion factor for electricity of 3,412 Btu per kilowatt hour. Sum of components may not equal total due to independent rounding.

Source: Federal Agency Annual Energy Management Data Reports 
Electricity costs of $\$ 2,562.3$ million represent approximately 72.6 percent of total expenditures of $\$ 3,530.3$ million for buildings energy in FY 1998. Natural gas costs account for approximately 13.9 percent of the total, expenditures for fuel oil account for 5.4 percent, with the remaining 8.1 percent attributable to expenditures for LPG/propane, coal, purchased steam, and "other."

In FY 1998, the cost of all energy used in Federal buildings was $\$ 1.15$ per gross square foot. Of the $\$ 1.15$ spent per square foot Government-wide, $\$ 0.83$ was spent for electricity, $\$ 0.16$ was spent for natural gas, $\$ 0.06$ was spent for fuel oil, and the remaining $\$ 0.10$ was spent for purchased steam, coal, LPG/propane, and other fuels.

\section{B. Progress Toward the Mandated Goals for Buildings and Facilities}

Both the magnitude of energy consumption and the potential for energy savings have prompted legislative and executive branch initiatives to achieve energy conservation in the Federal buildings sector. ${ }^{14}$ Federal Government progress toward the 10,20, and 30 percent energy reduction goals of NECPA and Executive Order 12902 is illustrated in Figure 8. Overall, the Federal Government reduced its net energy consumption in buildings and facilities by 18.7 percent in FY 1998 compared to FY 1985 when measured in terms of British Thermal Units consumed per gross square foot (Btu/GSF) of floor area.

FIGURE 8

Progress Toward the Energy Reduction Goals for Federal Buildings and Facilities, FY 1985 through FY 1998

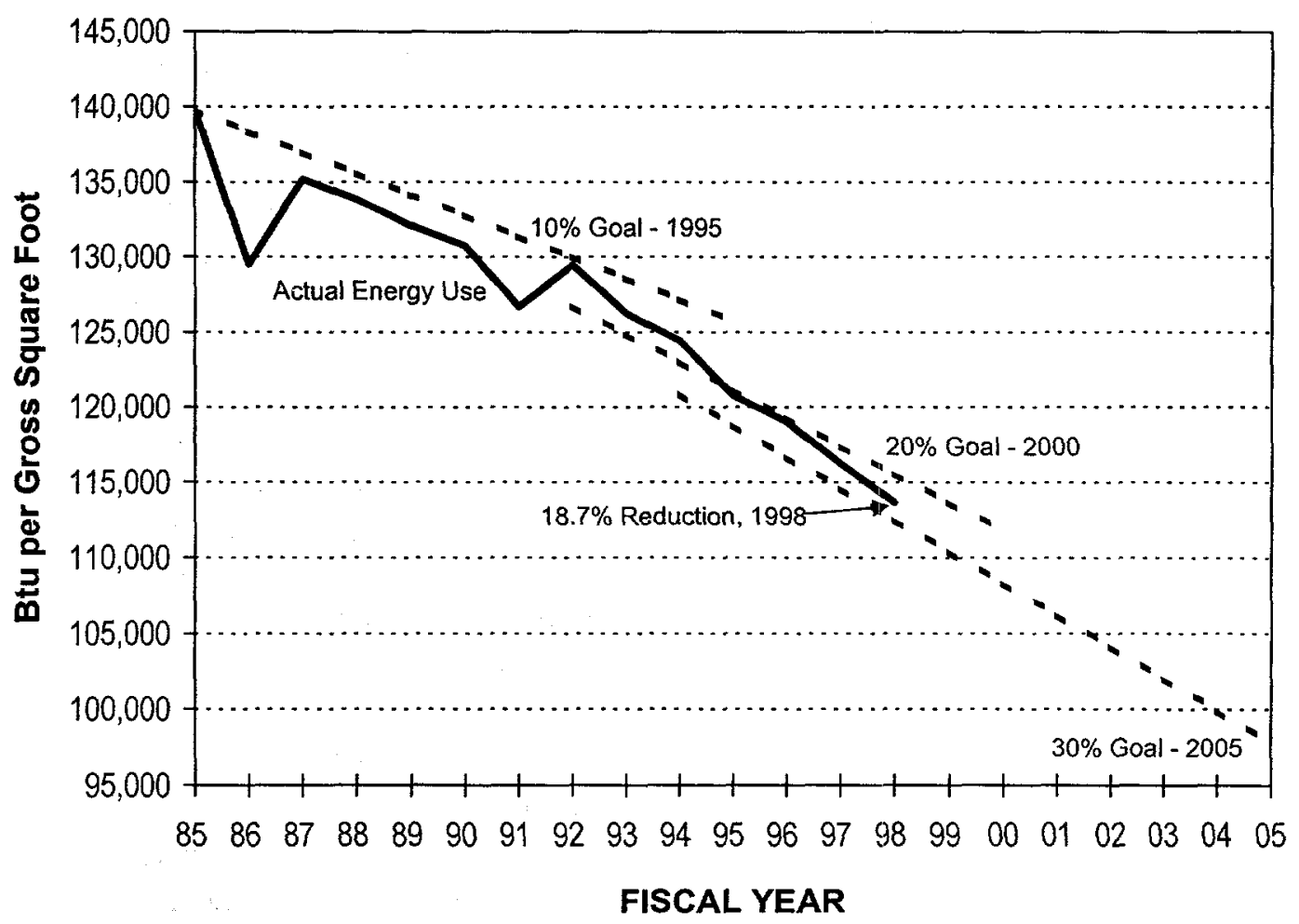

${ }^{14}$ The legislative authorities for Federal agencies are detailed in Appendix A. 
Table 7-A shows the FY 1998 performance of the individual agencies in net Btu/GSF compared to FY 1985. Net Btu reflects the amount of energy delivered to the point of use and is used to measure agency performance toward the mandated goals.

Table 7-B shows the performance of the agencies measured in terms of primary Btu/GSF. Primary Btu represents the average amount of energy required at the source of generation (primary energy) rather than the actual Btu delivered to the site. Primary Btu includes energy resources used to generate, process, and transport electricity and steam. Measured in terms of source energy, the Federal Government shows a reduction of 4.4 percent in FY 1998 compared to FY 1985. This large difference from the net Btu/GSF reduction of 18.7 percent reflects the significant declines in direct use of fossil fuels and the offsetting increases in the share of the fuel mix contributed by electricity.

Contributing to the overall reduction of 18.7 percent in net Btu/GSF were the percentage reductions greater than 10 percent made by the following 14 agencies: the Departments of Agriculture, Defense, the Interior, Commerce, Energy, Justice, Veterans Affairs, Housing and Urban Development, Transportation, and the General Services Administration, National Aeronautics and Space Administration, Environmental Protection Agency, the Tennessee Valley Authority, and the United States Postal Service.

These agencies used a variety of strategies to reduce their energy consumption. Operations and maintenance $(\mathrm{O} \& \mathrm{M})$ procedures continued to be emphasized as a major component in the effort to achieve the energy reduction goals. Improvements in energy efficiency were achieved through improved energy systems operations and both preventive maintenance and improved maintenance. O\&M funding, used for the replacement of boilers, HVAC equipment, windows, and lighting systems, continued to benefit energy conservation.

In FY 1998, the implementation of many no-cost and low-cost energy conservation measures was continued, such as reducing lighting levels, lowering hot water temperatures, turning off unused equipment, and installing energy-efficient windows, insulation, weather stripping, and set-back thermometers.

Numerous energy-efficient building retrofits and energy conservation projects were undertaken to supplement the no-cost, low-cost measures. These initiatives can be categorized by lighting system replacement, HVAC equipment modernization, building envelope improvements, and other miscellaneous projects, such as installation of energy management control systems. Utilitysponsored demand side management programs were often pursued as supplemental sources of funding, as well as energy savings performance contract initiatives.

Other activities include energy awareness programs featuring energy awareness seminars, the identification of no-cost or low-cost measures, the designation of building energy monitors, publication of materials promoting energy efficiency, the procurement of energy-efficient goods and products, increased maintenance training, and increased engineering assistance. 
TABLE 7-A

FEDERAL BUILDINGS AND FACILITIES NET ENERGY USE PER GROSS SQUARE FOOT, FY 1985 AND FY 1998

FISCAL YEAR 1985

\begin{tabular}{|c|c|c|c|c|c|c|c|}
\hline & $\begin{array}{c}\text { GSF } \\
\text { (Thousands) }\end{array}$ & $\begin{array}{c}\text { BTU } \\
\text { (Billions) }\end{array}$ & BTU/GSF & $\begin{array}{c}\text { GSF } \\
\text { (Thousands) }\end{array}$ & $\begin{array}{c}\text { BTU } \\
\text { (Billions) }\end{array}$ & BTU/GSF & $\begin{array}{l}\% \text { CHANGE } \\
1985-1998\end{array}$ \\
\hline VA & $123,650.0$ & $24,552.0$ & 198,560 & $153,813.5$ & $26,216.9$ & 170,446 & -14.2 \\
\hline DOE & $.73,415.8$ & $32,923.2$ & 448,449 & $81,253.9$ & $23,126.7$ & 284,623 & -36.5 \\
\hline USPS & $189,400.0$ & $16,238.3$ & 85,736 & $323,221.1$ & $22,683.9$ & 70,181 & -18.1 \\
\hline GSA & $196,341.4$ & $16,563.0$ & 84,358 & $186,125.0$ & $13,123.7$ & 70,510 & -16.4 \\
\hline DOJ & $20,768.8$ & $6,112.0$ & 294,289 & $44,240.1$ & $7,783.0$ & 175,926 & -40.2 \\
\hline ST & $2,597.0$ & 232.1 & 89,390 & $44,905.6$ & $7,422.7$ & 165,296 & 84.9 \\
\hline HHS & $22,317,3$ & $5,837.3$ & 261,558 & $26,115.9$ & $6,953.1$ & 266,239 & 1.8 \\
\hline NASA & $11,509.1$ & $3,095.7$ & 268,977 & $19,789.5$ & $3,941.4$ & 199,164 & -26.0 \\
\hline DOI & $54,154.4$ & $4,762.4$ & 87,940 & $50,502.7$ & $3,747.4$ & 74,202 & -15.6 \\
\hline DOT & $32,007.8$ & $4,500.3$ & 140,599 & $33,582.2$ & $3,667.9$ & 109,220 & -22.3 \\
\hline DOL & $18,268.3$ & $2,153.0$ & 117,852 & $18,582.5$ & $2,190.2$ & 117,862 & 0.0 \\
\hline USDA & $24,709.9$ & $2,096.3$ & 84,837 & $28,919.6$ & $2,111.1$ & 72,999 & -14.0 \\
\hline TRSY & $5,776.9$ & 615.0 & 106,463 & $12,017.0$ & $1,741.2$ & 144,895 & 36.1 \\
\hline EPA & $1,931.2$ & 772.3 & 399,923 & $2,875.1$ & $1,022.9$ & 355,780 & -11.0 \\
\hline TVA & $4,886.6$ & 402.4 & 82,357 & $9,747.9$ & 658.4 & 67,539 & -18.0 \\
\hline DOC & $4,522.6$ & 540.3 & 119,476 & $5,544.0$ & 429.9 & 77,541 & -35.1 \\
\hline HUD & $1,432.0$ & 116.9 & 81,668 & $1,432.0$ & 103.1 & 71,998 & -11.8 \\
\hline FCC & 121.0 & 11.2 & 92,182 & 124.8 & 12.8 & 102,204 & 10.9 \\
\hline PCC & 492.5 & 26.6 & 54,079 & 0.0 & 0.0 & 0 & -100.0 \\
\hline OTHER* & $2,558.5$ & 369.0 & 144,232 & $16,762.0$ & $1,898.7$ & 113,276 & -21.5 \\
\hline \multicolumn{8}{|c|}{ CIVILIAN AGENCIES } \\
\hline TOTAL & $790,861.1$ & $121,919.5$ & 154,160 & $1,059,554.4$ & $128,834.8$ & 121,593 & -21.1 \\
\hline DOD & $2,578,984.0$ & $349,076.7$ & 135,354 & $2,014,747.6$ & $220,567.6$ & 109,477 & -19.1 \\
\hline TOTAL & $3,369,845.1$ & $470,996.2$ & 139,768 & $3,074,302.0$ & $349,402.4$ & 113,653 & -18.7 \\
\hline
\end{tabular}

FISCAL YEAR 1998

*Other includes the Federal Trade Commission, Federal Emergency Management Agency, National Archives and Records Administration, National Science Foundation, Nuclear Regulatory Commission, Office of Personnel Management, Railroad Retirement Board, the U.S. Information Agency, and the Federal Energy Regulatory Commission.

Note: This table uses a conversion factor for electricity of 3,412 Btu per kilowatt hour.

Sum of components may not equal total due to independent rounding.

${ }^{1}$ In 1998, the State Department developed a statistical method for estimating the energy consumption of its foreign buildings worldwide and included the estimate in their 1998 data. Foreign building consumption has not been reported in full in previous years.

Source: Federal Agency Annual Energy Management Data Reports 
TABLE 7-B

FEDERAL BUILDINGS AND FACILITIES PRIMARY ENERGY USE PER GROSS SQUARE FOOT, FY 1985 AND FY 1998

FISCAL YEAR 1985

GSF

USPS

DOE

VA

GSA

ST

DOJ

HHS

NASA

DOT

DOI

USDA

TRSY

DOL

TVA

EPA

DOC

HUD

FCC

PCC

OTHER *
(Thousands)

BTU

(Billions) BTU/GSF

$189,400.0$

$73,415.8$

$123,650.0$

$196,341.4$

$2,597.0$

$20,768.8$

$22,317.3$

$11,509.1$

$32,007.8$

$54,154.4$

$24,709.9$

$5,776.9$

$18,268.3$

$4,886.6$

$1,931.2$

$4,522.6$

$1,432.0$

121.0

492.5

$2,558.5$
$39,441.0$

$57,430.1$

$42,333.7$

$41,207.0$

689.2

$8,962.7$

$10,458.1$.

$6,810.9$

$8,298.7$

$8,432.5$

$4,347.2$

$1,451.0$

$3,687.8$

$1,321.0$

$1,618.3$

$1,189.1$

349.3

29.5

90.5

947.5
208,242

782,258

342,367

209,874

265,377

431,545

468,609

591,783

259,270

155,713

175,929

251,178

201,871

270,333

838,001

262,925

243,951

244,132

183,854

370,333
FISCAL YEAR 1998

\begin{tabular}{rrrr}
\multicolumn{1}{c}{$\begin{array}{c}\text { GSF } \\
\text { (Thousands) }\end{array}$} & $\begin{array}{c}\text { BTU } \\
\text { (Billions) }\end{array}$ & BTU/GSF & $\begin{array}{r}\text { \%CHANGE } \\
1985-1998\end{array}$ \\
$323,221.1$ & $56,049.9$ & 173,410 & -16.7 \\
$81,253.9$ & $48,980.3$ & 602,806 & -22.9 \\
$153,813.5$ & $48,899.3$ & 317,913 & -7.1 \\
$186,125.0$ & $34,469.9$ & 185,197 & -11.8 \\
$44,905.6$ & $18,863.1$ & 420,061 & 58.3 \\
$44,240.1$ & $15,263.0$ & 345,004 & -20.1 \\
$26,115.9$ & $13,966.9$ & $\mathbf{5 3 4 , 8 0 4}$ & 14.1 \\
$19,789.5$ & $10,066.4$ & 508,673 & -14.0 \\
$33,582.2$ & $8,547.1$ & $\mathbf{2 5 4 , 5 1 2}$ & -1.8 \\
$50,502.7$ & $7,422.2$ & 146,966 & -5.6 \\
$28,919.6$ & $4,969.0$ & $\mathbf{1 7 1 , 8 2 0}$ & -2.3 \\
$12,017.0$ & $4,553.5$ & 378,918 & 50.9 \\
$18,582.5$ & $4,109.4$ & 221,145 & 9.5 \\
$9,747.9$ & $2,220.2$ & $\mathbf{2 2 7 , 7 5 9}$ & -15.7 \\
$2,875.1$ & $2,083.4$ & $\mathbf{7 2 4 , 6 3 1}$ & -13.5 \\
$5,544.0$ & $1,207.8$ & $\mathbf{2 1 7 , 8 6 0}$ & -17.1 \\
$1,432.0$ & 310.4 & $\mathbf{2 1 6 , 7 8 2}$ & -11.1 \\
124.8 & 31.7 & $\mathbf{2 5 3 , 8 3 8}$ & 4.0 \\
0.0 & 0.0 & 0 & -100.0 \\
$16,762.0$ & $5,045.0$ & $\mathbf{3 0 0 , 9 7 6}$ & -18.7 \\
& & & \\
$1,059,554.4$ & $287,058.3$ & $\mathbf{2 7 0 , 9 2 4}$ & -10.4 \\
& & & -5.6 \\
$2,014,747.6$ & $428,492.1$ & $\mathbf{2 1 2 , 6 7 8}$ & \\
& & & -4.4 \\
$3,074,302.0$ & $715,550.4$ & $\mathbf{2 3 2 , 7 5 2}$ & \\
& & & DATA AS OF 01/10/00
\end{tabular}

CIVILIAN AGENCIES

$\begin{array}{lrllllll}\text { TOTAL } & 790,861.1 & 239,095.2 & 302,323 & 1,059,554.4 & 287,058.3 & 270,924 & -10.4 \\ \text { DOD } & 2,578,984.0 & 581,170.2 & 225,349 & 2,014,747.6 & 428,492.1 & 212,678 & -5.6 \\ \text { TOTAL } & 3,369,845.1 & 820,265.5 & 243,413 & 3,074,302.0 & 715,550.4 & 232,752 & -4.4 \\ & & & & & & \text { DATA AS OF 01/10/00 }\end{array}$

*Other includes the Federal Trade Commission, Federal Emergency Management Agency, National Archives and Records Administration, National Science Foundation, Nuclear Regulatory Commission, Office of Personnel Management, Railroad Retirement Board, the U.S. Information Agency, and the Federal Energy Regulatory Commission.

Note: This table uses a conversion factor for electricity of 11,600 Btu per kilowatt hour and 1,390 Btu per pound of steam. Sum of components may not equal total due to independent rounding.

${ }^{1}$ In 1998, the State Department developed a statistical method for estimating the energy consumption of its foreign buildings worldwide and included the estimate in their 1998 data. Foreign building consumption has not been reported in full in previous years.

Source: Federal Agency Annual Energy Management Data Reports 
A number of agencies began submitting energy data to DOE starting in FY 1989 in compliance with NECPA as amended by the Federal Energy Management Improvement Act of 1988 (Pub. L. 100-615). Among these agencies are the Department of State, the Office of Personnel Management, and the Federal Energy Regulatory Commission. These three agencies submitted historical energy data back to FY 1985.

For FY 1990 and forward, Federal Energy Regulatory Commission energy consumption is reported as part of DOE and is therefore grouped under the category of "Other." Other agencies grouped under the category of "Other" in the tables had no buildings data to report for FY 1985. These agencies include the Federal Trade Commission, the National Archives and Records Administration, the Nuclear Regulatory Commission, the Railroad Retirement Board, and the U.S. Information Agency. The National Science Foundation, Federal Emergency Management Agency, and Office of Personnel Management also are grouped under this category due to lack of reporting in more recent years.

In FY 1998, GSA continued to delegate building management authority to agencies that occupy buildings owned and operated by GSA. As a result, several agencies reported increased gross square footage and energy consumption relative to FY 1985, while GSA reported decreases in these categories during the same period. The GSA delegation accounts for the significant interyear changes in energy consumption reported by various individual agencies. Two agencies, the Department of Health and Human Services and the Department of Commerce, adjusted their baseline year consumption and GSF figures during FY 1988 to reflect GSA delegations. DOC added the Jeffersonville Federal Center to its data reports, which greatly increased its gross square footage. In addition, three Commerce Bureaus, the Bureau of Economic Affairs, the National Technical Information Service, and the Patent and Trademark Office, all became eligible for reporting in FY 1989 as a result of leasing delegation.

The Treasury Department's large increase in buildings energy consumption since FY 1985, is a result of the addition of the Internal Revenue Service delegated buildings to the Department's building inventory. Also contributing to the Treasury's increase was the additions, in FY 1989, of the Office of Thrift Supervision's square footage and the GSA delegation of building management authority for the Financial Management Service. The energy consumption and square footage for these delegated buildings were included in GSA's FY 1985 reports.

The State Department's increase of 84.9 percent is attributable to the addition of the complete Foreign Buildings Service inventory to State's gross square footage and consumption. This increased the State Department's square footage 17-fold in FY 1998 compared to FY 1985.

In FY 1998, the Department of Health and Human Services completed a study of its FY 1985 energy consumption baseline and determined that the validity of the energy consumption data from the National Institutes of Health (NIH) for FY 1985 was suspect. However, the data for FY 1986 was complete and accurate. Square footages figures for the two years did not vary significantly. Therefore, NIH concluded that the data for FY 1986 portrayed an accurate and logical baseline for the energy consumption on a square foot basis. In addition, the baseline for the Office of the Secretary, Hubert H. Humphrey Building, was also adjusted, to the data for FY 1987 to account for a shift in building operation to 24 hours per day. The result of these baseline 
adjustments decreased the agency's FY 1985 baseline by 11 percent which in turn reflected a decrease in the agency's performance to the mandated reductions, despite the positive achievement of an 8 percent reduction in energy consumption from FY 1997 to FY 1998.

Figure 9 illustrates the range of energy intensity in agency buildings measured in terms of Btu/GSF. High rates of energy intensity at the EPA, HHS, and DOE reflect the special requirements of their laboratory and research facilities. At DOE, if more than 80 percent of a facility's metered energy is dedicated to process operations, then the entire facility's energy is excluded from the buildings category, according to how DOE defines its buildings and facilities. A large part of the HHS building inventory consists of laboratory and hospital facilities. However, the agency currently includes 100 percent of its facilities in the buildings category, that is, no highly energy intensive square footage has been excluded. For example, the NIH represents 61 percent of energy consumed by HHS and 45 percent of the total agency square footage. The NIH Main Campus in Bethesda, Maryland represents 75 percent of the total NIH space. The campus consists of energy intensive hospitals, laboratories, and animal centers that, while predominantly designed and built two to five decades ago, are currently some of the most technically advanced medical facilities in the nation. These highly intensive facilities operate 24 hours per day. The Interior Department's relatively low Btu/GSF results from the lack of energy intensive activities (i.e., laboratories, hospitals, etc.) in space under its control. The wide range of rates of Btu/GSF among different agencies is a result of the varying missions of the agencies as well as their varying criteria for excluding energy intensive facilities.

\section{Energy Star ${ }^{\circledR}$ Program Participation}

The Federal ENERGY STAR B Buildings Program Memorandum of Understanding (MOU) was signed by Mary Nichols, Environmental Protection Agency (EPA), and Christine Ervin, Assistant Secretary for Energy Efficiency and Renewable Energy, Department of Energy, in March 1997. 
During FY 1998, several Federal agencies took actions regarding both the Federal ENERGY

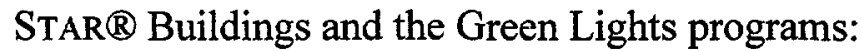

- Department of Defense-The Norfolk District, Army Corps of Engineers, in a joint demonstration with DOD and the EPA, developed a military housing design to achieve an "EPA 5 Star Energy Efficiency Rating" for 135 family housing units at Fort Lee, Virginia.

- Department of the Interior-In conjunction with EPA and DOE, DOI prepared a MOU to participate in the Federal ENERGY STAR $\otimes$ Program partnerships. This MOU was forwarded to the Interior's Assistant Secretary for Policy, Management and Budget.

- Department of Transportation-The United States Coast Guard is actively engaged in the development of eight ENERGY STAR $®$ buildings that will become showcase buildings upon project completion.

- Environmental Protection Agency-Several EPA facility construction projects demonstrate ENERGY STAR B Buildings technologies and concepts including the New Headquarters Buildings (Washington, DC), the New Consolidated RTP Facility (Research Triangle Park, NC), the Region IV Science and Ecosystems Support Laboratory (Athens, GA), Region IV Office (Atlanta, GA), Region III Office (Philadelphia, PA), Region VII Central Regional Laboratory (Kansas City, KS), National Vehicle and Fuel Emissions Laboratory (Ann Arbor, MI), and the Fort Meade Environmental Science Center (Fort Meade, MD).

- Department of Health and Human Services-The HHS Energy Officer and the operating division energy coordinators met with EPA to discuss the Federal ENERGY STAR $®$ Buildings program. Each HHS operating division will sign a MOU which will be forwarded to operating division heads with a cover letter encouraging participation from the Office of the Secretary's Assistant Secretary for Management and Budget.

- National Aeronautics and Space Administration-Both Goddard Space Flight Center and the Santa Susana Field Laboratory participate in the Green Lights program.

- Tennessee Valley Authority (TVA)-TVA is in the process of becoming a partner in the Federal ENERGY STAR B Buildings program. As a member of the Green Lights program, TVA developed the SWAP program to eliminate the cycle time for lighting upgrades and to reduce survey and design cost as part of these efforts. SWAP II, which will evaluate the implementation of lighting controls as a first step in the reduction of energy, will be initiated in FY 1998.

- United States Postal Service-Signed MOU with EPA to participate in the Federal ENERGY STARß Buildings program. 


\section{Federal Building Energy Performance Standards}

Federal agencies are subject to the provisions of 10 CFR part 435, subpart A, which set forth interim building energy performance standards for new Federal buildings. Standards for new Federal buildings are issued under the Energy Conservation Standards in New Buildings Act of 1976, as amended, 42 U.S.C. 6831 et seq, and under Title V, subtitle H, of the Energy Security Act, 42 U.S.C. $§ 8286$ and 8286a. On August 6, 1996, the Department of Energy issued a proposed rule in the Federal Register, 61 FR 40882, to revise the 1989 interim rule, 10 CFR part 435 , which established energy efficiency voluntary performance standards for design of new Federal commercial and multi-family high-rise residential buildings.

EPACT mandates that new Federal buildings must contain energy saving and renewable energy specifications that meet or exceed the energy saving and renewable energy specifications of the American Society of Heating, Refrigerating and Air Conditioning Engineers (ASHRAE)/ Illuminating Engineering Society of North America (IES) Standard 90.1-1989 and the Council of American Building Officials Model Energy Codes (MEC) 1992.

Furthermore, Executive Order 12902, which was designed to assist agencies in meeting or exceeding the Federal energy and water efficiency provisions contained in EPACT, requires each agency involved in the construction of a new facility that will be either owned by or leased to the Government to:

(1) design and construct such facility to minimize the life-cycle cost of the facility by utilizing energy efficiency, water conservation, or solar or other renewable energy technologies;

(2) ensure that the design and construction of facilities meet or exceed the energy performance standards applicable to Federal residential or commercial buildings as set forth in 10 CFR 435, local building standards, or a Btu-per-gross-square-foot ceiling as determined by the Task Force within 120 days of the date of this order, whichever will result in a lower life-cycle cost over the life of the facility;

(3) establish and implement, within 270 days of the date of this order, a facility commissioning program that will ensure that the construction of such facilities meets the requirements outlined in this section before the facility is accepted into the Federal facility inventory; and

(4) utilize passive solar design and adopt active solar technologies, where cost-effective.

The Department of Energy has endeavored to fulfill these requirements by developing common energy conservation standards for all new Federal buildings and by issuing life-cycle costing procedures for use by Federal agencies in the assessment of energy conserving investments for existing buildings.

In response to the Executive Order 12902 requirement for Federal agencies to establish and implement a facility commissioning program, DOE formed the New Space Working Group under the Federal Interagency Energy Management Task Force. The Working Group, in conjunction with GSA and other Federal agencies, drafted a Building Commissioning Guide 
which has been distributed to agencies for final comment. The Guide is designed to help all parties involved in the planning, design, construction, acceptance, and post-acceptance phases work together to produce a building that operates according to design intent and provides occupant comfort and energy savings. The draft Guide will be posted on the Federal Energy Management Program's Internet Web site at www.eren.doe.gov/femp for use during the review process.

A proposed rule, Energy Code for New Federal Commercial and Multi-Family High Rise Residential Buildings, revises the interim Federal standards to conform generally with the codified version of ASHRAE Standard 90.1-1989 and incorporates changes in the areas of lighting, mechanical ventilation, motors, building envelope, and fenestration rating procedures, and test procedures for heating and cooling equipment. Since Standard 90.1-1989 is written as a standard of professional practice, it cannot be directly adopted as a building code. DOE's New Space Working Group expressed concern that the Energy Code be concise as possible, publishing the minimal exceptions to the commercial standard, rather than publishing an entire new energy code. Using one standard would allow the architect/engineer community to focus on designing energy saving elements, rather than on implementing an unique Federal standard. The Working Group also recommended that an electronic version of the codified rule be placed on the Internet. The final version of the Energy Code is expected to be published by DOE in 2000 .

A separate proposed rule for new Federal residential buildings was issued by the Department of Energy in the Federal Register in May 1997. The proposed rule, Energy Code for New Federal Residential Buildings, uses the Model Energy Code (MEC) format and contains performance standards from the current Federal residential standard, the MEC, and the codified version of ASHRAE Standard 90.2-1993 that are economically justified and technologically feasible.

DOE has also worked closely with HUD in coordinating the technical factors and data used to develop HUD's Manufactured Housing Standards and has committed to work closely with all Federal agencies to coordinate and upgrade the standards applied by these agencies to nonFederal buildings.

DOE is concurrently working on a model commissioning plan based on a GSA plan for a Federal courthouse in Portland, Oregon. This model will be more detailed than the Building Commissioning Guide and will include forms, model plans, training, and acceptance procedures for the building. 


\section{ENERGY INTENSIVE OPERATIONS IN FEDERAL FACILITIES}

\section{A. Energy Consumption and Costs for Energy Intensive Operations}

NECPA, as amended, 42 U.S.C. $\S 8253$, allows agencies to exclude from the buildings goal, facilities which house energy intensive activities. The energy consumed in these facilities is reported under the category of excluded/process energy. The reporting of energy used in excluded buildings assures that total Federal energy consumption is monitored.

The designation of excluded buildings is at the discretion of each agency. Currently, 14 agencies are excluding specific facilities from the NECPA goal: the Departments of Agriculture, Commerce, Defense, Energy, Justice, State, Transportation, and the Treasury, the General Services Administration, the National Aeronautics and Space Administration, the National Archives and Records Administration, the Social Security Administration, the Tennessee Valley Authority, and the U.S. Information Agency. Lists of the excluded buildings that have been identified by the agencies are included in Appendix D.

Table 8 shows that fuels consumed by excluded/process energy have increased 66.6 percent compared to FY 1985 and 0.7 percent from FY 1997. During FY 1998, the Department of Defense consumed 36.6 trillion Btu of excluded/process energy, 55.5 percent of all excluded/process energy used by the Federal Government.

Some of the fluctuations in consumption of excluded/process energy resulted from agencies changing data collection and reporting procedures. The Social Security Administration began reporting its energy separately from the Department of Health and Human Services in FY 1996 and has elected to exclude check processing facilities as energy intensive. In FY 1994, the Tennessee Valley Authority began reporting electricity used for certain processes of its generating plants. The Department of Justice also commenced reporting energy consumption in its excluded buildings during FY 1994. Increases in consumption of excluded/process energy compared to FY 1985 is also partially attributable to DOD's reallocation, beginning in the FY 1988 reporting year, of energy previously reported in the buildings category to the process category. Also contributing to this increase was the Treasury Department's initial reporting of process energy in FY 1991. Treasury neither reported process energy prior to 1991 nor revised its building energy consumption prior to 1990 to exclude process energy. NASA began reporting process energy in FY 1989 and has revised its prior year data. As a result of the prioritization survey required by Executive Order 12902, NASA redesignated the entire Dryden Flight Research Center, virtually all of the White Sands Test Facility, and many individual facilities at the Goddard Space Flight Center and the Langley Research Center as non-exempt facilities in FY 1996. NASA also redesignated the entire Michoud Assembly Facility as an industrial facility. USIA also began reporting energy under this category in FY 1989. USIA has not reported any process energy consumption for any prior years. GSA began reporting energy in excluded buildings in FY 1990 and has backed out this energy consumption from its FY 1985 buildings data. The Departments of Agriculture and Commerce both began excluding buildings where energy intensive activities occur in FY 1992. USDA revised all of its prior year buildings data back to FY 1985 to reflect the exclusion of the Agricultural Research Service. The Commerce 


\section{TABLE 8}

FEDERAL NET ENERGY CONSUMPTION IN EXCLUDED BUILDINGS/PROCESS OPERATIONS (In Billions of Btu, with Conversions to Millions of Barrels of Oil Equivalent [MBOE], and Petajoules [Joule $\mathrm{x} 10^{15}$ ])

\begin{tabular}{|c|c|c|c|c|c|c|c|c|c|c|c|c|}
\hline $\begin{array}{l}\text { CIVILIAN } \\
\text { AGENCY }\end{array}$ & $\begin{array}{l}\text { FY } \\
1985\end{array}$ & $\begin{array}{c}\text { FY } \\
1990\end{array}$ & $\begin{array}{c}F Y \\
1991\end{array}$ & $\begin{array}{c}F Y \\
1992\end{array}$ & $\begin{array}{c}\text { FY } \\
1993\end{array}$ & $\begin{array}{c}\text { FY } \\
1994\end{array}$ & $\begin{array}{c}F Y \\
1995\end{array}$ & $\begin{array}{c}\text { FY } \\
1996\end{array}$ & $\begin{array}{c}\text { FY } \\
1997\end{array}$ & $\begin{array}{c}\text { FY } \\
1998\end{array}$ & $\begin{array}{c}\% \text { CHANGE } \\
85-98\end{array}$ & $\begin{array}{c}\% \text { CHANGE } \\
97-98\end{array}$ \\
\hline DOE & $16,401.6$ & $11,649.9$ & $11,541.3$ & $12,657.8$ & $10,900.5$ & $11,000.3$ & $17,236.2$ & $16,876.6$ & $8,209.1$ & $6,367.8$ & -61.2 & -22.4 \\
\hline NASA & $5,759.6$ & $7,135.0$ & $7,215.7$ & $7,327.6$ & $7,310.3$ & $7,590.9$ & $7,172.0$ & $6,210.8$ & $6,482.8$ & $6,347.4$ & 10.2 & -2.1 \\
\hline DOT & $2,885.1$ & $3,064.0$ & $3,323,0$ & $4,406.8$ & $4,703.8$ & $2,952.5$ & $2,349.4$ & $3,178.1$ & $3,024.6$ & $4,799.4$ & 66.4 & 58.7 \\
\hline USDA & $1,942.8$ & $2,204.2$ & $2,133.3$ & $1,966.3$ & $2,166.9$ & $2,119.3$ & $2,824.0$ & $2,140.8$ & $2,221.6$ & $2,416.5$ & 24.4 & 8.8 \\
\hline USPS & 0.0 & 0.0 & 0.0 & 0.0 & 0.0 & 0.0 & 0.0 & 0.0 & $1,974.4$ & $2,026.2$ & 0.0 & 2.6 \\
\hline$D O C$ & 938.6 & 0.0 & 0.0 & 976.6 & 770.8 & $1,110.2$ & $1,627.4$ & $1,823.0$ & $1,335.2$ & $1,332.0$ & 41.9 & -0.2 \\
\hline TVA & 0.0 & 0.0 & 0.0 & 0.0 & 0.0 & $1,390.6$ & $1,317.1$ & $1,235.6$ & $1,251.8$ & $1,208.4$ & 0.0 & -3.5 \\
\hline USIA & 0.0 & $1,406.9$ & 850.6 & 828.5 & 796.8 & 861.1 & 878.2 & 936.2 & $1,092.2$ & $1,020.4$ & 0.0 & -6.6 \\
\hline TRSY & 0.0 & 0.0 & $1,026.8$ & 814.1 & 923.7 & 771.8 & 941.0 & 928.3 & $1,131.8$ & 996.5 & 0.0 & -11.9 \\
\hline DOJ & 0.0 & 0.0 & 0.0 & 0.0 & 0.0 & 668.4 & 707.8 & 944.1 & 846.9 & 850.7 & 0.0 & 0.5 \\
\hline GSA & 623.6 & 160.6 & 746.2 & 677.6 & 994.6 & $1,060.2$ & $1,213.8$ & 961.0 & 890.7 & 849.2 & 36.2 & -4.7 \\
\hline NARA & 0.0 & 0.0 & 0.0 & 0.0 & 274.7 & 610.7 & 792.2 & 562.9 & 572.7 & 591.8 & 0.0 & 3.3 \\
\hline ST & 0.0 & 0.0 & 0.0 & 0.0 & 337.4 & 339.4 & 344.4 & 364.1 & 339.1 & 324.2 & 0.0 & -4.4 \\
\hline SSA & 0.0 & 0.0 & 0.0 & 0.0 & 0.0 & 0.0 & 0.0 & 215.5 & 204.7 & 211.4 & 0.0 & 3.3 \\
\hline PCC & 167.2 & 190.8 & 197.1 & 193.9 & 197.5 & 201.3 & 209.4 & 218.6 & 221.2 & 0.0 & -100.0 & -100.0 \\
\hline \multicolumn{13}{|c|}{ CIVILIAN AGENCIES } \\
\hline TOTAL & $28,718.3$ & $25,811.3$ & $27,033.9$ & $29,849.3$ & $29,377.0$ & $30,676.5$ & $37,612.7$ & $36,595.7$ & $29,798.8$ & $29,342.0$ & 2.2 & -1.5 \\
\hline DOD & $10,857.2$ & $39,209.1$ & $56,372.1$ & $67,913.1$ & $41,159.3$ & $39,781.4$ & $37,962.6$ & $37,260.1$ & $35,702.3$ & $36,588.4$ & 237.0 & 2.5 \\
\hline \multicolumn{13}{|c|}{ ALL AGENCIES } \\
\hline TOTAL & $39,575.5$ & $65,020.5$ & $83,406.1$ & $97,762.4$ & $70,536.3$ & $70,457.9$ & $75,575.3$ & $73,855.8$ & $65,501.1$ & $65,930.5$ & 66.6 & 0.7 \\
\hline MBOE & 6.8 & 11.2 & 14.3 & 16.8 & 12.1 & 12.1 & 13.0 & 12.7 & 11.2 & 11.3 & & \\
\hline ·Petajoules & 41.8 & 68.6 & 88.0 & 103.1 & 74.4 & 74.3 & 79.7 & 77.9 & 69.1 & 69.6 & & \\
\hline
\end{tabular}

Note: This table uses a conversion factor for electricity of 3,412 Btu per kilowatt hour. Sum of components may not equal total due to independent rounding.

Source: Federal Agency Annual Energy Management Data Reports 
Department revised its FY 1985 base year data only to reflect the exclusion of its energy intense facilities. The State Department and NARA began reporting excluded/process energy in FY 1993 and have not revised data for any prior years. The Justice Department commenced reporting of excluded buildings in FY 1994 and has not revised data for any prior years. The U.S. Postal Service began reporting energy consumption under this category in FY 1997 with no revisions to prior years.

Energy used in energy intensive operations accounts for approximately 6.3 percent of the total 1.04 quads used by the Federal Government. Electricity constitutes 52.9 percent of the energy used in energy intensive operations, 27.4 percent is accounted for by natural gas, 7.2 percent by coal, and 9.4 percent by fuel oil. Small amounts of purchased steam, liquefied petroleum gas (LPG)/propane, and "other" energy account for the remaining 3.1 percent.

The energy used in energy intensive operations in FY 1998 accounted for approximately 7.5 percent of the total Federal energy bill. Table 9 shows that the Federal Government spent approximately $\$ 621.3$ million for excluded/process energy during the fiscal year. The combined cost of excluded/process energy in FY 1998 was $\$ 9.42$ per million Btu, down 8.5 percent from the combined cost of $\$ 10.29$ reported in FY 1997 (see Appendix C).

\section{B. Statutory Background and Progress Toward Goals for Industrial Facilities}

Under section 543(a)(2) of NECPA, as amended by EPACT, 42 U.S.C. $\S 8253$, buildings that house energy-intensive activities may be excluded from NECPA's performance goal for buildings. These buildings are listed in Appendix D. Most energy used in excluded buildings is process energy. Process energy is consumed in industrial operations, certain R\&D activities, and in electronic-intensive facilities.

Executive Order 12759 expanded the scope of Federal energy management activities beyond the NECPA mandates by establishing goals for industrial operations. It required industrial facilities to increase energy efficiency by at least 20 percent by FY 2000 in comparison to FY 1985 to the extent that measures undertaken are cost-effective and minimize life-cycle costs. Executive Order 12902 changes this goal to require an increase in energy efficiency by at least 20 percent by 2005 as compared to 1990 . Measures undertaken to achieve this goal must be cost-effective, and agencies are also directed to implement all cost-effective water conservation projects. The Executive Order goal applies to certain buildings currently excluded under NECPA where industrial operations are performed. During FY 1994, a working group of the Interagency Energy Management Task Force concentrated efforts on developing appropriate indicators for measuring performance under this goal.

The Department of Defense excludes two types of energy from the NECPA performance goal: process energy and "cold iron" energy. Process energy is used in facilities that perform production or industrial functions. "Cold iron" energy is used to supply power to Navy ships docked in port. Both types of energy are included in this report under the category of excluded/process. 
TABLE 9

DEFENSE AND CIVILIAN FEDERAL COSTS FOR EXCLUDED BUILDINGS/ PROCESS ENERGY IN FY 1998

(In Millions of Dollars)

$\begin{array}{lccccccrr} & \text { ELECTRICITY } & \text { FUEL OIL } & \begin{array}{c}\text { NATURAL } \\ \text { GAS }\end{array} & \begin{array}{c}\text { LPG/ } \\ \text { PROPANE }\end{array} & \text { COAL } & \begin{array}{c}\text { PURCHASED } \\ \text { STEAM }\end{array} & \text { OTHER } & \text { TOTAL } \\ \text { DEFENSE }^{1} & 193.843 & 12.071 & 38.849 & 0.316 & 7.985 & 4.656 & 0.000 & 257.719 \\ \text { CIVILIAN }^{2} & 323.573 & 8.224 & 20.288 & 0.426 & 0.591 & 10.106 & 0.410 & 363.619 \\ \text { TOTAL } & 517.416 & 20.295 & 59.137 & 0.742 & 8.576 & 14.761 & 0.410 & 621.337\end{array}$

AVERAGE COST PER UNIT, BASED ON REPORTS FROM AGENCIES

$\begin{array}{llrll}\text { ELECTRICITY } & =50.58 & \text { MWH } \\ \text { FUEL OIL } & = & 0.45 & \text { GALLON } \\ \text { NATURAL GAS } & = & 3.38 & \text { THOUSAND CUBIC FEET } \\ \text { LPGIPROPANE } & =0.50 & \text { GALLON } \\ \text { COAL } & =44.54 & \text { SHORT TON } \\ \text { PURCHASED STEAM } & =7.94: \text { MLLLON BTU } \\ \text { OTHER } & =7.89 / \text { MILLION BTU }\end{array}$

DATA AS OF 07/10/98

${ }^{1}$ Includes DOD costs for process and cold iron energy.

${ }^{2}$ Includes DOE costs for metered process energy and energy costs for buildings excluded from performance

measurement by DOC, DOJ, DOT, GSA, NASA, NARA, PCC, SSA, STATE, TRSY, TVA, USDA, and USIA.

Note: Sum of components may not equal total due to independent rounding.

Source: Annual energy cost data submitted to DOE by Federal agencies. 
The Department of Energy reports its use of metered energy in extensive experimental research and production processes under excluded/process energy. The metered process energy used by DOE includes energy consumed in: production nuclear reactors, industrial-type operations for weapons and nuclear fuel production, and research and development facilities such as experimental nuclear reactors and linear accelerators. Excluded/process energy totaled almost 6.4 trillion Btu in FY 1998, which represents 20.2 percent of all energy consumed by DOE. The use of excluded process energy by DOE in FY 1998 was 61.2 percent less than in FY 1985, and 22.4 percent less than FY 1997. The primary contributor to the substantial drop beginning in FY 1997 was the sale by DOE of the Naval Petroleum Reserve, California, and subsequent decreases in natural gas consumption.

NASA excludes from the NECPA performance goal facilities which fall under its definition of mission-variable facilities. These highly specialized, energy-intensive facilities house space science experimental and testing activities, as well as some industrial operations. Examples of these facilities include wind tunnels driven by multi-thousand horsepower electric motors, launch facilities, space simulation chambers, space communication facilities, and research analysis centers. The Michoud Assembly Facility (MAF), which manufactures the Space Shuttle external tank, is the only NASA facility subject to the Executive Order goal for industrial facilities. MAF selected billion Btu (BBtu) per external tank as its industrial energy metric. In the FY 1990 baseline year, MAF total energy consumption was $925.8 \mathrm{BBtu}$ at a production rate of 4.6 external tanks per year, or 201.3 BBtu/external tank. In FY 1998, MAF total energy consumption was $1,008 \mathrm{BBtu}$ at a production rate of 7 external tanks per year, or $144 \mathrm{BBtu} / \mathrm{external}$ tank. This represents a 28.5 percent reduction in energy consumption per external tank produced and an energy efficiency improvement of 39.8 percent.

The Department of Commerce excludes buildings operated by three of its agencies: the National Institute of Standards and Technology (NIST), the National Oceanic and Atmospheric Administration (NOAA), and the Bureau of the Census. NIST installations have been excluded because they are comprised of general purpose and special laboratories that require constant environmental space control and base electrical loads for scientific equipment and computer systems. NOAA Weather Service facilities operate 24 hours a day and consist of radar towers, computers, special gauges, meters and other sophisticated equipment. Marine Fisheries and Laboratories conduct marine biology research and utilize refrigerators, freezers, incubators, coolers, seawater pumps, and compressors that operate 24 hours a day. The Bureau of Census Charlotte Computer Center is a leased facility and is used solely as a computer center. The building is operated 24 hours a day.

Within the Department of Transportation, the Federal Aviation Administration excludes all buildings involved in implementing the National Airspace System Plan. These buildings house energy-intensive electronic equipment with the associated HVAC requirements to maintain an environment for reliable equipment operation.

The U.S. Information Agency designates domestic and overseas Voice of America Relay Stations as energy-intensive facilities and reports this consumption as process energy excluded from the NECPA performance goal. 
A substantial amount of the energy consumption formerly reported by the Panama Canal Commission under this category was dedicated to process functions, primarily comprising the locks, industrial, and other canal ancillary or support facilities. PCC has ceased reporting energy data pending its abolishment on December 31, 1999.

The GSA excludes from the NECPA performance goal those buildings and facilities where energy usage is skewed significantly due to reasons such as: buildings entering or leaving the inventory during the year; buildings down-scaled operationally to prepare for disposal; buildings undergoing major renovation and/or major asbestos removal; or buildings functions like that of outside parking garages which consume essentially only lighting energy, yet are classed as buildings. GSA's excluded buildings, due to these factors, could distort GSA's actual progress toward meeting the energy reduction goal.

Energy reported by the Treasury Department under the category of excluded/process energy is comprised mainly of industrial energy consumption by the Bureau of Engraving and Printing and the Mint.

The State Department excludes unique, special-use facilities with special security and operational requirements including the President's guest house, a computer facility, the International Chancery Center, and the Main State Facility.

NARA designates all 12 of its facilities as energy intensive because of stringent records storage requirements which demand that documents and records be maintained in a controlled environment 24 hours per day, 365 days per year.

The Department of Justice excludes the Justice Data Center in Washington, DC, a 24-hour-a-day energy intensive facility and five installations operated by the Federal Bureau of Investigation which operate 24 hours per day. These facilities have limited conservation measures available. Also exempted by the Justice Department are Immigration and Naturalization Service repeater stations located nationwide that house equipment operations only.

The Social Security Administration, which began reporting energy consumption this year as an independent agency, has designated its National Computer Center as an energy intensive facility. The Center contains SSA's main database and query server and operates 24 hours per day and 365 days per year.

Since 1985, the Postal Service has deployed energy intensive automated equipment which has improved the efficiency of mail operations. Surveys indicate that this equipment deployment has increased process energy usage by 8 percent in FY 1998. The Postal Service energy consumption reported under this category reflects process energy consumed by mail processing equipment. This consumption has been factored out of energy consumption of Postal Service non-excluded buildings in order to provide a better measure of their energy efficiency status. 


\section{ENERGY MANAGEMENT IN VEHICLES AND EQUIPMENT}

\section{A. Energy Consumption and Costs for Vehicles and Equipment}

Vehicle and equipment energy consists of energy used by equipment ranging in size and function from aircraft carriers to forklifts. It includes aircraft and naval fuels, automotive fuels consumed by Federally-owned and leased vehicles and privately-owned vehicles used for official business, and the energy used in Federal construction.

Table 10 shows that in FY 1998, the Federal Government used approximately 627.7 trillion Btu of energy for vehicles and equipment, a decrease of 32.8 percent relative to FY 1985. DOD's vehicle and equipment energy consumption decreased 34.9 percent from FY 1985, while the civilian agencies increased consumption by 9.4 percent. Overall, vehicle and equipment consumption decreased 5.7 percent from FY 1997. Federal energy consumption in vehicles and equipment is at its lowest level since Federal agencies began reporting consumption in 1975 . This is mainly attributable to decreased operations by the Department of Defense.

Jet fuel consumption accounted for 71.0 percent of all vehicle and equipment energy in FY 1998. In FY 1998 compared to the previous year, jet fuel consumption decreased 6.3 percent from 475.7 trillion Btu to 445.5 trillion Btu.

Agencies have taken many tangible steps to keep the use of vehicle fuels to a minimum. For example, USPS continues to modernize its fleet, adding diesel delivery vans and long-life vehicles to its inventory, both of which are more fuel efficient than the older vehicles they replaced. DOD continues to increase the use of flight simulators, as well as the use of new propulsion technologies in order to lessen the growth of vehicle and equipment fuel consumption.

Increased mission activities accounted for higher levels of operations energy use by some agencies. The Commerce Department's significant increase in consumption during FY 1990 was due primarily to increased miles driven by Census personnel in conducting the 1990 Census. Energy consumption in DOC's vehicles has declined by 80.7 percent in FY 1998 from FY 1990.

Other fluctuations in consumption of vehicle fuels resulted from changes in data collection and reporting procedures. The significant decrease in vehicular fuel consumption compared to FY 1985 reported by the Department of Health and Human Services is the result of data collection difficulties which omitted from their reports fuel consumed by leased vehicles and privately-owned vehicles authorized for Government service after FY 1987. HHS reported no vehicles under the agency's control during FY 1990, FY 1991, and FY 1992. 
TABLE 10

FEDERAL ENERGY CONSUMPTION IN VEHICLE AND EQUIPMENT OPERATIONS

(In Billions of Btu, with Conversions to Millions of Barrels of Oil Equivalent [MBOE], and Petajoules [Joule $\mathrm{x} 10^{15}$ ])

\begin{tabular}{|c|c|c|c|c|c|c|c|c|c|c|c|c|}
\hline $\begin{array}{l}\text { CIVILIAN } \\
\text { AGENCY }\end{array}$ & $\begin{array}{l}\text { FY } \\
1985\end{array}$ & $\begin{array}{c}\text { FY } \\
1990\end{array}$ & $\begin{array}{l}\text { FY } \\
1991\end{array}$ & $\begin{array}{l}\text { FY } \\
1992\end{array}$ & $\begin{array}{c}\text { FY } \\
1993\end{array}$ & $\begin{array}{c}F Y \\
1994\end{array}$ & $\begin{array}{c}\text { FY } \\
1995\end{array}$ & $\begin{array}{c}F Y \\
1996\end{array}$ & $\begin{array}{c}\text { FY } \\
1997\end{array}$ & $\begin{array}{c}\text { FY } \\
1998\end{array}$ & $\begin{array}{c}\% \text { CHANGE } \\
85-98\end{array}$ & $\begin{array}{c}\% \text { CHANGE } \\
97-98\end{array}$ \\
\hline USPS & $11,524.2$ & $12,136.2$ & $12,196.2$ & $12,225.0$ & $12,565.3$ & $13,348.6$ & $14,571.2$ & $14,217.1$ & $16,779.2$ & $15,166.8$ & 31.6 & -9.6 \\
\hline DOT & $11,957.0$ & $12,150.8$ & $12,350.7$ & $8,702.6$ & $10,769.7$ & $12,917.0$ & $12,193.7$ & $12,222.9$ & $12,347.9$ & $10,145.0$ & -15.2 & -17.8 \\
\hline DOJ & $2,064.0$ & $2,097.9$ & $2,124.0$ & $3,675.1$ & $2,835.9$ & $3,451.3$ & $3,181.6$ & $3,693.0$ & $3,149.3$ & $7,171.4$ & 247.5 & 127.7 \\
\hline USDA & $4,319.6$ & $4,952.3$ & $5,123.8$ & $4,982.7$ & $4,931.2$ & $5,129.1$ & $4,821.7$ & $4,654.8$ & $3,153.0$ & $3,389.4$ & -21.5 & 7.5 \\
\hline DOl & $3,053.9$ & $3,352.5$ & $3,208.6$ & $3,819.1$ & $3,507.8$ & $3,970.0$ & $2,782.2$ & $1,347.5$ & $2,943.7$ & $2,679.9$ & -12.2 & -9.0 \\
\hline TRSY & $2,155.0$ & $1,473.2$ & $1,655.7$ & $2,065.2$ & $2,420.9$ & $2,161.8$ & $1,773.4$ & $1,350.9$ & $1,561.4$ & $2,078.6$ & -3.5 & 33.1 \\
\hline $\mathrm{DOE}$ & $2,946.7$ & $2,520.4$ & $2,559.7$ & $2,078.1$ & $2,241.3$ & $2,085.9$ & $1,841.9$ & $1,561.0$ & $1,971.0$ & $1,955.6$ & -33.6 & -0.8 \\
\hline NASA & $1,972.7$ & $1,736.7$ & $1,864.0$ & $1,875.4$ & $1,798.0$ & $1,734.9$ & $1,757.0$ & $1,539.3$ & $1,622.1$ & $1,428.3$ & -27.6 & -11.9 \\
\hline VA & 592.8 & 518.3 & 317.4 & 634.9 & 663.9 & 374.4 & 353.6 & 660.7 & $1,199.1$ & $1,380.3$ & 132.9 & 15.1 \\
\hline DOC & $1,010.2$ & $3,100.3$ & $1,315.2$ & 952.5 & 995.7 & 995.2 & 760.6 & 570.1 & 929.1 & 708.4 & -29.9 & -23.7 \\
\hline HHS & 373.3 & 0.0 & 0.0 & 0.0 & 177.3 & 176.3 & 105.5 & 18.6 & 435.0 & 447.7 & 19.9 & 2.9 \\
\hline TVA & 578.5 & 476.6 & 534.7 & 408.8 & 452.4 & 480.3 & 541.7 & 583.8 & 479.5 & 429.1 & -25.8 & -10.5 \\
\hline $\mathrm{DOL}$ & 232.2 & 239.0 & 401.9 & 388.7 & 369.1 & 369.6 & 356.9 & 337.7 & 336.2 & 350.2 & 50.8 & 4.2 \\
\hline GSA & 144.1 & 128.1 & 122.6 & 102.9 & 79.6 & 69.9 & 91.3 & 98.8 & 119.9 & 123.3 & -14.4 & 2.8 \\
\hline EPA & 132.2 & 0.0 & 0.0 & 0.0 & 100.7 & 97.8 & 99.5 & 76.3 & 136.8 & 97.7 & -26.1 & -28.6 \\
\hline ST & 14.8 & 34.9 & 0.0 & 0.0 & 7.5 & 0.0 & 0.0 & 0.0 & 44.7 & 40.9 & $177: 0$ & -8.5 \\
\hline HUD & 0.0 & 0.0 & 32.7 & 33.6 & 31.6 & 30.7 & 25.4 & 25.4 & 28.3 & 23.3 & 0.0 & -17.5 \\
\hline FCC & 12.4 & 9.1 & 7.2 & 7.5 & 7.2 & 6.6 & 6.6 & 4.8 & 7.1 & 6.6 & -46.7 & -6.9 \\
\hline PCC & 530.4 & 653.7 & 578.6 & 699.6 & 684.9 & 688.4 & 866.7 & 829.7 & 766.8 & 0.0 & -100.0 & -100.0 \\
\hline OTHER* & 39.2 & 69.6 & 27.6 & 113.6 & 106.7 & 105.4 & 119.6 & 116.9 & 140.1 & 147.6 & 276.3 & 5.4 \\
\hline \multicolumn{13}{|c|}{ CIVILIAN AGENCIES } \\
\hline TOTAL & $43,653.1$ & $45,649.7$ & $44,420.7$ & $42,765.2$ & $44,746.7$ & $48,193.3$ & $46,250.1$ & $43,909.3$ & $48,150.2$ & $47,770.2$ & 9.4 & -0.8 \\
\hline DOD & $890,679.9$ & $881,345.1$ & $926,033.6$ & $740,357.2$ & $727,887.1$ & $674,597.5$ & $640,893.4$ & $631,202.0$ & $617,235.4$ & $579,959.8$ & -34.9 & -6.0 \\
\hline \multicolumn{13}{|c|}{ ALL AGENCIES } \\
\hline TOTAL & $934,333.0$ & $926,994.8$ & $970,454.3$ & $783,122.4$ & $772,633.7$ & $722,790.8$ & $687,143.4$ & $675,111.3$ & $665,385.6$ & $627,729.9$ & -32.8 & -5.7 \\
\hline MBOE & 160.4 & 159.1 & 166.6 & 134.4 & 132.6 & 124.1 & 118.0 & 115.9 & 114.2 & 107.8 & & \\
\hline Petajoules & 985.7 & 977.9 & $1,023.8$ & 826.2 & 815.1 & 762.5 & 724.9 & 712.2 & 702.0 & 662.2 & & \\
\hline
\end{tabular}

*Other includes for certain years the CFTC, CIA, FEMA, HUD, NSF, NRC, OPM, and USIA.

Note: Sum of components may not equal total due to independent rounding.

Source: Federal Agency Annual Energy Management Data Reports 
FIGURE 10

Defense and Civilian Federal Energy Consumption in

Vehicles and Equipment by Fuel Type, FY 1998

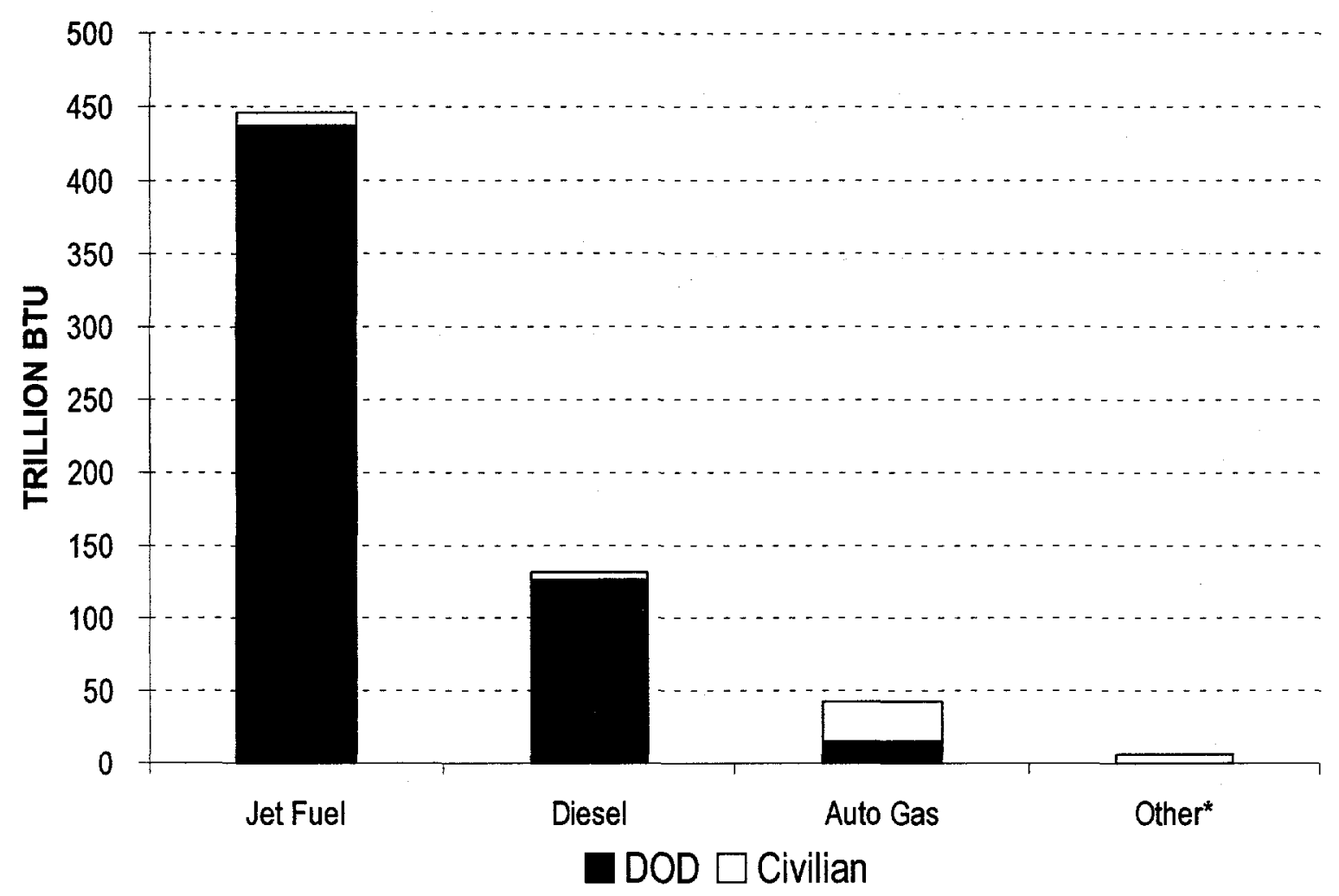

*Other includes navy special, aviation gas, and LPG/propane

Figure 10 depicts the vehicles and equipment fuel mix within DOD and civilian agencies. Jet fuel accounts for 445.5 trillion Btu or 71.0 percent of the total energy usage in the category, with 21.1 percent attributed to diesel and distillate fuel, 6.9 percent to auto gasoline, and 1.1 percent to aviation gasoline, navy special, LPG/propane and other fuels, combined.

As shown in Tables 11-A and 11-B, the Federal Government spent $\$ 4,346.4$ million on vehicles and equipment energy in FY 1998, 6.7 percent more than the FY 1997 expenditure of $\$ 4,073.3$ million constant dollars. In FY 1998, the combined price for all types of vehicles and equipment energy was $\$ 6.92$ per million Btu, up 13.1 percent from FY 1997. The average real cost of gasoline to the Federal Government declined from $\$ 1.06$ per gallon in FY 1997 to $\$ 1.03$ in FY 1998. The unit cost for diesel/distillate fuel increased 8.8 percent while the unit cost for jet fuel rose 14.8 percent.

When compared to FY 1985 using constant 1998 dollars, energy costs for vehicles and equipment decreased 50.0 percent from $\$ 8,700.3$ million to $\$ 4,346.4$ million in FY 1998. During that same period, the Government's combined cost for vehicles and equipment energy, in constant dollars, fell 25.6 percent from $\$ 9.31$ per million Btu to $\$ 6.92$ per million Btu.

Vehicle and equipment fuel costs in FY 1998 represent 51.1 percent of the Government's total energy costs of $\$ 8.3$ billion. 
TABLE 11-A

DEFENSE AND CIVILIAN FEDERAL COSTS FOR VEHICLE AND EQUIPMENT ENERGY IN FY 1998

(In Millions of Dollars)

$\begin{array}{lcrrrrrrr}\text { AUTOGAS } & \begin{array}{c}\text { DIST. } \\ \text { DIESEL }\end{array} & \begin{array}{c}\text { LPG/ } \\ \text { PROPANE }\end{array} & \begin{array}{c}\text { AVIATION } \\ \text { GAS }\end{array} & \text { JET FUEL } & \begin{array}{c}\text { NAVY } \\ \text { SPECIAL }\end{array} & \text { OTHER } & \text { TOTAL } \\ \text { DEFENSE } & 121.041 & 791.847 & 0.612 & 0.011 & 3,050.483 & 0.000 & 1.347 & 3,965.341 \\ \text { CIVILIAN } & 234.744 & 37.750 & 3.241 & 2.959 & 62.532 & 0.000 & 39.838 & 381.064 \\ \text { TOTAL } & 355.785 & 829.597 & 3.853 & 2.970 & 3,113.015 & 0.000 & 41.185 & 4,346.405\end{array}$

AVERAGE COST PER UNIT, BASED ON REPORTS FROM AGENCIES

$\begin{array}{llll}\text { AUTOGAS } & =1.03 / \text { GALLON } \\ \text { DIST/DIESEL } & =0.87 / \text { GALLON } \\ \text { LPG/PROPANE } & =0.94 / \text { GALLON } \\ \text { AVIATION GAS } & =1.77, \text { GALLON } \\ \text { JET FUEL } & =0.91 / \text { GALLON } \\ \text { NAVY SPECIAL } & =0.00 / \text { GALLON } \\ \text { OTHER } & =6.60 / \text { MILLION BTU }\end{array}$

DATA AS OF 01/10/00

Note: Sum of components may not equal total due to independent rounding.

Source: Federal Agency Annual Energy Management Data Reports 
TABLE 11-B

CONSUMPTION AND COSTS OF VEHICLE AND EQUIPMENT

ENERGY BY FUEL TYPE IN FY 1998, FY 1997, AND FY 1985

(Constant 1998 Dollars)

ENERGY TYPE

FY 1998

DIST/DIESEL

LPG/PROPANE

AVIATION GASOLINE

JET FUEL

NAVY SPECIAL

OTHER

TOTAL
AUTO GASOLINE

COST PER
MMBTU

$627,729.9$

AVERAGE COST PER MMBTU $=\$ 6.924$

FY 1997

AUTO GASOLINE

DISTIDIESEL

LPG/PROPANE

AVIATION GASOLINE

JET FUEL

NAWY SPECIAL

OTHER

TOTAL

$39,047.5$

$135,846.0$

18.7

253.7

$475,672.5$

0.0

$14,547.2$

$665,385.6$

AVERAGE COST PER MMBTU $=\$ 6.122$

\section{FY 1985}

AUTO GASOLINE

DIST/DIESEL

LPG/PROPANE

AVIATION GASOLINE

JET FUEL

NAVY SPECIAL

OTHER

$$
\begin{array}{r}
50,481.7 \\
169,217.9 \\
149.3 \\
1,882.3 \\
705,675.5 \\
6,687.7 \\
238.6
\end{array}
$$

TOTAL

$934,333.0$

AVERAGE COST PER MMBTU $=\$ 9.311$
8.2644

6.2699

9.8035

14.1462

6.9874

0.0000

6.5971

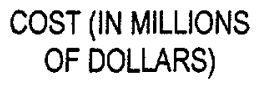

COST (IN MILLIONS

OF DOLLARS)

$$
\begin{array}{r}
355.785 \\
829.597 \\
3.853 \\
2.970 \\
3,113.045 \\
0.000 \\
41.185 \\
4,346.405
\end{array}
$$

$\begin{array}{rr}8.5085 & 332.234 \\ 5.7647 & 783.117 \\ 8.7281 & 0.164 \\ 14.7634 & 3.744 \\ 6.0876 & 2,895.713 \\ 0.0000 & 0.000 \\ 4.0117 & 58.360\end{array}$

$4,073.332$

$\begin{array}{rr}10.8466 & 547.557 \\ 8.6561 & 1,464.773 \\ 10.0607 & 1.502 \\ 16.0230 & 30.159 \\ 9.3539 & 6,600.802 \\ 8.0275 & 53.686 \\ 7.7387 & 1.846 \\ & 8,700.327\end{array}$

DATA AS OF 01/10/00

Note: $\quad$ Sum of components may not equal total due to independent rounding.

Source: $\quad$ Federal Agency Annual Energy Management Data Reports 


\section{B. Alternative Fuel Vehicles}

An alternative fuel vehicle (AFV) can be manufactured as an AFV or converted to an AFV as either a bi-fuel, flexible fuel, or dedicated vehicle. A bi-fuel vehicle has the ability to operate on either an alternative fuel or gasoline, whereas a flexible fuel vehicle has the ability to operate on a mixture of alternative fuel and petroleum-based fuels. Dedicated vehicles are designed to operate only on alternative fuel. The alternative fuels currently used by Federal agencies are: M-85 (85 percent methanol, 15 percent gasoline), E-85 (85 percent ethanol, 15 percent gasoline), CNG (compressed natural gas), LNG (liquefied natural gas), LPG (liquefied petroleum gas), and electricity.

The U.S. Postal Service continues to operate the largest CNG fleet in the country. Since 1989, 7,678 vehicles have been converted to compressed natural gas. Most USPS AFVs are dualfueled (gasoline and CNG). USPS acquired two electric vehicles in FY 1998 in joint efforts with the Department of Energy and under contract with Ford Motor Company and General Motors Corporation-Hughes. USPS engineering staff, in cooperation with other Federal agencies and private industry, continues to evaluate electric and alternative fuel technologies as they become available.

Section 308 of Title III of EPACT, 42 U.S.C. $\S 13217$, requires agencies to measure the aggregate percentage of alternative fuel use in dual-fueled vehicles in their fleets. In an effort to better fulfill this reporting requirement, vehicle fleet managers and representatives from DOE, GSA, and other agencies conducted coordinating meetings during FY 1996 on this issue. These meetings resulted in a revised GSA Agency Report of Motor Vehicle Data (form SF-82) for collecting acquisition, fuel consumption, and fuel cost data for non-tactical motor vehicles. The revised SF-82 was distributed by GSA to agency fleet managers beginning in FY 1997. GSA compiled this data for FY 1998, including alternative fuel consumption data reported under Sections 303 and 308 of EPACT, and forwarded this information to DOE for inclusion in the Annual Report to Congress.

As shown in Table 12, the Federal Government consumed 576.4 billion Btu of alternative fuels in non-tactical vehicles during FY 1998. This is equivalent to 4.6 million gallons of gasoline. Alternative fuel consumption comprises 0.1 percent of the energy used in all Government vehicles and equipment. When compared with Federal consumption of automobile gasoline, alternative fuels comprise 1.3 percent of this energy use. 
TABLE 12

FEDERAL AGENCY CONSUMPTION OF ALTERNATIVE FUELS

IN NON-TACTICAL VEHICLES, FY 1998

(In Billions of Btu)

\begin{tabular}{|c|c|c|c|c|c|c|c|c|}
\hline & CNG & E-85 & Electricity & M-85 & $\begin{array}{c}\text { LPG/ } \\
\text { Propane }\end{array}$ & Biodiesel & Hydrogen & Total \\
\hline USPS & 389.59 & 0.00 & 0.01 & 0.00 & 0.00 & 0.00 & 0.00 & 389.60 \\
\hline DOD & 127.59 & 32.15 & 7.73 & 4.21 & 1.55 & 0.00 & 0.05 & 173.27 \\
\hline DOE & 6.07 & 0.00 & 0.00 & 0.00 & 0.00 & 0.00 & 0.00 & 6.07 \\
\hline USDA & 0.25 & 3.84 & 0.11 & 0.00 & 0.00 & 0.00 & 0.00 & 4.21 \\
\hline Treasury & 0.28 & 0.82 & 0.00 & 0.13 & 0.07 & 0.00 & 0.00 & 1.29 \\
\hline Labor & 0.91 & 0.00 & 0.00 & 0.00 & 0.00 & 0.00 & 0.00 & 0.91 \\
\hline Interior & 0.28 & 0.00 & 0.00 & 0.02 & 0.04 & 0.00 & 0.00 & 0.34 \\
\hline Justice & 0.00 & 0.27 & 0.00 & 0.00 & 0.00 & 0.00 & 0.00 & 0.27 \\
\hline VA & 0.00 & 0.15 & 0.00 & 0.00 & 0.00 & 0.00 & 0.00 & 0.15 \\
\hline DOT & 0.00 & 0.13 & 0.00 & 0.00 & 0.00 & 0.00 & 0.00 & 0.13 \\
\hline EPA & 0.08 & 0.00 & 0.00 & 0.00 & 0.00 & 0.00 & 0.00 & 0.08 \\
\hline SSA & 0.00 & 0.00 & 0.00 & 0.00 & 0.00 & 0.05 & 0.00 & 0.05 \\
\hline NASA & 3.60 & 0.00 & 0.00 & 0.00 & 0.20 & 0.00 & 0.00 & 0.00 \\
\hline TOTAL & 528.65 & 37.37 & 7.86 & 4.36 & 1.86 & 0.05 & 0.05 & 576.39 \\
\hline
\end{tabular}

During FY 1998, compressed natural gas (CNG) comprised the largest portion of alternative fuel consumption with 91.7 percent. An ethanol and gasoline blend (E-85) is the second most consumed alternative fuel with 6.5 percent.

The U.S. Postal Service uses the majority of alternative fuels, consuming 67.6 percent of the total alternative fuel used by the Federal Government. The Postal Service's consumption of 389.6 billion Btu of CNG comprises 2.6 percent of the agency's total vehicle fuel consumption.

The Department of Energy has made efforts to provide the private and public sector with information on issues concerning AFVs. An Alternative Fuels Hotline (1-800-423-1DOE) was established in June 1992 to provide callers from Federal agencies, industry and the public with answers to questions on AFVs. By calling the toll free number, callers can request information on AFVs. In 1998, 9,104 calls were received and 107,358 documents were distributed. Many callers had questions concerning the purchase and conversion to of AFVs, EPACT and Clean Air Act requirements, funding and tax incentives, and training and safety issues.

The Alternative Fuels Data Center (AFDC), which is located at the National Renewable Energy Laboratory (NREL) in Golden, Colorado, may be accessed by the public on the Internet at http://www.afdc.nrel.gov. The site was accessed more than 2.5 million times in 1998, indicating a growing public interest in alternative fuels. The AFDC is the central repository for data from DOE's alternative fuel vehicle demonstration programs. The AFDC stores data on demonstration programs that receive funding support authorized by the AMFA of 1988 . Information collected and provided by the AFDC includes:

- data on 600 government fleet vehicles;

- refueling site information for CNG, LPG, Ethanol, and Methanol; 
- information on emissions, mileage, fuel economy;

- information on emissions, for flexible fuel vehicles running on alcohol fuels and gasoline;

- repair and maintenance logs for alternative fuel fleet vehicles;

- heavy duty and transit bus data on performance, emissions, fuel economy, and mileage;

- data on the Clean Fleet Program - run by Federal Express and South Coast Air Quality Management District (a controlled comparative study of operating data from gasoline vehicles and different types of alterative fuels).

Federal efforts to expand deployment of AFVs were boosted by the Clean Cities Program during FY 1998. The Clean Cities Program, initiated by the DOE in. September 1993, is a voluntary program designed to increase fleet vehicle alternative fuel use by encouraging partnerships between fuel suppliers, vehicle manufacturers, fleet managers, and Federal, State, and local government agencies. DOE supports Clean Cities participants through the placement of Federal vehicles and by maintaining a national hotline and a support staff member at each of its ten regional support offices, which provide local assistance concerning federal and State requirements for $\mathrm{AFV}$ acquisitions and conversions and assist local Clean Cities with their alternative fuels market development. In 1998, 14 new cities were awarded the Clean Cities designation, for a total of 74 Clean Cities. DOE has established a number to handle inquiries from cities interested in joining the program: 1-800-CCITIES. The program's Internet address, www.ccities.doe.gov, was accessed 505,144 times during FY 1998. 


\section{FEDERAL AGENCY ENERGY MANAGEMENT ACTIVITIES}

\section{DEPARTMENT OF AGRICULTURE (USDA)}

Energy Efficiency Performance and

Implementation Strategies

In FY1998, the United States Department of Agriculture reported a decrease of 14.0 percent in Btu per gross square foot compared to FY 1985.

\section{USDA Performance Toward Buildings Energy Reduction Goals}

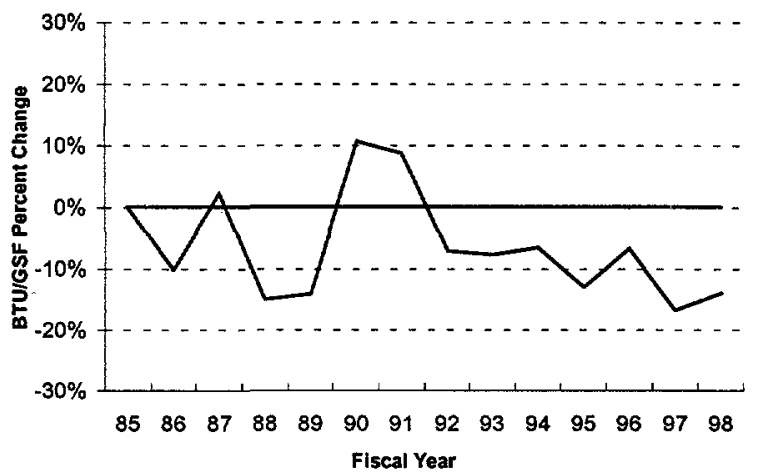

USDA Buildings Energy Use and Costs, FY98

$\begin{array}{lrr} & \text { BBtu } & \text { \$(Thou.) } \\ \text { Electricity } & 1,172.0 & 23,040.6 \\ \text { Fuel Oil } & 63.5 & 468.6 \\ \text { Natural Gas } & 485.3 & 2,064.4 \\ \text { LPG/Propane } & 207.1 & 1,326.4 \\ \text { Coal } & 0.4 & 2.0 \\ \text { Purchased Steam } & 116.0 & 1,153.0 \\ \text { Other } & 66.7 & 1,757.0 \\ & & \\ \text { Total } & 2,111.1 & 29,812.0\end{array}$

During FY 1998, USDA discovered a discrepancy in the methodology used in reporting square footage data for previous years. Square footage for buildings with fully-serviced leases had been erroneously included in USDA totals dating back to FY 1985 . This is space for which USDA neither paid for, nor reported, energy consumption. Square footage data has been adjusted for all previous years to reflect the removal of fullyserviced leased space.

Following are details of individual USDA agencies' energy conservation improvements in FY 1998:
- The Office of Operations (OO) began work on the South Building Modernization Project, which will result in an energy showcase facility of approximately 2 million square feet. In FY 1998, OO expended approximately $\$ 9$ million for energyefficient plumbing, electrical and HVAC systems.

- The Office of Operations, Washington Area Service Center funded energy improvements in the estimated amount of $\$ 30,000$ in FY 1998, including retrofitting lights, repairing steam systems, installing light sensors, and upgrading insulation.

- The Agricultural Research Service (ARS) has developed a 10-year energy retrofit plan. In 1998, energy audits were performed at ARS locations in Houston, Texas; College Station, Texas; and Albany, California. In FY 1998, it is estimated ARS accomplished more than $\$ 1.9$ million worth of building energy conservation and efficiency improvement projects throughout the nation.

- The Forest Service (FS) completed over 50 audits and is implementing projects as funds are available. Energy conservation work totaling at least $\$ 190,000$ was performed across Regions 2,3 , and 10 , and the North East Station, along with an ESPC delivery order in the Pacific North West Region at Corvallis, Oregon. Also, an energy-efficient ground-coupled heat pump system was installed at the Oconee RD Office in Oconee National Forest, Georgia. A similar system has been designed for the Choctaw RD Office in Ouachita National Forest, Oklahoma.

- FS is developing plans to significantly increase its use of cost-effective solar and other renewable sources. During FY 1998, FS implemented over $\$ 190,000$ worth of renewable energy projects throughout Region 3.

\section{Energy Showcase Facilities}

ARS has named the Horticultural Research Laboratory in Fort Pierce, Florida, and the San Joaquin Valley Agricultural Center in Parlier, California as new building showcases. Highlighted technologies include: 
- Energy-wise exterior skin (the combination of vertical and horizontal fins);

- Building automation systems;

- Occupancy sensors in offices;

- Variable volume ventilation systems in laboratories, energy-efficient chillers, variable-speed pumps, and high efficiency boilers; and

- Energy-efficient lighting.

OO's Beltsville Office Facility won an award as a new construction energy showcase facility for four buildings. Technologies included will be passive solar features, low-E windows, building overhangs, photo sensors, and shading using the existing landscape.

\section{Training}

The ARS Beltsville Area Research Center has an increasingly active energy management group. FS often includes energy management issues and short training sessions during the FS National Facilities Workshops and regional meetings. During the November 1998 national workshop in Tucson, Arizona, representatives from two DOE Regional Offices and Johnson Controls opened discussion of ESPC possibilities.

\section{Funding}

Within USDA agencies, funding for energy and water efficiency improvements in buildings are not kept by line item. Energy efficiency improvements are incorporated into all new construction, remodeling, and many maintenance projects.

\section{Energy Savings Performance Contracts}

Two Super ESPC delivery orders are in the process of being awarded for ARS:

- The National Agricultural Library (NAL) in Beltsville, Maryland was selected by DOE as a pilot site for the Mid-Atlantic Regional Super ESPCs. The Regional award was made in March 1999 and the delivery order will follow. Energy improvements at the NAL will include upgrades of the lighting and HVAC systems, and the upgrading or replacement of water chillers.

- The National Animal Disease Center (NADC) in Ames, Iowa was selected as a pilot site for the Midwest Regional Super ESPC. The delivery order is currently being prepared. Proposed energy improvements include the upgrade of lighting and HVAC systems, and the upgrading or replacement of water chillers.

ARS also examined executing an ESPC at Plum Island, New York, for chilled water loops, lighting, wind power generation, and variable frequency drives. This project was discontinued due to projected environmental impacts on the bird population.

FS signed an ESPC delivery order with Honeywell, Inc., in September 1998 for the Corvallis, Oregon Laboratory. Installation of energy conservation measures including lighting retrofits, an energy management and control system, outside air reduction and steam trap modifications has begun, with final inspection scheduled for June 1999. The contract term is 11 years and will result in projected energy savings of $\$ 775,000$ and an operational savings of $\$ 180,000$. Total capital improvement to the facility is $\$ 448,000$. Total annual savings amount to approximately $\$ 85,000$.

\section{Environmental Activities}

Energy conservation will be incorporated as an element, as appropriate, in position descriptions and performance standards of engineers, facility managers and other energy personnel at ARS, OO-WASC, and FS.

USDA agencies participate in the annual Federal Energy and Water Management Awards. Also, ARS is looking into establishing a similar program to recognize ARS Area and Location employees for their contribution to energy conservation.

ARS has incorporated energy efficiency concerns and measures in O\&M contract solicitations and evaluation criteria. WASC has made significant progress in the procurement of environmentally sound energy-efficient products, and has updated the O\&M contract documentation to require the use of energy-efficient LED exit signs and compact fluorescent bulbs.

\section{Energy Management Contact}

\section{Ms. Sonia Torres}

Office of Procurement and Property Management

U.S. Department of Agriculture

Mail Stop 9304

Washington, DC 20250-9304

Phone: 202-720-3673

Fax: 202-720-3747 

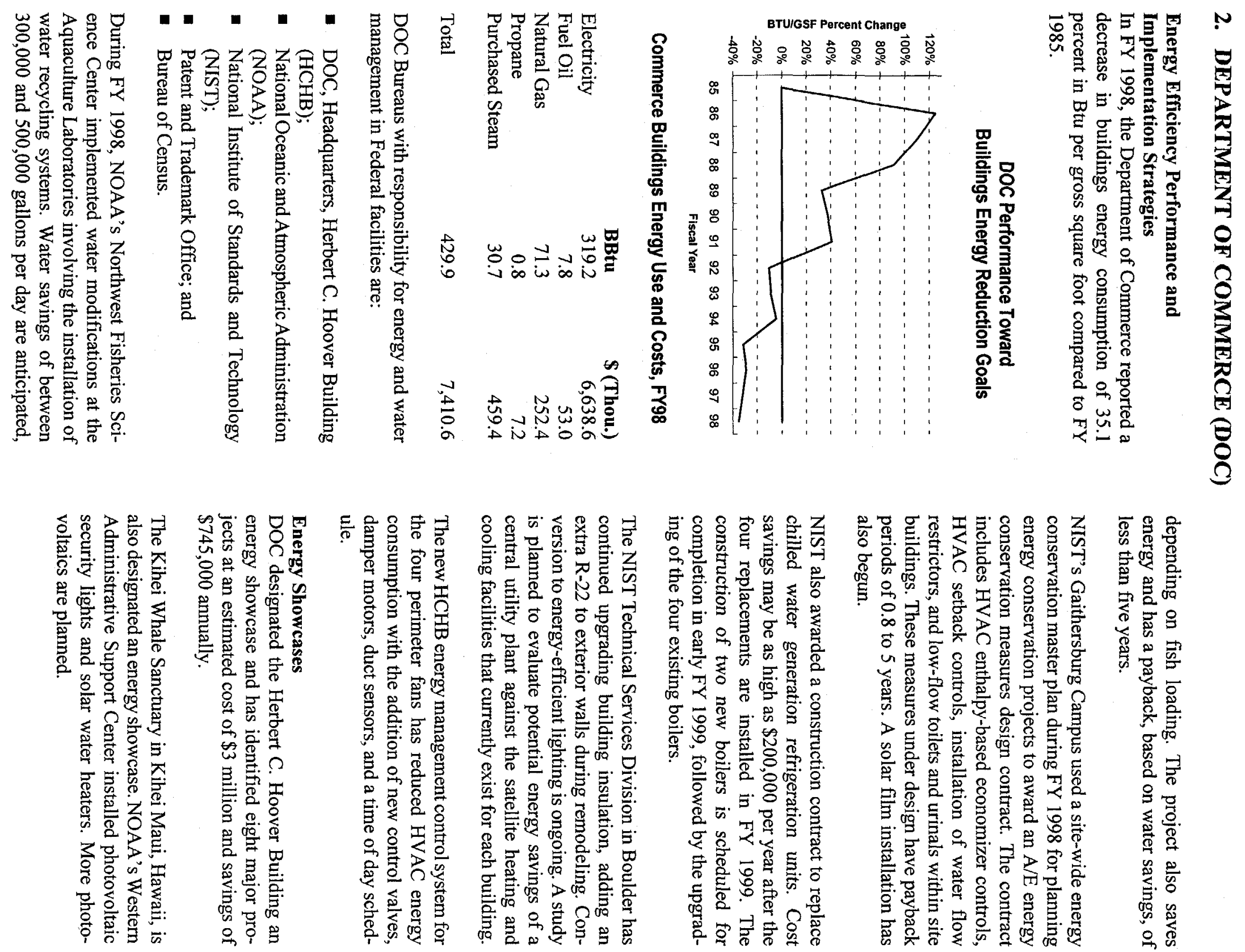


\section{Energy Savings Performance Contracts}

NOAA is considering DOE's Super ESPC to fund solar and fuel cell projects for the National Weather Service Pacific Weather Service Offices and Pacific Tsunami Warning Center in Hawaii. Proposed projects include photovoltaics for total daytime electrical power and fuel cells for nighttime power.

Other proposed NOAA Super ESPC projects include upgrading and replacing $\mathrm{HVAC}$ units and retrofitting fluorescent lighting fixtures.

\section{Utility Partnerships}

DOC is working with GSA and DOE to implement some of the HCHB projects through an energy service agreement with the local utility company, the Potomac Electric Power Company. Using this method, improvements will be completed at no initial cost to the Government.

The Kihei Whale Sanctuary photovoltaic project is being cofunded by DOE's National Renewable Energy Laboratory and the Maui Electric Company.

\section{Environmental Activities}

DOC cosponsored the World Energy and Environmental Congress/Environmental Technology Conference (WEEC/ETE) hosted by the Association of Energy Engineers. More than 5,000 professionals from 48 states and 16 countries participated. DOC selected WEEC/ETE as an official Foreign Buyer Program in support of the export potential of the industry it serves.
DOC is a signatory to the Energy Efficiency and Resource Conservation Challenge, and participates on the Interagency Energy Management Work Group. Through this Work Group, DOC has participated in peer review of product recommendations and distributed buying guides to all DOC facility managers.

DOC received the Corporate Energy Management of the Year Award for 1998 from the Association of Energy Engineers. DOC also received a 1998 Federal Energy and Water Management Award for Small Groups in recognition of the alternative financing techniques used in implementing the energy conservation projects at the HCHB.

\section{Energy Management Contact}

Mr. James Woods

Energy Conservation Officer

Office of Federal Property Programs

U.S. Department of Commerce

Herbert C. Hoover Building, Room 1329

$14^{\text {th }}$ and Constitution Avenue, NW

Washington, DC 20230

Phone: 202-482-0885

Fax: 202-482-1969 


\section{DEPARTMENT OF DEFENSE (DOD)}

\section{Energy Efficiency Performance and Implementation Strategies}

In FY 1998, the Department of Defense reported a decrease in its buildings and facilities energy of 19.1 percent in Btu per gross square foot compared to FY 1985.

\section{DOD Performance Toward Buildings Energy Reduction Goals}

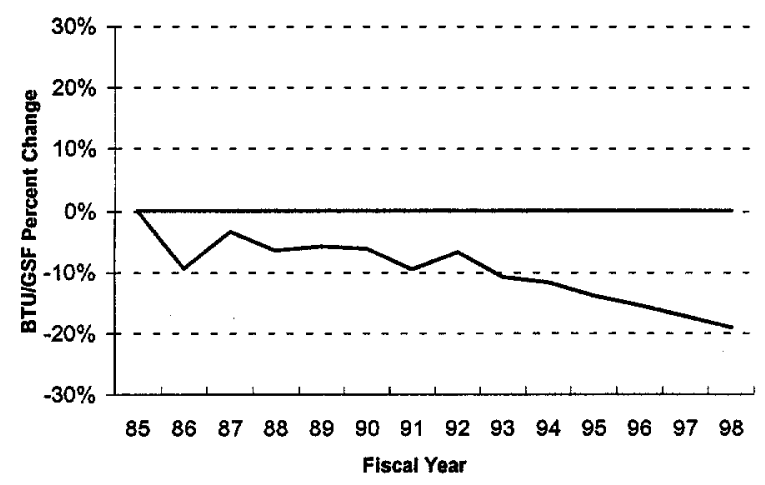

DOD Buildings Energy Use and Costs, FY98

$\begin{array}{lrr} & \text { BBtu } & \text { \$(Thou.) } \\ \text { Electricity } & 84,903.7 & 1,416,213.6 \\ \text { Fuel Oil } & 30,769.4 & 160,998.7 \\ \text { Natural Gas } & 76,429.2 & 296,726.2 \\ \text { Propane } & 1,585.1 & 14,569.0 \\ \text { Coal } & 15,497.2 & 32,942.9 \\ \text { Purchased Steam } & 10,706.5 & 163,328.0 \\ \text { Other } & 676.6 & 732.0 \\ & & \\ \text { Total } & 220,567.6 & 2,085,510.4\end{array}$

DOD's strategy to reduce its energy consumption has two parts: one directed at what is currently owned and the other at what is planned to be built. The strategy for existing structures focuses on using public and private sector capital to finance energy-savings investments through the use of shared savings contracts and areawide agreements with local utilities. The strategy for reducing energy consumption in new buildings relies on taking advantage of new design techniques and energy efficient materials to increase energy efficiency. Specifically:

- Wherever practicable, DOD uses the investment capital of private industry and public utilities to make its current inventory more energy efficient. DOD has multi-regional energy savings perfor- mance contracts (ESPCs)-which cover all fifty states and the District of Columbia - with a combined private sector investment capacity of $\$ 3.2$ billion, available for use by all Military Services and Defense agencies. Additionally, the Components are continuing their pursuit of partnerships and demand-side management (DSM) agreements with public utilities. These alternative financing methods are augmented by a modest amount of appropriated funding ( $\$ 40$ million in FY 1998) to create a balanced program.

- DOD will utilize the principles of "Sustainable Design" in new construction, where it has been determined to produce the lowest life-cycle costs. Sustainable Design methods use the most energy efficient and environmentally sustainable products, optimize architectural design to incorporate local natural conditions, and provide for indoor workplace environmental quality. Demonstration projects undertaken by the Military Departments have shown that this approach to design produces 30 to 50 percent in energy savings with minimal investment.

Confident that it will continue to achieve its goals, DOD understands that significant challenges remain: the demolition and replacement of World War II-era buildings, accomplishment of a significant percentage of fast payback energy savings measures, and changes in the electricity market. Specific observations include:

- New higher-efficiency facilities are often unable to offset the loss of large quantities of space with minimal energy loads, resulting in higher energy density, a trend that may continue in the future as more older facilities are demolished and replaced. In addition, automation of processes tends to produce higher energy usage per square foot.

- There is concern also that electricity restructuring may affect DOD's ability to use private-sector funds to finance energy savings measures. If electric rates decrease substantially, the amount of monetary savings per unit of energy savings will be less, making these arrangements less financially attractive.

Aside from the initiatives for existing or new facilities, the Defense Reform Initiative established the Defense 
Energy Support Center (DESC) in 1998. DESC is becoming involved in all facets of the DOD energy program, potentially making significant contributions to DOD's conservation efforts. DESC has completed a study of the regulatory and utility market situations across the U.S., hosted a DOD Joint Utility Privatization conference, as well as several "industry forums" on utilities, and initiated its first World-Wide Energy Conference to be held in January 1999.

All Components continued their efforts to improve energy conservation through energy awareness training and procurement of cost-effective ENERGY STAR ${ }^{\circledR}$ products and products in the top 25 percent of energy efficiency. The procurement of green power and environmentally-friendly products is also strongly encouraged, where cost effective.

DOD continues making progress in completing audits of all of its facilities and is undertaking energy conservation measures that have a payback period of ten-years or less to the maximum extent possible. The Defense Components used a variety of means to accomplish their audits, including appropriated funds, ESPCs and DSM agreements. Some audits have been combined with existing energy databases, such as the Renewables and Energy Efficiency Planning (REEP) Program, and the FEMP Federal Energy Decision Screening (FEDS) system. Appropriated funding was used to hire Architect/Engineer firms to complete audits and project documentation as a single package, while ESPCs and DSMs were used to conduct audits and then install energy savings measures. The Army's Construction Engineering Research Laboratory (CERL) has worked with some Components to develop computer modeling for both auditing and reducing energy consumption.

\section{Use of Solar and Renewable Energy}

In early 1998, DOD committed itself to the Million Solar Roofs Initiative. DOD predicts that it will have over 3,000 "solar roofs" in use by the end of FY 2000. In addition to these planned projects, DOD expects to develop and implement other solar and solar-thermal projects. The following projects, totaling 1,226 "solar roofs," were implemented in FY 1998:

- Pearl Harbor Complex, HI - 136 units of domestic hot water heating;

- Naval Air Weapons Station, China Lake, CA photovoltaic (PV) module test facility, $2 \mathrm{~kW}$;

- Naval Air Weapons Station, China Lake, CA - 4 PV/Diesel Hybrid power systems, $815 \mathrm{~kW}$;
- Naval Auxiliary Landing Field San Clemente Island, CA - PV/Diesel Hybrid power system, 80 $\mathrm{kW}$;

- Santa Cruz Island, CA - PV/Diesel Hybrid power system, $110 \mathrm{~kW}$;

- Marine Corps Base Twentynine Palms, CA PV/Diesel Hybrid power system, $110 \mathrm{~kW}$; and

- Yuma Proving Ground, Yuma, AZ - Grid connected PV Peak Power Station, $900 \mathrm{~kW}$.

In addition to the Million Solar Roofs Initiative, DOD continues to emphasize the use of solar and other renewable energy sources, where it is cost effective. Passive solar designs, such as building orientation and window placement/sizing, are already being implemented in a variety of building types. The Navy uses the revenue from sales of excess geothermal power at NAWS China Lake, CA, to finance additional energy conservation and technology projects. DOD anticipates more growth in the implementation of renewable energy and active solar technologies due to the recent availability of DOE's technology-specific ESPCs.

The following summary provides a description of additional DOD accomplishments in renewable energy, in addition to those in the Million Solar Roofs Initiative during FY 1998.

- Fort Hood, TX -22 units of solar (PV) parking lot lighting;

- Fort Hood, TX - 70 units of active daylighting systems;

- Naval Air Station Pensacola, FL - retrofitted 70 air source heat pumps with geothermal;

- Naval Auxiliary Landing Field San Clemente Island, $\mathrm{CA}-450 \mathrm{~kW}$ wind farm;

- Kadena AFB, JA - two PV-assisted domestic hot water systems (demo project);

- Hurlburt Field, FL - 100 geothermal heat pumps installed in Military Family Housing (MFH);

- Altus AFB, OK - solar (PV) fuel-depot and airfield lighting;

- Los Angeles AFB, CA - solar (PV) street lighting; and

- Pentagon-Solar Dish/Sterling Engine demonstration project $-25 \mathrm{~kW}$.

\section{Minimization of Petroleum}

Overall, DOD consumption of fuel oil in buildings and facilities decreased by 8.1 percent from FY 1997 to FY 1998. Each Military Component's energy management plan includes a strategy to minimize the use of petroleum. Where cost-effective, heating plants are 
being converted to natural gas. With respect to cooling facilities, however, natural gas cooling is cost-effective only in cases where the existing system has failed and must be replaced. Otherwise, the cost of the equipment overrides the increase in efficiency. The Navy has developed a heating and cooling plant optimization program to maintain central plants at optimum operating efficiency where petroleum fuels are still in use. In addition, they are surveying heating and cooling plants, and distribution systems to identify fuel switching, remote monitoring and control, and rebuilding equipment projects.

The Navy participated in a Congressional demonstration program for natural gas technologies. Ten phosphoric acid fuel cells were installed at various locations and are now powering nearly 6,000 tons of natural gas cooling equipment, natural gas heat pumps, and absorption, desiccant and engine driven chillers. The Air Force is continuing to convert some of their installations to natural gas, especially Aviano AFB, Italy and Columbus AFB, $\mathrm{OH}$, where the economic payback is particularly attractive.

The Defense Energy Support Center serves as the implementing agency for the DOD Direct Supply Natural Gas (DSNG) program. The objective of this program is to obtain the most cost effective supply of natural gas for DOD installations while maintaining supply reliability, thereby encouraging the Components to minimize their reliance on petroleum products. In $\mathrm{FY}$ 1998, 161 installations participated in the DSNG program and achieved more than $\$ 23.6$ million in cost avoidance.

\section{New Space}

During FY 1998, the Sustainable Development and Design process was emphasized in the DOD to ensure new facilities incorporate the most current energy management technology within budgetary constraints. The key points of sustainability include:

- Increased energy conservation and efficiency;

- Increased use of renewable energy resources;

- Reduction or elimination of toxic and harmful substances in facilities and their surrounding environments;

- Improvements to interior and exterior environments leading to increased productivity and better health;

- Efficiency in resource and materials utilization, especially water resources;
- Selection of materials and products based on their life-cycle environmental impacts;

- Increased use of materials and products with recycled content;

- Recycling of construction waste and building materials after demolition;

- Reduction in harmful waste products produced during construction; and

- Facility maintenance and operational practices that reduce or eliminate harmful effects on people and the natural environment.

The Navy has taken a lead role and has implemented the Sustainable Design and Development process for all facility work. Demonstration projects have shown that energy savings of 30 to 50 percent are achievable over conventional design. A "Whole Building" design program is being developed which provides a vast array of technology and tools for each engineer/designer. These tools will be critical for future engineering and design excellence. Productivity gains of 5 to 30 percent are achievable, depending on the existing environment and the proposed new facility.

The Army modified all mechanical guide specifications to include DOE energy efficiency requirements as a part of Sustainable Design. The Army also completed a "greening" of guide specifications to include environmentally preferable products where available.

The Air Force has completed a comprehensive sustainable design manual that all three Military Departments are using. They have also updated their Engineering Technical Letters on new construction to include these concepts.

All Military Departments continue to modify guide specifications to include EPA requirements for recycling and specialized products identified as environmentally preferable. The Navy and several Federal agencies are participating in the Building Product PreApproval Program to develop a listing of products that meet DOD/Federal construction requirements, are environmentally sensitive, and are energy efficient.

\section{Showcase Facilities}

The Military Services have been designating showcase facilities, both in new and existing facilities. The Navy has been particularly proactive by designating two installations (the U.S. Naval Academy, Annapolis, MD, and the Naval Construction Battalion Center, Port Hueneme, CA), rather than individual facilities, as overall showcase activities. In addition, they have designated the Naval Reserve Center at Billings, MT, 
as a showcase for demonstrating energy efficient construction.

At the U.S. Naval Academy in Annapolis, MD, electrical and thermal loads were metered to provide an energy usage map. An energy audit was completed and it identified cost-effective projects in high efficiency motors, compact fluorescent lamps, time clocks, photocells and occupancy sensors. Approximately 18 percent of the Academy's fluorescent lighting were converted to T8 lamps and electronic ballasts. Three chillers were converted to high efficiency chillers. Steam traps are being replaced and a heating system master plan is being developed. Construction was completed to install a natural gas driven $200 \mathrm{~kW}$ fuel cell to generate electricity and hot water. A demonstration natural gas fired heat pump was installed in a military family housing unit. Construction was initiated on a cooling tower and flash tank to save water being dumped into storm drains. Low flow showerheads were installed in athletic facilities and will be installed along with low flow faucets in military family housing. A compressed natural gas (CNG) fueling station was installed and 100 vehicles were converted to CNG. Training for the utilities operations and maintenance staff is continuing to enhance skills that increase the energy efficiency of systems.

The Naval Construction Battalion Center, Port Hueneme, CA, partnered with local utility companies to conduct an energy audit and to design, construct and finance energy conservation projects. This resulted in a base-wide lighting retrofit that replaced fluorescent fixtures with T8 lamps and electronic ballasts. Two solar hot water demonstration units were installed. Five hundred units of family housing have been renovated with energy efficient lighting and appliances. The central steam plant was decentralized in favor of smaller plants with natural gas heating equipment. Over 400,000 square feet of old, inefficient and maintenance intensive facilities were demolished and their functions consolidated into new, efficient facilities. A natural gas driven fuel cell produces $200 \mathrm{~kW}$ of electricity and heats a swimming pool. The base installed a CNG fueling station as well as several electric vehicle charging stations. These support $100 \mathrm{CNG}$ vehicles and 29 electric vehicles.

In addition to the specific installations mentioned above, many advanced energy efficiency technology projects were undertaken throughout DOD. These projects included:
Modifications to Existing Facilities

- Fort Campbell, KY - three barracks - natural gas chillers;

- Fort Hood, TX - 52 units of light emitting diode (LED) traffic signals;

- U.S. Military Academy, West Point, NY - boiler plant - phosphoric acid fuel cell technology;

- Huxtable Pumping Plant, Marianna, AR - Memphis District, Army Corps of Engineers (ACoE) underwater pumps - change to an environmentally-friendly lubricant which also improves pump efficiency;

- Fort Polk, LA - 4,003 family housing units ground-source heat pumps;

- Picatinny Arsenal, NJ - main boiler plant - phosphoric acid fuel cell technology ;

- Picatinny Arsenal, NJ - power plant - steam power generators for peak-load-shedding;

- Hill AFB, UT - aircraft maintenance facility sulfur lighting and HVAC;

- Hill AFB, UT - shipping and receiving facility lighting and HVAC;

- Robins AFB, GA - industrial electronics lab lighting initiatives;

- Hanscom AFB, MA - child care center - lighting and HVAC;

- McClellan AFB, CA - technical training center lighting;

- Kirtland AFB, NM - administrative facility lighting and $H V A C$;

- Los Angeles AFB, CA - administrative facility lighting and HVAC;

- NCBC Port Hueneme, CA-administrative facility - passive and active solar lighting, PV, grey water recovery, and gas-fired heat pump;

- Washington Navy Yard, Washington D.C. headquarters building - sustainable design; and

- Pentagon and Navy Annex, Washington D.C. direct digital controls (HVAC) throughout.

New Facilities

- Marine Corps Base Camp Pendleton, CA - physical fitness center-HVAC and materials selection;

- Marine Corps Logistics Base Albany, GA - child development center - geothermal heat pumps and sustainable design;

- Naval Security Group Activity Sugar Grove, WV - barracks - lighting, HVAC, indoor air quality, and materials selection;

- Naval Air Station New Orleans, LA - physical fitness center - sustainable design, occupancy sensors and indoor air monitoring system; 
- Naval Training Center Great Lakes, $\mathrm{IL}$ - barracks - sustainable design; and

- Barksdale AFB, LA - fitness center - under design for FY 2000 construction.

\section{Procurement of Energy Efficient Products}

DOD has an active program to identify and procure energy efficient products, specifically through the Defense Logistics Agency (DLA). DLA, FEMP, and GSA product catalogs are widely used, as well as the Construction Criteria Base (available on CD-ROM and the Internet). Although no specific procurement targets exists within DOD, purchasing agents are encouraged strongly to procure ENERGY STAR $B$ products and products in the top 25 percent of energy efficiency, when they are cost-effective.

\section{ENERGY STAR@}

The DOD continues to honor its commitment as an ENERGY STAR B Buildings partner with the DOE and EPA, to encourage the use of cost-effective, energyefficient building designs and technologies, and to improve personnel productivity and reduce pollutant emissions. This is reinforced by our strong commitment to sustainable design. The Navy reports that approximately 19 percent of their buildings may be eligible to be ENERGY STARß facilities.

\section{Training}

The DOD believes integrated training and education programs are key factors to increasing energy and water conservation. DOD uses training resources available through the Military Services, DOD of Energy, other Government agencies, and the private sector. Each Component reviews its training requirements, identifies the required training resources, and develops implementation plans to meet requirements.

The Army Corps of Engineers and the Army Logistics Integration Agency provide training to Army energy managers. In FY 1998, the Army trained more than 300 people at a cost of more than $\$ 250,000$. In addition, they produced an Army Energy Program interactive CD and a Web site (http://lia.army.mil). Nearly 400 Navy energy managers received technical training during FY 1998. Personnel attended technical courses offered by universities, associations, and Government agencies. The Navy conducted four sessions of in-house facilities energy management courses in four different Engineering Field Division regions. The courses covered a wide variety of energy-related areas, including Navy policy and instructions, energy data reporting, lighting tech- nology, energy awareness, and project development. The Air Force Institute of Technology (AFIT) Civil Engineering School at Wright-Patterson AFB, Ohio, provides an Energy Management Training course. This course is given twice a year and consists of a one-week (40-hour) course covering the requirements of the Energy Policy Act. AFIT has also incorporated emphasis on energy efficiency in its other technical courses, and serves as the primary source of energy training for the Air Force. More than 400 Defense Commissary Agency (DeCA) employees received commissary specific "Facility Energy Supervisor Training." This 16-hour course is given annually, by region, to train commissary personnel in the basics of refrigeration, HVAC, lighting systems, and management of refrigeration and HVAC maintenance contracts. The remaining Components use existing Service and private sector training resources to meet training requirements.

All of the Services and many of the Defense agencies have implemented extensive public relations campaigns. These include recognizing non-energy individuals for conservation efforts, producing stickers for light switches, publishing "how-to" and "point of contact" manuals, and supporting energy poster contests.

\section{Energy Savings Performance Contracts}

As mentioned above, DOD continues to emphasize the use of alternative funding sources such as ESPCs, DSM agreements and utility partnerships.

The Components either awarded individual ESPCs, or used one of the existing indefinite delivery contracts, such as the Army's multi-regional ESPCs, the Air Force's regional ESPCs, or DOE's Super ESPCswith the trend moving from base-level to regional ESPCs. The Services have designated various agencies to manage their ESPC programs. The Navy managers are located at the Naval Facilities Engineering Service Center at Port Hueneme, California. The Army uses a decentralized approach with the Huntsville (Alabama) Engineering and Support Center providing support, on a reimbursable basis, to installations and Major Commands (MACOMs), who make the decisions on the details of implementing the contracts. The Air Force uses a two tier operation. Tier One is the technical expertise, program management, and policy development at Headquarters Air Force level, utilizing the Air Force Civil Engineer Support Agency (AFCESA). Tier Two is the actual implementation, at the installation level. To validate energy savings, the DOD uses either the North American Measurement and Verification 
(M\&V)Protocol published by DOE/FEMP, or includes specific requirements in the individual contract. These methods may involve computer simulation, metering, engineering calculations, and/or audits.

In FY 1998, six more regional EPSCs were awarded, including coverage of the Caribbean and Guam. There were 18 other separate ESPCs awarded and four delivery orders issued. The anticipated annual savings from the awarded contracts and delivery orders is $\$ 8$ million and 295 trillion Btu.

Normally, cost savings are used to first pay the contractor and then offset other base operating support expenses. In some cases, however, installations decided to seek a shorter contract term and defer all Government cost savings until contract completion.

DOD is working to overcome a lack of knowledge at the user level in order to further increase the use of ESPCs. As the number of success stories has grown-highlighting the capabilities and advantages of ESPCs-more installations have been willing to try this alternative to achieve energy goals. In addition to a lack of knowledge, the perceived complexity of the contracts has caused a reluctance to use them, particularly by installations that are using DSM agreements extensively. The Services have developed training and education programs to overcome these shortfalls.

In addition to increased usage of ESPCs, the Services have continued to use utility partnerships and DSM agreements as a means to achieve the conservation goals. The Navy has been particularly aggressive with DSMs and utility partnerships, and has over 90 contracts in place. The Navy's utility partnership in the San Diego region was selected for recognition in the National Performance Review last year. The Department of the Navy has also entered into partnerships with 22 other utilities. The Air Force has been promoting DSMs as well, awarding six DSM task orders this fiscal year, which are estimated to save more than 600 billion Btu per year.

\section{Vehicles}

In FY 1998, DOD acquired 2,236 AFVs. In addition, DOD received 29 extra AFV credits for acquiring medium- and heavy-duty AFVs, for a total of 2,265 AFVs and credits. The actual total of 2,265 AFVs and credits for FY 1998 represent an increase of 29 percent more the FY 1998 projected total of 1,749 AFVs and credits included in last year's DOD report.
DOD is taking a number of steps in the areas of policy, management and oversight, and budget to achieve compliance with the requirements of Executive Order 13031, "Federal Alternative Fueled Vehicle Leadership." Specific details of the plan are included with the required reporting data. While some obstacles, such as availability of suitable AFV models and availability of adequate alternative fuel infrastructure, remain a significant challenge, DOD is making steady progress toward meeting the requirements of Executive Order 13031.

\section{Environmental Benefits of Energy Management Activities}

DOD recognizes that conserving energy will not only save money, but will also result in substantial environmental benefits. Energy conservation helps DOD meet its requirements under environmental laws, such as the Clean Air Act, by reducing emission of air pollutants, such as ozone and carbon monoxide. In addition, energy conservation helps reduce greenhouse gases, such as carbon dioxide. Therefore, DOD closely coordinates its energy management and environmental programs to take full advantage of their synergy. As a result, DOD has been very successful in reducing its greenhouse gas emissions. From FY 1997 to FY 1998, DOD installations reduced their carbon emissions by 1.6 percent. As active participants in the ENERGY STAR@ Buildings program, leaders in green power use and strong advocates of sustainable design and development, DOD intends to continue this trend into the future.

\section{Energy Management Contact}

Captain Kevin E. Mikula, P.E.

Director, Energy Office

Housing and Energy Directorate

Office of the Deputy Under Secretary of Defense

for Installations

3010 Defense Pentagon, Room 3D-784

Washington, DC 20301-3010

Phone: 703-697-6195

Fax: 703-695-1493 


\section{DEPARTMENT OF ENERGY (DOE)}

Energy Efficiency Performance and

Implementation Strategies

In FY 1998, the Department of Energy reported a decrease in buildings energy consumption of 36.5 percent in Btu per gross square foot compared to FY 1985.

\section{DOE Performance Toward Buildings Energy Reduction Goals}

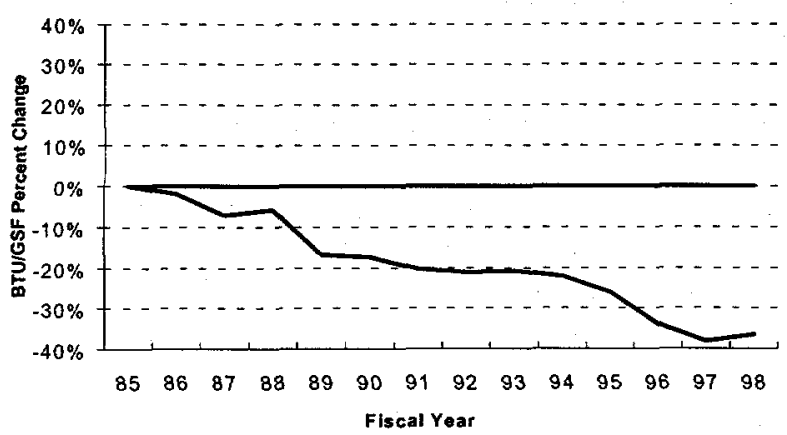

Energy Buildings Energy Use and Costs, FY98

$\begin{array}{lrr} & \text { BBtu } & \text { \$(Thou.) } \\ \text { Electricity } & 10,537.8 & 138,331.8 \\ \text { Fuel Oil } & 1,124.5 & 3,029.5 \\ \text { Natural Gas } & 6,508.4 & 21,546.9 \\ \text { Propane } & 50.0 & 330.1 \\ \text { Coal } & 3,397.6 & 5,196.0 \\ \text { Purchased Steam } & 1,449.7 & 12,141.6 \\ \text { Other } & 58.7 & 909.3 \\ & & \\ \text { Total } & 23,126.7 & 181,485.0\end{array}$

In FY 1998, the United States Department of Energy (DOE) estimates its energy consumption per gross square foot in buildings will decrease by more than 35 percent compared to FY 1985. This reduction is partially due to reduced mission-related activities and overall downsizing of operations and facilities. As manpower is reduced and facilities are closed, efforts are ongoing to consolidate operations and minimize energy use in vacated buildings. This includes review of heating, ventilating, and air conditioning (HVAC) systems; lighting; transformers; and other building equipment usage.

In FY 1998, the Department's Energy Management Team assisted the efforts of the Energy Management
Steering Committee (EMSC) to reduce energy costs by integrating all energy management activities into DOE program operations. The EMSC is comprised of Federal Energy Management Program and DOE Secretarial Officer representatives. It establishes and implements internal policy for energy management, and integrates these activities into DOE program operations. During FY 1998, the EMSC solicited input for identifying missed opportunities in energy efficiency. From these suggestions, four were selected for the Committee's concentration:

- Expand energy management activities to include DOE surplus facilities;

- Integrate chiller replacement with other energy conservation measures;

- Build energy-efficient procurement into DOE operations; and

- Transfer emerging energy efficiency and fossil energy technologies into DOE operations.

DOE field elements continued implementing energy management performance agreements, which more clearly define energy management performance expectations for achieving cost savings. During FY 1998, the eight DOE operations offices, accounting for almost 80 percent of DOE's annual energy costs, delivered SelfAssessment Reports on their progress toward their agreements. The agreements include conducting sitewide comprehensive facility audits. In FY 1998, sitewide comprehensive facility audits were completed at a number of DOE sites. The audits identified projects that will be funded through private sector financing using energy savings performance contracting or utility incentives. Implementation of these performance agreements will continue.

Many DOE sites have implemented a number of ongoing energy-saving measures resulting from previously funded comprehensive audits such as installing energy monitoring and control systems, replacing mercury vapor lamps with higher efficiency metal halide lamps, replacing old fluorescent lamps and ballasts with high-efficiency lamps and electronic ballasts, installing automatic on-off control systems for lighting, installing and replacing building satellite boilers, and 'maintaining and upgrading HVAC equipment and systems to optimize performance. 
Operations and maintenance procedures are utilized to increase energy efficiency at DOE through efficient operation of buildings, improved preventive maintenance, and improved personnel energy training. Specific operations and maintenance efficiency measures include:

- Using pre-engineered operating schedules to optimize chiller plant operations;

- Window replacement and space renovation;

- Thermograph techniques to locate "hot spots" in energy systems;

- Recalibrating thermostats and humidstats, cleaning coils and louvers, and replacing drip pans;

- Setback and shutdown of laboratory fumehood exhaust systems;

- Using well-managed direct digital control (DDC) systems to monitor and control HVAC equipment;

- A steam-trap inspection and replacement program;

- Annual boiler tune-up procedures;

- Inspection procedures for ensuring proper operation of controls on energy-using equipment;

- Recording hourly performance data for boilers and chiller plants, adjusting for peak performance; and

- Reviewing building modification plans for energyuse features (i.e., lighting, ventilation, heating, insulation, etc.).

Examples of operational and energy efficiency projects accomplished in FY 1998 include:

- The Savannah River Operations Office replaced an oversized compressor used for continuous air monitoring with smaller portable units to reduce electrical consumption by half. Outside lighting was turned off during the day at the Consolidated Incineration Facility (CIF). The potential cost savings of using a dedicated load steam generator for meeting CIF production requirements versus the current practice of utilizing D-Area steam produced by South Carolina Electric and Gas are currently being evaluated. Thermostats in two storage trailers were replaced. Energy savings of $\$ 114,000$ were identified. Also, an additional $\$ 57,000$ in utility savings were achieved by the shutdown of an old test reactor facility that was being used as office space.

- The Albuquerque Operations Office completed a number of HVAC and lighting retrofits at the Waste Isolation Pilot Plant (WIPP). The Kansas City Plant (KCP) accomplished several energy conservation activities, including upgrading boilers, installing DDCs, replacing CFC chillers with 134a freon chillers, and installing new steam traps. KCP's plate/frame heat exchanger project is expected to be complete and operational for free cooling during the 1998-99 winter. The Pantex Plant installed photocells on outside lighting, identified and repaired leaking water lines, tuned boilers, right-sized a new air compressor (saving more than $\$ 36,000$ per year), installed new steam traps, installed variable-frequency drives, repaired natural gas line leaks, and right-sized chilled water pumps. Pantex also has a water conservation project under construction that will replace domestic water chlorine injection at the sewer plant with sewer water chlorine injection, saving more than 15 million gallons of water per year.

- The Los Alamos National Laboratory (LANL) completed a site-wide energy conservation program that, if implemented during the next 10 years, could save $\$ 4.3$ million annually. Five buildings and four transportable offices were audited. LANL installed 64 infrared occupancy sensors in offices, conference rooms, and hallways in six buildings.

- Argonne National Laboratory-East (ANL) completed a lighting study. The 200 Area Heat Recovery Study was also completed. ANL was awarded 25 percent ( $\$ 1.1$ million) of the available DOE InHouse Energy Management funds for three projects: electrical DSM for APS $(\$ 370,000$, with a 3.4-year payback), implementing heat recovery in 200 Area Buildings ( $\$ 500,000$, with a 3.4-year payback), and improving raw water distribution $(\$ 260,000$, with a 4.4 -year payback).

- The Princeton Plasma Physics Laboratory completed a lighting retrofit study, installing approximately 900 ultrasonic room occupancy sensors, and upgrading the energy management and control system (now a building automation system). A 
site-wide energy survey is scheduled for completion during FY 1999. Funding has been approved for exit sign retrofits $(\$ 18,700)$ and a lighting retrofit $(\$ 195,000)$.

- The Rocky Flats Environmental Technology Site (RFETS) performed a SAVEnergy audit of 12 buildings along with an energy consumption analysis of 69 other typical buildings, installed two package boilers to improve steam feed efficiency, and reduced exterior lighting at the east and west entry gates.

- Idaho National Engineering and Environmental Laboratory (INEEL) performed facility audits that developed 274 conservation opportunities. If implemented, these would save more than $\$ 51,000$ annually. An excess buildings study was completed, finding that actions completed to date are saving $\$ 269,200$ per year. During the next five years, an additional $\$ 149,200$ will be saved as eight other buildings are removed from service. Total savings are estimated to be $\$ 420,000$ annually. INEEL also installed occupancy sensors, setback thermostats, and LED exit lamps.

- Bonneville Power Administration (BPA) invested $\$ 400,000$ in two air conditioning retrofit projects at the Celilo Convertor Station in The Dalles, Oregon. Two HVAC retrofits are forecast for FY 1999. For the next 10 years, BPA is budgeting $\$ 250,000$ per year to update substation HVAC systems. BPA also retrofitted the mechanical system at the Celilo DC Convertor Station with a heat exchanger. As a result, a 350-ton chiller could be shut down during the winter. At the Kalispell, Montana, maintenance facility, BPA is installing gas radiant heaters in the garages, reducing the energy bill by 30 percent, or $\$ 2,500$, per month.

- The Ohio Field Office's Fernald Environmental Management Project switched to a smaller cooling tower, decreasing the cooling water loop length and reducing pumping energy. The site plans an assessment of its compressed air system in FY 1999.

- Sandia National Laboratory improved their energy management and control system with a more demand-based control strategy, reducing run time of fans and pumps, and reducing simultaneous heating and cooling. One building was completely retrofitted, changing 6,000 lamps from T-12 to T-8 and eliminating more than 1,000 ballasts. Annual savings are conservatively estimated at 250,000 kilowatt-hours, with simple payback in less than 3 years. Twelve remote area buildings were converted from propane to natural gas-fired boilers, saving approximately $\$ 70,000$ a year. Also, a 1million-gallon chilled water storage tank, rated for 10,000 ton-hours of chilled water capacity, was constructed. When this is integrated with the existing chilled water plant, annual savings of around $\$ 150,000$ are expected.

- Pacific Northwest National Laboratory improved energy-related operations and maintenance in the William R. Wiley Environmental Molecular Sciences Laboratory. Early results indicate annual savings in the $\$ 100,000$ range.

- The Richland Operations Office upgraded the lighting system at the Fuels and Materials Examination Facility. At the Plutonium Finishing Plant, 900 standard fluorescent light fixtures were replaced with T-8s and electronic ballasts, and fan motors were upgraded. Numerous general-purpose facilities also had $\mathrm{T}-12$ fixtures $(7,550$ in all) replaced with T-8s saving more than 140,000 kilowatt-hours and \$3,533 annually. Also during FY 1998, 13 transformers were removed and 7 were exchanged, reducing energy consumption and costs by more than 325,000 kilowatt-hours and $\$ 7,800$.

- The Nevada Operations Office installed energyefficient lighting in the Remote Sensing Laboratory. This project included replacing magnetic ballasts and T-12 lamps with energy-efficient electronic ballasts and T-8 lamps with reflectors. Total estimated annual savings are $\$ 52,500$.

- The Lawrence Livermore National Laboratory completed nine energy conservation projects. The projects consist of DDC system installations, lighting retrofits, occupancy sensor installations, and HVAC upgrades. Total construction cost was $\$ 1.36$ million, with cumulative payback in 3.3 years.

- Brookhaven National Laboratory (BNL) received funding of more than $\$ 970,000$ for five new projects. These were an energy management and control system optimization, insulation of steam 
stations and manholes, an exit sign LED retrofit, installation of a side-stream filter for the Central Chilled Water Facility's refrigeration machines, and HVAC balancing. BNL also completed a prioritization survey, which included 99 buildings and 1.7 million square feet. Water consumption was reduced by more than 20 percent $(214.5$ million gallons) with an associated cost savings of $\$ 150,000$.

- Examples of operational and energy efficiency projects completed at the Bettis Atomic Power Laboratory include roof repairs and insulation, occupancy sensor installations, central heating plant improvements, improvements to the energy management system for building HVAC controls, installation of an efficient vacuum pump system, and the installation of efficient heaters on the Corrosion Laboratory Autoclaves. An energy savings of 14.5 billion Btu was achieved.

- The Oak Ridge Operations Office completed several projects. The Oak Ridge Institute for Science and Education (ORISE) replaced an inefficient electric HVAC system with a digitally controlled system with natural gas heating, and completed a multi-site energy audit, an energy conservation baseline study, a HVAC system study, and a lighting system upgrade. ORISE also completed a multi-phase retrofit construction project at the site's $2714 \mathrm{FG}$ Building, which included installing dual glazed windows, attic insulation, and T-8 fluorescent fixtures and electronic ballasts.

- The Federal Energy Technology Center (FETC) completed a preliminary energy audit for both its Pittsburgh, Pennsylvania, and its Morgantown, West Virginia sites. FETC also received $\$ 8,100$ from DOE's Energy Efficiency and Renewable Energy Office to complete a lighting retrofit at FETC's day care facility.

- The Federal Energy Regulatory Commission (FERC) has significantly reduced its energy consumption. All incandescent lights in common areas and department head offices were retrofitted with compact fluorescent bulbs, saving 79,120 kilowatt-hours and more than $\$ 6,300$ per year, and removing 48 recessed incandescent lights in 16 locations, saving 11,232 kilowatt-hours and nearly $\$ 900$ annually. Variable speed drives were in- stalled on fans and water pumps, saving at least 123,000 kilowatt-hours annually.

- Lawrence Berkeley National Laboratory (LBNL) completed eight energy efficiency retrofits. These measures included lighting retrofits, installing variable frequency drives, variable speed drives, boiler retrofits, HVAC replacements, cooling tower efficiency improvements, and installing lighting controls. Spending totaled $\$ 1,449,000$, with estimated annual savings of $\$ 154,000$. The annual energy savings of nearly 3,000 megawatthours will avoid emissions of 725 tons of carbon dioxide, 1.8 tons of nitrogen oxides, and 0.6 tons of sulfur dioxide.

- The Y-12 Plant proposed installing a System Efficiency and Reliability Improvement (SERI) monitoring system at Chiller Building 9767-3 for FY 1998. Annual savings are estimated at $\$ 25,000$.

\section{Energy Showcases \\ The Nevada Operations Office designated the Nevada Support Facility, the C-1 Building Complex in North Las Vegas, the Mercury Cafeteria, and the NTS Badge Office as energy showcases. Installed technologies include high-efficiency lighting, daylighting, xeri- scaping, and energy management and control systems.}

\section{Energy Savings Performance Contracts}

Obtaining alternate financing for energy efficiency projects is vital to continued energy cost reductions. DOE has awarded five site-specific ESPCs to date and is working on several other projects:

- Savannah Operations Office awarded an ESPC to CES/Way International on March 2, 1998. The preliminary proposal for the first task order includes lighting retrofits, redistribution of HVAC loads to the more efficient central chilled water loop, variable frequency drives, installation of smaller motors in some air handling units, and incorporation of energy management systems. The draft cost estimate is about $\$ 1.8$ million, with first year savings of $\$ 291,648$. Final review and acceptance of this proposal is anticipated during the second quarter of FY 1999. The decision has been made to pursue development of energy projects via ESPCs. To this end, $\$ 786,000$ to develop and implement projects was returned to DOE Headquarters. Other than $\$ 90,000$ of previously funded 
capital, all other site energy projects have been completed and closed. These funds, along with approximately $\$ 180,000$ of outstanding cost funds, will be used to support ESPC efforts.

- The Richland Operations Office's Hanford Site awarded an ESPC in FY 1997 with a contract term of 25 years. The 200 East and 300 Area steam plants were closed and replaced with 42 state-ofthe-art package boilers. The new boilers eliminate steam and condensate ground discharges due to the use of a closed loop system, and reduce energy consumption by 30 percent. More than $\$ 108$ million in energy and related operations and maintenance expenses will be saved over 25 years.

- Lawrence Livermore National Laboratory (LLNL) signed a Master Task Agreement (MTA) with two energy savings contractors to perform ESP contractor tasks at the laboratory.

- The Headquarters Forrestal Building had an ESPC to perform a building-wide fluorescent lighting retrofit project that was signed in FY 1993. The annual savings amounts to approximately $\$ 400,000$ and more than 6 million kilowatt-hours. This ESPC is for 7 years. DOE's share of the savings for the first 3 years was approximately $\$ 109,881$ and increased to $\$ 345,922$ in the remaining 4 years of the contract.

- Several ESPC efforts at the Albuquerque Operations Office. The Waste Isolation Pilot Project initiated work to utilize DOE's regional Super ESPC. The initial Request for Proposal (RFP) targets the main chillers, variable-frequency drives for the main underground ventilation fans, DDCs for monitoring and control, and several lighting projects. Estimated investment is $\$ 2$ million, with a 10- to 11-year payback. KCP provided technical support for the regional Super ESPC. The technical portion of the KCP delivery order was completed. The Pantex Plant originally planned a project which included a minimum of 13 energy conservation measures, resulting in annual energy savings of $\$ 645,850$, with a simple payback of less than 8 years. This project was subsequently developed and released as a sole source RFP to NORESCO under the regional Super ESPC program. Two million square feet of plant floor space will be audited. Utility incentives of more than $\$ 2.6$ million over the project's life will remain available. Additional delivery orders will be issued under the Super ESPC.

- LANL entered into an agreement with its Support Services Subcontractor (SSS) whereby the SSS would perform ESPC tasks at LANL. One chiller replacement is at the approval stage for construction, one lighting and HVAC upgrade is at the energy audit stage, and a steam plant and another lighting retrofit are at the proposal stage. The replacement of an old centralized steam plant with 14 satellite boilers is now producing annual savings in excess of the guaranteed \$2.3 million per year.

- INEEL began working on a delivery order for the Western region Super ESPC. This initial delivery order will include lighting and transformers.

- The Nevada Operations Office has an ESPC study near completion, which proposes to use efficient technologies in lighting, HVAC, energy management and control systems, and window treatments. A solicitation package is being processed and will be ready in FY 1999. This package includes an audit of 300,000 square feet of building space.

- Oak Ridge National Laboratory engaged an energy services company (ESCO) through the Southeast region Super ESPC. A notice of intent has been issued for a delivery order covering four buildings, including projects involving lighting, chillers, variable frequency drives, and water fixtures. Delivery order negotiations and award are expected in early FY 1999. Other Oak Ridge Operations Office sites will contact ESCOs through the Southeast region Super ESPC in FY 1999.

- FETC completed a preliminary energy audit for both its Pittsburgh and Morgantown sites and has prepared a technical data package. FETC's goal is to award an ESPC using the Mid-Atlantic region Super ESPC.

\section{Utility Partnerships}

DOE sites continue to participate in and provide utility company incentives and demand side management programs. Examples include:

- ANL developed an agreement with Commonwealth Edison to provide energy conservation projects under their utility incentive program 
initiative. The first delivery order was a pump motor replacement, valued at approximately $\$ 180,000$. ANL also continued its participation in Commonwealth Edison's demand-side reduction program, receiving more than $\$ 450,000$ in demand reduction compensation. Savings for 1998 are expected to be around $\$ 100,000$. ANL also negotiated a reduced rate from the local gas utility.

- The Site Utilities Department of the Savannah River Operations Office entered into negotiations with South Carolina Electric and Gas to modify its existing utility contract to incorporate real-time pricing. This proposal is a 1-year pilot program that will go into effect in December 1998.

- Expected to begin in FY 1998 was a 2-year contract to supply natural gas to the Pittsburgh Naval Reactors Office's Bettis Site. Savings of $\$ 193,000$ were expected.

- Pumps at the Strategic Petroleum Reserve's (SPR) Raw Water Intake Structure (RWIS) were increased in size, warranting an increase in the size of Entergy-owned transformers providing power to the RWIS. SPR negotiated an agreement with Entergy to off-set the cost of construction with actual power usage from the site, saving about $\$ 200,000$ during the contract period. Three field sites, Bayou Choctaw, Big Hill, and both West Hackberry substations use Entergy's time of use rate for annual savings of approximately $\$ 350,000$. Also, the Bryan Mound site is using an interruptible service rate from Houston Lighting and Power.

- BNL initiated negotiations with the New York Power Authority (NYPA). A modified contract is expected in early FY 1999, with the changes estimated to provide over $\$ 2$ million in additional savings. FY 1998 was the first full year of natural gas use at BNL. To date, this has saved BNL more than $\$ 190,000$ in fuel costs compared to the cost of the previously used fuel oil.

- LBNL equalized its electrical energy rates with LLNL's rates, which have been historically lower, through the 3-Lab (LBNL, LLNL, and the Stanford Linear Accelerator Center) Rebilling System. This will save LBNL an estimated $\$ 800,000$ per year.
- The Richland Operations Office began implementing its comprehensive energy management plan and entered into a utility agreement with the Bonneville Power Administration for energy management services.

\section{Vehicles}

DOE has an ongoing program to improve vehicle efficiency, including acquiring alternative-fueled vehicles, downsizing vehicles when appropriate, upgrading preventive maintenance programs, improving maintenance techniques, expanding waste minimization programs, implementing driver awareness training, and providing employee outreach.

In FY 1998, DOE acquired 225 alternative fuel vehicles with most being compressed natural gas (CNG) bifuel vehicles. Several flex-fueled ethanol vehicles were also acquired. Additional AFV acquisitions are planned by FY 1999.

Most DOE sites have an ongoing employee commuter program. These programs promote using ridesharing and mass transit services, as applicable at each site. A transportation coordinator at each site promotes these efforts, as appropriate.

DOE has been turning over more of its fleet operations to GSA to take advantage of their vehicle programs. This provides the benefit of having an ever more efficient, and less costly to maintain, vehicle fleet.

\section{Environmental Benefits}

During FY 1998, DOE continued to focus on reducing chlorofluorocarbons (CFCs) by replacing CFC chillers with new higher efficiency, non-CFC chillers and refrigerant recovery programs. Other measures include fluorescent lamp recycling, procuring recycled goods and products such as printer/copier toner cartridges and paper products, reducing power plant emissions in California, and reducing automobile emissions through the use of compressed natural gas at many DOE sites. Soy-based inks, which are environmentally friendly, are used in some DOE print plants. Site-wide recycling of aluminum beverage cans, batteries, cardboard, paper products, and fluorescent lamps occurs at many DOE sites. Exarnples include:

- ANL found an outlet for recycling fly ash produced at the ANL steam plant. More than 700 metric tons per year is being converted into a byproduct, saving $\$ 40,000$ to $\$ 80,000$ per year. 
- The Savannah River Operations Office replaced four 450-ton chillers in the site's Tritium Area. Also replaced were two 350-ton chillers in the $\mathrm{H}$ Area Canyon facility and one 100-ton chiller in a $\mathrm{H}$-Area Canyon support building.

- The environmental benefits achieved by emission reductions at the on-site steam plants and the offsite power plants are continuous goals of the Savannah River Operations Office site energy management program. The Alternative Fuel Program is an innovative recycling program that targets the waste management needs of regional industry and the fuel needs of the site. Several trial burns of a residual short fiber and coal mixture were conducted during FY 1997, with favorable results. This program will be beneficial to the environment, reduce industry production costs, decrease costs associated with coal consumption, and provide new jobs.

- Supply contracting is conducted at the SPR to minimize biohazards. For example, aerosol spray painting has been banned. Environmental programming eliminated the use of SPR-owned equipment containing polycholrinatedbiphenyls (PCBs). Also, the SPR has completed an inventory of all utilityowned electrical equipment for PCB content. The amount of PCBs involved was documented, and plans have been developed to assure the PCBs are not introduced into the environment.
- Oak Ridge National Laboratory replaced four chillers totaling 1,746 tons of rated capacity with more efficient, non-CFC chillers. The new chillers save approximately 20 percent in chiller energy. Four additional chillers will be replaced in FY 199 and FY 2003.

\section{Energy Management Contact}

Mr. Victor Petrolati, EE-91

DOE Energy Management Team Leader

Federal Energy Management Program

Office of the Assistant Secretary for Energy Efficiency and Renewable Energy

U.S. Department of Energy

1000 Independence Avenue, SW

Washington, DC 20585-0121

Phone: 202-586-4549

Fax: 202-586-3000 


\section{DEPARTMENT OF HEALTH AND HUMAN SERVICES (HHS)}

\section{Energy Efficiency Performance and Implementation Strategies}

The Department of Health and Human Services reported a 1.8 percent increase in buildings consumption in Btu per gross square foot in FY 1998 when compared to the adjusted FY 1985 baseline. The adjusted baseline decreased the agency's FY 1985 baseline by 11 percent which in turn reflected a decrease in the agency's performance to the mandated reductions, despite the positive achievement of an 8 percent reduction in Btu/GSF from FY 1997 to FY 1998.

\section{HHS Performance Toward Buildings Energy Reduction Goals}

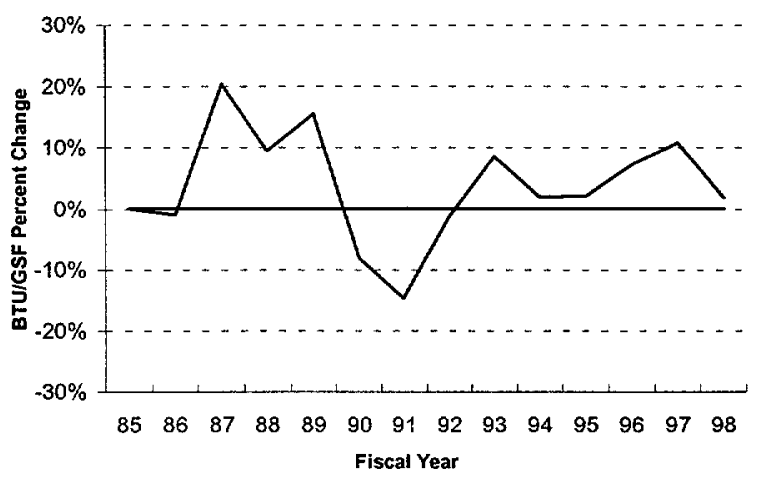

HHS Buildings Energy Use and Costs, FY98

$\begin{array}{lrr} & \text { BBtu } & \text { \$(Thou.) } \\ \text { Electricity } & 2,891.2 & 46,685.0 \\ \text { Fuel Oil } & 367.6 & 2,165.0 \\ \text { Natural Gas } & 3,332.2 & 12,714.0 \\ \text { Propane } & 131.0 & 900.0 \\ \text { Coal } & 37.0 & 92.0 \\ \text { Purchased Steam } & 194.1 & 2,672.0 \\ & & \\ \text { Total } & 6,953.1 & 65,228.0\end{array}$

HHS has developed an extensive energy management program to provide both technical and administrative assistance to the Operating Divisions (OPDIVs) on all energy related issues. At the foundation of this program, are the OPDIV 10-Year Audit Plans that outline an action plan for completing comprehensive energy audits. The audits identify energy conservation measures that are either funded directly by the facility or targeted for alternative financing vehicles.
Energy and water conservation projects and initiatives performed during FY 1998 include:

- Office of the Secretary (OS), Hubert H. Humphrey Building, Washington, DC. Solar film was installed on the windows; other solar applications are being analyzed. The energy management control system will be reprogrammed to automatically curtail the HVAC operations during unoccupied hours.

- Centers for Disease Control and Prevention (CDC). HVAC and lighting upgrades were completed at an approximate cost of $\$ 170,200$. A water conservation project, that was funded with FY 1997 dollars and completed in FY 1998, is saving approximately 15 million gallons of water per year. This project involved the implementation of a recirculating cooling tower to provide chilled water to HVAC water source cooling equipment. This system previously used cold chiller water that was dumped down the sewer drain after only one pass through the equipment.

- Indian Health Service (IHS). Energy conservation projects, such as energy management control system implementation, HVAC upgrades, lighting retrofits, boiler and chiller replacements, building envelop upgrades, and variable speed drive installations, were completed with $\$ 1,456,000$ of nonrecurring maintenance and improvement funds (direct agency funding). The use of a groundsource thermal water closed loop system for heating an IHS hospital eliminated the need for natural gas boilers, thus reducing the emissions of the boiler operation.

- National Institutes of Health (NIH) Bethesda Campus, Bethesda, Maryland. The Bethesda Campus Power Plant is being expanded to provide the necessary utilities for new buildings on campus and renovated existing buildings. During the design and construction of the facility renovation, energy conservation measures have been implemented such as, high efficiency chillers with steam turbine drives, variable frequency drive fan motors for the cooling towers, chilled water variable speed secondary pumping, and free cooling capabilities from a heat exchanger which uses condenser water to generate chilled water during winter months. The annual estimated savings of these measures is 
$\$ 1.59$ million or 6 percent of the annual energy costs.

IHS hospitals in the Aberdeen Area make extensive use of solar technologies, with current efforts under way to improve the efficiency of their operation. During FY 1998 , one of the facilities installed a thermal protection system to prevent dangerous overheating. Solar lighting was also planned for one of the hospitals in FY 1998.

\section{Energy Showcases}

HHS has designated the National Institute of Health (NIH) Frederick Cancer Research and Development Center in Frederick, Maryland, and the Hubert $\mathrm{H}$. Humphrey Building as energy showcase buildings.

\section{Training}

OS held a two day seminar in FY 1998. HHS energy managers and engineers from across the country attended to hear speakers from DOE, the National Renewable Energy Laboratory, Pacific Northwest National Laboratory, HHS, and private industry present a wide array of energy efficiency topics. These included energy auditing, renewable energy, water conservation, ESPCs, energy awareness, energy-efficient operations and maintenance, competitive utilities, greening of the government, fuel procurement, facility recommissioning, and new technologies.

\section{Funding}

Although HHS is fine-tuning each OPDIV's energy management plan in order to fully meet the Executive Order 12902 energy targets, HHS needs further funding and support staff to identify and implement projects. In prior years, direct agency funding was the primary vehicle for implementing energy projects. Unfortunately, in FY 1998, funding for energy and water efficiency projects decreased by 24 percent to $\$ 2.2$ million.

\section{Energy Savings Performance Contracts}

In FY 1998, several HHS facilities entered into ESPtype contracts and are evaluating the energy contractors' recommendations for conservation projects. The outlook for FY 1999 is promising, as many more HHS facilities are expected to sign energy savings performance-type contracts.

The IHS Aberdeen Area office is working with engineers from the IHS Engineering Services in Seattle to prepare an ESPC with DOE. A delivery order is expected to be issued in FY 1999.
The IHS Oklahoma Area is working on an ESPC with Trane for conservation projects at a hospital and three health clinics. A contract is planned for FY 1999.

A Super ESPC is being pursued by the Oklahoma City Area that includes three major service areas and hospitals. The Area Office has been working with DOE and NREL to review the potential projects and a MOU has been signed. The six ESCOs under the Super ESPC have met with the Area office to discuss their capabilities and qualifications and the Area Office procurement and technical staff have attended Super ESPC training. Currently, IHS is considering the implication of a compact of the facilities and the long term financial obligation of transferring such a contract to a tribe.

\section{Utility Partnerships}

The NIH Frederick Cancer Research and Development Center (FCRDC) located in Frederick, MD, began implementation of energy conservation projects in FY 1998, under the Basic Ordering Agreement with Allegheny Power, the local utility. In FY 1998, the NIH campus began the process of choosing an ESP-type contract to finance energy and water conservation measures that produce stable, measurable, and verifiable savings. This contract is expected to be signed in FY 1999.

The Food and Drug Administration (FDA) National Center for Toxicology Research (NCTR) entered into a GSA Area Wide Public Utilities contract with Entergy. This contract has been valued at $\$ 9$ million in savings over an eight year period. The annual energy savings have been estimated at 20 to 27 percent. The final contract is expected to be signed in early FY 1999. The Food and Drug Administration (FDA) is establishing a contract at the Module One facility in Laurel, Maryland. This contract will be with the local utility and is expected to be finalized in FY 1999. In addition, an ESPC for a lighting retrofit project will be signed in FY 1999 for the FDA Winchester Analytical Engineering Center in Woburn, Massachusetts.

The Program Support Center (PSC) Parklawn Building will sign a utility agreement in FY 1999 to implement lighting, high-efficiency motors, and water-saving projects. Centers for Disease Control and Prevention (CDC) in Atlanta, Georgia, are utilizing a GSA Area Wide Public Utilities to implement energy projects in the one million square feet of buildings. They are currently awaiting the utility company's proposal and 
after evaluation of the proposal will determine the implementation action plan.

HHS facilities are beginning to purchase natural gas on the spot market. In FY 1998, PSC will purchase deregulated gas from Washington Gas Energy Services, with expected savings of approximately $\$ 25,000$ for the year. The IHS Oklahoma Area is also considering this type of purchase. The NIH Bethesda Campus purchases most of its natural gas on the spot market through the Defense Energy Service Center's Natural Gas Program.

\section{Environmental Activities}

HHS contracts offices follow procurement guidelines established in the CFR when purchasing energy efficient equipment. At the IHS Billings Service Area, new energy-efficient products are reviewed by the Facilities Management Branch engineers using the Sweet Source product information catalog.

The CDC water conservation project is saving 15 million gallons of water annually. The new IHS ground-source thermal water closed loop system for heating an IHS hospital eliminated the need for natural gas boilers, thus reducing the emissions of the boiler operation.

The NIH Bethesda Campus has made significant strides in reducing overall source emissions by converting the central boilers from petroleum-based fuel to natural gas and upgrading the control and burner systems for more efficient operation. The conversion has reduced fuel oil consumption by 88 percent, from approximately $9,720,000$ gallons in 1995 to $1,150,000$ gallons in 1998 and the power plant's total boiler emissions were reduced from 866 to 144 tons or 83 percent.
In FY 1998, the HHS Energy Officer and the OPDIV energy coordinators met with EPA to discuss the Federal ENERGY STAR Buildings Program. Each HHS OPDIV will sign a memorandum of understanding for the program. These will be forwarded from the HHS Energy Office to each OPDIV head with a brief description of the program and a letter stressing the benefits of energy conservation and becoming part of the ENERGY STAR $\otimes$ program.

\section{Energy Management Contact}

Mr. Scott Waldman

Department-Wide Energy Manager

U.S. Department of Health and Human Services

Room 709D

Hubert H. Humphrey Building

200 Independence Avenue, SW

Washington, DC 20201

Phone: 202-619-0719

Fax: 202-619-2692 


\section{DEPARTMENT OF HOUSING AND URBAN DEVELOPMENT (HUD)}

\section{Energy Efficiency Performance and \\ Implementation Strategies}

During FY 1998, the Department of Housing and Urban Development reported a 11.8 percent decrease in buildings consumption in Btu per gross square foot compared to FY 1985.

\section{HUD Performance Toward Buildings Energy Reduction Goals}

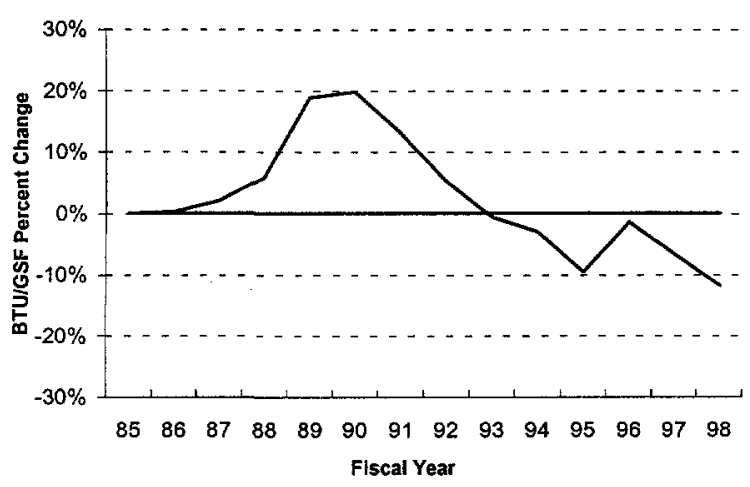

HUD Buildings Energy Use and Costs, FY98

$\begin{array}{lrr} & \text { BBtu } & \text { \$(Thou.) } \\ \text { Electricity } & 83.2 & 1,803.0 \\ \text { Natural Gas } & 0.2 & 2.2 \\ \text { Purchased Steam } & 19.7 & 295.0 \\ & & \\ \text { Total } & 103.1 & 2,100.2\end{array}$

The following are energy conservation measures (ECMs) completed at the HUD Headquarters Building during FY 1998:

- The variable-frequency drives upgrade on the building's eight main air handlers and return fans was completed in December 1997.

- The automated control system for on/off control of the building's 1,584 window fan coil units was completed in March 1998.

As a result of these and previous efforts, an energy savings of 6.4 billion Btu was realized over FY 1997. An additional energy savings of 4 billion Btu is projected for FY 1998.
Initiatives for FY 1999 include a lighting retrofit throughout the headquarters building. T-12, 34-watt lights, and magnetic ballasts will be replaced by $\mathrm{T}-8$, 32 -watt lights with reflectors and electronic ballasts.

HUD plans to use local utilities to perform an energy audit, which should help identify additional ECMs that could be implemented in the future.

\section{Energy Showcase Facilities}

The HUD Headquarters Building is a DOE Energy Saver Showcase facility. An audit will be performed during FY 1999 to incorporate advanced technologies and practices for energy efficiency, water conservation, and solar and other renewable energy sources.

\section{Training}

HUD's energy coordinators attended the ESPC workshop given through DOE's Federal Energy Management Program.

\section{Funding}

Funding for HUD's ECMs has been provided by the GSA Energy Conservation Program, by DOE, and through HUD's repair and alteration funds as they are available.

\section{Utility Partnerships}

During FY 1998, HUD continued participation in Potomac Electric Power Company's Electrical Load Curtailment Program. This will continue in FY 1999.

\section{Vehicles}

HUD has only four EPACT-covered fleet vehicles, two of which are exempted. HUD proposes to acquire two alternative fuel vehicles through their delegated commercial leasing procedures. This is dependent on the leasing industry having readily available vehicles.

\section{Environmental Activities}

Products purchased during FY 1998 were all in compliance with Federal regulations regarding ENERGY STAR ${ }^{\circledR}$ equipment using the GSA schedule.

HUD has implemented a recycling program and has replaced existing CFC chillers with non-CFC energyefficient chillers. 
Management employees' performance evaluations include energy management and maintenance criteria. Five HUD employees were recognized for their contributions for energy management programs through the FEMP "You Have the Power" energy awareness campaign.

\section{Energy Management Contact}

Ms. Elaine Robinson

Director, Building Operations Division

Department of Housing and Urban Development

Room 5180

$4517^{\text {th }}$ Street, SW

Washington, DC 20410-3000

Phone: 202-708-2711 x227

Fax: 202-708-0299 


\section{DEPARTMENT OF THE INTERIOR (DOI)}

\section{Energy Efficiency Performance and \\ Implementation Strategies}

In FY 1998, the Interior Department reported a decrease in energy consumption in buildings of 15.6 percent in Btu per gross square foot compared to FY 1985.

\section{Interior Performance Toward Buildings Energy Reduction Goals}

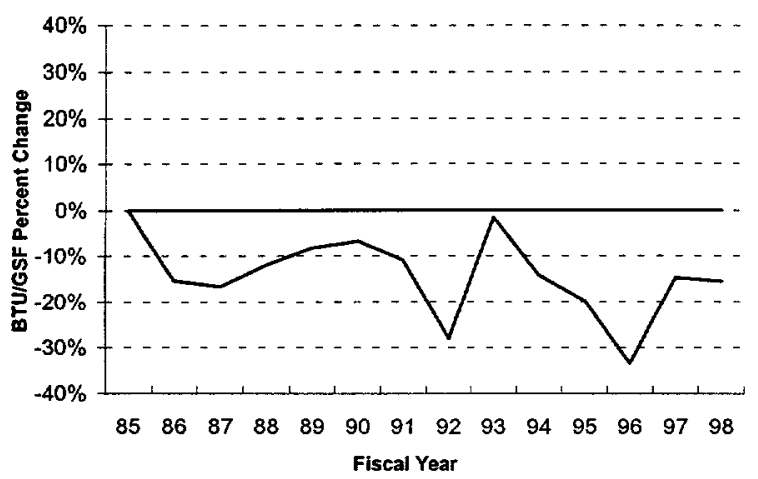

Interior Buildings Energy Use and Costs, FY98

$\begin{array}{lrr} & \text { BBtu } & \text { S(Thou.) } \\ \text { Electricity } & 1,523.8 & 32,909.7 \\ \text { Fuel Oil } & 513.7 & 4,349.7 \\ \text { Natural Gas } & 1,210.2 & 5,532.0 \\ \text { Propane } & 451.0 & 3,184.3 \\ \text { Coal } & 1.6 & 1.0 \\ \text { Purchased Steam } & 45.9 & 701.9 \\ \text { Other } & 1.2 & 3.2 \\ & & \\ \text { Total } & 3,747.4 & 46,681.8\end{array}$

The DOI Energy Management Plan for Buildings and Facilities, revised in June 1995 to meet requirements of EPACT and Executive Order 12902, provides guidance to its Bureaus in establishing and implementing energy management programs.

The Bureau of Reclamation recently issued a supplement to Departmental Manual 752 Energy Management Program. The supplement establishes policy on buildings powered by station service, beneficial landscape practices, and use of recovered materials.

Each bureau has developed, or is developing, a bureau energy management plan based on the guidance provided by $D O E$.
Operation and maintenance procedures have been adopted at many DOI bureaus that require all purchases of energy-consuming devices be evaluated on energy efficiency characteristics. Procedures also require the replacement of incandescent lamps with compact fluorescent lamps, fluorescent lamps with lower wattage and more efficient lamps, worn-out air conditioners and heat pumps with high energy rating units; and faucets and toilets with low-water consumption units. Some procedures also call for the installation of timing lights and motion sensors, improved landscape watering practices, and installation of low-water xeriscape plants in certain areas.

In FY 1998, DOI established the Maintenance Management Systems Working Group in conjunction with the development of the FY 2000 budget request to conduct a review of maintenance data requirements, systems, and applications.

The following energy and water conservation audits and initiatives were under way during FY 1998:

\section{Bureau of Reclamation}

- Audits performed in the Bureau of Reclamation included the Fort Simcoe and Columbia Basin Job Corps Centers. Preliminary audits of several sites in Boulder City, Nevada, were also conducted.

- Xeriscaping was used at the newly constructed Centennial Job Corps Center in Nampa, Idaho. Drip irrigation, rock mulch, drought-tolerant grasses, and water-efficient spray heads were all utilized. Xeriscaping is also being implemented at the Lower Colorado Regional Office.

- A water conservation visitor center is being planned at Folsom Dam, California.

\section{Fish and Wildlife Service}

- The Fish and Wildlife Service is in the process of completing the Mora National Fish Hatchery and Technology Center of the Southwestern Fisheries Technology Center in New Mexico. Extensive water reuse facilities are incorporated into the design of the hatchery. In FY 1998, the Service received $\$ 2$ million in construction funds to complete the project. This enabled the unfunded por- 
tion of Phase III (office and wet laboratory buildings, settling pond, paving, and other projects) to be completed and operations to begin.

- The Fish and Wildlife Service nominated several sites for energy audits utilizing the SAVEnergy survey program conducted through DOE's FEMP. In FY 1998, five Fish and Wildlife Service surveys were completed. These surveys identified energy conservation opportunities and retrofits whose estimated costs exceeded FY 1998 funding.

The Main Interior Building Complex (a GSA-delegated facility) implemented retrofits, including chiller replacements, and contracted for lighting improvements in the Main Interior Building. Annual savings resulting from the two retrofits are estimated at $\$ 489,000$.

DOI recognizes the cost-saving potential for the development and implementation of renewable energy resource projects and has developed a Renewable Energy Plan, which was signed in February 1998 and forwarded to DOE. The plan requires identification of opportunities for development of alternative energy resource projects if development of the resource is economically, environmentally, and technically feasible and energy produced can be used by DOI facilities.

Some bureaus, including the Fish and Wildlife Service, require their engineers to implement use of passive solar strategies, as appropriate, in the design of new buildings.

The Fish and Wildlife Service retrofitted a solar project at Sand Lake National Wildlife Refuge (NWR) in South Dakota, and initiated a solar cooling project at Cabo Rojo NWR in Puerto Rico. Future renewable energy projects include photovoltaic systems at the Farallon Islands NWR in California and the Havasu NWR in Arizona. A solar hot water system is planned for the Imperial NWR, Arizona.

The National Park Service (NPS) uses an innovative strategy to augment funding for some photovoltaic projects. Photovoltaic installations are used as training sessions, for which fees are charged. NPS uses these fees to subsidize the project costs. In FY 1998, this strategy was used to install photovoltaics at a remote ranger station on the Schivitz Plateau at Lake Mead National Recreational Area in Nevada.

Two off-grid 6.4-kilowatt photovoltaic systems were activated at the Channel Islands National Park in
California in May 1998. In August 1998, four 9-kilowatt equivalent solar hot water systems were installed on the rooftops of the residential units. Due to the expense of delivering fuel from the mainland, the simple payback period is very short at just over 2 years.

The Bureau of Land Management (BLM) is exploring the possibility of installing two or three wind turbines ( 30 to 50 kilowatts each) at the Weber Basin Job Corps Center in Ogden, Utah.

In 1998, at BLM's Parriette Wetlands Administrative Facility in Utah, a photovoltaic system, including 16 64-watt modules, batteries, inverters, and power center were installed. The procurement included three other photovoltaic systems for sites in Arizona, Idaho, and Alaska. Quantity puchases help keep prices competitive.

NPS and BLM have completed, or identified for completion, 114 photovoltaic projects throughout Alaska, Arizona, California, Colorado, Florida, Hawaii, Idaho, Michigan, Mississippi, Montana, North Carolina, Nevada, New Mexico, Oregon, Utah, Washington, and Wyoming.

\section{Energy Showcases}

Two Fish and Wildlife Service buildings were recognized as showcases by DOE in FY 1998. The Wichita Mountains Visitor Center in Indiahoma, Oklahoma, displays earth coupled heat pumps. The Prairie Learning Center in Prairie City, Iowa, displays earth coupled heat pumps, earth sheltering, clerestory lighting, lowflush plumbing fixtures, and wetlands waste water treatment.

Reclamation has four showcase facilities. Glen Canyon Dam Visitor's Center demonstrates energy conservation within a hydroelectric generating facility. Lighting retrofits and occupancy sensors are being installed throughout the facility. Toilets were replaced with lowflush units, single pane windows with insulated glass, and the existing solar hot water heating system was repaired.

The Denver Federal Center showcase facility is a joint effort between Reclamation, GSA, DOE, EPA, the local water utility, and four manufacturers of watersaving devices. This 2-year project demonstrates and evaluates water conservation technologies and provides a learning center for other Federal agencies, private organizations, and the general public. The project will 
also document the performance of water conservation devices, determine life-cycle cost savings, and determine if improvements are needed before deployment in the Federal sector.

Reclamation's Pacific Northwest Region showcase facility is the new Centennial Job Corps Center in Nampa, Idaho. A dedication ceremony for the new center was held in October 1997. Included at the October dedication ceremony was an exhibit that featured the energy-efficient and water-conservation technologies.

The Davis Dam Building in Bullhead City, Arizona, highlights lighting and electric savings opportunities.

NPS's showcase is the Golden Gate Club at Golden Gate National Recreation Area in California. The U.S. Geological Survey's EROS Data Center's Mundt Building in South Dakota exhibits mechanical upgrades.

\section{Training}

Energy managers involved in building energy efficiency and water conservation have attended workshops offered by DOE, GSA, EPA, the Association of Energy Engineers, public utilities, and at Bureau energy coordinators meetings. Training material is routinely distributed, and energy managers are encouraged to attend as much training as local funding will allow.

DOI was well represented at the SOL TECH conference in Albuquerque, New Mexico, in June 1998 and at DOE's Energy ' 98 Conference in Bellevue, Washington, in August 1998.

DOI was represented in the DOE video on ESPCs and continued collaboration with DOE and Camber Corporation in the development of the Federal Energy Manager Job and Task Analysis effort in FY 1998.

\section{Funding}

DOI funded $\$ 8.3$ million in retrofit and capital equipment for FY 1998. Estimated project funding for FY 1999 is $\$ 8.2$ million, and $\$ 6.3$ million for FY 2000. As in previous years, DOI funding for retrofit and capital improvements comes from the Bureaus' operations, maintenance, construction, and rehabilitation funds.

In GSA-assigned buildings, GSA's energy fund will continue to be a primary source of funding for retrofit projects.

\section{Energy Savings Performance Contracts}

DOI continues to explore locations where ESPCs might be effectively implemented. Using indefinite delivery, indefinite quantity contracts developed by NPS and DOE is expected to increase familiarization with and the number of ESPCs. Bureaus are very optimistic about participating in DOE's Super ESPCs. In February 1998, DOI signed a memorandum of understanding with DOE for participation in the DOE regional Super ESPCs.

Presently, at the Lake Mead National Recreational Center in Nevada, NPS is exploring the possibility of building five park entrance stations that would be powered by photovoltaics and heated by ground source heat pumps. NPS is very interested in using DOE's technology-specific, photovoltaic Super ESPC to complete this project.

\section{Utility Partnerships}

Each Reclamation office is encouraged to periodically check with their utility to determine if any incentives are being offered.

The U.S. Geological Survey consults with servicing utilities at least annually to ensure that each facility has the lowest possible rate schedule. High-energy-use systems are scheduled to take advantage of off-peak rates.

Fish and Wildlife Service field stations also maintain contact with their local utilities in order to obtain any available demand-side management services.

NPS and Pacific Gas and Electric Company negotiated an innovative demand-side management contract that pays NPS for energy saved. To obtain the rebates, a preretrofit and postretrofit energy audit is performed to identify the savings.

\section{Vehicles}

Currently, DOI has approximately 400 alternative fuel vehicles in about 39 states at more than 100 locations. About 75 percent of DOI's AFVs use an alcohol-based fuel (primarily methanol/gasoline blend) and 20 percent use natural gas or propane. Less than 5 percent of the AFVs are powered by electricity or bio-diesel derived from industrial rapeseed, canola, or soybeans. With a few exceptions, Interior's AFVs with dedicated natural gas fuel systems and those that can use methanol (M85) and ethanol (E-85) are leased through the General Services Administration. Vehicles in the fleet that have 
been retrofitted to operate on natural gas and liquefied petroleum gas are Interior-owned.

DOI has established a number of high profile inititiatives at Yosemite National Park, Grand Canyon National Park, Zion National Park, Golden Gate National Recreation Area, Arcadia National Park, Rocky Mountain National Park, Back Bay National Wildlife Refuge, and Patuxent National Wildlife Refuge that demonstrate commitment to the use of AFVs in light duty vehicles, as well as transit vehicles and medium and heavy duty vehicles. Most of these projects are possible through the willingness of partners in both the private and public sectors.

Interior bureaus set aside $\$ 250,000$ in FY 1998 to cover the incremental cost of AFVs leased through GSA. For FY 1999 and beyond, Interior proposed and successfully coordinated with GSA in establishing Interior as their first customer to have the incremental cost of AFVs leased through the GSA Interagency Fleet Management Program spread among all vehicles leased through GSA. This new financing approach will result in a significant increase in the introduction of AFVs into Interior's fleet.

\section{Environmental Activities}

DOI is currently making every effort within budgetary limitations to implement applicable rules and regulations regarding procurement of energy-efficient goods and services. DOI participated in the Best Practices Work Group for Environmentally Preferable and Energy-Efficient Purchasing sponsored by OMB, EPA, and DOE.
In June 1998, NPS sponsored a strategic planning workshop called "Making the National Parks a Showcase for an Energy Efficient Future." The workshop was a significant step in a broader, collaborative, sustainable energy initiative between DOI and DOE. The workshop will promote energy efficiency and renewable energy technologies and help educate park visitors.

\section{Energy Management Contact}

Mr. John Moresko

Property Management Specialist

Office of Acquisition and Property Management

U.S. Department of the Interior

Main Interior Building, Room 5512

1849 C Street, NW

Washington, DC 20240

Phone: 202-208-5704

Fax: 202-208-6301 


\section{DEPARTMENT OF JUSTICE (DOJ)}

\section{Energy Efficiency Performance and \\ Implementation Strategies}

In FY 1998, the Department of Justice reported a decrease of energy consumption in buildings of 40.2 percent in Btu per gross square foot compared to FY 1985.

\section{Justice Performance Toward Buildings Energy Reduction Goals}

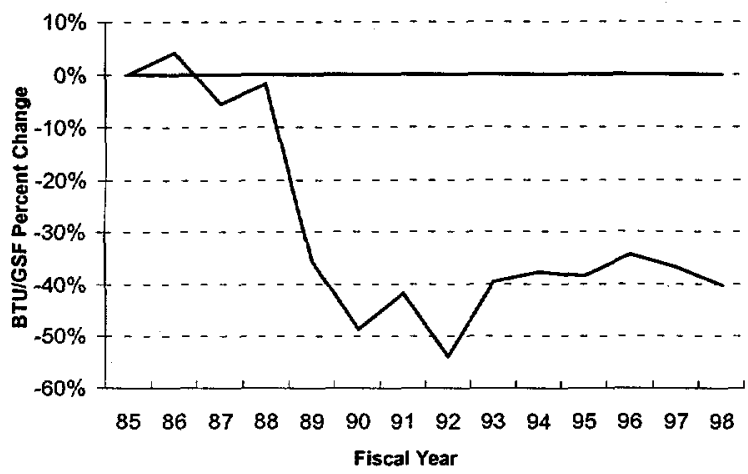

Justice Buildings Energy Use and Costs, FY98

$\begin{array}{lrr} & \text { BBtu } & \text { S(Thou.) } \\ \text { Electricity } & 3,076.2 & 48,762.5 \\ \text { Fuel Oil } & 93.4 & 594.2 \\ \text { Natural Gas } & 4,266.7 & 20,906.7 \\ \text { Propane } & 9.7 & 5.6 \\ \text { Coal } & 67.2 & 68.0 \\ \text { Purchased Steam } & 250.8 & 2706.9 \\ \text { Other } & 19.0 & 0.0 \\ & & \\ \text { Total } & 7,783.0 & 73,043.9\end{array}$

DOJ has reviewed its energy management and water conservation plans. During FY 1999, an extensive review of these plans will be undertaken to incorporate the most recent Executive Order requirements.

Energy conservation highlights from FY 1998 include:

\section{Bureau of Prisons (BOP)}

- Federal Correctional Institute (FCI) Schuylkill, Pennsylvania. A project was established to replace and upgrade lighting fixtures. Annual electrical savings are estimated to exceed 840,000 kilowatthours. Simple payback will be within six years.
- United States Penitentiary (USP) Lewisburg, Pennsylvania. A lighting retrofit was performed. Annual electrical savings are estimated at more than 1 million kilowatt-hours. Simple payback will occur within four years.

- FCI McKean, Pennsylvania. The HVAC system was upgraded, providing estimated annual savings of approximately 663,000 kilowatt-hours of electricity and 65,000 therms of natural gas. Simple payback will occur in four years.

- FCI Fairton, New Jersey. A lighting retrofit was performed, producing estimated annual electrical savings of more than 1 million kilowatt-hours. Simple payback should occur in less than one year.

- Metropolitan Correctional Center, New York, New York. Certain light fixtures were replaced, producing estimated annual electrical savings of almost 80,000 kilowatt-hours. Simple payback will occur in seven years.

- USP Marion, Illinois. Selected windows were replaced, producing estimated savings of more than 170 tons of coal annually. Simple payback will occur in 10 years.

- FCI Petersburg, Virginia. Lighting fixtures in the housing units were replaced, producing estimated annual savings of more than 180,000 kilowatthours. Simple payback will occur in seven years.

- USP Leavenworth, Kansas. Lights in three cell houses were replaced, producing estimated annual savings in excess of 680,000 kilowatt-hours per year. Simple payback will occur in five years.

- FCI Oxford, Wisconsin. Selected HVAC units were upgraded, providing estimated annual savings in excess of 8,000 kilowatt-hours per year, with significant monetary benefits from decreased maintenance. Simple payback will occur in five years.

BOP completed four energy audits in FY 1998, bringing its total number of surveys completed to 70 . 


\section{Federal Bureau of Investigation (FBI)}

- J. Edgar Hoover building (JEH), Washington, DC. At least $\$ 690,000$ worth of energy conservation projects will be implemented in FY 1998 and 1999, including replacing garage lights, installing high-efficiency motors, and installing variablespeed drives for pumps. JEH received an energy audit by GSA in 1996. As a result, a new energy management system is being designed. GSA has allocated $\$ 1.8$ million to install this system; contract award was expected by November 1998. Two additional lighting projects are expected to be implemented in FY 1999.

- FBI Academy, Quantico, Virginia. Equipment is being converted from fuel oil to natural gas. The 25 -year-old chiller refrigeration equipment is being replaced with models 30 percent more efficient.

The new FBI laboratory in Quantico has been designed with the latest energy-saving methods appropriate for its function. The FBI's Clarksburg, West Virginia, facility also incorporated many energy-conservation features in its design and construction.

\section{Immigration and Naturalization Service (INS)}

- The Batavia, New York, Federal Detention Facility was completed in FY 1998. Project design specified the use of energy-efficient materials and equipment. Electrical power is supplied by an INSowned transformer rather than from the local utility, saving more than $\$ 60,000$ annually.

- The Krome Service Processing Center in South Florida is being designed with energy-efficient materials and equipment, including solar.

- A Border Patrol Station in Remey, Puerto Rico, is being designed and built using energy-efficient material and technologies, including solar electrical backup.

\section{Energy Showcases}

INS will attempt to showcase three facilities in FY 1999. DOJ will establish a goal of designating at least one facility from each of its bureaus in FY 1999 as a showcase facility.

\section{Training}

DOJ periodically conducts meetings with its Bureaus to disseminate information and provide guidance.

Energy conservation has been a topic at BOP's biannual Facilities Management training course. The course generally has 25 participants from throughout BOP. A life-cycle costing workshop has been provided at some of the more recent courses.

A videotape highlighting energy conservation projects completed at the Federal Prison Camp in Duluth, Minnesota, was produced in FY 1995 and has recently been edited to update its content. This tape will be shown at training sessions.

\section{Energy Savings Performance Contracts}

BOP entered into an energy savings performance contract (ESPC) in FY 1996 at FCI Phoenix, Arizona. This ESPC is for the installation of a solar hot water heating system that will provide a large percentage of the domestic water. Construction was to begin in early FY 1998. Operation of the system is anticipated to begin in early FY 1999.

\section{Utility Partnerships}

Electric and natural gas utilities have worked with BOP by providing services, guidance, and financial incentives involving lighting and HVAC systems. The cost savings generated by these efforts have allowed for the funding of additional projects.

\section{Environmental Activities}

BOP and FBI include energy and water conservation criteria in their position descriptions and performance evaluations for relevant staff members.

DOJ encourages its Bureaus to establish separate award programs for energy and water conservation. Employees are also nominated for the annual Federal Energy and Water Management Awards.

\section{Energy Management Contact}

Mr. William Lawrence

Energy Program Manager

U.S. Department of Justice

Main Justice Building, Room 1111

950 Pennsylvania Avenue, NW

Washington, DC 20530-0001

Phone: 202-616-2417

Fax: 202-514-4929 


\section{DEPARTMENT OF LABOR (DOL)}

\section{Energy Efficiency Performance and Implementation Strategies}

In FY 1998, the Department of Labor reported a 0.01 percent increase in buildings consumption in Btu per gross square foot compared to FY 1985.

\section{Labor Performance Toward Buildings Energy Reduction Goals}

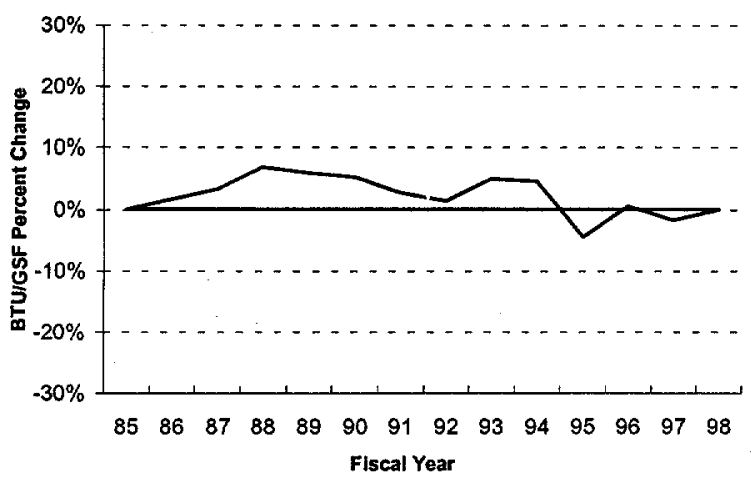

DOL Buildings Energy Use and Costs, FY97

$\begin{array}{lrr} & \text { BBtu } & \text { \$(Thou.) } \\ \text { Electricity } & 791.9 & 16,187.8 \\ \text { Fuel Oil } & 209.4 & 1,258.0 \\ \text { Natural Gas } & 1,108.9 & 5,566.4 \\ \text { Propane } & 16.7 & 287.8 \\ \text { Coal } & 14.7 & 49.4 \\ \text { Purchased Steam } & 48.7 & 686.7 \\ & & \\ \text { Total } & 2,190.2 & 24,036.1\end{array}$

Six energy audits were completed during FY 1998. The North Texas Cement Quarry and Plant Midlothian, TX, part of the DOL's Mine Safety and Health Administration, was audited under DOE/FEMP's SAVEnergy Audit Program. Implementation of identified energy conservation measures will be completed using DOE's Central Region Super ESPC program.

The Job Corps, which falls under the Employment and Training Administration has been particularly active during FY 1998. Total square footage for Job Corps facilities increased slightly during the fiscal year, and now stands at 16.7 million square feet. Approximately one-third of the space is leased. The contract-operated Job Corps facilities have reduced fuel oil usage by 45 percent since 1985. Consumption has dropped from about 2.6 million gallons during the 1998 fiscal year.
Whenever an alternative energy source is available, life-cycle cost-effective, and practical, Job Corps facilities are converted to that energy source.

There is one Job Corps Center that utilizes solar energy for domestic water heating. It is anticipated that an existing non-functional solar water heater at the Gary, Indiana Center will be decommissioned.

\section{Energy Showcase}

The Frances Perkins Building has been designated as a showcase facility and engages in activities to display how it is saving energy. Participation in DOE/FEMP's "You Have the Power" campaign has once again proved valuable to energy conservation efforts at the Department of Labor.

\section{Training}

Six Department of Labor employees have attended and participated in FEMP-sponsored training, conferences, and other energy/environmental seminars throughout the year.

\section{Funding}

The Department of Labor receives most of its funding for energy efficiency projects from the General Service Administration's Federal Buildings Fund. This funding is supplemented by monies from the Department's operation, maintenance, repair, and construction accounts, as available.

\section{Energy Savings Performance Contracts}

The Job Corps is currently involved in two projects using the Department of Energy's Regional Super ESPC program. The DOE Central Region selected the Gary, Indiana Job Corps Center as one of two Federal facilities to be included in their Request for Proposal solicitation.

DOE awarded an Indefinite Delivery/Indefinite Quantity contract. The Department of Labor developed and issued a Delivery Order Request for Proposal. The selected energy service company is currently working on its project proposal. It is anticipated that the project scope will include lighting upgrades, HVAC equipment and controls, and the refurbishment and decommissioning of a non-operational solar hot water heating system. 


\section{Utility Partnerships}

The Job Corps is currently working on two projects which utilize GSA Area-Wide Contracts. These projects include, but are not limited to, HVAC improvements, lighting upgrades, window replacements, and building control system improvements.

\section{Environmental Activities}

The Department of Labor has developed a strategic plan in accordance with requirements of Executive Orders with the goal of improving waste prevention, recycling, and the purchase and use of recycled-content and environmentally preferable products and services. A DOL Agency Environmental Workgroup has been established with a designated Recycling Coordinator. DOL is developing a Web site on recycling to educate all employees and the public on recycling within DOL. Employees have submitted suggestions on achieving recycling goals.
Recycled carpet has been purchased by DOL agencies during the fiscal year and new contracts are being reviewed for recycled content in materials. Toner cartridges are now recycled. A contract with a recycling company has been established, with revenues going to the DOL Child Development Center. Containers are provided throughout the Frances Perkins Building for recycling newspapers, cans, bottles, and white paper. The purchase of ENERGY STAR $(B$ computer equipment also continues throughout all DOL agencies.

\author{
Energy Management Contact \\ Patricia C. Clark \\ Office of Facilities Management \\ U.S. Department of Labor \\ Room S-1521 \\ 200 Constitution Avenue, NW \\ Washington, DC 20210 \\ Phone: 202-219-5205 ext 115 \\ Fax: 202-501-6886
}




\section{DEPARTMENT OF STATE (ST)}

\section{Energy Efficiency Performance and Implementation Strategies}

In FY 1998, the Department of State reported energy consumption in all overseas facilities, which was excluded in previous years. The apparent increase in buildings Btu/GSF of 84.9 percent is caused by the nonreporting of this data in FY 1985.

\section{State Performance Toward Buildings Energy Reduction Goals}

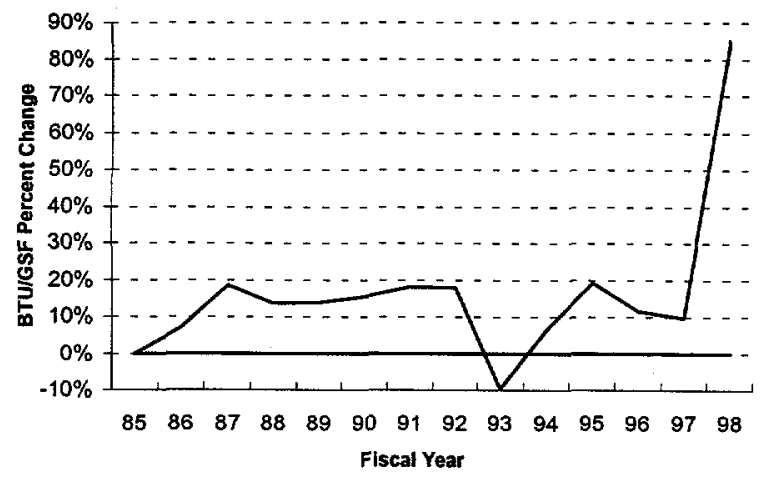

State Buildings Energy Use and Costs, FY98

$\begin{array}{lrr} & \text { BBtu } & \text { \$ (Thou.) } \\ \text { Electricity } & 4,758.9 & 40,991.9 \\ \text { Fuel Oil } & 1,498.0 & 4,210.0 \\ \text { Natural Gas } & 1,113.0 & 1,875.1 \\ \text { Purchased Steam } & 52.0 & 920.0 \\ & & \\ \text { Total } & 7,422.7 & 47,997.0\end{array}$

In FY 1998, the State Department conducted two comprehensive survey/audits. One of these was technology-specific. Each manager has developed an energy plan to complete energy conservation opportunities identified.

Energy conservation projects were accomplished in seven buildings, with most focusing on lighting upgrades to T-8 fluorescent tubes, reflectors and ballasts, and replacement and/or upgrades to motors using energy-efficient alternatives. Weatherization, roofing, HVAC controls, and better maintenance schedules for more optimum energy-efficient operation have also been accomplished.
Three other properties have been surveyed for energy conservation opportunities, identifying upgrades to basic lighting and humidification equipment, and pumps and motors. All remaining buildings will be reviewed within the next 2 years.

During FY 1998, the Office of Foreign Buildings Operations (FBO) devised a means for assessing energy conservation progress in all overseas buildings, without creating an unmanageable administrative burden. The result uses fiscal data already collected annually by the regional bureaus, FBO's computerized property inventory, and a small selection of utility bills which FBO will request from each post annually.

Between 1991 and 1997, FBO estimates that annual energy use per square foot of overseas facilities declined by approximately 16.7 percent.

In FY 1998, comprehensive surveys were performed for State Department properties at the following U.S. Embassies:

- Antananarivo, Madagascar;

- Brussels, Belgium;

- Dar Es Salaam, Tanzania;

- Helsinki, Finland;

- Jakarta, Malaysia;

- Monrovia, Liberia;

- Paris, France;

- Santo Domingo, Dominican Republic;

- Hong Kong; and

- Prague, Czech Republic,

Comprehensive surveys were also performed at the following Consulate Generals:

- Fukuoka, Japan;

- Osaka-Kobe, Japan;

- Naha, Japan; and

- Sapporo, Japan

By the end of FY 1998, 18 energy conservation projects resulting from these surveys were initiated. Approximately 44 percent of the total available space in the State Department's worldwide facility inventory has been surveyed to date. 
Overseas posts with solar hot water projects under way include residences in:

- Dar Es Salaam, Tanzania;

- Gaborone, Botswana;

- Port Louis, Mauritius;

- Windhoek, Namibia;

- Chennai, India;

- Mumbai, India;

- New Dehli, India,

- Tegucigalpa, Honduras; and,

- Dakar, Senegal.

The design for a new office building in Tashkent, Uzbekistan includes passive solar exterior shading features to control solar gain.

FBO anticipates replacing about half the State Department's worldwide office building inventory in the next ten years. Future major new construction projects will comply with the EPA/DOE ENERGY STARß Building requirements.

State was the first Government agency to enter into a Memorandum of Understanding with the Geothermal Ground Source Heat Pump Consortium (GeoExchange). The ultimate objective is to facilitate installations of GeoExchange technology in any and all buildings where it is determined to be feasible and most cost-effective among energy-efficient technologies.

The State Department's first attempt to install Geothermal heat pump technology during the summer of 1998 at the Charleston Regional Center, South Carolina, looked promising. Unfortunately, total economic costs, the need for a hybrid system, and building design prevented implementation of this project.

\section{Energy Showcases}

The State Department has selected the National Foreign Affairs Training Center in Arlington, Virginia as its showcase facility. State is also applying for FY 2000 showcase designation for the Main State Building, due to the award-winning Electronic Relamping Project.

Designs were initiated or ongoing in FY 1998 for new office buildings in Tashkent and Berlin, Germany, and for housing in Shanghai, China, which are designated showcases.

\section{Training}

The State Department continues to have building management personnel trained through Association of Energy Engineers and FEMP curriculum courses.

\section{Funding}

Funding requests for energy conservation opportunities and capital equipment replacement are included in building management's normal budget submission. Projects are prioritized by their nature. Consideration is given to life-cycle cost effectiveness, condition of equipment, and savings-to-investment ratios.

In FY 1998, FBO obligated $\$ 3,181,781$ to overseas posts for implementation of a total of 396 conservation measures, which are expected to yield annual energy savings of approximately $\$ 760,956$.

\section{Energy Savings Performance Contracts}

The State Department has two ongoing, nearly completed energy savings performance contracts (ESPCs) at the Main State Building in Washington, DC, and the Beltsville Information Management Center (BIMC) in Beltsville, Maryland. Additional projects planned for the BIMC in FY 1999 include the installation of electronic drives for multiple pumping units. Also, a cross connection between the two chilled water systems will increase energy efficiency. A geothermal heat pump system will be considered when the old building chiller is scheduled for replacement in FY 2000.

The State Department awarded its first overseas ESPC in July 1998 to upgrade lighting and HVAC controls in Mexico City, Mexico. This project has a contract value of $\$ 593,557$ and a contract term of nine years, with expected annual savings of $\$ 67,000$. Cumulative savings over the contract term will amount to $\$ 603,000$ and 6.6 million kilowatt-hours.

Another ESPC is being negotiated for the installation of a natural gas fuel cell power plant at the Carl Schurz Siedlung residential complex in Frankfurt, Germany, during 1999. Other ESPC initiatives under consideration for FY 1999 and FY 2000 include projects in:

- New Dehli and Mumbai, India;

- Tokyo, Japan; and,

- Santo Domingo, Dominican Republic. 
The State Department intends to set up worldwide or regional ESPCs through Basic Ordering Agreements. Implementing ESPCs should become faster and easier once these regional hubs are in place.

An ESPC procurement is planned for the National Foreign Affairs Training Center, that will include renewable energy technology if practicable, and possibly a new lighting technology incorporating a microwave energy source.

\section{Utility Partnerships}

The State Department's first potential energy savings agreement (ESA) contract originated from GSA's Chiller Replacement Program in the Washington Metro Area. The Main State Building is scheduled for a total modernization by GSA with construction on Phase $1 \mathrm{~A} 1$, the building HVAC plant, in FY 2000. Potomac Electric Power Company (PEPCO) sought the opportunity to bid on the project in advance of the scheduled renovation.

The scope of the project included replacement of the building chillers and associated pumps and motors of the HVAC plant, an energy management and control system, replacement of the steam station and associated valves, and replacement of the cooling tower with a winterized cell tower. Unfortunately, the project was shelved due to an excessive life-cycle cost of 27.1 years.

\section{Vehicles}

In addition to a 90 percent alternative-fuel vehicle, compressed natural gas (AFV-CNG) auto acquisition plan, the State Department has embarked upon an ambitious AFV-CNG shuttle bus fleet acquisition plan. State purchased its first $\mathrm{CNG}$ coach from Bluebird, Inc., through GSA. State plans to have an entire AFVCNG shuttle bus fleet by 2002 , completely phasing out all diesel use.

\section{Environmental Activities}

The State Department is scheduled to have non-CFC refrigeration units installed by GSA in FY 1999 and FY 2000 in conjunction with the first phase of the Main State Building's modernization.

The State Department has one of the most successful recycling programs in the Washington Metro area. The Department recycles paper, cardboard, glass, aluminum and steel cans, construction debris, toner cartridges, light ballasts, fluorescent tubes, oils, solvents, and paints.

State takes advantage of DOE's Buying Energy-Efficient Products program (BEEP). Building managers in each domestic facility support the ${ }_{E}{ }_{E}$ segment of the program and procure new energy-efficient products.

The State Department will continue to submit deserving cases to DOE for consideration in the annual Federal Energy Efficiency Awards program.

In February 1998, the State Department issued two worldwide telegrams emphasizing energy conservation and opportunities for awards. FBO regularly publishes articles on energy conservation in the Maintenance Matters newsletter, which is distributed to posts worldwide.

Energy Management Contact

Mr. Richard T. Arthurs

Energy Manager

Facilities Management and Support Services

Department of State

A/OPR/FMSS

2201 C Street, NW

Washington, DC 20520

Phone: 202-647-8970

Fax: 202-647-1873 


\section{DEPARTMENT OF TRANSPORTATION (DOT)}

\section{Energy Efficiency Performance and Implementation Strategies}

During FY 1998, the Department of Transportation reported a 22.3 percent reduction in buildings consumption in Btu per gross square foot compared to FY 1985.

\section{DOT Performance Toward Buildings Energy Reduction Goals}

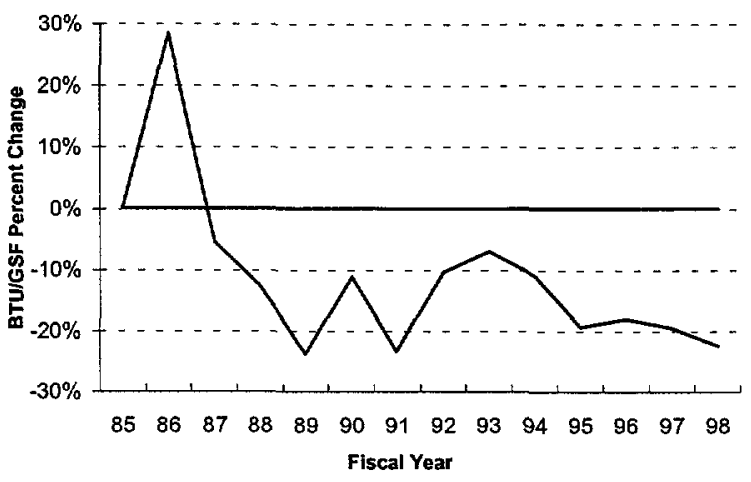

DOT Buildings Energy Use and Costs, FY98

$\begin{array}{lrr} & \text { BBtu } & \text { \$(Thou.) } \\ \text { Electricity } & 2,031.0 & 43,023.3 \\ \text { Fuel Oil } & 782.0 & 4,223.2 \\ \text { Natural Gas } & 806.6 & 5,006.8 \\ \text { Propane } & 34.8 & 339.5 \\ \text { Purchased Steam } & 13.4 & 181.6 \\ & & \\ \text { Total } & 3,667.9 & 52,774.4\end{array}$

The seven operating administrations (OAs) that operate facilities and the Transportation Administrative Service Center (TASC) all have active energy and water efficiency programs. In FY 1995, each OA developed an audit plan based on a prioritization review. These 10year audit plans were consolidated by the Office of the Secretary into a master audit plan. The OAs are now working with this plan.

Some notable energy surveys and energy conservation measures were completed in FY 1998, including:

- The Federal Aviation Administration (FAA) completed 18 audits. Approximately 68 energy conservation measures (ECMs) were investigated for cost and payback period. Total ECM backlog is currently about $\$ 6$ million. Lighting upgrades and air conditioning chiller upgrades are the most frequently occurring ECMs noted during energy audits. The FAA also conducted reviews of its utility bills and uncovered more than $\$ 550,000$ in overcharges and billing errors.

- The Federal Highways Administration (FHWA) continued its $\$ 6.5$ million renovation of the Fairbanks Building in McLean, Virginia. Renovations include a new variable air volume HVAC system, new low-pressure boilers, efficient lighting, new windows and doors, and roof insulation.

- The Maritime Administration (MARAD) has continued to make efficiency improvements at the Merchant Marine Academy (MMA) in King's Point, New York. New roofs, doors, and windows were installed in several buildings.

- The U.S. Coast Guard (USCG) completed SAVEnergy audits at many of its facilities. Audits have been completed at eight major facilities representing approximately 62 percent of USCG space. These audits identified more than $\$ 12$ million in projects that, when implemented, would save around \$3 million annually. USCG currently has a $\$ 3.5$ million project backlog.

Operation and maintenance $(\mathrm{O} \& \mathrm{M})$ procedures are decentralized within DOT. Basic procedures at facilities include securing HVAC equipment, unnecessary lighting, and office equipment during unoccupied hours. The FAA reduced airport and runway lighting when it did not compromise safety of aircraft operations. Normally, O\&M improvements are implemented without delay if the cost is $\$ 5,000$ or less. The use of energy management systems, such as the one installed at the Mike Monroney Aeronautical Center (MMAC) in Oklahoma City, Oklahoma, also help reduce consumption and demand.

USCG is continuing efforts to secure approval for a 280-unit solar hot water project for residential units in Hawaii. Financial and technical support for this effort is being provided by DOE and the National Renewable Energy Laboratory.

FAA's Southwest Region installed photovoltaic power panels at 16 remote communications locations during FY 1998, and additional installations are planned for FY 1999. 


\section{Energy Showcases}

USCG is actively engaged in the development of eight ENERGY STAR@ buildings that will become showcase buildings once projects have been completed. Energy improvements made in the DOT headquarters building (designated a showcase in 1995) help avoid \$1 million in costs annually.

\section{Training}

USCG conducted an energy training workshop in Milwaukee, Wisconsin, in March 1998 that was attended by 50 facility engineers. The workshop included an overview of the USCG facilities energy program and a formal training session on direct digital controls. Twenty-eight USCG and approximately 10 FAA personnel attended the FEMP Energy ' 98 conference in Bellevue, Washington, and several USCG and FAA staff made presentations. Thirty-seven FAA employees received training on FAA's revised Energy Management Reporting System.

\section{Funding}

DOT has had to leverage funding to accomplish surveys and audits. The USCG and FAA have both used the DOE FEMP SAVEnergy program and utility company incentive programs, as well as in-house staff to perform surveys.

\section{Energy Savings Performance Contracts}

Four energy savings performance contracts (ESPCs) were awarded during FY 1998:

- The Research and Special Programs Administration awarded an ESPC to install an energy management system and new lighting at its Cambridge, Massachusetts, research facility.

- USCG awarded an ESPC delivery order in Kodiak, Alaska, under the DOE Western region Super ESPC.

- FAA also awarded an ESPC delivery order for a lighting retrofit at its Seattle, Washington, Air Route Traffic Control Center.

- USCG awarded an ESPC for energy improvements at the USCG Academy through the Corps of Engineers in Huntsville, Alabama.
USCG has offered its Air Station Cape Cod and Support Center Elizabeth City as pilot ESPC sites for the development of DOE's Northeastern and Mid-Atlantic Super ESPCs. FAA's MMAC has prepared a Request for Proposal for various air handlers and control improvements, but these have been placed on hold by the contracting officer.

There is minimal current monetary savings from these ESPCs because most of the savings are paid to the contractor to shorten the term of the contracts. Annual cost savings after the term of the contract will be in excess of $\$ 650,000$, and annual energy savings from the four contracts is estimated at $54,000 \mathrm{MMBtu}$. As savings are realized from ESPCs they will be reinvested in new energy projects.

\section{Utility Partnerships}

FAA's MMAC has entered into a third-party natural gas purchase contract that has resulted in saving $\$ 138,000$ for the initial contract period.

\section{Environmental Activities}

The Assistant Secretary for Administration signed the Energy Efficiency and Resource Conservation Challenge. FAA has provided each of its energy managers, purchasing agents, and contracting officers with the DOE FEMP publication Buying Energy Efficient Products.

Each personnel office and OA primary energy manager has been advised of the requirement for energy and water efficiency being included in performance evaluations. FAA has established an energy and water conservation category within their Environmental Excellence Award Program. USCG has developed a similar incentive program. The OAs are also strongly encouraged to nominate employees for the annual Federal Energy and Water Management Awards.

\section{Energy Management Contact}

Mr. George Kuehn

Administrative Services Policy Division

U.S. Department of Transportation

Room 2318, Mail Code M43

$4007^{\text {th }}$ Street, SW

Washington, DC 20590

Phone: 202-366-1614

Fax: 202-493-2006 


\section{DEPARTMENT OF THE TREASURY (TRSY)}

\section{Energy Efficiency Performance and Implementation Strategies}

During FY 1998, the Department of the Treasury reported a 36.1 percent increase in buildings consumption in Btu per gross square foot compared to FY 1985.

\section{Treasury Performance Toward Buildings Energy Reduction Goals}

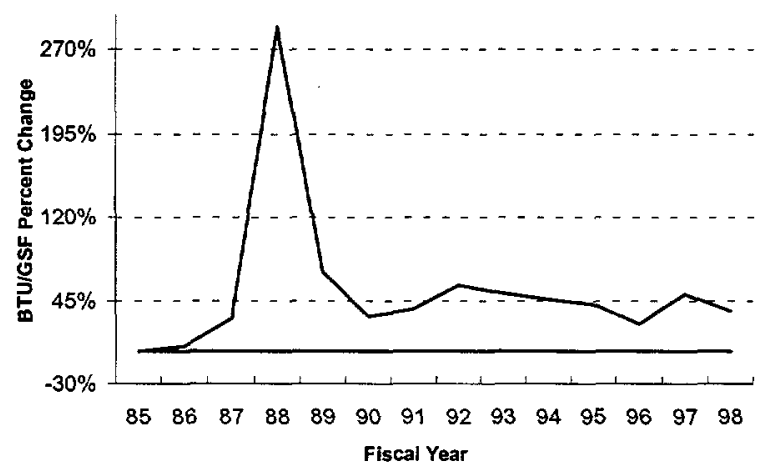

Treasury Buildings Energy Use and Costs, FY98

$\begin{array}{lrr} & \text { BBtu } & \text { \$(Thou.) } \\ \text { Electricity } & 1,162.9 & 23,896.6 \\ \text { Fuel Oil } & 41.4 & 170.9 \\ \text { Natural Gas } & 478.5 & 1,874.9 \\ \text { Propane } & 3.4 & 27.9 \\ \text { Purchased Steam } & 55.0 & 823.7 \\ & & \\ \text { Total } & 1,741.2 & 26,794.0\end{array}$

The Treasury Department's energy management program is implemented at the Bureau level. Treasury is committed to meeting the 30 percent reduction goal at non-industrial facilities by 2005 . However, over the next two years, the Bureau of the Mint will have a significant increase ( 23 percent) in energy consumption due to the Commemorative Quarter Program.

The following are energy and water saving projects performed during FY 1998:

- The Internal Revenue Service's (IRS) Andover Service Center continued its upgrade program with their three chillers being interconnected allowing for better load management, saving approximately $\$ 50,000$ and 600 megawatt-hours annually. A Unisys mainframe and related air conditioning was also removed for a 1,700 megawatt-hour and $\$ 175,000$ annual savings.

- GSA has initiated a major renovation of the IRS Headquarters in Washington, DC. This includes chiller, motor, and lighting replacement expected to result in $\$ 192,000$ in annual savings.

- The Cincinnati Service Center installed a new UPS system which will decrease the cooling load by 80 tons.

- The Financial Management Services (FMS) installed automatic valves on faucets and urinals in the Liberty Loan Building. FMS is also working with GSA and PEPCO to develop a building-wide lighting upgrade. At the Birmingham, Alabama Regional Financial Center GSA completed a major renovation including lighting, building envelope, and HVAC upgrades.

- The Federal Law Enforcement Training Center (FLETC) in Glynco, Georgia completed renovation of an 80,000 square-foot dormitory, including lighting, insulation, window, and HVAC upgrades.

\section{Training}

Treasury makes significant use of training courses offered by DOE. During FY 1998, Treasury sent 11 employees to energy management training courses at a cost of $\$ 36,500$. DOE FEMP courses were used whenever possible due to their low cost and high quality.

\section{Funding}

Overall, Treasury bureaus spent $\$ 328,000$ to install energy and water conservation measures during FY 1998. This figure does not reflect GSA's expenditures in buildings delegated to Treasury. Anticipated savings from the FY 1998 investments total $\$ 114,000$ per year.

The bureaus plan to spend \$1.8 million in FY 1999 . The bulk of this spending will be at the Main Treasury building, IRS, and Mint facilities.

\section{Energy Savings Performance Contracts}

Treasury bureaus implemented their first two energy savings performance contracts (ESPCs) in FY 1997.

In FY 1998, the Bureau of the Mint implemented two ESPCs at the Denver, Colorado and San Francisco, 
California Mints. The contracts totaling $\$ 1.688$ million will install energy efficiency measures including lighting retrofits, chiller replacements, HVAC upgrades, and upgrading the compressed air system. Anticipated annual savings are $\$ 192,300$ and 1,474 megawatt-hours. Additionally, the San Francisco project will save more than 1 million gallons of water annually. Installation will be completed early in FY 1999.

The U.S. Secret Service has proposed a second ESPC for their Beltsville, Maryland training facility. The ESPC with Baltimore Gas and Electric will cover a lighting retrofit in all buildings and day lighting in five buildings. Annual savings are expected to total $\$ 100,000$.

The Bureau of Engraving and Printing is discussing possible development of an ESPC with PEPCO. The U.S. Customs Service has also identified nine large residential units for possible use of ESPCs.

\section{Utility Partnerships}

The IRS's Andover Service Center entered into GSA's area-wide contract in accordance with the deregulation of utilities in Massachusetts. This will save $\$ 100,000$ per year.

FLETC, working with GSA, negotiated a new utility contract with Georgia Power. The new plan reduces the number of meters read by the utility from 124 to 5 . FLETC bought out the old meters for $\$ 361,000$ and expects the new rate structure to deliver annual savings of $\$ 460,000$ from reduced demand charges.

\section{Vehicles}

The bureaus have implemented driver awareness programs aimed at getting employees to drive in the most fuel-efficient manner possible. Bureaus continue to eliminate vehicles whenever possible, and request the smallest class of vehicle which will still accommodate the mission.
Treasury is developing a telecommuting policy which will allow for work from home, at satellite facilities, and hotels.

Treasury continues to slowly expand its alternative fueled vehicle fleet. The Bureau of Alcohol, Tobacco, and Firearms has reached 9 percent of its covered fleet acquisitions. Most of the treasury fleet is exempt from this requirement due to its law enforcement mission.

\section{Environmental Activities}

Treasury is committed to purchasing products in the top 25 percent of energy efficiency. Copies of the DOE "Energy Efficient Product Guide" have been provided to energy management and procurement personnel. All computers, monitors, printers and copiers purchased are ENERGY STAR $®$ compliant.

CFCs removed from old equipment are recovered and turned over to the Defense Logistic Agency CFC bank. Several Bureaus are now specifying the new low mercury lamps in all purchases, thereby reducing the amount of hazardous waste generated at their facilities.

\section{Energy Management Contact}

Mr. Bill McGovern

Environment and Energy Programs Officer

Department of the Treasury

1310 G-400 West

1500 Pennsylvania Avenue, NW

Washington, DC 20220

Phone: (202) 622-0043

Fax: (202) 622-1468 


\section{DEPARTMENT OF VETERANS AFFAIRS (VA)}

Energy Efficiency Performance and Implementation Strategies

During FY 1998, the Department of Veterans Affairs reported a 14.2 percent reduction in buildings consumption in Btu per gross square foot compared to FY 1985.

VA Performance Toward Buildings Energy Reduction Goals

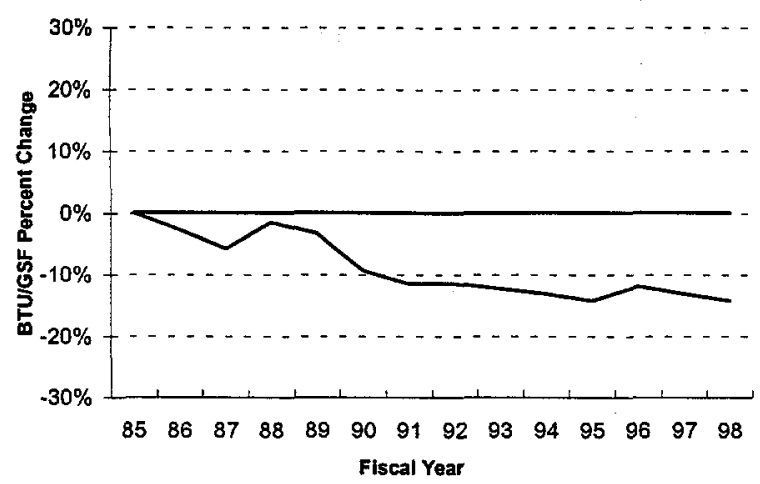

VA Buildings Energy Use and Costs, FY98

$\begin{array}{lrr} & \text { BBtu } & \text { \$ (Thou.) } \\ \text { Electricity } & 9,258.0 & 164,516.4 \\ \text { Fuel Oil } & 950.9 & 3,831.5 \\ \text { Natural Gas } & 14,502.2 & 52,031.2 \\ \text { Propane } & 3.6 & 28.9 \\ \text { Coal } & 147.1 & 149.6 \\ \text { Purchased Steam } & 1,193.0 & 9,723.6 \\ \text { Other } & 162.0 & 638.7 \\ & & \\ \text { Total } & 26,216.9 & 230,919.9\end{array}$

In order to meet the requirements of NECPA, EPACT, and Executive Order 12902, the Department of Veterans Affairs developed a 13-year plan for FY 1993 to FY 2005.

Building retrofit projects underway at VA facilities include the installation of state-of-the-art energy management control systems, modifications of existing HVAC systems, steam trap replacement, improvement of boilers and power systems, retrofitting lighting fixtures, installation of additional insulation and storm windows, and water conservation projects.

\section{Training}

During FY 1998, many medical centers took advantage of training classes offered by the Association of Energy Engineers in cooperation with DOE.
Funding

VA's funding for energy conservation retrofits and capital improvements was approximately $\$ 11.7$ million for FY 1998. Plans call for funding cost effective projects that have been approved by Veterans Integrated Service Network (VISN) Directors for accomplishment at the medical centers for FY 1999.

\section{Energy Savings Performance Contracts}

Since its first experience with energy savings performance contracts (ESPCs) in 1993, VA has issued a Final Boilerplate to all VA medical centers. The following projects were completed in FY 1997:

- VA Medical Center, Lake City, Florida, completed the retrofit of lighting fixtures throughout the facility;

- VA Medical Center, Dallas, Texas, installed a thermal water storage systems;

- VA Medical Center, Richmond, Virginia completed the installation of cooling towers; and

- VA Medical Center, Portland, Oregon, retrofitted approximately 10,000 lighting fixtures, 500 exit signs, and 800 occupancy sensors.

In 1998, almost all VISNs considered the possibility of using ESPCs and are planning to sign or have already signed a Memorandum of Agreement either with the U.S. Army Engineering and Support Center, Huntsville, Alabama, or DOE for the various services they offer under their ESPC programs. The following facilities have progressed in implementation efforts and have decided the ESPC method they are planning to use:

- Station-level contracts: 18 facilities

- DOE-based contracts: 16 facilities

- DOD-based contracts: 36 facilities

- GSA areawide-based contracts: 9 facilities

\section{Energy Management Contact}

Mr. Rajinder P. Garg

Chief, Energy Management Division (138C1)

U.S. Department of Veterans Affairs

810 Vermont Avenue, NW

Washington, DC 20420

Phone: 202-273-5843

Fax: 202-273-6298 


\section{ENVIRONMENTAL PROTECTION AGENCY (EPA)}

\section{Energy Efficiency Performance and Implementation Strategies}

In FY 1998, the Environmental Protection Agency reported a decrease in buildings energy of 11.0 percent in Btu per gross square foot compared to FY 1985.

\section{EPA Performance Toward Buildings Energy Reduction Goals}

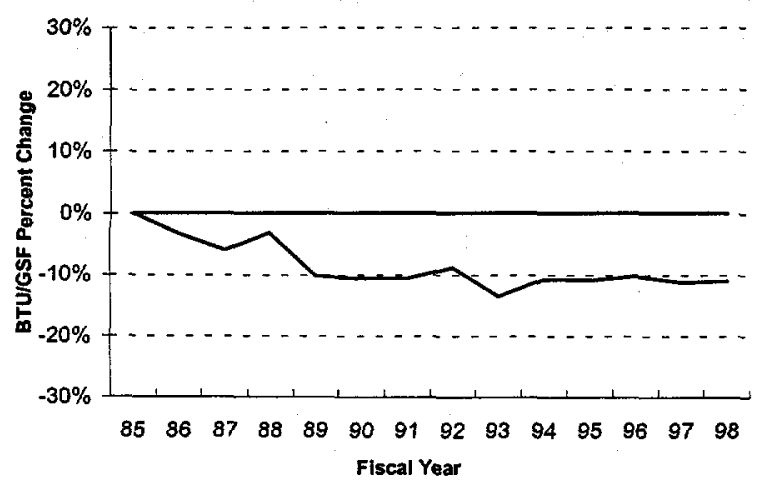

EPA Buildings Energy Use and Costs, FY98

$\begin{array}{lrr} & \text { BBtu } & \text { \$(Thou.) } \\ \text { Electricity } & 434.6 & 6,799.3 \\ \text { Fuel Oil } & 9.1 & 41.4 \\ \text { Natural Gas } & 533.5 & 2,223.6 \\ \text { Propane } & 0.6 & 8.1 \\ \text { Purchased Steam } & 45.2 & 417.0 \\ & & \\ \text { Total } & 1,022.9 & 9,489.4\end{array}$

The main objective of EPA's Energy and Water Conservation Program is to effectively and efficiently use natural resources when designing, constructing, and maintaining EPA facilities and facility systems.

While implementing its energy program, EPA has learned that its largest energy conservation opportunity is within the HVAC system of its laboratories. Due to energy-intensive health and safety requirements for onepass air for a laboratory, EPA's energy consumption is extraordinarily high. To address this, EPA is aggressively pursuing energy-efficient upgrades at several of its laboratories.

Descriptions of projects worked on during FY 1998 follow:
- Duluth, Minnesota. An energy management and control system has been installed. Two large boilers will be replaced with 10 smaller boilers to improve load efficiency.

- Gulf Breeze, Florida. A contract has been awarded to install Nodal Direct Digital Controls which will minimize energy waste, and monitor building security, fire protection, and indoor environmental quality. Timers were installed on approximately 20 electric water heaters.

- Edison, New Jersey. A combination desiccant wheel/heat transfer wheel system has been installed as a pilot program to recover energy from fume hood exhausts and to control humidity and conditioning in analytical chemistry laboratory modules.

- Houston, Texas. The air system was modified and an existing DDC system was upgraded. The facility incorporated a cooling tower condensate return system to reduce water consumption and operating costs, and enhance environmental conditions. The use of a night setback system is being incorporated to control exhaust fans, laboratory fume hoods, and supply air.

- Cincinnati, Ohio. Projects included a closed loop glycol cooling tower, energy-efficient electric chillers, energy-efficient elevator motors, boiler controls, building envelope modifications, adding a new HVAC system, Green Lights, and a new energy-efficient boiler.

- Ann Arbor, Michigan. In addition to the ESPC discussed below, NVFEL installed a photovoltaic energized active daylighting system to provide natural lighting in a hi-bay area. NVFEL's energy conservation efforts in FY 1998 saved \$45,000 in utility bill costs, which the facility used to purchase two pieces of equipment. The first, a $\$ 32,000$ vehicle mover allows an operator to maneuver test vehicles without starting their engines. The second was a $\$ 13,000$ fuel flow measurement system.

- New EPA Headquarters, Washington, DC. Many energy-efficient HVAC and lighting features have been incorporated into the design of the new headquarters. These include space-adjustable thermostat-controlled variable air volume fans, an 
upgraded HVAC system, and high-efficiency lighting controlled by workspace and floor motion sensors.

EPA recognizes that renewable energy sources and technologies are the most environmentally beneficial method of reducing facility energy consumption. EPA is including a requirement that renewable technologies be installed as part of facility upgrades in all ESPCs. Renewable opportunities include:

- Ft. Meade, Maryland. EPA, DOE and DOD have assembled a public-private partnership to potentially demonstrate the world's first megawatt class solid oxide fuel cell power station at EPA's new Fort Meade Environmental Science Center. Westinghouse Corporation, Baltimore Gas and Electric, and the Electric Power Research Institute are also involved.

- Athens, Georgia. A biomass feasibility study has been completed with the help of DOE, Tennessee Valley Authority, USDA, University of Georgia, and Georgia State Forestry. Preliminary results indicate biofuel could be obtained from materials currently disposed of in landfills. The next project phase will determine what equipment is suited to the Athens laboratory. Also, a solar hot water heater was installed at the on-site day care center.

- Gulf Breeze, Florida. EPA and the National Renewable Energy Laboratory (NREL) have jointly funded and awarded a photovoltaic system to generate on-site electricity to light the facility's piers.

- Edison, New Jersey. Three solar hot water heating systems are now the primary source of hot water in their respective facility areas. So far, this technology has resulted in savings significantly higher than expected.

- Manchester, Washington. EPA and NREL have jointly funded a demonstration photovoltaic project.

- Golden, Colorado. EPA and NREL are considering various solar technologies for a newly constructed leased facility.

Training

EPA participated in, and hosted numerous training events during FY 1998. Program staff regularly at- tended energy and water conservation conferences, seminars, and working groups. Engineers, architects, and facility management were encouraged to use proven innovative technologies. Contract staff who are certified trained energy managers briefed program staff periodically throughout the year on innovative technologies and design.

EPA's Office of Administration (OA) has instituted a semi-annual conference entitled "Laboratories for the $21^{\text {st }}$ Century" for agencies pursuing energy upgrades in Federal laboratories. EPA and DOE partnered in this effort. The first conference was held at the American Institute of Architects headquarters in Washington, DC in September 1997 and the second was held at Lawrence Berkeley National Laboratory (LBNL) in San Francisco, California in May 1998.

A third conference is scheduled for September 1999 in Cambridge, Massachusetts, and will be open to both Federal and non-Federal participants.

\section{Energy Savings Performance Contracts}

An ESPC to conduct a complete energy upgrade at the National Vehicle and Fuel Emissions Laboratory (NVFEL) in Ann Arbor, Michigan was awarded in Spring of FY 1998. Source emissions, energy consumption, and energy costs will all be reduced, renewable energy technologies will be installed, all while preserving the integrity of the laboratory's mission. The project will reduce NVFEL's energy consumption by 66 percent, lower energy costs by 74 percent, and reduce water consumption by 80 percent.

Based on the success of the NVFEL project, several other facilities have been targeted for upgrades using ESPCs and DOE's Super ESPCs:

- Ada, Oklahoma. The laboratory will undergo a comprehensive energy-efficiency upgrade of its chiller and boiler systems. A ground-source heat pump system will be installed, along with an integrated DDC system for energy, fire, and security management.

- Manchester, Washington. This facility is in the planning stage to be upgraded through DOE's Western Region Super ESPC. Contract award is expected during FY 1999.

- Duluth, Minnesota. This facility is in the planning stage to be upgraded using an ESPC during FY 1999. Geothermal heat pumps, wind turbines, and 
photovoltaics are among the technologies being investigated.

- Gulf Breeze, Florida. This facility is in the planning stage to be upgraded using DOE's Southeast Region Super ESPC. EPA has negotiated an Interagency Agreement with DOE to provide a nocost energy audit, in order to create the energy baseline model.

- Narragansett, Rhode Island. EPA is designing a HVAC system upgrade using high-efficiency chillers, geothermal heat pumps, and latent energy recovery technologies. This project will use the readily available heating and cooling potential of circulated bay water used for salt-water aquatic testing in the laboratory. The project will be pursued through DOE's Northeast Region Super ESPC. The request for proposals will require renewables.

- Las Vegas, Nevada. This facility is being reviewed for upgrade through an ESPC project.

- Richmond, California. This facility is in the planning stage for upgrade through DOE's Western Region Super ESPC. EPA is working with DOE, the NREL, LBNL, and the building owner to establish this as the first Federal leased facility ESPC.

- Athens, Georgia. This facility expects to utilize ESPCs for energy upgrades starting in FY 2000.

\section{Environmental Activities}

EPA has developed personnel performance standards to rate staff efforts toward achieving energy and water conservation program objectives-outstanding, satisfactory, and unsatisfactory. Implementation of these standards helps ensure that personnel will consider energy-efficient opportunities.

OA has a steering committee to organize EPA's integrated pollution prevention management program, that includes EPA energy and water conservation efforts.

EPA is committed to purchasing best-practice energyefficient and water-saving products that are in the upper 25 percent of all products in that category. EPA is also committed to purchasing emerging technologies and products that offer greater energy-efficiency, water savings, or use of renewable resources than products now commercially available.
EPA is committed to accelerating the acceptance of cleaner power alternatives and has established a pilot project at its Richmond, California facility. Once the project is complete, the EPA laboratory will run completely on green power. An aim of the project is to develop a procurement strategy for the purchase of green power that can be used as a prototype for other projects across the country. EPA will be the first government entity to implement the use of green power at one of its facilities.

EPA also plans to implement green power purchasing at its Athens, Georgia and Narragansett, Rhode Island facilities.

A series of energy awareness posters have been developed, illustrating energy-efficient HVAC systems, ESPCs, and pollution prevention. These posters are displayed at all EPA functions.

Through DOE's "You Have the Power" campaign, EPA identified and awarded 13 EPA employees as energy champions. Promotional materials were developed, including energy champion posters highlighting the EPA employees and their work; "Hometown Hero" newspaper articles describing their efforts; a large "You Have the Power" banner displayed at EPA headquarters for a month beginning on Earth Day, 1998; and an industry partnership advertisement issued in September 1998.

EPA continues to produce and distribute its quarterly newspaper, Greening EPA, formerly Conservation News. Articles in this newspaper provide the basis for facility managers to implement campaigns to conserve energy and at the same time inform the general public about EPA-specific conservation activities. EPA's Web site also offers a great opportunity to spread the energy and water conservation word, and includes the latest issue of Greening EPA.

\section{Energy Management Contact}

Mr. Philip Wirdzek

Facilities Management and Services Division

Mail Stop 3204

U.S. Environmental Protection Agency

$401 \mathrm{M}$ Street, SW

Washington, DC 20460

Phone: 202-260-2094

Fax: 202-401-8971 


\section{GENERAL SERVICES ADMINISTRATION (GSA)}

Energy Efficiency Performance and

Implementation Strategies

In FY 1998, GSA reported a 16.4 percent decrease in energy consumed in owned and leased buildings compared to FY 1985 in Btu per gross square foot.

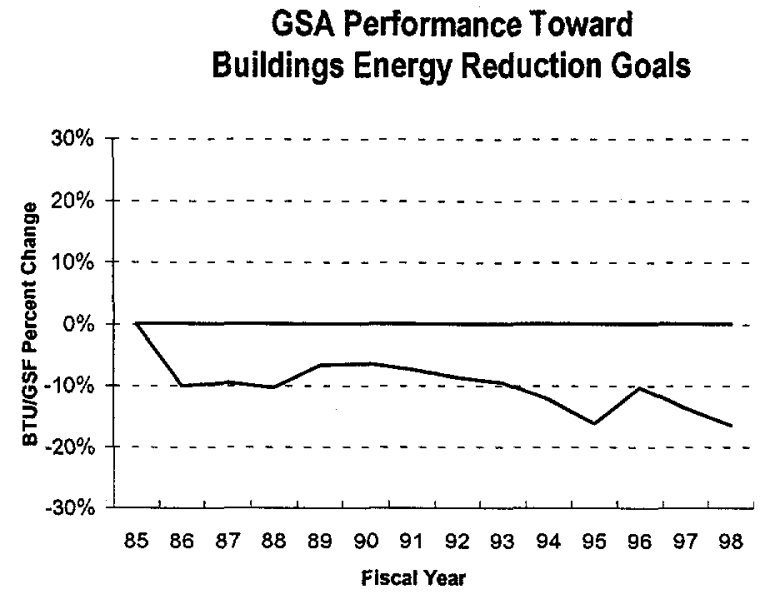

GSA Buildings Energy Use and Costs, FY98

$\begin{array}{lrr} & \text { BBtu } & \text { S (Thou.) } \\ \text { Electricity } & 8,684.2 & 183,995.0 \\ \text { Fuel Oil } & 54.8 & 236.4 \\ \text { Natural Gas } & 3,086.7 & 14,897.9 \\ \text { Purchased Steam } & 1,298.0 & 19,947.0 \\ & & \\ \text { Total } & 13,123.7 & 219,076.3\end{array}$

GSA has had an energy reduction plan since 1991. The plan was updated in 1998, which coincided with GSA's creation of an Energy Center Of Expertise and reflects the new approved business plan. The National Energy Center will reduce utility costs by promoting optimal energy use while protecting the environment and ensuring a quality workspace for GSA clients.

The Energy Center will have approximately 25 staff, plus regional associates. There are five people in Kansas City, Missouri; seven in the Public Utilities Center in Washington, DC; seven in the National Energy and Water Management Center in Fort Worth, Texas; and one or two regional associates in each of GSA's 11 regions.

The National Energy Center has several objectives:
- Optimize utility management and life-cycle costs and enhance building operations efficiency;

- Establish GSA as the Government's provider of choice for utility commodities and services;

- Encourage advocacy and partnering; and

- Provide leadership and promote energy efficiency and renewable energy.

In order to respond to the needs of Federal agencies, the Energy Center provides:

- Areawide contracts for the procurement of utilities and for acquisition of value-added services, such as utility financing of energy conservation projects;

- Aggregate purchasing of natural gas and electricity in deregulated markets;

- Energy use and analysis data; and

- Advocacy in the public policy arena to include renewable power sources as part of our energy portfolio.

Energy surveys are performed in accordance with GSA's 10-year audit plan. Some are obtained at no cost from utilities, some are obtained through DOE's SAVEnergy audit program, and the rest are funded by GSA. Audits identify energy conservation opportunities, which are developed into energy conservation project proposals using life-cycle costing methodology. Project submissions are compiled into a database for ranking by savings-to-investment ratio.

GSA conducted approximately 78 audits during the year. As funding permits, GSA will implement all lifecycle cost-effective projects with a payback of 10 years or less.

GSA is currently testing ASHRAE's BACnet standard, an open communication protocol for building automated controls. These efforts will result in increased energy efficiency.

GSA did not deploy any renewable technologies during FY 1998, but has several projects scheduled for completion: 
- A 2-kilowatt photovoltaic unit on top of a security guard shack in Kansas City, Missouri;

- Multiple solar units in Boston, Massachusetts; and

- 32 hot water solar units measuring 40 square feet each on the Prince Kuhio Federal Building in Honolulu, Hawaii.

\section{Environmental Showcases}

In FY 1998, DOE provided the showcase facilities award to four GSA buildings:

- Hawthorne Federal Building, Hawthorne, California;

- Chet Holyfield Federal Building, Laguna Niguel, California;

- Tampa Federal Courthouse II, Tampa, Florida; and

- Alexander Hamilton Customs House, New York, New York.

For new construction in FY 1999, GSA expects to formally announce at least one showcase facility, the EPA regional headquarters building in Kansas City, Kansas.

\section{Training}

In FY 1998, GSA held seven workshops in partnership with Federal agencies and state governments. These included:

- An energy conservation, deregulation, and alternative financing workshop in New York, New York;

- An energy conservation, deregulation, and energy product trade show in Seattle, Washington;

- A fleet vehicle energy conservation workshop in Scottsdale, Arizona;

- An energy efficiency products/services workshop in Washington, DC;

- A Cool\$ense workshop in Kansas City, Kansas;

- An intertribal utility purchasing/aggregation workshop in Rapids City, South Dakota; and

- A utility aggregation workshop in Tampa, Florida.
GSA continues to train its own personnel in all aspects of energy and water management and conservation. GSA currently has 28 trained energy managers on staff. Routine training includes topics like industrial energy process and building analysis, ASHRAE 90.1, energy management techniques, and building life-cycle costing.

\section{Funding}

In FY 1998, there were no appropriations. This trend in underinvesting may result in GSA not meeting the energy reduction goals. GSA does not have any energy efficiency or water conservation projects under way in FY 1998 from specific appropriations. Due to severe budget limitations in the Federal buildings fund, GSA did not request such appropriations.

\section{Energy Savings Performance Contracts}

GSA's Regional Energy Coordinators identify energy conservation opportunities and ESPC opportunities. The Energy Center coordinates congressional notification, provides guidance and information of best practices, and promotes the use of ESPCs.

Two ESPCs are currently in place. In FY 1997, GSA awarded a $\$ 1.6$ million ESPC for new construction at the DeConcini Courthouse and Federal Building in Tucson, New Mexico. Also awarded was a chiller replacement ESPC at the Burton Federal Building in San Francisco, California, which will generate annual savings of $\$ 287,000$ and 5.0 billion Btu.

GSA anticipates using the DOE Super ESPCs as they become available in all 11 regions and when situations present this option as the best business decision among available financing options.

\section{Utility Partnerships}

In 1998, GSA used areawide utility contracts and basic ordering agreements to obtain utility financing of energy projects.

In Vermont, GSA awarded four utility-financed projects at U.S. Border Station facilities. These projects were small in scope, consisting of lighting retrofits. Total project costs were $\$ 4,872$, with expected annual savings of $\$ 3,735$ and 153.7 million Btu.

In GSA Region 4, a $\$ 200,726$ lighting retrofit was financed through the GSA areawide utility contract. Annual savings are $\$ 34,655$ and 1.9 billion Btu. 


\section{Environmental Activities}

In FY 1998, GSA launched a new environmental concept called Planet GSA, which calls attention to four key areas in which GSA already plays a significant role:

- Buying Green. GSA manages a recycling program for 643,000 Federal employees in 1,000 Federal buildings. GSA's procurement process is going paperless. GSA's Environmental Products Guide carries more than 3,000 products and services that are environmentally orientated.

- Building Green. GSA will implement sustainable design principles in designing, constructing, modernizing, and disposing of their buildings. In FY 1998, GSA funded experts to design the Denver Courthouse project to serve as a model for the sustainable building program.

- Driving Green. GSA has bought 18,500 alternative fuel vehicles (AFVs) for the nationwide Federal fleet. The Energy Policy Act of 1992 requires that within the largest cities in 1998, 50 percent of all new vehicles must use alternative fuel. In 1999, this is up to 75 percent. To help, GSA has waived lengthy justifications to upgrade from a compact sedan to a midsize AFV.

- Saving Green. GSA will follow the Energy Center of Expertise business plan that includes installing the most energy-efficient equipment to operate building systems. New lighting technologies and lighting-control strategies are being tested in New York and San Francisco; in Hawaii, GSA plans to use solar hot water heating; and in the Northeast, GSA has awarded a contract to provide "green" power for up to 5 percent of Federal needs.
The Foley Square Federal Building in New York City is the only Federal facility among 14 charter members in the ENERGY STAR® Buildings program of the EPA. Additionally, GSA completed a beta test of the ENERGY STAR ${ }^{\circledR}$ program and provided comments to EPA. GSA plans to use the program to determine the energy performance of its building inventory.

GSA continues to support procurement of energyefficient products, and mandates the purchase of ENERGY STAR $\otimes$ computers and office equipment. GSA is a signatory to and an active participant in the Federal Procurement Challenge.

GSA annually participates in the DOE Federal Energy and Water Management Awards program and will receive four awards at the November 1998 ceremony. Also, GSA internally honors each one of the DOE award recipients with a ceremony and monetary award.

\author{
Energy Management Contact \\ Mr. Mark Ewing \\ Chief, Energy Branch \\ General Services Administration, 6PNE \\ 1500 East Bannister Road \\ Kansas City, MO 64131-3088 \\ Phone: 816-823-2691 \\ Fax: 816-823-2696
}




\section{NATIONAL AERONAUTICS AND SPACE ADMINISTRATION (NASA)}

Energy Efficiency Performance and

Implementation Strategies

During FY 1998, the National Aeronautics and Space Administration reported a 26.0 percent reduction in buildings energy consumption in Btu per gross square foot compared to FY 1985.

\section{NASA Performance Toward Buildings Energy Reduction Goals}

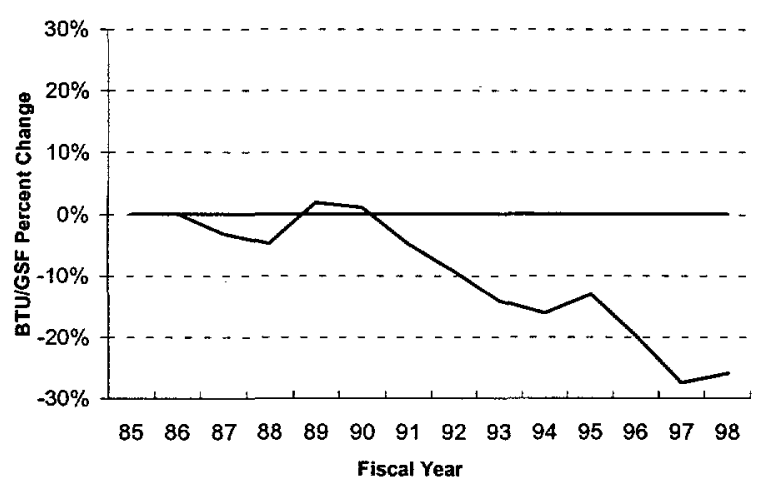

NASA Buildings Energy Use and Costs, FY98

$\begin{array}{lrr} & \text { BBtu } & \text { \$(Thou.) } \\ \text { Electricity } & 2,542.3 & 37,280.0 \\ \text { Fuel Oil } & 83.6 & 359.0 \\ \text { Natural Gas } & 1,243.9 & 4,505.0 \\ \text { Propane } & 9.8 & 125.0 \\ \text { Purchased Steam } & 61.7 & 904.0 \\ & & \\ \text { Total } & 3,941.4 & 43,173.0\end{array}$

NASA manages nine Centers, one Federally Funded Research and Development Center (FFRDC), and several Component Facilities and off-site program facilities from its Washington, DC, Headquarters.

NASA's mission-variable and industrial facilities, although exempt from NECPA requirements, are NASA's biggest energy consumers, representing more than 60 percent of total facility energy costs. For FY 1998, these facilities consumed 6,347.4 billion Btu, compared to 5,759.6 billion Btu in FY 1985. For this reason, NASA has established an internal goal to improve the energy efficiency of mission-variable buildings by 10 percent by FY 2000 compared to FY 1985 levels, where cost-effective and without adversely affecting mission performance.
During FY 1998, the following activities were undertaken at NASA facilities:

- Langley Research Center (LaRC) completed a major renovation of the National Transonic Facility that will significantly improve the operating efficiency of the facility, including installation of a new 135,000-horsepower variable-speed drive motor. Also, facilities serving the central compressed air utility system were consolidated, leading to the shutdown of the East Area Compressor Station.

- Through its Base Operations Support Services (BOSS) contract, Johnson Space Center (JSC) completed comprehensive energy and water conservation audits for all facilities at the main Center, Ellington Field, and the Sonny Carter Training Facility. JSC plans to implement the cost-effective energy and water conservation measures identified by the audits through ESPC contracts.

- Kennedy Space Center (KSC) completed a project to consolidate chilled water generation capacity. This project reduced energy consumption by replacing inefficient chillers that used CFCs with high-efficiency models and variable-speed chilled water pumping systems. Efficiency increased by 64 percent; energy savings attributed to this project are estimated at 21.8 billion Btu and $\$ 320,000$ per year. Maintenance expenses were also reduced by $\$ 300,000$ annually. KSC also completed 29 other energy projects totaling over $\$ 1.5$ million that will save $\$ 599,000$ annually.

- KSC continues to seek a reduction of overall potable water consumption. Efforts include installation of water saver kits for existing restroom flush valves and a biannual inspection of all main potable water distribution system components to verify proper operation and repair leaks. Cooling tower ozone treatment, which continues to produce water savings of 15 million gallons per year at the Launch Complex area and the Industrial Area Chiller Plant, has been supplemented with makeup water softening. This water conditioning measure will offset blowdown requirements, yielding an additional 16,000 gallons per day savings, or 5 million gallons per year. 
- The NASA Industrial Plant at Palmdale, California, completed two projects in Building 150 . The first replaced three inefficient $\mathrm{CFC}$ chillers with new chillers incorporating digital drives for energy conservation. The chilled water distribution system was also replaced with a primary/secondary chilled water system with variable-speed drives for each pump. The second project replaced 704 existing industrial fluorescent lighting fixtures with 155 energy-saving high-output, high-intensity-discharge metal halide fixtures. Together, these projects reduced annual energy costs by more than $\$ 100,000$.

- The Jet Propulsion Laboratory (JPL) continued its program to install waterless urinals throughout the Center. JPL also implemented two HVAC repair projects.

- Marshall Space Flight Center (MSFC) began construction of a multi-year $\$ 21$ million project to build a central chilled water facility. This will begin saving energy in FY 1999 and is expected to reduce energy and operations and maintenance costs by more than $\$ 1.8$ million annually.

- White Sands Test Facility (WSTF) installed lowflow urinals and lavatory fixtures in two administration facilities. Also started was the design and construction of evaporation ponds, which will displace approximately 1.2 million gallons of dilution water annually and save water pumping energy.

- Goddard Space Flight Center (GSFC) is using direct digital control (DDC) systems to turn off selected air handler motors between 7:00 PM and 5:00 AM on weekdays and all day on weekends. The air handlers run only if space temperatures rise above or fall below a given set point. This effort yielded GSFC's largest energy savings in nonmission variable buildings for FY 1998. GSFC also continued a multi-year project to replace its central chilled water distribution system. The second phase will be initiated in FY 1999. Also being replaced are GSFC's central steam and condensate systems, electric ovens and grills, and building curtain walls.

- Ames Research Center replaced about 1,000 incandescent bulbs with compact fluorescent lamps, saving 340,000 kilowatt-hours annually. Ames also replaced all on-site traffic signals with
LED units, saving 2,000 kilowatt-hours annually and virtually eliminating maintenance costs.

From FY 1991 through FY 1998, NASA completed energy audits for 70.2 percent of its total building square footage, including 72.4 percent of non-exempt square footage, and 67.9 percent of exempt and industrial square footage.

NASA, with the assistance of DOE's National Renewable Energy Laboratory (NREL), developed the Renewable Energy Technology Implementation Plan (RETIP), which identifies current renewable energy technology work under way at the Centers and organizes and coordinates the implementation of any potentially costeffective projects at all NASA Centers and Component Facilities.

NASA continued its partnership with NREL to develop implementation guidelines for increasing NASA's use of renewable energy technology. The guidance will be issued as a new NASA directive in FY 1999, along with revised guidance for implementing energy efficiency and water conservation measures.

Several NASA Centers are using renewable energy technologies on selected small-scale applications:

- JSC is using photovoltaics to power traffic caution signals and the emergency warning system. Also being tested is a photovoltaic-powered direct expansion air conditioning system.

- WSTE installed a photovoltaic solar power source to provide energy to a microwave repeater site, providing a communication link to the U.S. Army's White Sands Missile Range.

- KSC is using photovoltaic exterior lighting systems in selected applications, including security lighting at the Merritt Island Launch Area. These lighting systems have been found to generate a lighting spectrum that is preferable to high pressure sodium lighting in areas near sea turtle habitat. The KSC security organization deployed five photovoltaicpowered intrusion detection devices in remote locations at Cape Canaveral Air Station in preparation for the Cassini mission to Saturn. Solar battery charging systems are also planned for an Area Status and Control System for Fuel Storage Area \#1 at the Cape Canaveral Air Station. The photovoltaic panels will supply power for six traffic 
barrier arm devices, six traffic stanchions, and wireless signaling and control components.

- MSFC is evaluating five potential renewable energy projects including photovoltaic parking lot lighting, ground source heat pumps, solar process water pre-heating, solar pre-heating of make-up air, and ambient light sensors.

\section{Energy Showcases}

The Marshall Space Flight Center Project Engineering Facility, Building 4203, was designated as NASA's showcase facility. The facility features many state-ofthe-art energy efficiency and environmental quality measures, such as tinted windows, a variable air volume HVAC system, HCFC-123 chillers, an automated energy management system with direct digital controls, self-illuminating exit signs, and a radon venting system. The building is heated with steam from the Army's Redstone Arsenal steam distribution system, which is connected to the City of Huntsville's solid-waste-tosteam plant.

A NASA-funded comprehensive audit of the facility identified additional energy and water conservation measures, including lighting upgrades and occupancy sensors, high-efficiency motors, variable-frequency drives for the air handling units and chilled water pumping system, water-saving devices, and operations and maintenance recommendations. The water conservation measures, funded through the Federal Energy Efficiency Fund, should be completed by early FY 1998.

\section{Training}

In FY 1998, NASA energy managers attended numerous energy training courses offered by DOE FEMP as well as private organizations. The majority of NASA energy managers also attended the NASA Environmental Conference held in February 1998 in Cocoa Beach, Florida. The Conference featured several seminars on ESPCs, utility demand-side management programs, global climate change, and electric utility restructuring.

\section{Funding}

NASA-funded facilities energy conservation projects are divided into two categories. The first consists of minor capital improvement projects (under $\$ 200,000$ ) that can be achieved with Center funds. The second consists of major capital improvement projects (over $\$ 200,000)$ requiring Construction of Facilities (CoF) program funding. Energy conservation projects must compete with all other construction projects for $\mathrm{CoF}$ funding. Life-cycle costing is the primary tool for analyzing energy retrofit projects.

No CoF projects were implemented in FY 1998 for the sole purpose of energy or water conservation. However, many CoF projects do contain features that will conserve energy or water and reduce costs. Examples include HVAC system modernization, upgrade of energy monitoring and control systems, lighting and electrical system efficiency improvements, weatherization and other building envelope measures, and water conservation measures including conservation, recycling, and reuse projects.

It is not possible to accurately break out the cost of energy efficiency and water conservation measures from the overall budgeted amount for CoF discrete, repair, and rehabilitation and modification projects. The following estimate of FY 1998 and FY 1999 direct agency expenditures for energy efficiency and water conservation improvement projects and audits is based on data reported by the Centers and Component Facilities:

FY $98 \quad$ FY 99

Direct Agency Expenditures $\$ 13,813 \mathrm{~K} \quad \$ 13,695 \mathrm{~K}$

\section{Energy Savings Performance Contracts}

NASA has some limited experience with ESPCs:

- Michoud Assembly Facility (MAF), a Government-owned, contractor-operated facility, implemented an energy cost reduction program with Lockheed-Martin Marietta Space Systems (LMMSS) in 1988. Under this program, LMMSS' prime contract with NASA was modified to include an energy conservation incentive clause. The program rewards LMMSS for exceptional performance in the management of energy usage at MAF by providing 8 to 14 percent of energy savings achieved as an additional award fee. The program also includes provisions for sharing savings achieved through energy conservation projects proposed by LMMSS. The share of savings is determined by whether NASA or LMMSS funds the capital investment. In FY 1995, the ECRP was modified to include cost savings for contractor recovery of utility company overcharges and negotiation of lower utility rates.

- GSFC has established a multiple award indefinite delivery, indefinite quantity (IDIQ) ESPC with two Washington, $\mathrm{DC}$, area energy service companies 
(ESCOs). The contract vehicles were awarded in May 1998 , and each has a maximum value of $\$ 5$ million. They will provide for the installation of efficient lighting fixtures, LED exit signs, and other energysaving technologies at GSFC and Wallops Flight Facility. GSFC is in the process of negotiating delivery orders for two lighting retrofits that will be issued in early FY 1999.

The following NASA Centers and Component Facilities are actively pursuing ESPC projects:

- Ames Research Center has been approached by a DOE Western region Super ESPC ESCO with a proposal to reduce energy and related operations and maintenance costs at the Center. If accepted, the proposal could result in $\$ 2$ million in energy efficiency improvements to lighting, HVAC, energy management and control systems, and domestic hot water heating systems.

- $\mathrm{KSC}$ is working with DOE to include a minimum purchase project in the Southeast region Super ESPC. The project will provide energy-efficient lighting and HVAC system modifications for eight buildings. An ESCO has been selected and is in the process of developing the delivery order Request for Proposal (RFP). Energy savings are projected at more than 16 BBtu and $\$ 200,000$ annually. KSC is also working with the Air Force $45^{\text {th }}$ Space Wing to include NASA buildings in the scope of a new Air Force ESPC planned for Cape Canaveral Air Station.

- LeRC is working with DOE to include a minimum purchase project in the Midwest region Super ESPC. The project will include energy-efficient lighting and motors, steam distribution system improvements, and chilled water system modifications. LeRC is in the process of developing the RFP. Anticipated annual savings are $\$ 82,000$.

- JSC received contractor proposals for ESPC services through its BOSS contract. The proposals identified cost-effective energy and water conservation measures requiring investment of more than $\$ 20$ million, with annual savings in excess of $\$ 2.5$ million. JSC is working with DOE to implement the proposed ESPC projects through DOE's Central region Super ESPC contract.

\section{Utility Partnerships}

KSC issued a delivery order to Florida Power and Light (FPL) to finance and construct the LC-39 Emergency Generator Plant upgrade. The new plant will be used for emergency backup and peak shaving under FPL's Commercial/Industrial Load Control program. The project will be funded through electricity service rate savings, which are projected at $\$ 770,000$ annually. Also, a second study is under way to establish the feasibility of another utility incentive project with FPL to construct a thermal energy storage system at the Industrial Area Chiller Plant.

Dryden Flight Research Center is obtaining energy efficiency improvements for some buildings through the Edwards Air Force Base basic ordering agreement with Southern California Edison.

Lewis Research Center (LeRC) completed construction of a fueling station that is now operational. NASA invested $\$ 105,000$ for site preparation work. The East Ohio Gas Company provided the actual CNG fueling equipment. The project will potentially displace up to 77,000 gallons of gasoline annually.

NASA Centers received a total of $\$ 793,500$ in utility rebates during FY 1998. GSFC received $\$ 611,800$, Jet Propulsion Laboratory $\$ 107,000$, and KSC $\$ 74,700$. Several NASA Centers also received utility cost credits by voluntarily shedding electrical load or operating standby generation capacity when requested by their local utilities. GSFC received a $\$ 24,815$ credit from its electric utility for participating in one four-hour load curtailment event.

\section{Environmental Activities}

NASA Centers and Component Facilities are actively procuring energy-efficient goods and products that are life-cycle cost-effective. Procedures have also been adopted to procure ENERGY STAR@ computers whenever possible. In the past year KSC purchased more than 3,300 ENERGY STAR® computers. KSC's Base Operations Contractor maintains a listing of 69 energyefficient products that are available from the Center supply system.

JSC issued a Center Management Instruction, which mandates that all equipment purchased must follow procurement regulations outlined in Executive Order 12902, Section 507. JSC's BOSS contractor will institute mechanisms and set targets that will enhance energy-efficient procurement efforts. 
Both GSFC and the contractor operator of the NASA facilities at Santa Susana Field Laboratory have individually joined the EPA Green Lights program. NASA is reviewing its position on establishing an ENERGY STAR Buildings Program Partnership.

Most NASA Centers and Component Facilities include the successful implementation of energy management requirements in performance evaluations and positions descriptions for all those involved in energy management activities.

In FY 1998, NASA submitted four award nominations to the DOE Federal Energy and Water Management Awards program and received one award. KSC established the Energy Achievement Goals for Life and Environment (EAGLE) award program. During FY 1998, three employees received the EAGLE award. LaRC continued its Outstanding Energy Achievement Award program.
Lewis Research Center issued Operating Instructions entitled "Fluorescent Lighting Fixture Requirements" and "Occupancy Sensors" which requires the use of energy efficient lighting products when performing facilities work. These Instructions have also led to phasing out of older lighting products in the Center supply system with more energy efficient items.

Michoud Assembly Facility completed a major upgrade of desktop computers by purchasing 1,018 ENERGY STARß-compliant personal computers. This computer upgrade allowed about 600 computers that were not ENERGY STAR $®$-compliant to be taken out of service.

\author{
Energy Management Contact \\ Mr. Richard Wickman \\ Environmental Management Division (JE) \\ National Aeronautics and Space Administration \\ 300 E Street, SW \\ Washington, DC 20546-0001 \\ Phone: 202-358-1113 \\ Fax: 202-358-2861
}




\section{NATIONAL ARCHIVES AND RECORDS ADMINISTRATION (NARA)}

\section{Energy Efficiency Performance and Implementation Strategies}

The National Archives and Records Administration (NARA) owns and operates 12 separate facilities dedicated to the preservation, storage, display, and use of historical documents and artifacts. Because the stringent records storage requirements are very energyintensive and preclude major changes in operational parameters to conserve energy, all of the NARA facilities are excluded from the energy reduction requirements of the National Energy Conservation Policy Act (NECPA).

NARA's energy consumption figures from 1995 to 1998 show a considerable reduction in consumption and are a reflection of the implementation of NARA's Energy Plan. Examples of measures taken to reduce the energy consumption during this time period are:

- Participation in electrical companies' load curtailment programs;

- Load-shedding policies at individual facilities;

- Lamp and ballast replacement projects;

- LED exit light retrofit projects;

- Installation of variable frequency drives on laboratory AHUs to allow reduced airflow and energy load during off hours;

- ATC modifications made to reduce energy consumption;

- Operational modifications made to reduce energy consumption;

- Installation of lighting controls; and

- Replacement of existing equipment with new highefficiency equipment.
NARA's policy is to continue to maximize the operational efficiency of its buildings and minimize energy consumption. Items that are being planned for FY 1999 are:

- Continued implementation of energy conservation policies;

- Replacement of chillers at one of NARA's library facilities;

- Installation of new efficient doors and windows at one of NARA's library facilities; and

- Entering a joint energy purchasing agreement by one of NARA's library facilities with other Federal agencies in the area.

\section{Energy Showcases}

NARA is currently reviewing its facilities to determine if any qualify to be showcase facilities.

Energy Savings Performance Contracts

An energy audit and the negotiation of an ESPC was recently completed at one of the NARA facilities. The scoping and design of the work is in process.

\section{Environmental Activities}

NARA has an overall incentive award program that includes an award for exceptional performance in energy conservation.

\section{Energy Management Contact}

Mr. Patrick Alexander

Chief, Facilities Management Branch

NAFM Room 2320

National Archives and Records Administration

8601 Adelphi Road

College Park, MD 20740-6001

Phone: 301-713-6470 x231 


\section{NUCLEAR REGULATORY COMMISSION (NRC)}

Energy Efficiency Performance and

Implementation Strategies

In FY 1998, the Nuclear Regulatory Commission's (NRC) One White Flint North (OWFN) building reported a 1.5 percent increase in energy consumption compared to FY 1989, the first full year the building was occupied. Two White Flint North (TWFN) reported a 1.0 percent decrease compared to FY 1995 , the first full year the building was occupied.

NRC Buildings Energy Use and Costs, FY98

$\begin{array}{lrr} & \text { BBtu } & \text { \$(Thou.) } \\ \text { Electricity } & 85.0 & 1,823.0 \\ \text { Natural Gas } & 1.0 & 8.0 \\ \text { Total } & & \\ & 86.0 & 1,831.0\end{array}$

NRC's Energy Management Plan is updated annually to identify strategies to meet the energy reduction goals of NECPA and Executive Order 12795. The energy management strategies implemented for both the OWFN and TWFN buildings in FY 1998 are:

- Utilization of an automated energy management system to maximize energy efficiency of HVAC equipment;

- Implementation of an employee awareness program that includes cutting off lights when not in use;

- Utilization of HVAC free cooling using heat exchanger technology;

- Reduced chiller operations;

- Energy-efficient design technologies in construction and new space;

- Quality Assurance inspections and Quality Control to identify wasteful and/or good operating practices;

- Enhanced water treatment and filtering to enhance energy-efficient equipment operations;

- Utilization of water management and conservation technology; and
- Implementation of commercial facilities management contract requirements to conserve energy by prudent equipment operating procedures and maintenance.

In addition, occupancy sensors were used in the OWFN building to control interior lighting. Also, the TWFN building utilized comprehensive preventive maintenance practices to promote energy efficiency.

\section{Training}

NRC is an active participant in the Interagency Energy Management Task Force. Members have attended seminars, workshops, and conferences sponsored by the Task Force.

\section{Energy Savings Performance Contracts}

During FY 1998, NRC's Energy Management Plan was updated to include an initial screening test prepared by DOE to determine if either the OWFN or the TWFN building were good candidates for an ESPC. The results of the test indicated that both are candidates and that significant energy savings would be achieved.

\section{Utility Partnerships}

During FY 1998, both buildings participated in the Potomac Electric Power Company's (PEPCO) voluntary load curtailment program. Also, PEPCO's Engineering Design Group performed a preliminary audit of buildings to identify potential energy conservation projects, such as installation of electronic ballasts, high-efficiency exit signs, and lighting controls.

\section{Environmental Activities}

The building operation and maintenance contract specifications were updated to ensure that all building support replacement projects and components are energy-efficient.

Implementation of energy conservation projects are included as elements in the position descriptions and performance plans of NRC facility managers.

\section{Energy Management Contact}

Mr. Ken McDow

Division of Facilities and Security

Office of Administration

Nuclear Regulatory Commission

Washington, DC 20555-0001

Phone: $301-415-1712$ 


\section{RAILROAD RETIREMENT BOARD (RRB)}

Energy Efficiency Performance and

Implementation Strategies

In FY 1998, the Railroad Retirement Board (RRB) reported a decrease of 7.6 percent in Btu per gross square foot compared to FY 1986, their first full year of reporting.

\begin{tabular}{lcr}
\multicolumn{3}{c}{ RRB Buildings Energy Use and Costs, FY98 } \\
\multicolumn{4}{c}{ BBtu } & S (Thou.) \\
Electricity & 19.9 & 484.3 \\
Natural Gas & 19.5 & 86.1 \\
Total & 39.4 & 570.4
\end{tabular}

The headquarters building in Chicago, Illinois, is the only building over which the Railroad Retirement Board has operational control. RRB operates and maintains the building under a delegation of authority agreement with the General Services Administration (GSA).

RRB updated its energy conservation plan in March 1993 to incorporate the requirements of NECPA, Executive Order 12759, and EPACT.

$R R B$ has invested in energy-efficient equipment and items such as T-8 lamps, electronic ballasts, compact fluorescent bulbs, light sensors, air controllers, etc., which have helped reduce energy consumption. Also, RRB operating procedures have been refined further to achieve the maximum energy savings.

\section{Training}

This agency does not meet the definition of an executive department under section 101 of Title 5 and therefore is not subject to the energy management training provision of the Energy Policy Act (EPAct). However, personnel responsible for energy management will receive the additional training that is to be provided by the GSA under the EPAct requirements.

\section{Funding}

RRB utilizes building operation funding for energy conservation measures. Between $\$ 10,000$ and $\$ 20,000$ per year of building operating funds are available for such measures. GSA, as the Government owner of the RRB building, has the responsibility to fund projects over $\$ 50,000$ and has future projects planned but not funded.
Energy Savings Performance Contracts RRB has not entered into any ESPC contracts. The comparatively small size of potential contracts available to RRB - at a $\$ 50,000$ limit because of the delegation of authority agreement with GSA-is not practical for this type of procurement.

\section{Utility Partnerships}

RRB is developing partnership efforts with GSA Region 5. GSA intends to reduce Federal building energy costs by consolidating electrical usage and billing under a single contract. GSA advised it will issue a Request for Proposal on March 1, 1999, and award a contract effective October 1, 1999. Savings will come from combining agency loads and dealing with a single vendor.

Each agency will pay the contract price for electricity, which will be time-of-day and load-sensitive. GSA will provide assistance in purchasing the necessary meters. RRB has submitted its energy requirements to GSA for participation in this program.

\section{Environmental Activities}

New electric chillers installed by GSA utilize approved R-22 refrigerant. All obsolete fluorescent ballasts have been and will continue to be disposed of safely. Older CFC drinking fountains are being replaced with new energy-efficient, non-CFC refrigerant fountains.

RRB has developed procedures to ensure procurement of energy-efficient products whenever cost-effective.

\section{Energy Management Contact}

Mr. Henry M. Valiulis

Director of Supply and Service

U.S. Railroad Retirement Board

Room 1230

844 North Rush Street

Chicago, IL 60611

Phone: $312-751-4565$

Fax: 312-751-4923 


\section{SOCIAL SECURITY ADMINISTRATION (SSA)}

\author{
Energy Efficiency Performance and \\ Implementation Strategies
}

SSA Buildings Energy Use and Costs, FY98

$\begin{array}{lrr} & \text { BBtu } & \text { \$(Thou.) } \\ \text { Electricity } & 591.7 & 11,625.0 \\ \text { Fuel Oil } & 8.9 & 26.5 \\ \text { Natural Gas } & 120.5 & 673.2 \\ \text { Purchased Steam } & 32.0 & 389.0 \\ & & \\ \text { Total } & 753.1 & 12,713.7\end{array}$

To accomplish the requirements of EPAct and Executive Order 12902, SSA recently conducted comprehensive energy audits of its entire inventory of Federallyowned delegated space. Prior to FY 1998, SSA had audited only portions of this space. In FY 1998, the audit program was expanded; the following is a list of audits and energy projects initiated during FY 1998:

Audits:

- Northeast Program Service Center, New York, New York;

- Mid-Atlantic Program Service Center, Philadelphia, Pennsylvania;

- Wilkes-Barre Data Operations Center, WilkesBarre, Pennsylvania;

- Woodlawn Headquarters Complex, Woodlawn, Maryland;

- Western Program Service Center (WNSPC), Richmond, California; and

- Great Lakes Program Service Center, Chicago, Illinois.

The audits covered 90 percent of SSA's delegated space; the remaining 10 percent is leased.

Projects:

- Energy-efficient lighting and lighting controls, Supply Building, Woodlawn, Maryland; and

- Energy-efficient lighting, Operations Building, Woodlawn, Maryland.
These two lighting projects have a combined worth of $\$ 2.3$ million.

At the WNSPC SSA has initiated a project to use water from an underground stream for irrigation, gray water for flushing water closets, and make up water for cooling towers.

A 1996 audit identified $\$ 700,000$ in energy conservation projects for the National Computer Center (NCC). A new central heating/cooling plant is being installed through a design/build process. This new plant should provide $\$ 73,000$ in annual demand savings and the energy projects should save $\$ 271,000$, and more than 4.6 million kilowatt-hours, per year. Design began in June 1998 and construction was underway in the fall of 1997. Work is to be complete in January 1999.

When the energy projects initiated during FY 1998 are completed, SSA should save more than 11.6 million kilowatt-hours of electricity annually. This will avoid the production and emission of more than 24.8 million pounds of carbon dioxide, more than 100,000 pounds of sulfur dioxide, and 74,750 pounds of nitrogen oxides.

Solar lighting was installed at the NCC as a demonstration project. Day lighting was explored at several warehouses but was not economically feasible when compared to energy-efficient lighting technologies. However, daylighting is being incorporated into prospectus level renovations. SSA is also looking into using solar preheating of outdoor ventilation air and ground source heat pumps.

\section{Energy Showcases}

GSA has submitted, on behalf of SSA, a prospectus request to build a new standalone childcare facility at SSA Headquarters in Woodlawn, Maryland. SSA plans on designating this as a showcase to include solar preheat of fresh air, ground source heat pumps, passive solar design, and natural day lighting.

\section{Training}

Building managers and staff have attended a variety of training classes and conferences examining life-cycle cost analysis, alternative fuels, lighting, controls, and demand side management practices. SSA staff attends GSA regional conferences. 
Also in FY 1998, SSA staff participated in a DOE interactive training program with the aim of having a trained energy manager in each SSA delegated facility. SSA has scheduled additional training designed to help energy managers track energy usage and cost. All personnel responsible for tracking energy have been trained or will be trained by the end of FY 1999 in energy conservation.

\section{Funding}

In conjunction with GSA, SSA has completed or expects to complete in excess of $\$ 67$ million in renovations to its delegated buildings between FY 1997 and FY 2000. The vast majority of these renovations are GSA-funded prospectus level projects.

SSA has invested $\$ 2.3$ million of its own funds in energy-efficient lighting conversions during FY 1998. These renovations should yield $\$ 800,000$ in annual energy and maintenance savings.

\section{Energy Savings Performance Contracts}

SSA has not initiated any energy savings performance contracts (ESPCs) because many of the ideal candidate projects (primarily lighting) have either been accomplished or will be through prospectus work.

\section{Utility Partnerships}

GSA's areawide utility contracts include all SSA's delegated buildings, and SSA is designated as an ordering official on these contracts. SSA has used them to perform energy audits $(\$ 426,000)$ and lighting projects ( $\$ 2.3$ million).

\section{Environmental Activities}

SSA has reduced its stock of CFC equipment dramatically. In 1998, chillers at the NCC were removed and CFC-free equipment was installed. At the conclusion of this contract, 8 out of SSA's 13 central plants will be CFC compliant. One of the remaining three should be converted during FY 2000.

It is SSA's routine practice to recycle both lamps and ballasts. This requirement has been incorporated into SSA contracts.

SSA awards employees whose job descriptions require energy management skills and whose overall performance or individual acts are exceptional. SSA also recognizes individual contributions to energy savings through on-the-spot and suggestion awards programs.

\section{Energy Management Contact}

Mr. Ed Harmon

Office of Realty Management

Social Security Administration

1-B-25 Operations Building

6401 Security Boulevard

Baltimore, MD 21235

Phone: 410-965-4989

Fax: 410-966-0668 


\section{TENNESSEE VALLEY AUTHORITY (TVA)}

Energy Efficiency Performance and

Implementation Strategies

During FY 1998, the Tennessee Valley Authority reported a 18 percent decrease in energy consumption in Btu per gross square foot compared to FY 1985.

TVA Performance Toward Buildings Energy Reduction Goals

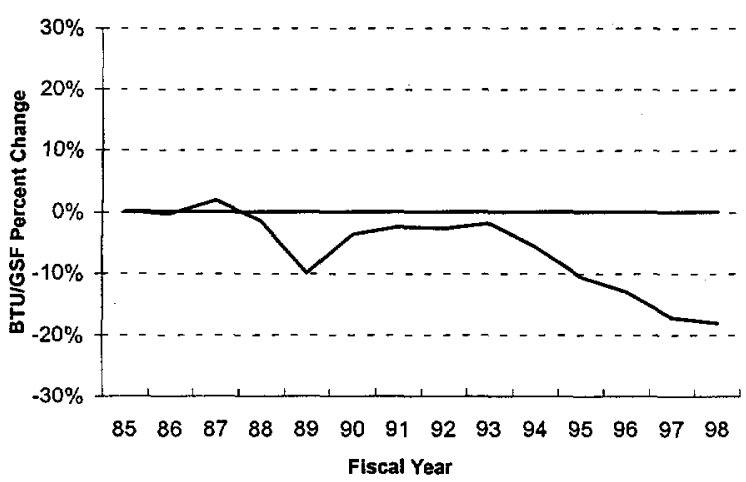

TVA Buildings Energy Use and Costs, FY98

$\begin{array}{lrr} & \text { BBtu } & \text { \$ (Thou.) } \\ \text { Electricity } & 650.8 & 8,488.1 \\ \text { Fuel Oil } & 3.0 & 20.4 \\ \text { Natural Gas } & 4.6 & 43.9 \\ \text { Total } & & \\ & 658.4 & 8,552.4\end{array}$

TVA's Energy Plan ensures the efficient use of energy in the operation, maintenance, and design of TVA buildings and facilities. During FY 1998, TVA implemented energy conservation opportunities (ECOs) costing \$1.46 million with a potential annual savings of more than $\$ 740,000$. This is an average payback of 1.96 years.

To meet the challenge of surveying more buildings, the DOE Facility Energy Decision System (FEDS) building energy analysis program is being used to identify and evaluate potential ECOs. Cost effective ECOs are identified through the FEDS software, allowing manpower to be used more effectively and efficiently for implementation of measures.

The following are sample retrofits performed on buildings during FY 1998:
- SWAP II, a pilot program designed to upgrade lighting and lighting controls was started. Potential savings from the implementation of SWAP II through operation and maintenance activities is more than $\$ 1$ million, with average payback of one year;

- Two chillers were replaced at the Chattanooga Office Complex (COC), with an estimated annual energy savings of more than $\$ 65,000$;

- Restroom lighting was retrofitted at the COC, saving an estimated $\$ 160$ per year;

- A motor was replaced on a COC air handler with an estimated annual savings of more than $\$ 295$;

- A variable frequency drive unit was installed, saving approximately $\$ 440$ annually;

- Phatocell lighting controls were installed on 400 watt high pressure sodium lights, saving more than $\$ 1200$ per year; and

- Energy management and control systems (EMCS) were installed at the Columbia Customer Service Center (CSC), Murfreesboro CSC, and Bowling Green CSC. Annual savings from these installations are expected to exceed $\$ 7,000$. TVA now has EMCS installed in 23 buildings.

During FY 1998, TVA also completed:

- Ninety-six fossil energy reduction projects at its Allen, Bull Run, Colbert, Cumberland, Gallatin, Johnsonville, John Sevier, Kingston, Paradise, Shawnee, and Widows Creek plants; and

- Nuclear energy reduction and environmental conservation projects at its Browns Ferry, Sequoyah, Watts Bar, and Bellefonte plants.

\section{Energy Showcases}

No new showcases were designated during FY 1998. The 738,500 gross square feet Knoxville Office Complex in Knoxville, Tennessee, is TVA's existing showcase. 


\section{Training}

TVA provides training for employees in order to accomplish objectives for the Internal Energy Management Program (IEMP). TVA provides updates on current Federal requirements and regulations for employees, managers, and TVA customers, when requested. Ongoing energy management training is provided to managers of facilities. Building energy monitors are appointed and trained for all primary corporate buildings. TVA also educates staff in both energy and environmental related topics through the TVA University.

\section{Funding}

TVA is establishing funding procedures for energy management projects under the IEMP and through the Agency Energy Management Committee. Buildings projects are primarily funded through renovation and modernization efforts. General operations projects are ranked for economic benefit compared to other TVA projects to determine funding availability and implementation status and are funded mainly through the capital budgeting process.

\section{Energy Savings Performance Contracts}

TVA considers the use of energy savings performance contracts when cost effective for TVA and its customers. During FY 1998, TVA did not enter into any energy savings performance contracts.

\section{Utility Partnerships}

TVA supports energy-saving demand-side activities when cost effective and in the best interest of its customers. TVA is currently investigating the potential for partnerships with its customers for development of demand-side programs and activities. Strategies recommended in TVA's Integrated Resource Plan (IRP) would increase TVA's activity in the implementation of demand-side management programs.

\section{Vehicles}

At the close of FY 1998, TVA was operating a sedan fleet consisting of 297 compact, 80 mid-size, and 75 full-size sedans.

In FY 1998, TVA did not purchase any alternative fueled vehicles (AFVs). TVA's AFV fleet currently consists of 15 electric vehicles (EVs), with plans to add 5 more during FY 1999.

\section{Environmental Activities}

TVA's affirmative procurement policy includes a statement that energy management and efficiency will be considered along with environmental impacts when new or replacement energy-consuming equipment is purchased.

In keeping with its goal of environmental responsibility, TVA became the first Federal agency to join the EPA/DOE Green Lights Program and is in the process of becoming a partner in the EPA/DOE ENERGY STARß Building program. TVA is also involved in solid waste minimization, sustainable architecture, byproducts with recycle content, reduction of green house gas programs, and other applications of environmental stewardship in conduct of its business.

In FY 1998, TVA became a partner in the Environmental Protection Agency's ENERGY STARß Building program. TVA also joined the Motor Master Program established by DOE.

TVA's Resource Group undertook many water and land management activities during FY 1998 to help reduce energy consumption and environmental impacts.

\section{Energy Management Contact}

Mr. Stephen L. Brothers, Jr.

Power Utilization Engineer.

Internal Energy Management Program

Technical Services Section

Tennessee Valley Authority

Facilities and Realty Management, EB 2E-C

1101 Market Street

Chattanooga, TN 37402-2801

Phone: 423-751-7369

Fax: 423-751-6309 


\section{UNITED STATES POSTAL SERVICE (USPS)}

Energy Efficiency Performance and

Implementation Strategies

In FY 1998, energy use in U.S. Postal Service facilities decreased by 18.1 percent in Btu per gross square foot compared to FY 1985.

\section{USPS Performance Toward Buildings Energy Reduction Goals}

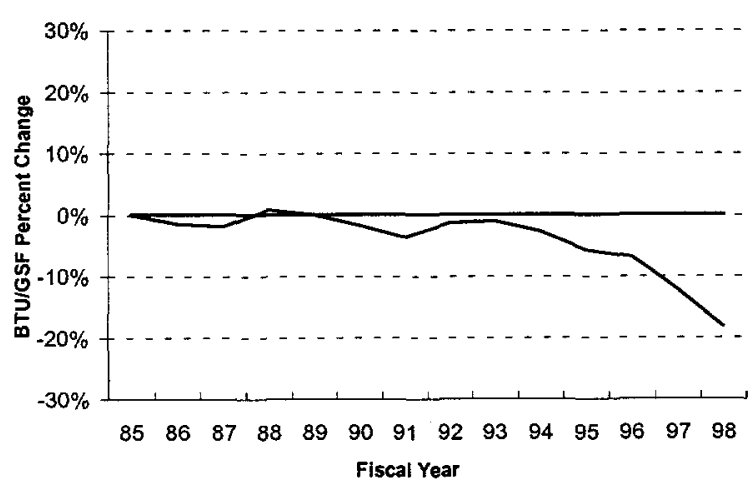

USPS Buildings Energy Use and Costs, FY98

$\begin{array}{lrr} & \text { BBtu } & \text { S (Thou.) } \\ \text { Electricity } & 13,903.9 & 300,734.5 \\ \text { Fuel Oil } & 646.8 & 4,158.4 \\ \text { Natural Gas } & 7,640.5 & 40,833.6 \\ \text { Other } & 492.7 & 4,855.3 \\ & & \\ \text { Total } & 22,683.9 & 350,581.8\end{array}$

The Postal Service's energy consumption index (ECI) decreased in FY 1998 from FY 1997. This decrease is due to three factors:

- Continuing replacement of old facilities with more energy-efficient facilities;

- The development of a comprehensive information system that can track energy costs more accurately; and

- A continuing effort to identify and update facility energy consumption data.

Because Postal Service facilities are energy-efficient because of past conservation efforts, continued efforts to further improve efficiency, at a time when energy prices at a historic all-time low, prove to be difficult. Moreover, the Postal Service has added more than
10,000 automated and mechanized equipment systems, significantly increasing Postal Service use of process energy.

The Postal Service's strategy to attain the energy consumption reduction goals are:

- Capital investment of energy conservation equipment;

- Affirmative purchasing of energy conservation products and services;

- Education and awareness of employees;

- Continued execution of energy savings performance contracts (ESPCs);

- Participation in demand-side management programs;

- Design and construction of energy-efficient buildings;

- Improved operation and maintenance procedures;

- Capital investments for energy retrofit projects;

- Procurement of energy-efficient equipment; and

- Installation of automatic controls.

The pace of completing additional comprehensive facilities audits will be determined on the basis of the Postal Service's capability to implement subsequent energy conservation projects. The Postal Service plans to focus its audit priorities on processing and distribution facilities and customer service facilities more than 10,000 square feet in size.

In FY 1998, more than 3,200 building surveys were conducted to establish priorities for energy conservation projects and additional comprehensive and detailed energy audits for identifying further energy savings opportunities.

In FY 1998, the Postal Service purchased and installed more than 30,000 light emitting diode (LED) exit signs. The total procurement cost is $\$ 750,000$, and the estimated savings are $\$ 2$ million over the total life cycle. 
The Postal Service is working with Granger, Inc., to develop a catalog of energy-efficient products and supplies for use by facility managers. Granger also agreed to perform motor surveys and provide replacement motor recommendations with a high energy efficiency rating.

During FY 1998, the Postal Service developed the USPS Green Building Design Guide, which provides design standards for energy-efficient systems. The guide also includes initiatives that incorporate environmental consideration in the design and construction of new facilities.

Application of renewable energy as an alternative fuel source is investigated as a part of energy surveys. In addition, the evaluation of renewable energy for securing dual-fuel capability is encouraged during the design process for new facilities. Several facilities have installed solar lighting in Hawaii and Southern California.

The USPS has entered a partnership with DOE in supporting further development and commercial application of solar and other renewable energy sources. The USPS will participate in DOE's effort by jointly developing projects and provide pilot cases where these projects and concepts could be tested.

\section{Energy Showcases}

The Postal Service has designated three buildings as "Showcase for Energy" facilities. These are located in Portland, Oregon; St. Paul, Minnesota; and Ft. Lauderdale, Florida. Energy audits have been completed at the three facilities, and various retrofit projects are scheduled for completion. These projects include:

- Installing T-8 lights with electronic ballasts;

- Upgrading central HVAC systems; and

- Installing better energy management controls.

The Postal Service is working with DOE, local utility companies, and other contractors to make these facilities examples of energy conservation and efficiency efforts.

\section{Training}

During FY 1998, the Postal Service developed a series of training seminars on Shared Energy Savings contracts, energy program management, and utilities procurement strategy. These training classes are attended by newly appointed energy managers and procurement officials responsible for buying utilities and awarding energy retrofit projects. The Postal Service will continue to provide additional training in energy as the need is identified.

Training materials have also been developed to emphasize the role and responsibility of contracting officers in complying with energy and environmental regulations.

\section{Funding}

Energy projects within the Postal Service are prioritized using criteria such as operational needs, safety and health issues, and environmental benefits, in addition to energy savings. Economic benefits are measured by net present value and return on investment to the Postal Service. Funds for implementation of energy retrofit projects may be provided by the local and area office budgets or by Headquarters.

In 1998 , the Postal Service centrally funded $\$ 16$ million for the purpose of improving the energy efficiency of its facilities. Headquarters and Area funds for energy retrofits are made available for projects that are prioritized based on return on investment. Projects are ranked primarily based on this and are funded until budgeted funds are depleted.

The Postal Service developed a 20-year program to replace CFC-based chillers. The Postal Service allocated $\$ 15$ million in FY 1998, and the funding priority is based on the energy efficiency gains, age of equipment, and scheduling of companion projects.

\section{Energy Savings Performance Contracts}

The Postal Service manages Shared Energy Savings (SES) contracts, equivalent to ESPCs. Since the first SES contract in 1987, the Postal Service has made significant progress in overcoming skepticism of the SES concept. Now, the Postal Service has 33 SESs in place for 1,157 facilities; the total estimated investment value is more than $\$ 79$ million; and the expected total energy savings are $\$ 7$ million per year.

In 1998, the Postal Service implemented eight additional SES projects, covering 455 facilities in:

- Louisville, Kentucky (5 facilities);

- Eastern Shore, Maryland (111); 
- Baltimore, Maryland (41);

- Dallas, Texas (8);

- Oklahoma City, Oklahoma (1);

- Tampa, Florida (260);

- Atlanta, Georgia (2); and

- Birmingham, Alabama (27).

Total investment was more than $\$ 43$ million, and the annual savings will amount to nearly $\$ 2$ million.

\section{Environmental Activities}

A quarterly newspaper for purchasing personnel covers specific energy and environmental issues. Development of energy-specific guidance for inclusion in the Postal Service Procurement Manual is ongoing.

Energy user awareness and recognition programs include several articles presented on energy efficiency initiatives on the USPS electronic postal link system. Facility and individual energy efficiency improvement awards were also presented to USPS employees.
The Postal Service participated in the "You Have the Power" campaign, distributing more than 10,000 posters throughout 36,000 postal facilities. Seven Postal Service energy champions are featured among these posters.

\section{Energy Management Contact}

Mr. Paul Fennewald

Environmental Programs Analyst

Environment Management Policy

United States Postal Service

Room 1 P830

475 L'Enfant Plaza, SW

Washington, DC 20260-2810

Phone: 202-268-6239

Fax: 202-268-6016 


\section{APPENDIX A \\ LIST OF AUTHORITIES}

ENERGY POLICY AND CONSERVATION ACT (Public Law 94-163), December 1975 SECTION 381 - FEDERAL ENERGY CONSERVATION PROGRAMS

DEPARTMENT OF ENERGY ORGANIZATION ACT (Public Law 95-91), August 1977 TITLE III - TRANSFERS OF FUNCTIONS

NATIONAL ENERGY CONSERVATION POLICY ACT (Public Law 95-619), November 1978

FEDERAL ENERGY MANAGEMENT IMPROVEMENT ACT OF 1988 (Public Law 100615), November 1988

ENERGY POLICY ACT (Public Law 102-486), October 1992

EXECUTIVE ORDER 12759, April 17, 1991

FEDERAL ENERGY MANAGEMENT

EXECUTIVE ORDER 12902, March 6, 1994

ENERGY EFFICIENCY AND WATER CONSERVATION AT FEDERAL FACILITIES

OFPP POLICY LETTER NO. 76-1, August 6, 1976

FEDERAL PROCUREMENT POLICY CONCERNING ENERGY POLIĆY AND CONSERVATION

SUPPLEMENT NO. 1 TO OFPP POLICY LETTER 76-1, July 2, 1980

\section{OTHER FEDERAL REGULATIONS}

FEDERAL ACQUISITION REGULATION

48 C.F.R. $\S \S 23.201-203$ (1995)

FEDERAL ENERGY MANAGEMENT AND PLANNING PROGRAMS 10 C.F.R., Part 436 (1996)

FEDERAL PROPERTY MANAGEMENT REGULATION

41 C.F.R., Part 101-25 (1996) 
This page intentionally left blank.

A-2 


\section{APPENDIX B \\ DATA COLLECTION}

Buildings and Facilities

Excluded Buildings/Process Operations

The Federal agencies that own or control buildings are required to report the energy consumption in these buildings to FEMP 45 days after the end of each fiscal year. The General Services Administration (GSA) reports the energy of buildings it owns and operates, including usage by other Federal agency occupants. For buildings which have been delegated by GSA to other agencies, the individual agencies are responsible for reporting the energy consumption and square footage figures.

The data shown in this report do not include leased space in buildings where the energy costs are a part of the rent and the Federal agency involved has no control over the building's energy management.

The Federal agencies submit their annual reports expressed in the following units: megawatt hours of electricity; thousands of gallons of fuel oil; thousands of cubic feet of natural gas; thousands of gallons of liquefied petroleum gas (LPG) and propane; short tons of coal; billions of Btu of purchased steam; and billions of Btu of "other." DOE reviews this data for accuracy and confers with the submitting agency to clarify any apparent anomalies. The data are then entered into a computer database management program.

The tables shown in this Annual Report are expressed in billions of Btu derived from the following conversion factors:

$\begin{array}{lll}\text { Electricity } & - & 3,412 \mathrm{Btu} / \text { kilowatt hour } \\ \text { Fuel Oil } & - & 138,700 \mathrm{Btu} / \text { gallon } \\ \text { Natural Gas } & - & 1,031 \mathrm{Btu} / \text { cubic foot } \\ \text { LPG/Propane } & - & 95,500 \mathrm{Btu} / \text { gallon } \\ \text { Coal } & - & 24,580,000 \mathrm{Btu} / \mathrm{short} \text { ton } \\ \text { Purchased Steam } & - & 1,000 \mathrm{Btu} / \text { pound }\end{array}$

In addition, the Federal agencies annually report to FEMP the gross square footage of their buildings and the cost of their buildings' energy.

This report excludes those agencies that have been unable to provide complete fiscal year consumption data prior to the publication date. All agency omissions, as well as any anomalies in the data, are indicated by footnotes on the tables or in the text of the report. 


\section{Vehicles and Equipment}

Federal agencies are required to report the energy consumption of their vehicles and equipment to FEMP within 45 days after the end of each fiscal year.

The fuels used in vehicles and equipment are automotive gasoline, diesel and petroleum distillate fuels, aviation gasoline, jet fuel, navy special, liquefied petroleum gas/propane, and "other." All the fuels in this category with the exception of "other" are reported in thousands of gallons.

"Other" is reported in billions of Btu.

The conversion factors for these fuels are:

$\begin{array}{lll}\text { Automotive Gasoline } & -125,000 \mathrm{Btu} / \text { gallon } \\ \text { Diesel-Distillate } & -138,700 \mathrm{Btu} / \text { gallon } \\ \text { Aviation Gasoline } & - & 125,000 \mathrm{Btu} / \text { gallon } \\ \text { Jet Fuel } & - & 130,000 \mathrm{Btu} / \text { gallon } \\ \text { Navy Special } & - & 138,700 \mathrm{Btu} / \text { gallon } \\ \text { LPG/Propane } & - & 95,500 \mathrm{Btu} / \text { gallon }\end{array}$

Missing data and anomalies are addressed in the same fashion as those described previously in this appendix. 


\section{Calculation of Estimated Carbon Emissions}

Carbon emissions were calculated by multiplying energy consumption for each fuel type by an associated carbon coefficient shown below. These coefficients are derived from DOE/EIA0573(98), Emissions of Greenhouse Gases in the United States, 1998, October 1999; Tables 11 and $\mathrm{B} 1$.

Carbon coefficients are calculated by dividing the carbon content of a particular fuel (for example, 0.85 metric tons of carbon per ton of fuel) by the energy content of that fuel (say, 43 million Btu per metric ton), producing an emissions coefficient (in this example, 19.8 million metric tons of carbon per quadrillion Btu (quad), which is the same as 19.8 metric tons per billion Btu). The different coefficients result from differences in the amount of carbon released when the various fossil fuels are burned. The amount of carbon released depends, in turn, on the density, carbon content, and gross heat combustion of the fuel in question.

The coefficients used in this report are as follows:

\section{Energy Type}

Electricity

Fuel Oil

Natural Gas

LPG/Propane

Coal

Purchased Steam

Auto Gas

Diesel

Aviation Gas

Jet Fuel

Navy Special

\section{Metric Tons/Billion Btu}

(Site-Delivered)

48.17

19.95

14.47

16.99

25.63

35.63

19.35

19.95

18.87

19.33

21.49

The electricity coefficient is based on 1995 carbon emissions from electric utilities per 1995 sitedelivered electricity consumption. (Table 11, DOE/EIA-0573(98) and Table 8.1, DOE/EIA0384(98), Annual Energy Review 1998.) This coefficient of 48.17 metric tons per billion Btu (or million metric tons per quad) is applied to site-delivered Btu consumption of electricity. It is equivalent to a coefficient of 14.12 metric tons per billion Btu used for primary Btu consumption of electricity and reflects a generation mix of electricity consumption of approximately 51 percent coal, 15 percent natural gas, 2 percent fuel oil, 20 percent nuclear, and 12 percent hydro/ renewables.

The purchased steam coefficient applies the coefficient for coal to the primary energy Btu (converted from site-delivered Btu by using a factor of 1.39). 
This page intentionally left blank.

B-4 


\section{APPENDIX C}

FEDERAL ENERGY EXPENDITURES,

FY 1985 THROUGH FY 1998 
TABLE C

FEDERAL ENERGY EXPENDITURES, FY 1985 THROUGH FY 1998 (CONSTANT 1998 DOLLARS)

Year

Buildings \& Facilities
1985
1986
1987
1988
1989
1990
1991
1992
1993
1994
1995
1996
1997
1998

\section{Vehicles \& Equipment}

1985

1986

1987

1988

1989

1990

1991

1992

1993

1994

1995

1996

1997

1998

\section{Energy Intensive Operations}

1985

1986

1987

1988

1989

1990

1991

1992

1993

1994

1995

1996

1997

1998

\author{
Annual \\ Energy Use \\ (BBTU)
}

$470,996.2$

$447,121.7$

$468,780.3$

$443,827.0$

$440,744.8$

$441,376.1$

$404,488.9$

$413,383.9$

$403,399.0$

$385,920.2$

$366,747.0$

$358,736.0$

$349,675.0$

$349,402.4$

\section{$934,333.0$ \\ $924,833.7$ \\ $958,904.3$ \\ $846,896.1$ \\ $959,994.5$ \\ $926,994.8$ \\ $970,454.3$ \\ $783,122.4$ \\ $772,633.7$ \\ $722,790.8$ \\ $687,143.4$ \\ $675,111.3$ \\ $665,385.6$ \\ $627,729.9$}

\section{Annual \\ Energy Cost \\ (\$ MILLION)}

$$
\begin{aligned}
& 5,732.004 \\
& 5,187.856 \\
& 5,188.398 \\
& 4,712.353 \\
& 4,305.996 \\
& 4,786.415 \\
& 4,350.590 \\
& 4,129.214 \\
& 4,304.976 \\
& 4,100.330 \\
& 3,816.736 \\
& 3,740.690 \\
& 3,592.137 \\
& 3,530.307
\end{aligned}
$$

$8,700.327$

$5,254.680$

$5,561.290$

$5,259.686$

$5,890.057$

$6,340.348$

$7,816.240$

$4,634.151$

$4,868.846$

$3,485.969$

$3,593.288$

$3,528.602$

4,073.332

$4,346.405$

\author{
Annual \\ Energy Cost \\ (\$MMBTU)
}

$$
\begin{array}{r}
12.169 \\
11.603 \\
11.068 \\
10.618 \\
9.770 \\
10.845 \\
10.756 \\
9.989 \\
10.671 \\
10.625 \\
10.407 \\
10.427 \\
10.273 \\
10.104
\end{array}
$$

\subsection{1 \\ 5.681 \\ 5.799 \\ 6.211 \\ 6.136 \\ 6.840 \\ 8.054 \\ 5.918 \\ 6.301 \\ 4.823 \\ 5.230 \\ 5.226 \\ 6.122 \\ 6.924}

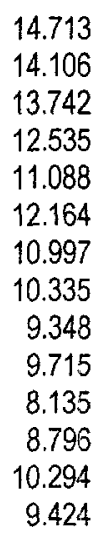

Change in Energy
Costs from 1985
(\$ MILLION)

$$
\begin{array}{r}
0.000 \\
-544.148 \\
-543.607 \\
-1,019.651 \\
-1,426.008 \\
-945.589 \\
-1,381.415 \\
-1,602.790 \\
-1,427.028 \\
-1,631.674 \\
-1,915.268 \\
-1,991.314 \\
-2,139.867 \\
-2,201.697
\end{array}
$$

$$
\begin{array}{r}
0.000 \\
-3,445.647 \\
-3,139.037 \\
-3,440.641 \\
-2,810.271 \\
-2,359.979 \\
-884.087 \\
-4,066.176 \\
-3,831.481 \\
-5,214.358 \\
-5,107.039 \\
-5,171.725 \\
-4,626.995 \\
-4,353.922
\end{array}
$$

$\begin{array}{rrr}582.260 & 14.713 & 0.000 \\ 538.387 & 14.106 & -43.872 \\ 529.509 & 13.742 & -52.751 \\ 871.060 & 12.535 & 288.801 \\ 706.719 & 11.088 & 124.459 \\ 790.869 & 12.164 & 208.609 \\ 917.224 & 10.997 & 334.964 \\ 1,010.311 & 10.335 & 428.051 \\ 659.400 & 9.348 & 77.140 \\ 684.471 & 9.715 & 102.211 \\ 614.855 & 8.135 & 32.596 \\ 649.676 & 8.796 & 67.416 \\ 674.260 & 10.294 & 92.000 \\ 621.337 & 9.424 & 39.077\end{array}$

${ }^{1}$ Changes in energy costs from 1985 should not be construed as savings resulting from Federal energy management activities. Many variables contribute to fluctuations in annual energy costs, including changes in square footage, building stock, weather, energy efficiency investments, service level, fuel mix, fuel prices, and vehicle, naval, and aircraft fleet composition. This table incorporates revisions to previously published energy consumption and cost data submitted to DOE by Federal agencies.

Source: Federal Agency Annual Energy Management Data Reports 


\section{APPENDIX D \\ BUILDINGS EXEMPTED FROM NECPA'S \\ PERFORMANCE GOAL IN FY 1998}

Section 543(a)(2) of NECPA states, "An agency may exclude from the requirements of paragraph (1) any building, and the associated energy consumption and gross square footage, in which energy intensive activities are carried out. Each agency shall identify and list in each report made under section 548(a) the buildings designated by it for such exclusion." These buildings are not included in the calculations for determining performance toward the buildings Btu/GSF reduction goals. Instead, they are included under the category of excluded buildings/process energy. The energy consumed in these buildings is included on tables and figures which show total consumption (buildings and facilities, vehicles and equipment, and excluded buildings/process).

\section{Department of Commerce}

National Institute of Standards and Technology

Gaithersburg. Maryland Sites

101 Administration

102 Gate House

202 Eng. Mech.

205 Fire Research

206 Concr. Mtrls.

220 Metrology

221 Physics Lab

222 Chemistry

223 Mtrls. Test.

224 Polymers

225 Technology

226 Building Research

230 Fluid Mech.

231 Industrial

233 Sound

235 Reactor CNRF

236 Hazards

237 Non-magnetic

238 Non-magnetic

245 Radiation

301 Supply and Pln.

302 SCWPG Cooling TWR

303 Service

304 Instr. Shops

305 Switchgear

306 Elec. Sub.

307 Chemical Waste

308 Bowman House

309 Grounds

310 Hazards Strg.

311 Grounds Strg.

411 TRF

412 Temp. Ofc
413 Temp. Ofc

415-418 Temp. Ofc

419 Temp. Childcare

Boulder. Colorado Sites

1 Radio

1A Radio Building

1B Radio Building

1C Radio Building

1D Radio Building

2 Cryogenics

2A Cryogenics - Annex A

3 Liquifier

3A Liquifier - Annex A

4 Camco

5 Camco Annex

8 Mesa Test Site

9 Gas Meter

11 Ionospheric Observatory

14 Field Strength

21 Maintenance Garage

22 Warehouse

24 Plasma Physics

24A Plasma Physics - Annex A

25 Maintenance Shops

26 Day Care Facility

27 High Frequency

National Oceanic and Atmospheric Administration

AKWO11 E.T. Shop

AKW129 Elec. Storg. Bldg. \& Fac.

AKW130 Marine Warehouse

ARM004 WFO

CAW072 SW Fisheries Cntr

CAW107 WSO 
CA4486 WSFO

COC004 WSFO

COM017 Optics Bldg \& Fac.

COM018 Lab. Bldg

COM019 Lab. Bldg

COM053 Lab. Bldg

CTE005 Chem. Storg. Bldg. \& Fac.

FLE078 Port of Miami

FLM024 WSO

HIW015 WSO

LAM048 Ofc. Bldg

MAE032 Morris Island Observ

MEE00S NWS Forecast Ofc

MOC036 WSFO

MOC037 NEXRAD Bldg

MSM011 WFO

MTW006 Radar Bldg

MTW0119 Balloon Infltn. Bldg

NCC001 Dive Locker \& Fac.
NEC008 Balloon Infltn. Bldg. \& Fac.

NMM021 WFO

NVW016 Balloon Infltn. Bldg

NY5451 30 Rockefeller Plaza

ORW012 Fire Station/WSO

ORW065 WSO

PAE013 Storage Bldg. \& Fac.

TNM006 WFO

TXM029 WSO

UTW004 Balloon Infltn. Bldg

VAE014 Antenna Deck \& Fac.

WAW052 Behavior Lab. \& Fac.

WVE002 NWS Bldg

Bureau of Census

Charlotte Computer Center

\section{Department of Defense}

Process energy use at Department of Defense (DOD) facilities, or "buildings" under the definition of PL 100-615, is separately identified from the building and facilities energy use reported under the goal of section 543. Some DOD facilities have both building and facility use, and process energy use. DOD actively manages process energy facilities in such a manner as to achieve a 10 percent energy efficiency improvement goal by FY 1995. The following lists those facilities which report process energy and are exempt from NECPA's performance goal.

$\underline{\text { Army }}$

Cold Region R\&E Lab, Hanover, NH

Stratford Engine Plant, CT

21st SUPCOM, Germany

Lima ARMODCTR, OH

Tobyhanna ARDEP, PA

Scranton AAP, PA

Radford AAP, VA

Redstone Arsenal, Huntsville, AL

V Corps, Frankfurt, Germany

Holston AAP, Kingsport, TN

Pine Bluff Arsenal, AR

Dist. Engr., New Orleans, LA

Louisiana AAP, Shreveport, LA

Sunflower AAP, Laurence, KS

Detroit Arsenal, Warren, MI

Lake City AAP, Independence, MO

Fort Leonard Wood, Waynesville, MO

Mississippi AAP, Picayune, MS

Navy

NSY, Portsmouth, NH

NSY, Philadelphia, PA

NAC, Indianapolis, $\mathbb{N}$
NSY, Portsmouth, VA

NSC, Norfolk, VA

NSY, Charleston, SC

NSY, Mare Island, CA

NSC, Oakland, CA

NSC, San Diego, CA

NSY, Puget Sound, WA

NSY, Pearl Harbor, Hawaii

NAVSUBASE, Pearl Harbor, Hawaii

NSC, Puget Sound, WA

NSC, Pearl Harbor, Hawaii

NSC, Charleston, SC

NSY, Long Beach, CA

NAPC, Trenton, NJ

NSRF Guam, Marianas Islands

NSSPO, Magna, UT

NARF, Alameda, CA

NARF, Jacksonville, FL

NARF, Norfolk, VA

NARF, San Diego, CA

NARF, Pensacola, FL

NARF, Cherry Point, NC

NSPASURSTA, Chula Vista, CA

NSPASURSTA, Maricopa, AZ

NSPASURSTA, Truth or Consequences, NM

NSPASURSTA, Archer City, TX 
NSPASURSTA, Lewisville, AR

NSPASURSTA, Hillandale, MS

NSPASURSTA, Wetumpka, AL

NSPASURSTA, Hawkinsville, GA

NSPASURSTA, Savannah, GA

NWIRP, Toledo, $\mathrm{OH}$

NIROP, Rochester, NY

Grumman Aerospace, Bethpage, NY

NIROP, Pittsfield, MA

NIROP, Minneapolis, MN
NIROP, Sunnyvale, CA

Allegany Ballistics Lab, Pinto, WV

NIRP, St. Paul, MN

NWIRP, Bloomfield, CT

NIROP, Pomona, CA

NWRIP, Bedford, MA

Grumman Aircraft Eng., Calverton, NY

DLA

DCSC, Columbus, $\mathrm{OH}$

\section{Department of Energy}

\section{Los Alamos National Laboratory}

Equipment Test Lab

Lab Meson Facility

Operations Bldg

Service Corridor

Accelerator Tec Bldg

LANSCE/WNR Bldg

Proton Storage Ring

High Res Beam Facility

General Purpose Lab

WNR Lab Support Facility

Warehouse

Proton Storage Staging Ring

FMIT Bldg

Accelerator Tec Bldg

Development \& Testing

Computer Maintenance

Data Analysis Center

Accelerator Maintenance Bldg

Sub-Stockroom/Wjse

JCl Craft Shop

Proton Storage Ring Eqp

Experimental Area

Neutron Scattering Exper

NPB Technical Support

Shop \& Storage BIdg

Office Bldg

Warehouse

Office Bldg

Med Resolution Spect

Neutron Exper Service

GTA Facility

ML Neutron Scattering

322 Trailers, Transportables \& Small Service Sheds

\section{Kansas City Plant}

Industrial Wastewater Pretreatment Facility

\section{Pantex Plant}

16-4/Paint and Sand Blast

16-10/Vehicle Wash

Security Lighting

Sandia National Laboratories, Albuquerque (Site No. 0112)

Building 880

Building 827

858/Microelectronics Development Lab

878/Process Development Lab

Naval Petroleum and Oil Shale Reserves in Colorado, Utah, and Wyoming

Maintenance Shop

LTS Gas Plant Main Compressor Building Steam Generator \#1 Facility

Warehouse Quonset

Water Treatment Facility

Field Core Facility

Steam Generator \#2 Facility

Steam Generator \#3 Facility

Steam Generator \#4 Facility

Steam Generator \#5 Facility

Field Operations Office

Environmental, Safety, and Health Office

Water Treatment Facility Expansion

UPS Building

LTS Gas Plant Office

Water Disposal Facility

LTS Gas Plant Shop

Polymer Plant

LTS Gas Plant PAMCO Building

LTS Gas Plant Lab

LTS Gas Plant Pump House

Fireflood Pump Building

South Terminal Main Building

South Gate Guard Shack 


\section{Idaho Operations}

Utility Building

Laboratory

Transportation Complex

Service Building Powerhouse

New Waste Calcining Facility

Coal-Fired Boiler House

Coal Plant Unloading Building

Liquid Effluent Treatment and Disposal Facility

Hot Shop/Manufacturing and Assembly

SMC Manufacturing and Assembly

ATR Building

ATR Cooling Tower Pumphouse

Deep Well Pump-House \#4

Diesel Generator Building

Waste Heat Recovery Building

\section{ICF Kaiser, Hanford Site}

Riggers Loft

Tritium Vault

Tritium Laboratory

6 Reactor Facilities

Decon Station Foundation

4 Effluent Water Outfall Structures

3 Retention Basins

Filter Plant Power Operation Facility

Mechanical Development Lab (D\&D in prog-'94)

Main Pump House

Fresh Metal Storage

Development Laboratory (D \& D in Prog-'94)

Main Pump HSE-Includes North and South Annex

Biology Laboratory

ERDS Towers On Hanford Site

Warehouse

Mobile Office@105H

Change Room Trailer@105H

Mobile Office (FKA:1131N)

Mobile Office@105H

Gas Recirculation Building

2 Exhaust Air Sample Building

Power Control Building Columbia River Monitorin

Effluent Water Treatment Pilot Plant

Water Studies Semiworks Facility

Offices and Telephone Exchange

Filter Plant Head House, Chlorine

11 Office Buildings

Badge House Temporary

3 Carpenter Shops

Change Room Building

Crib Effluent Iodine Monitoring Facility

9 Storage Buildings

Demineralization Plant Building

Fuel Oil Storage Tank and Unloading Platform

Vehicle Gate Inspection Bldg
Patrol Boat House

Rivr Guard Tower

Mobile Office W. of 1167A

Process Facility

Tank Farm Waste Support Facility

Gas Preparation Building

Underground Waste Storage Tank Farm

Waste Disposal Tank Farms (4)

Tank

Tank and Vault

Radioactive Particle Research Laboratory

Cask Loading Building

Guard Station for 209E

Office Administration and Gate House

Office Administration Building

Paint Storage Building

Critical Mass Storage

Office Machine Storage

Field Mobile@ Slab Yard

Canine Facility

Fabrication, Mockup Shop Building

Warehouse Essential Materials, NO. Of Purex

Solvent Handling Building

Filter Building

Fanhouse

Mobile Office @ 4th \& Baltimore (57B)

Graphics Facility@284E (ATT TO MO931)

Survey Mobile Office @ 4th \& Baltimore (2910E)

Change Room Trailer@284E

Mobile Office@202A (ATT'D TO MO948)

Mobile Office @202A (ATT'D TO MO542)

Mobile Office@202A (ATT'D/ID'D MO355)

Mobile Ofc@ Baltimore N/O 4th

2 Mobile OFC@Baltimore N/O 4th

1 Janitorial Storage @284E

2 Mobile Office@200 Area ETF

Mobile Office@ Baltimore N/O 4th

Mobile Office @ 4th \& Baltimore

Lunchroom Trailer @ Slab Yard

Mobile Office@4th \&Baltimore (AKA: 2910E)

Graphics Trlr@284E (ATT MO203)

4 Mobile Office @ 4th and Baltimore (AKA:2911E)

Mobile Office@ Purex

Mobile Office@202A (ATT'D/D'D AS MO347)

Mobile Office@ 224B

Office Administration Building

Office and Laboratory Building

Concentration Facility, U03 Plant

Calcination Facility

Electrican Shop

Pipefitter Storage

Pipefitter Small Shop

Gas Bottle Dock

Pipefitter Small Shop

Sheetmetal Shop

Material Storage 
Insulator Shop

Paint Storage(W-25)

Laborer Storage

Non-Tracable Bench Stock Storage

Ice House

Heavy Equipment Operator Shack

Paint Mixing Shop

Paint Shop

2 Paint Storage

Mask Laundry and Office Building

Materials Engineering Laboratory

Waste Incinerator Facility

Plutonium Concentration Facility

Exhaust Filter Building

Change House

Coal Handlers Shelter

First Aid Station and Offices

Office and Service Building

PU Storage

Welding Laboratory Building

D\&D Female Change Trailor @ 271T

Chemical Storage Warehouse

Power House Stream Plant

Packaged Boiler

Water Tower

Exhaust Fan Control House and Stack

Jet Pit House

Acid Recovery and Gas Treatment Building

2 Mobile Office @2704w

Mobile Office@222T

SWP Changeroom Trailer@211U

Decon Trailer@242S

Material Evaluation Laboratory

Material Storage Building

Waste \& Material Storage

Uranium Oxide Facility

Uranium Concretion Facility

Uranium Concretion Change Room

Electrician and Pipefitter Shop

Storage

Materials Development Laboratory

2 Fuel Development Laboaratory

SP-100 Ges Tesr Facility

Emergency Storage, Part if 309 Building

N Fuel Manufacturing Support FAX.

Engineering Development Laboratory

Stress Rupture Test Facility

Hydromechanical/Seismic Facility

Model Heat Loop, Part of 321 Building

Mechanical Properties Laboratory

Chemical Engineering Building

Stack Sampling Facility

Post Irradiation Test Laboratory

Virology Laboratory

Dog Kennel

Animal Resources Storage Building
Packaging Test Facility

N Fuel Building

Waste Acid Storage Building

Waste Neutralization Facility

Waste Retention Building

Maintenance Shop

Communication and Documentation Services

Change House

Radioanalytical Laboratory

Organic Chemistry Laboratory

Spare Parts Warehouse

Materials Archive Building

Laboratory Equipment Central Pool Building

Sodium Storage Facility

Chemistry and Metal Sciences Laboratory

Classified Incinerator Facility

Fabrication Shop

Solvent and Acid Storage Building

Emergency Air Bottle Bldg(ATT to 3701d)

Classified Vault

Geotechnicl High-Bay

Gamma Irrdiation Facility Laboratory Equipment

Central Pool

Graphite Machine Shop

Paint Storage Building

Radiological Calibrations and Standards

Electron Acclerator Facility

Irradiation Physics Building

Conference Training Building

Technical Security

Offices

Laboratory

Mobile Office 329 T.2

Mobile Office 329 T.1

Mobile Office (377 Trl 1)

Mobile Office 3760 T.1

Mobile Office ( $3745 \operatorname{Trl} 1)$

Mobile Office 326 T.2

Mobile Office 306W T.2

Mobile Office 328 T.5

Mobile Office (3705 Trl 1)

Mobile Office (318 Trl 3)

Mobile Office 331 T.5

Mobile Office (323 Trl 2)

Mobile Office (333 Trl 1)

Mobile Office 306 W T.6

Mobile Office (366 Trl 4)

Mobile Office (3770 $\operatorname{Trl} 2)$

Mobile Office (3770 Trl 1)

4 Mobile Office

Mobile Office 318 T.2

Mobile Office @ FMIT

Mobile Office 325 T.1

Mobile Office 320 T.2

Mobile Office (FMIT TRL 3)

Mobile Office (FMIT TRL 5) 
Escort Trailor

Mobile Office to be Excessed 7/94

Mobile Office Also Known As 377 Trl 2

HPT Office@340

Mobile Office 306W T.5

Mobile Office Shop (306 Trl 7)

Mobile Office (FMIT Trl 9)

Mobile Office N/O 4 th \& Buffalo (A Farm)

Mobile Office (FMIT Trl 4)

Mobile Office 3760 T.3

Mobile Office (FMIT Trl 10)

Mobile Office (3763 Trl 1)

Mobile Office to be Excessed 10/94

Mobile Office@ ESML Constr. Site

Radio Maintenance Shop(655W-AVE)

$X$ Ray Facility

Sand Blast Facility

Telephone Exchange (959FIRSTST)

Hevy Equipment Repair Shop and Office

Oil Storage

Bottled Gas Storage

Fabrication Shop

Compressor Shop

Warehouse and Safety Hall

Combustible Material Storage

Administration Building

Administration and Engineering Office Bldg

Office Building (2770U-Ave)

Consolidated Personnel Building

Telecommunication Shop @1154(2671W-Ave)

Telecommunications Office @ 1154 (2675W-Ave)

Mobile Office Near 1262 Building (2730U-Ave)

RestroomTrlr@1209 Bldg Gate

Telecommunications Office@ 1154 (2665W-Ave)

Men's Restroom Trailers S. Of 1226

Previously Called Trl. 4 Near 1301

Mobile Office Att to 1154-Formerly TrlF 7

Mobile Office Near MO-850(2726U-AVE)

Field Changeroom Trailer S of 1226

2 Telecommunications Parts Storage @1154

Mobile Office@1154 (2667W-AVE)

Mobile Office (2735U-AVE)

Mobile Office Near 1226(2648W-AVE)

Mobile Office @ EMSL Site EMSL Tr.1

Visitor's Center

Training Facility

Maintenance and Storage Facility (MASF)

Former Guard Station, Kentucky Blvd

Guard Station, Grant Ave.

Guard Station, Hayes St.

Security Maintenance Shop

400 Area Fire Station

400 Area Site Support Office

Medical Aid Station

Site Service Maintenance Shop

Warehouse (Special Tools)
Warehouse

Mobile Office Of W. Of 4706

Mobile Office (Trl 100) W. Of 4706

Mobile Office (Trl 102) W Of 4706

Field Trailer W. Of 4706

Mobile Office W. Of 4706

Patrol Utiltity Building

Radioecology Field Laboratory, Rattlesnake SPRI

Space Science Laboratory

Pump House

Lysimeter Preparation Building

Ale Field Storage Building

ALE Laboratory 11

Pump House

Fallout Laboratory

Fire Protection Pump House

Mobile Office@ Grout

Escort Trailor@, Gate 814

Mobile Office s/o 622G

Portable GEN/Water Tank @ CTRL Landfill

Mobile Office@243G

Boar House/Storage Building

Sovannah River Operations Office

3 Pumphouses

4 Reactor Buildings

4 Area Cooling Water Pumphouses

4 Area Fuel Unloading Facilities

4 Emergency Diesel Generator/Fuel Oil Storage

Facilities

Brookhaven National Lab

Accelerator Storage

Medical Research Reactor

AGS Switchhouse

Pumphouse, Cooling Tower

Valvehouse

Equipment House

NAT Synchrotron Light Source

Gamma-Ray Beam Reactor

High Flux Beam Reactor

Cold Neutron Facility

Fanhouse

Dynam Van De Graaff

Cyclotron

Machine Shop

Tandem Van De Graaff

Magnet Development

Magnet Assembly

Electricians Work Area

Cryogenic Test Facility

Pett VI

Heavy Ion Power Supply A 
Heavy Ion Power Supply B

Heavy Ion Beam Tunnel

AGSExperimental Halls

Mechanical Equipment

AGS Tunnel

Fan House A

Fan House $B$

Fan House C/A-10 House

Fan House D

Fan House E

Proton House D18

Proton House E18

Proton House F18

Proton House G18

Proton House H18

Proton House I18

Proton House J18

Proton House K1 8

Proton House L18

Booster Equipment House L18A

Proton House A18

Proton House B18

Proton House C18

H-10 Equipment House

Booster

Warehouse

7 Works Building

E-10 Power Supply

Exp. Power Supply Building G-2

Scientific Assembly

Works Building

N. Experimental Tunnel

MG Power Supply

RF Power Supply

200 MEV Linac

Irradiation Facility (Cliffo

Isotope Producer (BLIP)

F-10 House Equipment

Radiation Effects Tunnel

On-Line Data Facility

Booster Tunnel

Blip Pump House

4 Storages

Dead Storage

Experimental Computer/Electrical Building

Compressor Building

Electronic Equipment Repair

Strategic Petroleum Reserve

41 Field Instruments Buildings

5 Foam Storage Buildings

6 Control Center Buildings

Maintenance Building

Foam Storage A Building
Potable Water Building

5 Sky Switchgear Building

Maintenance Strg equipment Building

3 Soc Building

Main Guard House Building

3 Property Warehouse Buildings

4 Flammable Storage Buildings

3 Foam Deludge Building

Rwis Pump Hpuse Building

2 Gun Cleaning Building

Weld Shop Building

Grass Maintenance Equipment Building

2 Foam Generator Buildings

Maintenance Facility Building

Radio Repairer Building

Skva Supr Bloc F \& G

1 Firewater Pumps

6 Administration Buildings

Fire Pumps on Trucks Building

Paper Recycling Building

Guard House Building

Electrical Moa Building

Substation Electrical Building

Deludge Valve Building

Moc Be-2 Building

Guard House Corner Building

3 Gun Cleaning Building

Water Storage Building

2 Motor Control Center Building

Maintenance \& Warehouse Building

Erner Properness Building

Rwis Ups Building

2 Communications Buildings

Warehouse E Building

Main Fire Water Building

Fire At Black Lake Building

ACUS Small Shed

Control Room Taxoma Building

Sky Foam Deluge Building

Fab Shed Building

Deluge Valve

Flammable Storage Shed

Guard Conet Gate Building

Ravis Microwave Building

Ravis Computer Conrno Building

Sky West Building

Sky East Building

Switchgear Building

Contruction and Maintenance Building

Sample Lab Building

Pump House Foam Building

Inert gas Gen Building

P/S Head Frame

MOCS s/s Area Building

Equipment Storage Building 
Fire Truck Building

Well Water Pump Hou Building

Fire Transformer Dei Building

Fill Site Storage Building

Maintanance Receiving Building

Lab Building

Radio Tower Building

Guard House On Site

Foam Prop. \#3 Building

Foam Prop.\#2 Building

Foam Prop. \#1 Building

Foam Prop. \#4 Building

Operator Control Dk1 Building

Operator Control Dk2 Building

Foam Prop Dock 1 Building

Firewater Pump Dk 1 Building

Foam Prop. Dock 2 Building

Property Whse/Maint Building

Vehicle Maintenance Building

Wash Rack Building

Wheeled Equip Building

Sample Storage Building

Gatehouse Front Hard Building

Gatehouse \#3 Building

Firewater Pump Building

Foam Proportioning Building

Covered Laydown Building

Rwis Guardhouse Har Building

Substation Building

Rwis Control Building

Prefab. Paint Storage Building

Rwis Comm Building

Microwave Building

HPP/Permit/Fire Pump

S/S Hoist

S/S Head Frame

2 Property Warehouse

Warehouse D

Rwis

Warehouse Guard House

Stanford Linear Accelerator Center

Accelerator Tunnel

Klystron Gallery

Beam Switch Yard (BSY)

Damping Ring Vault, South

Damping Ring Vault, North

Damping Ring RF - South

Damping Ring RF - North

Collider Housing North Arc

Collider Housing South Arc

Power Conversion

Casting Pad Shelter

Test Laboratory
Hydrogen Furnace Housing

Deionization Plant

Main Control Center (MCC)

Cryogenics Building

Test Cell Facility

Electronics Building Annex

End Station A

Final Focus Test Beam Bldg

Final Focus Test Beam Bldg

Bubble Chamber 140 "

Bubble Chamber Bldg / 82"

Spear Interaction Area/East

Spear Control Building

Spear Interaction Area/West

SSRL, North Annex

Test Beam Facility (TBF)

SSRL South Arc Building

SSRL Lab/Office/Shop Bldg

SSRL Spear Injector (in Const.)

Van Group D

Experimental Control C-Beam

East Pit Control Room

82" BC Support

82" BC Support

Control Room B/L 19

Cryo Eng. \& Operations

West Pit Detector Support Bldg

Beamline 6 Test Building

Final Focus Test Beam

Laser Storage Building

E 137 Experimental Building

IR 2 Hall

IR 2 Hall Annex

IR 2 Counting House

IR 2 Support Building

IR 4 Hall

IR 4 Counting House

IR 4 Support Building

IR 6 Hall

IR 6 Counting House

IR 6 Support Building

IR 8 Hall

IR 8 Support Building

IR 10 Support Building

IR 12 Hall

IR 12 Counting House

IR 12 Support Building

SSRL PBF 18

CEH SLC Experimental Hall

MkII Leach

MCC Portable Building

Light Fabrication Building

Heavy Fabrication Building

Plating Shop Annex

Vacuum Assembly Building 
Light Assembly Building

EFD Shops and Storage

EFD Shop Building

Rigging Loft
PMU Shops Building

Transport Tire Shop

Electronics Shop Trailer

Research Yard Machine Shop

\section{Department of Transportation--Federal Aviation Administration}

62 Automated Flight Service Stations

Airport Information Desk

Automated International Flight Service Station

119 Approach Light Systems

Airway Beacon

127 Air Route Surveillance Radar -

FAA and Military

Air Route Traffic Control Center

189 Automated Radar Terminal Systems

23 Airport Surface Detection Equipment

647 Altimeter Setting Indicators

263 Airport Surveillance Radar -

FAA and Military

568 Airway/Terminal Building Maintenance

23 Air Traffic Control Beacon Interrogator

331 Air Traffic Control Radar Beacons

464 Airport Traffic Control Towers

398 Automatic Terminal Information Systems

356 Automated Weather Observing Systems

Aerial Tramway

597 BRITE Radar Indicator Terminal Equipment

294 Backup Emergency Communications

116 Computer Based Instruction

2 Central Computer Complexes

120 Closed Circuit TVs

229 Common Digitizers

10 Cloud Height Indicators

Computer Display Channel

Combined Center/RAPCO

11 Control Circuit Equipment

407 Control Line Maintenance

17 Communications Microwave Link Terminals

23 Command Communications Outlets

Center Building Maintenance

23 Direct Access Radar Channels

Display Channel Complex

337 Direction Finders - VHF

226 Direction Finder Indicators

584 Distance Measuring Equipment

51 Distance Measuring Equipment Remaining

558 Data Multiplexors

811 Data Terminal Equipment

En Route Automated Radar

Tracking System

5 Electronic Data Processing Systems

468 Electrical Distribution Systems

12 Emergency Operating Facilities

50 Flight Data Entry and Printout
23 Flight Data Input/Output Centers

391 Flight Data Input/Output Remotes

Flight Data Remoting System Intermediate

Fields and Landing Areas

39 Fan Markers

20 Flight Service Data Processing Systems

189 Flight Service Stations

46 Ground/Air Transmitter Receivers

Guidance Light Facility

Gap Filler Radar

85 Geostationary Operational

Environmental Satellite Systems

864 Glide Slopes

1143 Homing Radio Beacons

5 Central Heating Facilities - Per Unit

22 Heliports

Homing Radio Beacon - High Power

1 International Aeronautical

Telecommunications Switching Center

260 Integrated Communications

Switching Systems

26 Identification, Friend or Foe

International Flight Service Station

International Flight Service

Transmitter Station

81 Inner Markers

136 VHF/UHF Link Terminals

23 Localizer Type Directional Aids

20 Lead-in Light Facilities

37 Living Quarters

114 Low Level Wind Shear Alert Systems

Compass Locator at the ILS

Middle Marker

4 Link Repeaters

1053 ILS Localizers

473 Compass Locators at the ILS

Outer Marker

94 Medium-Intensity Approach

Lighting Systems

633 Medium-Intensity ALS (MALS)

with Runway Alignment

Indicator Lights (RAIL)

4 Meteorological and Aeronautical

Presentation Systems

9 Marine Equipment Boats and Docks

625 Multichannel Recorders

17 Military Height Finder Radar 
33 Military Interface Groups

Military Interface Modification

272 Microwave Landing Systems

Azimuth

160 Microwave Landing Systems

Back Azimuth

271 Microwave Landing System Distance

Measuring Equipment Precision

276 Microwave Landing System Elevation

1 Microwave Landing System Flare

828 Middle Markers

14 Mobile Laboratories

105 Mode S/Data Links

46 Maintenance Processing Systems

400 Mobile Engines or Generator Plants

28 National Data Interchange Networks

1282 National Radio Communications Systems

39 Next Generation Weather Radar

65 Off Airways Weather Stations

50 Omnidirectional Airport Lighting Systems

Oceanic Display and Planning System

325 Heavy Equipment and Off-Road Vehicles

831 Outer Markers

General Oil Distribution System

180 Precision Approach Path Indicators

2 Precision Approach Radar

707 Power Conditioning Systems

19 Primary Power Engines or Generator Plants

68 Quarters Building - Other than

Living Quarters

8 Radar Approach Control - Air Force

111 Rotating Beam Ceilometers

11 Radar Bright Display Equipment

22 Radar Beacon Data Processor Equipment

277 Remote Beacon Performance Monitor

685 Remote Center Air/Ground

Communications Facilities

99 Remote Control Interface Units

752 Radio Communications Link Repeat

233 Radio Communications Link Terminals

1837 Remote Communications Outlets

692 Runway End Identification Lights
215 Remote Monitor Control Facilities

214 Radar Microwave Link Repeaters

138 Radar Microwave Link Terminals

189 Remote Readout Hygrothermometers

95 Radar Remote Weather Display Indicators

135 Radar Remote Weather Display Systems

12 Remote Tower Communications

Control Systems

1222 Remote Transmitter Receivers

537 Runway Visual Range

Shortened Approach Light System

Sanitation System

661 Storage Buildings

Systems Command Center

Sensor, Receiver, and Processor

72 Simplified Short Approach Lighting

Systems with Runaway Alignment

Indicator Lights (RAIL)

Simplified Short Approach Lighting System

Self Sustained Outlet

49 Sewerage Systems

666 Tactical Air Navigation

8 Tower Cab Digital Displays

144 Terminal Data Display Systems

496 Telephone Exchanges

589 TELC Interface Maintenance

19 Terminal Information Processing Systems

125 Television Microwave Link Indicators

110 Television Microwave Link Repeaters

138 Television Microwave Link Transmitters

414 Tower Buildings

529 Trails and Roads

25 Terminal Radar Approach Controls

17 Teletypewriter Facilities

137 Transcribed Weather Broadcast

743 Utility Buildings

1387 Visual Approach Slope Indicators

769 Vehicle Maintenance

1025 VHF Omnidirectional Range

95 VHF Omnidirectional Range Test

Weather Message Switching Center

Water System Maintenance 


\section{General Services Administration}

Region 1

GSA Cd Depot 234, Watertown, MA

Federal Building, Lowell,MA

EPA Laboratory, Lexington, MA

US Border Station, Calais, ME

US Border Station, Coburn Gore, ME

US Border Station, Fort Fairfield, ME

28 Lord Road, Marlborough, MA

US Border Station, Houlton, ME

US Border Station, Jackman, ME

US Border Station, Limestone, ME

US Border Station, Orient, ME

US Border Station, Vanceboro, ME

US Border Station, Van Buren, ME

US Border Station, Calais, ME

USBS,St.Pamhille, Saint Francis, ME

US Border Station, Madawaska, ME

USBP Sec Hd Houlton, Hodgdon, ME

Parking Facility, Portland, ME

US Border Station, Fort Kent, ME

Warren B. Rudman, Concord, NH

USBS Highgate Springs, VT

US Border Station, Derby Line, VT

US Border Station, Highgate Springs, VT

US Border Station, Norton, VT

US Border Station, Beebe Plain, VT

US Border Station, Alburg Springs, VT

US Border Station, North Troy, VT

US Border Station, West Berkshire, VT

US Border Station/USPO, Derby Line, VT

US Border Station, Beecher Falls, VT

US Border Station, Canaan, VT

US Border Station, East Richford, Richford, VT

US Border Station, Richford, VT

Border Station, Sector Hdqtrs, Swanton, VT

US Border Station, Twp20, Saint Francis, ME

US Border Station, Township 11, Saint Francis, ME

Swanton Bdr Ptl Building, Highgate Springs, VT

\section{Region 2}

3000 JFK Blvd., Jersey City, NJ

FB, New York-Kings, NY

Border Station, Rouses Point, NY

Mech Equip Garage, Champlain, NY

Corporate Place, Rochester, NY

17 Cronin Road,Glens Falls, NY

10 Bouck Ct, New York-Kings, NY

25-27 East Park Ave., Long Beach, NY

80-02 Q Gardens, New York-Queens, NY

Century Mall, Amherst, NY

16 Court St. Bklyn, New York-Kings, NY

B\&B Bldg, San Sebastian, PR

Nazario Building, San German, PR
AL Cohen Plaza, Charlotte Amalie, VI

US Border Station, Champlain, NY

Inspection Bld Borde, Chateaugay, NY

Main Inspector Station, Massena, NY

Inspection Building, Mooers, NY

US Border Station, Fort Covington, NY

US Border Station, Rouses Point, NY

US Border Station, Trout River, NY

Administration Building, Alexandria Bay, NY

Gateway I, Newark, NJ

W/S Jamiesons Line, Burke, NY

Quaker Village, Glenn Falls, NY

NY5 Washington Sq Alba, Albany, NY

Greenway Plaza, Melville, NY

76 Eleventh Avenue, New York, NY

Mayaguez Mall, Mayaguez, PR

Region 3

Annapolis Comm. P.K.E, Annapolis, MD

Gwynn Oak Building, Woodlawn, MD

Federal Building 01, Philadelphia, PA

The Metro Center, Philadelphia, PA

5000 Wissahickon Ave., Philadelphia, PA

Erie Library, Erie, PA

Custom House, Norfolk, VA

Berris Plaza, Philadelphia, PA

Gateway, Philadelphia, PA

Wise County Plaza, Wise, PA

FairGrounds Dist Ctr, Richmond, VA

Region 4

FB PO, Port Gibson, MS

Battlefield Mall, Vicksburg, MS

Judicial Building, Biloxi, MS

MICC-DEA Warehouse, Miami, FL

E Pointe Bus Ctr, Jacksonville, FL

Cobb Corporate Ctr, Marietta, GA

BP Building, Macon, GA

Courthouse Annex, Columbia, SC

Region 5

Illini Fin Center, Springfield, IL

GSA Interag Mtr Pool, Chicago, IL

US Border Station, Sault Ste Marie, MI

Fed Parking Facility, Detroit, MI

Cust Cargo Insp Fac, Detroit, MI

US Border Station, Grand Portage, MN

Custom \& Immig Stat, Noyes, MN

US Border Station, International Falls, MN

Federal Building, Medina, $\mathrm{OH}$

Federal Building, Zanesville, $\mathrm{OH}$

Fed Parking Facility, Dayton, $\mathrm{OH}$

Bankers Building, Chicago, IL 
Social Security Building, Danville, IL Park Ridge Ofc Ctr, Park Ridge, IL O'Hare Lake Ofc Plz, Des Plaines, IL Insurance Exchange B, Chicago, IL Plaza Tower Office, Evergreen Park, IL Clyde Savings Building, North Riverside, IL 2100 N California, Chicago, IL

Wash Bicentennial Bg, Springfield, IL Smoke Tree Bus Park, North Aurora, IL Glen Hill North Bg A, Glen Ellyn, IL 10 West Jackson Blvd, Chicago, IL O'Hare Lake Off. Pla, Des Plaines, IL One Congress Center, Chicago, IL E Empire \& Eastport, Bloomington, IL Burrell Building, Chicago, IL Oakmont Corporation, Westmont, IL 1455 Golf Mill Road, Des Plaines, IL 1279 North Milwaukee, Chicago, IL Bank Of America, Chicago, IL 901 Warrenville Road, Lisle, IL 1700 South Wolf Road, Des Plaines, IL Elm Plaza So. Tower, Hinsdale, IL Soc. Sec. Office, Chicago, IL 125 Fairfield Way, Bloomingdale, IL IL Business Center, Springfield, IL 2360 E. Devon Ave., Des Plaines, IL 923-25 Dillon, Wood Dale, IL River Center, Chicago, IL Schaumburg Atrium, Schaumburg, IL 600 Joliet Rd, Willowbrook, IL 2350 E. Devon, Des Plaines, IL Gateway IV, Chicago, IL Citicorp Center, Chicago, IL Liberty Business Park, Elk Grove Village, IL 29 North Wacker Drive, Chicago, IL Governors' Off. Park, Olympia Fields, IL One Oakbrook Terrace, Oakbrook Terrace, IL Xerox Centre, Chicago, IL Stewart Square, Rockford, IL 635 Butterfield Rd, Oakbrook Terrace, IL Governors Off Pk IV, Olympia Fields, IL Glenwood Plaza, Glenwood, IL. Northwestern Building, Evanston, IL The Rookery, Chicago, IL 1600 Corporate Cntr, Rolling Meadows, IL 4849 N. Milwaukee Av, Chicago, IL AT\&T Corporate Cntr, Chicago, IL 801 Warrenville Road, Lisle, IL 1000 Tower Lane Building, Bensenville, IL Olympian Office Cntr, Lisle, IL The Park at NW Point, Elk Grove Village, IL 945 Lakeview Parkway, Vernon Hills, IL 2860 River Road, Des Plaines, IL One S. Wacker Building, Chicago, IL Governors Office Pk, Olympia Fields, IL
Fox River Center, Ottawa, IL 1600 Lebanon Avenue, Belleville, IL Lakeside Ofc Building, Indianapolis, IN 429 Penn Center, Indianapolis, IN The Furniture Co., Grand Rapids, MI Ambassador Bridge, Detroit, MI Arlington Plaza, Sault Ste Marie, MII 5015 South Cedar Str, Lansing, MI Domino's Farm House, Ann Arbor, MI Brewery Park Phase I, Detroit, MI Plaza Nine Building, Cleveland, $\mathrm{OH}$ Commerce Place, Middleburg Heights, $\mathrm{OH}$ Plaza South I, Middleburg Heights, $\mathrm{OH}$ Sanning Apartments, Cincinnati, $\mathrm{OH}$ One Cleveland $\mathrm{Ctr}$, Cleveland, $\mathrm{OH}$ Lakewood Center West, Lakewood, $\mathrm{OH}$ Plaza South I, Middleburg Heights, $\mathrm{OH}$ 2026 West Main Stree, Springfield, OH Corporate Center, Middleburg Heights, $\mathrm{OH}$ 4411 Montgomery Road, Norwood, OH CBLD Building, Cincinnati, $\mathrm{OH}$ Bank One Center, Cleveland, $\mathrm{OH}$ Eaton Center, Cleveland, $\mathrm{OH}$ Wright Executive Ctr, Fairborn, $\mathrm{OH}$ Renaissance, Cleveland, $\mathrm{OH}$ 228th \& Lake Shore B, Euclid, OH Society Tower, Cleveland, $\mathrm{OH}$ 6161 Oaktree, Independence, $\mathrm{OH}$ Rockside Center III, Independence, $\mathrm{OH}$ Old Bayfield Cthse, Bayfield, WI Social Security Off, Wisconsin Rapids, WI Vander Heyden II, West Bend, WI 575 Lester Street, Onalaska, WI 1830 2nd Ave. Rock Island, IL Midway Business Ctr, Chicago, IL 5353 S. Laramie, Chicago, IL Illinois Financial Ctr, Springfield, IL Burr Ridge Executive, Burr Ridge, IL Lucy and Water St., Saugatuck, MI IRS Data Center, Pontiac, MI Pontiac Place Building, Pontiac, MI Social Security Building, West Branch, MI Federal Building, Redwood Falls, MN Federal Building Courthouse, Minneapolis, MN U.S. Courthouse, Minneapolis, MN Building 201, St. Paul, MN

Custom and Immigration Stat., Baudette, MN Moraine Business Center II, Moraine, $\mathrm{OH}$ Moraine Business Center III, Moraine, $\mathrm{OH}$ Peck Engraving Co., Lakewood, $\mathrm{OH}$ The Esplanade, 2001Butterfield Rd, Downers Grove,IL 1207 Network Centre Blvd, Effingham, IL IRS Data Center, Detroit, MI BP America Building. Cleveland, $\mathrm{OH}$ 
Ace Industrial Dr., Cudahy, WI

FWS Center, Onalaka,WI

700 Regent St, Madison, WI

Region 6

T-Hangar " $G$ ", Grand Island, NE

2610 Ave "Q", Kearney, NE

US Courthouse, Kansas City, MO

Herbert Hoover Library, West Branch, IA

Eisenhower Library, Abilene, KS

U.S. Geological Survey Building, Rolla, MO

2323 Grand Building, Kansas City, MO

\section{Region 7}

USBP Sh Building 13, New Orleans, LA

Open Land - FDA Site, New Orleans, LA

US Border Station, Columbus, NM

USBS, Santa Teresa, NM

Federal Building, Altus, OK

USBS B\&M Bridge, Brownsville, TX

Gateway USBS Building A, Brownsville, TX

Columbia USBS, Laredo, TX

US Border Station, Laredo, TX

USBS Admin Building, Del Rio, TX

BPSH Building 1, Hqtrs, Del Rio, TX

USBS Br Of The Amers, El Paso, TX

U S Border Station, Eagle Pass, TX

Juarez-Lincoln USBS, Laredo, TX

USBS Admin Building, Los Indios, TX

BPSH Building A, Laredo, TX

BPSH Administratn Bd, McAllen, TX

Headquarters Building, Marfa, TX

USBS Paso Del Norte, El Paso, TX

USBS Main Building, El Paso, TX

USBS Good Neighbr Br, El Paso, TX

Unnamed Building, Fort Smith, AR

Unnamed Building, Metairie, LA

Building 27, Houma, LA

Sun Belt Buis Ctr, Albuquerque, NM

SSA District Office, Poteau, OK

US Border Sta -New, Hidalgo, TX

US Border Station, Progreso, TX

US Border Station, Rio Grande City, TX

US Border Station, Presidio, TX

Unnamed Building, Laredo, TX

Vicar Center, San Antonio, TX

USBS Intl Rr Land, Laredo, TX

T \& P Building, Fort Worth, TX

USBS Admin Building, Hidalgo, TX

Chase Plaza SVC CTR, Oklahoma City, OK

USBS Pharr Admin Bld, PHARR,TX

USBS Paso Del Norte, El Paso,TX

USBS Admin Building, Progreso,TX

USBS Admin Building, Roma, TX

GEO H Mahon FB CTHS, Lubbock, TX
Region 8

GSA Parking Lot, Denver, CO

Chief Mtn BS \& Qtrs, Babb, MT

Piegan BS \& Qtrs, Babb, MT

Roosville BS, Eureka, MT

Sweetgrass BS, Sweetgrass, MT

Bdr Patrol Sector HQ, Havre, MT

Turner BS, Turner, MT

Ambrose BS, Ambrose, ND

Dunseith BS, Dunseith, ND

Portal BS, Portal, ND

St John BS, St John, ND

Pembina BS, Pembina, ND

GSA Storage Building, Bismarck, ND

Bdr Patrol Sector HQ, Grand Forks, ND

New Parking Lot, Bismarck, ND

Sunbeam Appl Svc, Salt Lake City, UT

Garage, Cheyenne, WY

Tatum Parking Lot, Helena, MT

Region 9

US Border Station, Lukeville, AZ

BS Old Cus Building, Nogales, AZ

BS Garage, Sasabe, AZ

BS Main Building, Douglas, AZ

Bdr Patl Sector Hqrs, Tucson, AZ

BS Main Building, San Luis, AZ

BS Main Building, Naco, AZ

BS Office Building, Nogales, AZ

Tucson L. E. Site, Tucson, AZ

BS Old Customs Building, Calexico, CA

BS Exist Main Building, San Diego, CA

BS Main Building, Andrade, CA

BS Main Building, Tecate, CA

US Border Patrol Sta, Calexico, CA

Federal Building, Sacramento, CA

Parking Garage, Los Angeles, CA

Motor Pool, San Francisco, CA

1303 Albee Street, Eureka, CA

Building 1, Flagstaff, AZ

NPS Building, Grand Canyon, AZ

Buildings $4 \&$ 5, Flagstaff, AZ

Sorrento Exec Plaza, San Diego, CA

15650 Devonshire Street, Los Angeles, CA

Region 10

Dalton Cache Bor Sta, Haines, AK

Station Building, Tok, AK

Int Ag Motor Pool, Anchorage, AK

Skagway Border Stat, Skagway, AK

US Border Station, Eastport, ID

US Border Sta New, Porthill, ID

Station Building No.1 \& 2, Blaine, WA

Danville Border Sta, Danville, WA

Station \& Quarters, Curlew, WA

Station, Laurier, WA 
Station, Metaline Falls, WA

US Border Station, Oroville, WA

US Border Station, Sumas, WA

Building 601, Walla Walla, WA

Kenneth G. Ward BS, Lynden, WA

US Border Station, Point Roberts, WA

Border Patrol Sect HQ, Blaine, WA

Border Patrol Sect HQ Annex, Blaine, WA

Border Patrol Sect HQ, Spokane, WA

Miuw Facility, Portland, OR

U.S. Courthouse, Portland, OR

USDA Building, Blaine, WA

Operations Building, Moses Lake, WA

Border Patrol Sec HQ Annex, Blaine, WA

\section{Region 11}

FOB 6, Washington DC

White House, Washington DC

Delasalle, Avondale, MD

$1800 \mathrm{G}$ Street NW, Washington DC

Doggett Building, Washington DC
Central Htg Plant Stm., Washington DC

West Htg Plant Stm., Washington DC

U.S. International Tr, Washington DC

1724 F Street NW, Washington DC

Reagan Building FOB, Washington DC

601 4th St, NW, Washington DC

Universal, Washington DC

Penn-Belt Center, Forrestville, MD

9620 Medical Center, Rockville, MD

Manor Business Ctr, Landover, MD

Census Computer Fac., Bowie, MD

5000 Philadelphia Way, Lanham, MD

Mat Land Co Office \& Lab, Glendale Heights, MD

Rockwall Building, Rockville, MD

Herndon Industrial Park, Herndon, VA

7405 \& 7407 Lockport, Lorton, VA

Poplar Run Park Builing 5, Alexandria, VA

Gunston Industrial Park C, Arlington, VA

Arlington Center, Arlington, VA

AV Bryan Sr Courtshe, Alexandria, VA 


\section{National Aeronautics and Space Administration}

Ames Research Center (ARC)

Computational Fluid Dynamics Building

Vertical Gun

3.5 Ft. Wind Tunnel Model Building

12 Ft. Pressure Wind Tunnel

12 Ft. Wind Tunnel Auxiliaries

Propulsion Simulations Calibration Laboratory

Ballistic Range

Flight Support Facility

Model Development Facility

$7 \times 10 \mathrm{Ft}$. Wind Tunnel \#1

$7 \times 10 \mathrm{Ft}$. Wind Tunnel \#2

Model Preparation Facility

Model Assembly

Magnetic Calibration Laboratory

Magnetic Test Laboratory

$14 \mathrm{Ft}$. Transonic Wind Tunnel

$14 \mathrm{Ft}$. Electrical Equipment Building

Fan Blade Shop

Technical Services Shop

$40 \times 80$ Ft. Wind Tunnel

20-G Centrifuge

$80 \times 120 \mathrm{Ft}$. Wind Tunnel

$2 \times 2$ Ft. Transonic Wind Tunnel

Electrical Substation

Electrical Substation North

$6 \times 6 \mathrm{Ft}$. Supersonic Wind Tunnel

Unitary Plan Wind Tunnel Building

$11 \mathrm{Ft}$. Transonic Wind Tunnel

9x7 Ft. Subsonic Wind Tunnel

$8 \times 7$ Ft. Subsonic Wind Tunnel

Unitary Plan Wind Tunnel Auxiliary Building

$3.5 \mathrm{Ft}$. Hypersonic Wind Tunnel

3.5 Ft. Hypersonic Wind Tunnel Auxiliary Building

3.5 Ft. Hypersonic Wind Tunnel Storage Building

Fluid Dynamics Laboratory

Central Computation Facility

Advanced Computation Facility

Thermal Protection Facility

Thermal Protection Boiler

Bioscience Laboratories

Hypervelocity Free Flight Facility

Arc Jet Facility

Life Sciences Research Laboratory

Life Sciences Equipment Facility

Life Sciences Flight Experiments Facility

Airborne Missions/Life Science Facility

Vestibular Research Facility

Vertical Motion Simulator

Vertical Motion Simulator Equipment Facility

Space Projects Facility

Space Sciences Research Laboratory
Model Construction Facility

Aircraft Service Facility

Aircraft Service Facility

Aircraft Service Facility

RSRA Calibration Facility

Aircraft Service Facility

Outside Aerodynamic Research Facility

High Pressure Air Housing

Propane Facility

Program Support Communication Network Facility

Flight Data Complex

Flight Data Facility

Man-Vehicle System Research Facility

Numerical Aeronautics Simulator

High Altitude Aircraft Support Facility

Fluid Mechanics Laboratory

Biomedical Research Laboratory

Human Performance Research Laboratory

Hazardous Material Storage Facility

Automated Sciences Research Facility

NASA Industrial Plant (Downey) and USAF Plant

42, Production Site 1 (Palmdale)

Entire Facilities are Mission Variable

Goddard Space Flight Center (GSFC)

Central Flight Control Range

Instrument Construction/Development Laboratory

Payload Testing Facility

Environmental Testing Laboratory

Network Control Center

Spacecraft Operations Facility

Data Interpretation Laboratory

Spacecraft Systems Development/Integration Facility

EOS/DIS Building

Goddard Geophysical and Astronomical Observatory Area

Jet Propulsion Laboratory (JPL)

Environmental Laboratory

25 Ft. Space Simulator

Spacecraft Assembly Facility

Space Flight Operations Facility

$10 \mathrm{Ft}$. Space Simulator

Space Flight Support

Frequency Standards Laboratory

Earth \& Space Sciences Laboratory

Micro Devices Laboratory 
Johnson Space Center (JSC)

Flight Operations Support

Flight Operations

Jake Garn Simulator and Training

Crew Systems Laboratory

Photographic Technology Laboratory

Central Data Office

Avionics Systems Laboratory

Central Heating \& Cooling Plant

Auxiliary Chiller Facility

Mission/Space Station Control Center

Planetary \& Earth Sciences Laboratory

Space Environment Simulation Laboratory

Mission Simulation Development Facility

Life Sciences Laboratory

Central Computer Facility

Emergency Power Building

Vibration and Acoustic Test Facility

Atmospheric Re-Entry Materials \&

Structures Evaluation Facility

Radiant Heat Facility

Thermochemical Test Area

Kennedy Space Center (KSC)

Hangar L, Life Sciences Support Facility

Hangar AE, Missile Assembly Building

Robot Wash

Manufacturing Building

Launch Complex 39 A \& B

Communication Distribution \& Switching Center

Operations Building

Operations and Checkout Building

Space Station Processing Facility

Hypergol Module Process North

Hypergol Support Building

Payload Spin Test Facility Replacement

Spacecraft Assembly \& Encapsulation Facility

Hypergol Module Process South

Payload Hazardous Service Facility

Vertical Processing Facility

Central Instrumentation Facility

First Wash Building

Orbiter Processing Facility High Bay 3

Orbiter Processing Facility

Launch Control Center

Vehicle Assembly Building Repeater

Component Service Facility

Propellent Laboratory and High Pressure Gas Facility

Program Support Communication

Film Storage

Payload Support Building

Canister Rotation Facility

Ordnance Storage
Langley Research Center (LaRC)

$8 \mathrm{Ft}$. Transonic Pressure Tunnel

University of Virginia and ART Management Office

Building

$30 \times 60 \mathrm{Ft}$. Tunnel

Transonic Dynamic Tunnel

Hydrodynamics Research Facility

Space Environmental Effects Laboratory

$16 \mathrm{Ft}$. Transonic Tunnel.

Subsonic Tunnel Offices

High Speed $7 \times 10 \mathrm{Ft}$. Tunnel

$14 \times 22 \mathrm{Ft}$. Subsonic Tunnel

Central Heating and Steam Generation Plant

Conference Center

Anechoic Noise Facility

Hypersonic Propulsion Facility

High Intensity Noise Research Laboratory

Frequency Converter Building

National Transonic Facility (NTF)

NTF Tunnel Model Storage

Foundry \& Glass Blowing Shop

Drive Control Facility

0.3 Meter Transonic Cryogenic Tunnel

Gas Dynamics/Fluid Mechanics Research Facility

Hypersonic Facilities Complex - West Wing

Hypersonic Facilities Cooling Tower

Hypersonic Facilities Complex - East Wing

Compressor Station

60-Inch M18 Helium Tunnel Facility

Vacuum Pumping station - Gas Dynamics Complex

Atmospheric Sciences/Systems Development

Laboratory

Atmospheric Sciences Laboratory Annex

Unitary Wind Tunnel

$8 \mathrm{Ft}$. High Temperature Tunnel

Central Scientific Computing Facility

Flight Simulation Laboratory

Central Scientific Computing Facility

EOSDIS-DAAC Facility

East Area Compressor Station

Flight Dynamics Drop Model Facility

Structures and Materials Research Laboratory

Lewis Research Center (LeRC)

Engine Research Building

Engine Research Building-West Wing

Engine Research Building-Northwest Wing

Engine Research Building-High Pressure Facility

Engine Research Building-Spray Cooler Building

Engine Research Building-Cooling Tower No. 4

Chemistry Laboratory

Icing Research Tunnel

Icing Research Tunnel-Refrigeration Building 
Icing Research Tunnel-Cooling Tower No. 1

Special Projects Laboratory

Materials Research Laboratory

Materials \& Structures Laboratory

Central Air Equipment Building

Central Air Equipment Building-PSL Cooling Tower No. 3

Central Air Equipment Building-PSL Cooling Tower

Water Pump Building

Central Air Equipment Building-PSL Desiccant Air

Dryer

Central Air Equipment Building-PSL Cooling Tower

No. 6

Instrument Research Laboratory

Engine Research Building Combustion Air Heater

Engine Components Research Laboratory

Materials Processing Laboratory

Basic Materials Laboratory

Aero-Acoustic Propulsion Laboratory

\& Control Room

PSL Heater Building

Electric Power Laboratory

Energy Conversion Laboratory

Space Power Research Laboratory

8 X 6 Ft. Supersonic Wind Tunnel

$8 \mathrm{X} 6 \mathrm{Ft}$. Supersonic Wind Tunnel- Cooling Tower No. 2

$8 \mathrm{X} 6 \mathrm{Ft}$. Supersonic Wind Tunnel-Drive Equipment Building

8 X 6 Ft. Supersonic Wind Tunnel-Air Dryer

Building

$10 \mathrm{X} 10 \mathrm{Ft}$. Supersonic Wind Tunnel (SWT)

$10 \times 10 \mathrm{Ft}$. SWT-Office and Control Building

10 X $10 \mathrm{Ft}$. SWT-2nd Compressor and Drive

Building

10 X $10 \mathrm{Ft}$. SWT-Air Dryer Building

$10 \times 10$ Ft. SWT-Substation "K"

10 X $10 \mathrm{Ft}$. SWT-Main Compressor and Drive

Building

10 X 10 Ft. SWT-Low Pressure Fuel Pump Building

10 X 10 Ft. SWT-High Pressure Fuel Pump Building

10 X 10 Ft. SWT-Cooling Tower No. 5

10 X 10 Ft. SWT-Cooling Tower Water Pump

Building

10 X $10 \mathrm{Ft}$. SWT-Shop Building (\#86)

$10 \times 10 \mathrm{Ft}$. SWT-Exhauster Building

Operations/Integration Building

Marshall Space Flight Center (MSFC)

Microwave Anechoic Chamber

Communications Facility

Photographic Laboratory
SSME - Block II Facility

LIDAR Facility

Power Systems Laboratory

MAST/FSL Simulation Facility

Space Science Labortory

Laboratory \& Office Building

Test Stand Support Building

Test Facility 300

Test Facility 116

Structural Test Facility

Test Facility Terminal Building

Hot Gas Test Facility

Test Control and Service Building

TPTA Refurbishment Facility

Pump and Boiler House

Propulsion and Structural Test Facility

Test \& Data Recording Facility

Space Environmental Effects Laboratory

Air Compressor Building

Materials \& Processes Laboratory

Atmospheric Research Facility

Heat Treatment Facility

Structural Dynamics \& Thermal Vacuum Laboratory

Hydrogen Test Facility

High Pressure Test Facility

Multi-Purpose High Bay Facility

Hydraulic Equipment Development Facility

LH2 Vaporization Facility

High Pressure GN2 Facility ,

Boiler Plant

Computer Facility

Pump House

Advanced Engine Test Facility

Test Support Building

Block House

Boiler House

Helium Compressor Building

Non-Destructive Evaluation Laboratory

Shops \& Neutral Buoyancy Simulator

Productivity Enhancement Facility

Engineering \& Developmental Laboratory

Developmental Processes Laboratory

X-Ray Calibration Facility

Office and Wind Tunnel

Compressed Air Facility

Air Compressor Facility

High Bay Shop Building

Space Station Development Laboratory

Surface Treatment Facility

High Reynolds Number Facility

Low Density Flow Facility

Engine Dynamic Fluid Flow Facility 
Entire Facility is Industrial

Plum Brook Station (PBS)

Entire Facility is Mission Variable

Santa Susana Field Laboratory (SSFL)

Entire Facility is Mission Variable

Tracking Stations

Deep Space Network, Goldstone, CA TDRSS Ground Terminals, White Sands, NM STDN Site, Ponce de Leon, FL
Radar Facility

Machine Shop - Fabrication

Aircraft Projects/Hangar Area

Electronics Support/Storage

Mainland/Island

White Sands Test Facility

Altitude Simulation System (Steam Generator)

Diesel Pad

Boiler Building

Switchgear Building

Altitude Simulation System Building

Steam Generator Support Building

Boiler Building

Water Treatment Building

Treated Water Storage Facility

300 Area Cooling Pond

\section{Panama Canal Commission}

Marine Bureau (159 buildings)

Lock chambers

Electrical towing locomotives

Canal navigational lighting

Computerized marine traffic control

Repair facilities

Related infrastructure

Engineering \& Construction Bureau (257 buildings)

Industrial sector
Tug, locomotive, and dredging-related equipment repair shops

Potable water processing

Communication

Utility services

General Services Bureau (239 buildings)

Vehicle maintenance and repair shops

Fire stations

Sanitation and grounds management facilities

High energy-consuming activities

\section{U.S. Information Agency}

Relay Station, Greenville, North Carolina

Relay Station, Delano, California

Relay Station, Dixon, California (inactive)

Relay Station, Bethany, Ohio

Relay Station, Munich, Germany

Relay Station, Kavala, Greece

Relay Station, Rhodes, Greece
Relay Station, Bangkok, Thailand

Relay Station, Tangier, Morocco

Relay Station, Colombo, Sri Lanka

Relay Station, Botswana

Relay Station, Belize

Relay Station, Philippines 


\section{U.S. Department of Agriculture}

242 Barns

2 Bus Stations

87 Chemical Storage Buildings

8 Engineering Facilities

4 Filling Stations

5 Fire Stations

479 Greenhouses

76 Garages

98 Headhouses

137 Housing Buildings

2 Incinerator Buildings

514 Laboratory Buildings
78 Office Buildings

85 Office/Laboratory Buildings

Chapel

6 Restroom Buildings

215 Sheds

158 Shops

426 Storage Buildings

54 Trailers

Weather Station

2 Waste Treatment Buildings

494 Other Building Types

\section{U.S. Department of Justice}

FBI Headquarters, J. Edgar Hoover Building

FBI Academy, Quantico

FBI Miami

FBI Western Region
FBI West Virginia Complex

Justice Data Center, Washington, DC

Immigration \& Naturalization Service Repeater

Stations - Nationwide

\section{U.S. Department of State}

Main State Complex

Blair House Complex
Beltsville Information Management Center International Chancery Center

\section{National Archives and Records Administration}

National Archives Building, Washington DC, National Archives at College Park, MD

Herbert Hoover Library, West Branch, IA

Harry S. Truman Library, Independence, MO

Dwight D. Eisenhower Library, Abilene, KS

Lyndon B. Johnson Library, Austin, TX
Gerald R. Ford Library, Ann Arbor, MI

Gerald R. Ford Museum, Grand Rapids, MI

Jimmy Carter Library, Atlanta, GA

Ronald Reagan Library, Simi Valley, CA

John Fitzgerald Kennedy Library, Boston, MA

Franklin D. Roosevelt Library, Hyde Park, NY

\section{Social Security Administration}

National Computer Center, Baltimore, MD 


\section{APPENDIX E \\ DEPARTMENT OF ENERGY: EDUCATION, EXTENSION, AND INFORMATION SERVICES}

Energy Efficiency and Renewable Energy Clearinghouse (EREC)

Contact: Pat Rose, (202) 586-9645

Office of Public Affairs

Contact: F. Chester Gray, (202) 586-6827

Industrial Assessment Center (IAC) Program

Contact: Charles J. Glaser, (202) 586-1298

Inventions and Innovation Program (IIP)

Contact: Sandy Glatt, (202) 586-2079

Gas Mileage Guide

Contact: David Greene, (423) 574-5963

National Energy Information Center, Energy Information Administration (NEIC/EIA)

Contact: Sandra Wilkins, (202) 586-1173

Office of Federal Energy Management Programs (FEMP)

Contact: Shelley Fidler, (202) 586-5772

Office of Scientific and Technical Information (OSTI)

Contact: Bill Edmunds, (423) 576-3382

Technical Information Program, National Renewable Energy Laboratory (NREL)

Contact: David Warner, (303) 275-4373

State Energy Program

Contact: Thomas Stapp, (202) 586-2096

Technical Information and Communication Program

Contact: Marilyn Burgess (202) 586-2040

Weatherization Assistance Program

Contact: Gail McKinley, (202) 586-4074 
This page intentionally left blank. 


\section{APPENDIX F \\ FEDERAL INTERAGENCY ENERGY POLICY COMMITTEE \\ (656 COMMITTEE) \\ FY 1998}

Committee Chair

Mr. Dan W. Reicher

Assistant Secretary

Energy Efficiency and Renewable Energy

U.S. Department of Energy, EE-1

Forrestal Building, Room 6C-016

1000 Independence Avenue, SW

Washington, DC 20585

Phone: 202-586-9220

Fax: 202-586-9260

Agriculture

Mr. Pearlie Reed

Assistant Secretary for Administration

U.S. Department of Agriculture

Administration Building, Room $240 \mathrm{~W}$

14th and Independence Avenue, SW

Washington, DC 20250-0103

Phone: 202-720-3590

Fax: 202-720-2191

Commerce

Mr. Scott Gould

Chief Financial Officer and

Deputy Assistant Secretary for Administration

U.S. Department of Commerce

Main Commerce, Room 5830

14th and Constitution Avenue, NW

Washington, DC 20230

Phone: 202-482-4951

Fax: 202-482-3592

Defense

Mr. John Goodman

Deputy Under Secretary of Defense

Industrial Affairs and Installations

3330 Defense Pentagon, Room 3E-1074

Washington, DC 20301-3330

Phone: 703-697-0051

Fax: 703-695-4277

Education

Mr. Gary J. Rasmussen

Director for Management

U.S. Department of Education

600 Independence Avenue, SW, Room 2164

Washington, DC 20202

Phone: 202-401-0470

Fax: 202-401-0485
Environmental Protection Agency

Mr. John C. Chamberlin

Director Office of Administration

and Resources Management

Environmental Protection Agency

Room 1109 West Tower, MS3201

$401 \mathrm{M}$ Street, SW

Washington, DC 20460

Phone: 202-260-8400

Fax: 202-260-8408

General Services Administration

Mr. Robert A. Peck

Commissioner of Public Buildings Service

General Services Administration

Room 6344

18th and F Streets, NW

Washington, DC 20405

Phone: 202-501-1100

Fax: 202-219-2310

Health and Human Services

Mr. John Callahan

Assistant Secretary

for Management and Budget

U.S. Department of Health

and Human Services

Hubert H. Humphrey Building,

Room 416-G

200 Independence Avenue, SW

Washington, DC 20201

Phone: 202-690-6396

Fax: 202-690-5405

Housing and Urban Development

Mr. Willie Gilmore

Deputy Assistant Secretary for Administration

U.S. Department of Housing and

Urban Development

Room 10110

451 7th Street, SW

Washington, DC 20410

Phone: 202-708-0940

Fax: 202-619-8129 
Interior

Mr. Brooks B. Yeager

Acting Assistant Secretary for Policy,

Management and Budget

U.S. Department of the Interior

Mail Stop 6130, Room 6130

1849 C Street, NW

Washington, DC 20240

Phone: 202-208-4203

Fax: 202-208-4561

Justice

Mr. Stephen R. Colgate

Assistant Attorney General

for Administration

U.S. Department of Justice

Room 1111

10th and Constitution Avenue, NW

Washington, DC 20530

Phone: 202-514-3101

Fax: 202-514-1778

Labor

Ms. Patricia W. Lattimore

Acting Assistant Secretary

for Administration and Management

U.S. Department of Labor

Room S-2514

200 Constitution Avenue, NW

Washington, DC 20210

Phone: 202-219-9086

Fax: 202-219-1270

National Aeronautics and

Space Administration

Mr. Jeffrey E. Sutton

Associate Administrator for Management

Systems and Facilities

National Aeronautics and Space Administration

Code J, Room 6W17

300 E Street, SW

Washington, DC 20546-0001

Phone: 202-358-2800

Fax: 202-358-3068

Postal Service

Mr. William Dowling

Vice President, Engineering

U.S. Postal Service

8403 Lee Highway

4th Floor

Merrifield, VA 22082-8101

Phone: 703-280-7001

Fax: 703-280-8401
State

Mr. Patrick S. Kennedy

Assistant Secretary

for Administration

U.S. Department of State

Room 6330

22nd \& C Streets, NW

Washington, DC 20520

Phone: 202-647-1492

Fax: 202-647-1558

Transportation

Ms. Melissa Spillenkothen

Assistant Secretary for Administration

U.S. Department of Transportation

Room 10314

4007 th Street, SW

Washington, DC 20590

Phone: 202-366-2332

Fax: 202-366-9634

Treasury

Ms. Nancy Killefer

Assistant Secretary

for Management/Chief Financial Officer

U.S. Department of the Treasury

Room 2426, Main Treasury Building

1500 Pennsylvania Avenue, NW

Washington, DC 20220

Phone: 202-622-0410

Fax: 202-622-2337

Veterans Affairs

Dr. Thomas L. Garthwaite

Deputy Under Secretary for Health (10A)

U.S. Department of Veterans Affairs

Room 806

810 Vermont Avenue, NW

Washington, DC 20420

Phone: 202-273-5803

Fax: 202-273-7090

Office of Management and Budget

Dr. Kathleen Peroff

Deputy Associate Director

Energy and Science Division

Office of Management and Budget

New Executive Office Building

Room 8001

725 17th Street, NW

Washington, DC 20503

Phone: 202-395-3404

Fax: 202-395-4817 


\title{
APPENDIX G \\ PERSONNEL OF THE DEPARTMENT OF ENERGY'S \\ FEDERAL ENERGY MANAGEMENT PROGRAM
}

\section{FY 1998 Personnel}

\author{
Dan W. Reicher \\ Assistant Secretary, Energy Efficiency and Renewable Energy \\ and Chair, Federal Interagency \\ Energy Policy Committee
}

Federal Energy Management Program Staff:

John Archibald, Director

Executive Secretary, Federal Interagency Energy Policy Committee, Executive Director, Interagency Energy Management Task Force

\author{
Veronica Bellamy \\ Ted Collins \\ Anne Sprunt Crawley \\ Jerry Dion \\ Judy Florance \\ Curtis Framel \\ Mike Fulton \\ Nancy Hapstack \\ Louis Harris \\ Annie Haskins \\ Arun Jhaveri \\ April Johnson \\ Randy Jones \\ Paul King \\ Bill Klebous
}

Rick Klimkos

Katie Kroehle

Helen Krupovich

Will Litner

Dean McCauley

Bob McLaren

Tatiana Strainic Muessel

Pat O'Brien

Vic Petrolati

Will Prue

Ernie Rios

Tanya Sadler

Cheri Sayer

Fred Singleton

Nellie Tibbs 